
ฮั 




\section{MY STUDY WINDOWS.}

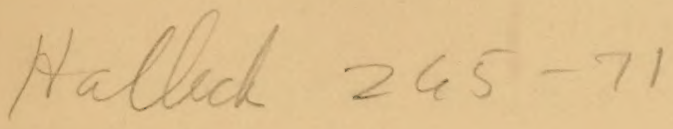

BY

JAMES RUSSELL LOWELL, A. M., PROFESSOR OF BELLES-LETTRES IN HARVARD COLLEGE.

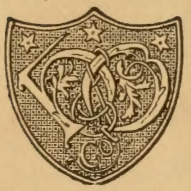

BOSTON :

HOUGHTON, MIFFLIN AND COMPANY. New York: 11 East Seventeenth Street.

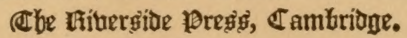
1859. 


$$
\begin{gathered}
P S_{2} 320 \\
\text { A1 } \\
1889
\end{gathered}
$$

Entered according to Act of Congress, in the year 1871,

$$
\text { ¿BY JAMES RUESELL LOWTLL, }
$$

in the Offee of the Libsariar of Congress, at Weshington

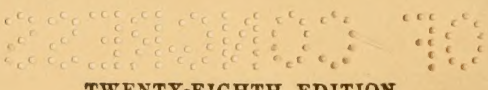

TWENTY-EIGHTH EDITION.

\section{D, Coma, witein}

\section{$27 \mathrm{Je}^{\prime} \mathrm{O}$}




\section{PREFATORY NOTE.}

W ${ }^{\mathrm{Y}}$ former volume of Essays has been so kindily received that I am emboldened to make another and more miscellaneous collection. The papers here gathered have been written at intervals during the last fifteen years, and I knew no way so effectual to rid my mind of them and make ready for a new departure, as this of shutting them between two covers where they can haunt me, at least, no more. I should have preferred a simpler title, but publishers nowadays are inexorable on this point, and I was too mach occupied for happiness of choice. That which I have desperately snatched is meant to imply both the books within and the world without, and perhaps may pass muster in the case of one who has always found his most fruitful study in the open air. 


\section{PROFESSOR F. J. CHILD.}

Mr dear Child, -

You were good enough to like my Essay on Chaucer (about whom you know so much more than I), and I shall accordingly so far presume upon our long friendship as to inscribe the volume containing it with your name.

Always heartily yours,

J. R. LOWELI.

Cambridge, Christmas, 1870. 


\section{O N T E N T S.}

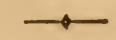

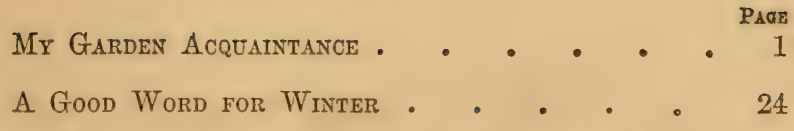
. On a Certain Condescension in Foreigners . • 54 A Great Public Character . • • • . 83 LCarlyle . • • • • • • • • 115 Abraham Lincoln : $\cdot$ • . . . 150 The Life and Letters of James Gates Percival • 178 Thoreau • • • • • . • • • 193

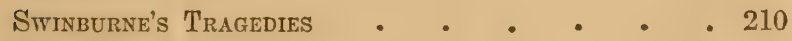
Chaucer . . . . . . . . . 227 Library of Old Authors • • • • • 290 Emerson, the Lecturer. • • • • • - 375 : Pope • • • • • . • • • • 385 



\section{MY GARDEN ACQUAINTANCE.}

ONE of the most delightful books in my father's library was White's Natural History of Selborne. For me it has rather gained in charm with years. I used to read it without knowing the secret of the pleasure 1 found in it, but as I grow older I begin to detect some of the simple expedients of this natural magic. Open the book where you will, it takes you out of doors. In our broiling July weather one can walk out with this genially garrulous Fellow of Oriel and find refreshment instead of fatigue. You have no trouble in keeping abreast of him as he ambles along on his hobby-horse, now pointing to a pretty view, now stopping to watch the motions of a bird or an insect, or to bag a specimen for the Honourable Daines Barrington or Mr. Pennant. In simplicity of . taste and natural refinement he reminds one of Walton ; in tenderness toward what he would have called the brute creation, of Cowper. I do not know whether his descriptions of scenery are good or not, but they have made me familiar with his neighborhood. Since I first read him, I have walked over some of his favorite haunts, but I still see them through his eyes rather than by any recollection of actual and personal vision. The book has also the delightfulness of absolute leisure. Mr. White seems never to have had any harder work to do than to study the habits of his feathered fellow-townsfolk, or to watch the ripening of his peaches on the wall. His volumes are the journal of Adam in Paradise, 


\section{"Annihilating all that's made \\ To a green thought in a green shade."}

It is positive rest only to look into that garden of his It is vastly better than to

\section{"See great Diocletian walk}

In the Salonian garden's noble shade,"

for thither ambassadors intrude to bring with them the noises of Rome, while here the world has no entrance. No rumor of the revolt of the American Colonies seems to have reached him. "The natural term of an hog's life" has more interest for him than that of an empire. Burgoyne may surrender and welcome; of what consequence is that compared with the fact that we can explain the odd tumbling of rooks in the air by their turning over "to scratch themselves with one claw"? All the couriers in Europe spurring rowcl-deep make no stir in Mr. White's little Chartreuse; but the arrival of the housemartin a day earlier or later than last year is a piece of news worth sending express to all his correspondents.

Another secret charm of this book is its inadvertent humor, so much the more delicious because unsuspected by the author. How pleasant is his innocent vanity in adding to the list of the British, and still more of the Selbornian, fauna! I believe he would gladly have consented to be eaten by a tiger or a crocodile, if by that means the occasional presence within the parish limits of either of these anthropophagous brutes could have been established. He brags of no fine society, but is plainly a little elated by "having considerable acquaintance with a tame brown owl." Most of us have known our share of owls, but few can boast of intimacy with a feathered one. The great events of Mr. White's life, too, have that disproportionate importance which is always humorous. To think of his hands having actually been thought worthy (as neither Willoughby's nor Ray's were) to hold 
a stilted plover, the Charadrius himantopus, with no back toc, and therefore "liable, in speculation, to perpetual vacillations"! I wonder, by the way, if metaphysicians have no hind toes. In 1770 he makes the acquaintance in Sussex of "an old family tortoise," which had then been domesticated for thirty years. It is clear that he fell in love with it at first sight. We have no means of tracing the growth of his passion; but in 1780 we find him eloping with its object in a post-chaise. "The rattle and hurry of the journey so perfectly roused it that, when I turned it out in a border, it walked twice down to the bottom of my garden." It reads like a Court Journal : "Yesterday morning H. R. H. the Princess Alice took an airing of half an hour on the terrace of Windsor Castle." This tortoise might have been a member of the Royal Society, if he could have condescended to so ignoble an ambition. It had but just been discovered that a surface inclined at a certain angle with the plane of the horizon took more of the sun's rays. The tortoise had always known this (though he unostentatiously made no parade of it), and used accordingly to tilt himself up against the garden-wall in the autumn. He seems to have been more of a philosopher than even Mr. White himself, caring for nothing but to get under a cabbage-leaf when it rained, or the sun was too hot, and to bury himself alive before frost, - a four-footed Diogenes, who carried his tub on his back.

There are moods in which this kind of history is infinitely refreshing. These creatures whom we affect to look down upon as the drudges of instinct are members of a commonwealth whose constitution rests on immorable bases. Never any need of reconstruction there! They never dream of settling it by rote that eight hours are equal to ten, or that one creature is as clever as another and no more. They do not use their poor wits in 
regulating God's clocks, nor think they cannot go astray so long as they carry their guide-board about with them, - a delusion we often practise upon ourselves with our high and mighty reason, that admirable finger-post which points every way and always right. It is good for us now and then to converse with a world like Mr. White's, where Man is the least important of animals. But one who, like me, has always lived in the country and always on the same spot, is drawn to his book by other occult sympathies. Dowe not share his indignation at that stupid Martin who had graduated his thermometer no lower than $4^{\circ}$ above zero of Fahrenheit, so that in the coldest weather ever known the mercury basely absconded into the bulb, and left us to see the victory slip through our fingers just as they were closing upon it? No man, I suspect, ever lived long in the country without being bitten by these metearological ambitions. He likes to be hotter and colder, to have been more decply snowed up, to have more trees and larger blown down than his neighbors. With us descendants of the Puritans especially, these weather-competitions supply the abnegated excitement of the race-caurse. Men learn to value thermometers of the true imaginative temperament, capable of prodigious elations and corresponding dejections. The other day (5th July) I marked $98^{\circ}$ in the shade, my highwater mark, higher by one degree than I had ever seen it before. I happened to meet a neighhor ; as we mopped our brows at each other, he told me that he had just cleared $100^{\circ}$, and I went home a beaten man. I had not felt the heat before, save as a beautiful exaggeration of sunshine; but now it oppressed me with the prosaic vulgarity of an oven. What had been poetic intensity became all at once rhetorical hyperbole. I might suspect his thermometer (as indeed I did, for we Harvard men are apt to think ill of any graduation but our own); but 
it was a poor consolation. The fact remained that his herald Mercury, standing a-tiptoe, could look down on mine. I seem to glimpse something of this familiar weakness in Mr. White. He, too, has shared in these mercurial triumphs and defeats. Nor do I doubt that he had a true country-gentleman's interest in the weathercock ; that his first question on coming down of a morning was, like Barabas's,

"Into what quarter peers my halcyon's bill?"

It is an innocent and healthful employment of the mind, distracting one from too continual study of himself, and leading him to dwell rather upon the indigestions of the elements than his own. "Did the wind back round, or go about with the sun?" is a rational question that bears not remotely on the making of hay and the prosperity of crops. I have little doubt that the regulated obserration of the vane in many different places, and the interchange of results by telegraph, would put the weather, as it were, in our power, by betraying its ambushes before it is ready to give the assault. At first sight, nothing seems more drolly trivial than the lives of those whose single achievement is to record the wind and the temperature three times a day. Yet such men are doubtless sent into the world for this special end, and perhaps there is no kind of accurate observation, whatever its object, that has not its final use and value for some one or other. It is even to be hoped that the speculations of our newspaper editors and their myriad correspondents upon the signs of the political atmosphere may also fill their appointed place in a well-regulated universe, if it be only that of supplying so many more jack-o'-lanterns to the future historian. Nay, the observations on finance of an M. C. whose sole knowledge of the subject has been derived from a lifelong success in getting a living out of the public without paying any 
equivaient therefor, will perhaps be of interest hereafter to some explorer of our cloaca maxima, whenever it is cleansed.

For many years I have been in the habit of noting down some of the leading events of my embowered solitude, such as the coming of certain birds and the like, a kind of memoires pour servir, after the fashion of White, rather than properly digested natural history. I thought it not impossible that a fow simple stories of my winged acquaintances might be found entertaining by persons of kindred taste.

There is a common notion that animals are better meteorologists than men, and I have little doubt that in immediate weather-wisdom they have the advantage of our sophisticated senses (though I suspect a sailor or shepherd would be their match), but I have seen nothing that leads me to belicve their minds capable of erecting the horoscope of a whole season, and letting us know beforehand whether the winter will be severe or the summer rainless. I more than suspect that the elerk of the weather himself does not always know very long in advance whether he is to draw an order for hot or cold, dry or moist, and the musquash is scarce likely to be wiser. I have noted but two days' difference in the coming of the song-sparrow between a very early and a very backward spring. This very year I saw the limnets at work thatching, just before a snow-storm which covered the ground several inches deep for a number of days. They struck work and left us for a while, no doubt in search of food. Birds frequently perish from sudden changes in our whimsical spring weather of which they had no foreboding. More than thirty years ago, a cherry-tree, then in full bloom, near my window, was covered with humming-birds benumbed by a fill of mingled rain and snow, which probably killed many of 
them. It should seem that their coming was dated by the height of the sun, which betrays them into unthrifty matrimony ;

"So nature pricketh hem in their corages";

but their going is another matter. The chimney-swallows leave us early, for example, apparently so soon as their latest fledglings are firm enough of wing to attempt the long rowing-match that is before them. On the other hand, the wild-geese probably do not leave the North till they are frozen out, for I have heard their bugles sounding southward so late as the middle of December. What may be called local migrations are doubtless dictated by the chances of food. I have once been visited by large flights of cross-bills ; and whenever the snow lies long and deep on the ground, a flock of cedar-birds comes in midwinter to eat the berries on my hawthorns. I have never been quite able to fathom the local, or rather geographical partialities of birds. Never before this summer (1870) have the king-birds, handsomest of flycatchers, built in my orchard; though I always know where to find them within half a mile. The rose-breasted grosbeak has been a familiar bird in Brookline (three miles away), yet I never saw one here till last July, when I found a female busy among my raspberries and surprisingly bold. I hope she was prospecting with a view to settlement in our garden. She scemed, on the whole, to think well of my fruit, and I would gladly plant another bed if it would help to win over so delightful a neighbor.

The return of the robin is commonly announced by the newspapers, like that of eminent or notorious people to a watering-place, as the first authentic notification of spring. And such his appearance in the orchard and garden undoubtedly is. But, in spite of his name of migratory thrush, he stays with us all winter, and I 
have seen him when the thermometer marked 15 degrees below zero of Fahrenheit, armed impregnably within, like Emerson's Titmouse, and as cheerful as he. The robin has a bad reputation among people who do not value themselves less for being fond of cherries. There is, I admit, a spice of vulgarity in him, and his song is rather of the Bloomfield sort, too largely ballasted with prose. His ethics are of the Poor Richard school, and the main chance which calls forth all his energy is altogether of the belly. He never has those fine intervals of lunacy into which his cousins, the catbird and the mavis, are apt to fall. But for a' that and twice as muckle 's a' that, I would not exchange him for all the cherries that ever came out of Asia Minor. With whatever faults, he has not wholly forfeited that superiority which belongs to the children of nature. He has a finer taste in fruit than could be distilled from many successive committees of the Horticultural Society, and he eats with a relishing gulp not inferior to Dr. Johnson's. He feels and freely exercises his right of eminent domain. His is the earliest mess of green peas; his all the mulberries I had fancied mine. But if he get also the lion's share of the raspherries, he is a great planter, and sows those wild ones in the woods, that solace the pedestrian and give a momentary calm even to the jaded victims of the White Hills. He keeps a strict eye over one's fruit, and knows to a shade of purple when your grapes have cooked long enough in the sun. During the severe drought a few years ago, the robins wholly vanished from my garden. I neither saw nor heard one for three weeks. Mean-while a small foreign grape-vine, rather shy of bearing, seemed to find the dusty air congenial, and, dreaming perhaps of its sweet Argos across the sea, decked itself with a score or so of fair bunches. I watched them from day to day till they should have secreted sugar 
ennugh from the sunbeams, and at last made up my mind that I would celebrate my vintage the next morning. But the robins too had somehow kept note of them. They must have sent out spies, as did the Jews into the promised land, before I was stirring. When I went with my basket, at least a dozen of these winged vintagers bustled out from among the leaves, and alighting on the nearest trees interchanged some shrill remarks about me of a derogatory nature. They had fairly sacked the vine. Not Wellington's veterans made cleaner work of a Spanish town; not Federals or Confederates were ever more impartial in the confiscation of neutral chickens. I was keeping my grapes a secret to surprise the fair Fidele with, but the robins made them a profounder secret to her than I had meant. The tattered remnant of a single bunch was all my harvesthome. How paltry it looked at the bottom of my basket, - as if a humming-bird had laid her egg in an eagle's nest! I could not help laughing; and the robins seemed to join heartily in the merriment. There was a native grape-vine close by, blue with its less refined abundance, but my cunning thieves preferred the foreign flavor. Could I tax them with want of taste?

The robins are not good solo singers, but their chorus, as, like primitive fire-worshippers, they hail the return of light and warmth to the world, is umrivalled. There are a hundred singing like one. They are noisy enough then, and sing, as poets should, with no afterthought. But when they come after cherries to the tree near my window, they muffle their voices, and their faint pip, pip, pop! sounds far away at the bottom of the garden, where they know I shall not suspect them of robbing the great black-walnut of its bitter-rinded store.*

* The screech-owl, whose cry, despite his ill name, is one of the sweetest sounds in nature, softens his voice in the same way with the most beguiling mockery of distance. 
They are feathered Pecksniffs, to be sure, but then how brightly their breasts, that look rather shabby in the sunlight, shine in a rainy day against the dark green of the fringe-tree! After they have pinched and shaken all the life out of an earthworm, as Italian cooks pound all the spirit out of a steak, and then gulped him, they stand up in honest self-confidence, expand their red waistcoats with the virtuous air of a lobby member, and outface you with an eye that calmly challenges inquiry. "Do $I$ look like a bird that knows the flavor of raw vermin? I throw myself upon a jury of my peers. Ask any robin if he ever ate anything less ascetic than the frugal berry of the juniper, and he will answer that his vow forbids him." Can such an open bosom cover such depravity? Alas, yes! I have no doubt his breast was redder at that very moment with the blood of my raspberries. On the whole, he is a doubtful friend in the garden. He makes his dessert of all kinds of berries, and is not averse from early pears. But when we remember how omnivorous he is, eating his own weight in an incredibly short time, and that Nature seems exhanstless in her invention of new insects hostile to vegetation, perhnps we may reckon that he does more good than harm. For my own part, I would rather have his cheerfulness and kind neighborhood than many berries.

For his cousin, the catbird, I have a still warmer regard. Always a good singer, he sometimes nearly equals the brown thrush, and has the merit of keeping up his music later in the evening than any bird of my familiar acquaintance. Ever since I can remember, a pair of them have built in a gigantic syringa, near our front door, and I have known the male to sing almost uninterruptedly during the evenings of early summer till twilight duskened into dark. They differ greatly in vocal talent, but all have a delightful way of crooning 
over, and, as it were, rehearsing their song in an undertone, which makes their nearness always unobtrusive. Thongh there is the most trustworthy witness to the imitative propensity of this bird, I have only once, during an intimacy of more than forty years, heard him indulge it. In that case, the imitation was by no means so close as to deceive, but a free reproduction of the notes of some other birds, especially of the oriole, as a kind of variation in his own song. The catbird is as shy as the robin is vulgarly familiar. Only when his rest or his fledglings are approached does he become noisy and almost aggressive. I have known him to station his young in a thick cornel-bush on the edge of the raspberry-bed, after the fruit began to ripen, and feed them there for a week or more. In such cases he shows none of that conscious guilt which makes the robin contemptible. On the contrary, he will maintain his post in the thicket, and sharply scold the intruder who ventures to steal his berries. After all, his claim is only for tithes, while the robin will bag your entire crop if he get a chance.

Dr. Watts's statement that " birds in their little nests agree," like too many others intended to form the infant mind, is very far from being true. On the contrary, the most peaceful relation of the different species to each other is that of armed neutrality. They are very jealous of neighbors. A few years ago, I was much interested in the housebuilding of a pair of summer yellow-birds. They had chosen a very pretty site near the top of a tall white lilac, within easy eye-shot of a chamber window. A very pleasant thing it was to see their little home growing with mutual help, to watch their industrious skill interrupted only by little flirts and snatches of endearment, frugally cut short by the common-sense of the tiny housewife. They had brought their work 
nearly to an end, and had already begun to line it with fern-down, the gathering of which demanded more distant journeys and longer absences. But, alas! the syringa, immemorial manor of the catbirds, was not more than twenty feet away, and these "giddy neighbors " had, as it appeared, been all along jealously watchful, though silent, witnesses of what they deemed an intrusion of squatters. No sooner were the pretty mates fairly gone for a new load of lining, than

"To their unguarded nest these weasel Scots

Came stealing."

Silently they flew back and forth, each giving a vengeful dab at the nest in passing. They did not fall-to and deliberately destroy it, for they might have been caught at their mischief. As it was, whenever the yellowbirds came back, their enemies were hidden in their own sight-proof bush. Several times their unconscious victims repaired damages, but at length, after counsel taken together, they gave it up. Perhaps, like other unlettered folk, they came to the conclusion that the Devil was in it, and yielded to the invisible persecutions of witcheraft.

The robins, by constant attacks and annoyances, have succeeded in driving off the blue-jays who used to build in our pines, their gay colors and quaint noisy ways making them welcome and amusing neighbors. I once had the chance of doing a kindness to a household of them, which they received with very friendly condeseension. I had had my eye for some tinso upon a nest, and was puzzled by a constant fluttering of what seemed full-grown wings in it whenever I drew nigh. At last I climbed the tree, in spite of angry protests from the old birds against my intrusion. The mystery had a very simple solution. In building the nest, a long piece ef packthread had been somewhat loosely woven in. 
Three of the young had contrived to entangle themselves in it, and had become full-grown without being alle to launch thenselves upon the air. One was unharmed; another had so tightly twisted the cord about its shank that one foot was curled up and seemed paralyzed; the third, in its struggles to escape, had sawn through the flesh of the thigh and so much harmed itself that I thought it humane to put an end to its misery. When I took out my knife to eut their hempen bonds, the heads of the family seemed to divine my friendly intent. Suddenly ceasing their cries and threats, they perched quietly within reach of my hand, and watched me in my work of manumission. This, owing to the fluttering terror of the prisoners, was an affair of some delicacy; but erelong I was rewarded by seeing one of them fly away to a neighboring tree, while the cripple, making a parachute of his wings, came lightly to the ground, and hopped off as well as he could with one leg, obsequiously waited on by his elders. A week later I had the satisfuction of meeting him in the pinewalk, in good spirits, and already so far recovered as to be able to balance himself with the lame foot. I have no doubt that in his old age he accounted for his lameness by some handsome story of a wound receired at the famous Battle of the Pines, when our tribe, overcome by numbers, was driven from its ancient campingground. Of late year's the jays have visited us only at intervals; and in winter their bright plumage, set off by the snow, and their cheerful cry, are especially welcome. They would hare furnished Esop with a fable, for the feathered crest in which they seem to take so much satisfaction is often their fatal suare. Country boys make a hole with their finger in the snow-crust just large enough to admit the jay's head, and, hollowing it out somewhat beneath, bait it with a fow kernels 
of corn. The crest slips easily into the trap, but refuses to be pulled out again, and he who cane to feast remains a prey.

Twice have the crow-blackbirds attempted a settlement in my pines, and twice have the robins, who claim a right of pre-emption, so successfully played the part of border-ruffians as to drive them away, - to my great regret, for they are the best substitute we have for rooks. At Shady Hill (now, alas! empty of its so longlored household) they build by hundreds, and nothing can be more cheery than their creaking clatter (like a convention of old-fashioned tavern-signs) as they gather at evening to debate in mass meeting their windy politics, or to gossip at their tent-doors over the events of the day. Their port is grave, and their stalk across the turf as martial as that of a second-rate ghost in Hamlet. They never meddled with my corn, so far as I could discover:

For a few rears I had crows, but their nests are an irresistible bait for boys, and their settlement was broken up. They grew so wonted as to throw off a great part of their shyness, and to tolerate my near approach. One very hot day I stood for some time within twenty feet of a mother and three children, who sat on an elm bongh over my head, gasping in the sultry air, and holding their wings half-spread for coolness. All birds during the pairing season become more or less sentimental, and murmur soft nothings in a tone very unlike the grinding-organ repetition and loudness of their habitual song. The crow is very comical as a lover, and to hear him trying to soften his croak to the proper Saint Preux standard, has something the effect of a Mississippi boatman quoting Tennyson. Yet there are ferw things to my ear more melodious than his caw of a clear winter morning as it drops to you filtered through five hundred 
fathoms of crisp blue air. The hostility of all smaller birds makes the moral character of the crow, for all his deaconlike demeanor and garb, somewhat questionable. He could nerer sally forth without insult. The golden robins, especially, would chase him as far as I could follow with my eye, making him duck clumsily to avoid their importunate bills. I do not believe, however, that he robbed any nests hereabouts, for the refuse of the gas-works, which, in our free-and-easy community, is allowed to poison the river, supplied him with dead alewives in abundance. I used to watch him making his periodical visits to the salt-marshes and coming back with a fish in his beak to his young savages, who, no doubt, like it in that condition which makes it savory to the Kanakas and other corvine races of men.

Orioles are in great plenty with me. I have seen seven males flashing about the garden at once. A merry crew of them swing their hammocks from the pendulous boughs. During one of these latter years, when the canker-worms stripped our elms as bare as winter, these birds went to the trouble of rebuilding their unroofed nests, and chose for the purpose trees which are safe from those swarming vandals, such as the ash and the button-wood. One year a pair (disturbed, I suppose, elsewhere) built a second nest in an elm, within a few yards of the house. My friend, Edward E. Hale, told me once that the oriole rejected from his web all strands of brilliant color, and I thought it a striking example of that instinct of concealment noticeable in many birds, though it should seem in this instance that the nest was amply protected by its position from all marauder's but owls and squirrels. Last year, however, I had the fullest proof that Mr. Hale was mistaken. A pair of orioles built on the lowest trailer of a weeping elm, which hung within ten feet of our drawing-room 
window, and so low that I could reach it from the ground. The nest was wholly woven and felted with ravellings of woollen carpet in wheh scarlet predominated. Would the same thing have happened in the woods? Or did the nearness of a human dwelling perhaps give the birds a greater fecling of security? They are very bold, by the way, in quest of cordage, and I have often watched them stripping the fibrous bark from a honeysuckle growing over the very door. But, indeed, all my birds look upon me as if I were a mere tenant at will, and they were landlords. With shame I confess it, I have been bullied eren by a humming-bird. This spring, as I was cleansing a pear-tree of its lichens, one of these little zigzagging blurs came purring toward me, conching his long bill like a lance, his throat sparkling with angry fire, to warn me off from a Missouri-currant whose honey he was sipping. And many a time he has drisen me out of a flower-bed. This summer, by the way, a pair of these winged emeralds fastened their mossy acorn-cup upon a bough of the same elm which the orioles had enlivened the year before. We watched all their proceedings from the window through an opera-glass, and saw their two nestlings grow from black needles with a tuft of down at the lower end, till they whirled away on their first short experimental flights. They became strong of wing in a surprisingly short time, and I never saw them or the male bird after, though the female was regular as usual in her visits to our petunias and verbenas. I do not think it ground enough for a gencralization, but in the many times when I watched the old birds feeding their young, the mother aiways alighted, while the father as uniformly remained upon the wing.

The bobolinks are generally chance visitors, tinkling through the garden in blossoming-time, but this year, 
owing to the long rains early in the season, their favorite meadows were flooded, and they were driven to the upland. So I had a pair of them domiciled in my grassfield. The male used to perch in an apple-tree, then in full bloom, and, while I stood perfectly still close by, he would eircle away, quivering round the entire field of five acres, with no break in his song, and settle down again among the blossoms, to be hurried away almost immediately by a new rapture of music. He had the volubility of an Italian charlatan at a fair, and, like him, appeared to be proclaiming the merits of some quack remedy. Opodeldoc-opodeldoc-try-Doctor-Lincoln's-opodeldoc! he seemed to repeat over and over again, with a rapidity that would have distanced the deftest-tongued Figaro that ever rattled. I remember Count Gurowski saying once, with that easy superiority of knowledge about this country which is the monopoly of foreigners, that we had no singing-birds! Well, well, Mr. Hepworth Dixon has found the typical America in Oneida and Salt Lake City. Of course, an intelligent European is the best judge of these matters. The truth is there are more singing-lirds in Europe because there are fewer forests. These songsters love the neighborhood of man because hawks and owls are rarer, while their own food is more abundant. Most people seem to think, the more trees, the more birds. Even Chateaubriand, who first tried the primitive-forest-cure, and whose description of the wilderness in its imaginative effects is unmatched, fancies the "people of the air singing their hymns to him." So far as my own observation goes, the farther one penetrates the sombre solitudes of the roods, the more seldom does he hear the voice of any singing-bird. In spite of Châteaubriand's minuteness of detail, in spite of that marvellons reverberation of the decrepit tree falling of its own weight, which he was the first to 
notice, I cannot help doubting whether he made his way very deep into the wilderness. At any rate, in a letter to Fontanes, written in 1804, he speaks of mes chevanx paissunt à quelque distance. To be sure Châteaubriand was apt to mount the high horse, and this may have been but an afterthought of the grand seigneur, but certainly one would not make much headway on horseback toward the druid fastnesses of the primæval pine.

The bobolinks build in considerable numbers in a mendow within a quarter of a mile of us. A houseless lane passes through the midst of their camp, and in clear westerly weather, at the right season, one may hear a score of them singing at once. When they are breeding, if I chance to pass, one of the male birds always accompanies me like a constable, flitting from post to post of the rail-fence, with a short note of reproof continually repented, till I am fairly out of the neighborhood. Then he will swing aray into the air and run down the wind, gurgling musie withont stint over the unheeding tussocks of meadow-grass and dark clumps of bulrushes that mark his domain.

We have no hird whose song will match the nightingale's in compass, none whose note is so rich as that of the European blackhird; but for mere rapture I have never heard the bobolink's rival. But his operaseason is a short one. The ground and tree sparrows are our most constant performers. It is now late in August, and one of the latter sings erery day and all day long in the garden. Till within a fortnight, a pair of indigo-birds would keep up their lively duo for an hour together. While I write, I hear an oriole gay as in June, and the plaintive may-be of the goldfinch tells me he is stealing my lettuce-seeds. I know not what the experience of others may have been, but the only bird I have ever heard sing in the night has been the 
chip-bird. I should say he sang about as often during the darkness as cocks crow. One can hardly help fancying that he sings in his dreams.

"Father of light, what sunnie seed,

What glance of day hast thou confined

Into this bird? 'To all the breed

This busie ray thou hast assigned;

Their magnetism works all night,

And dreams of Paradise and light."

On second thought, I remember to have heard the cuckoo strike the hours nearly all night with the regularity of a Swiss clock.

The dead limbs of our elns, which I spare to that end, bring us the flicker every surnmer, and almost daily I hear his wild scream and laugh close at hand, himself invisible. He is a shy bird, but a few days ago I had the satisfaction of studying him through the blinds as he sat on a tree within a few feet of me. Seen so near and at rest, he makes good his claim to the title of pigeon-woolpecker. Lumberers have a notion that he is harmful to timber, digging little holes through the bark to encourage the settlement of insects. The regular rings of such perforations which one may see in almost any apple-orchard seem to give some probability to this theory. Almost every season a solitary quail visits us, and, unseen among the currant-bushes, calls Bob White, Bob White, as if he were playing at hide-andseek with that imaginary being. A rarer visitant is the turtle-dove, whose pleasant coo (something like the muffled crow of a cock from a coop covered with snow) I have sometimes heard, and whom I once had the good luck to see close by me in the mulberry-tree. The wildpigeon, once numerous, I have not seen for many years.* Of savage birds, a hen-hawk now and then quarters himself upon us for a few days, sitting sluggish in a tree

* They made their appearance again this summer (1870). 
after a surfeit of poultry. One of them once offered me a near shot from my study-window one drizzly day for several hours. But it was Sunday, and I gave him the benefit of its gracions truce of God.

Certain birds have disappeared from our neighborhood within my memory. I remember when the whippoorwill could be heard in Swcet Auburn. The night-hawk, once common, is now rare. The brown thrush has moved farther up country. For years I have not seen or heard any of the larger owls, whose hooting was one of my boyish terrors. The cliff-swallow, strange emigrant, that eastrard takes his way, has come and gone again in my time. The bank-swallows, wellnigh immumerable during my boyhood, no longer frequent the crumbly cliff of the gravel-pit by the river. The barn-swallows, which once swarmed in our barn, flishing through the dusty sumstreaks of the mow, have been gone these many years. My father would lead me out to see them gather on the roof, and take comnsel before their yearly migration, as Mr. White used to see them at Selborne. Eheu, fugaces! Thank fortume, the swift still glues his nest, and rolls his distant thunders night and day in the wide-throated chimneys, still sprinkles the evening air with his merry twittering. The populous heronry in Fresh Pond meadows has been wellnigh broken up, but still a pair or twe haunt the old home, as the gypsies of Ellangowan their ruined huts, and every crening fly over us riverwards, clearing their throats with a hoarse hawk as they go, and, in cloudy weather, scarce higher than the tops of the chimneys. Sometimes I have known one to alight in one of our trees, though for what purpose I never could divine. Kingfishers have sometimes puzzled me in the same way, perched at high noon in a pine, springing their watchman's rattle when they flitted away from my curiosity, and seeming to shove their top-heavy heads along as a man does a wheelbarrow. 
Some birds have left us, I suppose, because the country is growing less wild. I once found a summer duck's nest within quarter of a mile of our house, but such a trouvaille would be impossible now as Kidd's treasure. And yet the mere taming of the neighborhood does not quite satisfy me as an explanation. 'Twenty years ago, on my way to bathe in the river, I saw every day a brace of woodcock, on the miry edge of a spring within a few rods of a house, and constantly visited by thirsty cows. There was no growth of any kind to conceal them, and yet these ordinarily shy birds were almost as indifferent to my passing as common poultry would have been. Since bird-nesting has become scientific, and dignified itself as oölogy, that, no doubt, is partly to blame for some of our losses. But some old friends are constant. Wilson's thrush comes every year to remind me of that most poetic of omithologists. He flits before me through the pinewalk like the very genius of solitude. A pair of pewees have built immemorially on a jutting brick in the arched entrance to the ice-house. Always on the same brick, and never more than a single pair, though two broods of five each are raised there every summer. How do they settle their claim to the homestead? By what right of primogeniture? Once the children of a man employed about the place oölogized the nest, and the pewees left us for a year or two. I felt towards those boys as the messmates of the Ancient Mariner did towards him after he had shot the albatross. But the pewees came back at last, and one of them is now on his wonted perch, so near my window that I can hear the click of his bill as he snaps a fly on the wing with the unerring precision a stately Trasteverina shows in the capture of her smaller deer. The pewee is the first bird to pipe up in the morning; and, during the early summer he preludes his matutinal ejaculation of pewee with a slender whistle. 
unheard at any other time. He saddens with the season, and, as summer declines, he changes his note to eheu, pewee! as if in lamentation. Had he been an Italian bird, Ovid would have had a plaintive tale to tell about him. $\mathrm{He}$ is so familiar as often to pursue a fly through the open window into my library.

There is something inexpressibly dear to me in these old friendships of a lifetime. There is scarce a tree of mine but has had, at some time or other, a happy homestead among its boughs, to which I cannot say,

\section{"Many light hearts and wings,}

Which now be dend, lodged in thy living bowers."

My walk under the pines would lose half its summer charm were I to miss that shy anchorite, the Wilson's thrush, nor hear in haying-time the metallic ring of his song, that justifies his rustic name of scythe-whet. I protect my game as jealously as an English squire. If anybody had oülogized a certain cuckoo's nest I know of (I have a pair in my garden every year), it would have left me a sore place in my mind for weeks. I love to bring these aborigines back to the mansuetude they showed to the early voyagers, and before (forgive the involuntary pun) they had grown accustomed to man and knew his sarage ways. And they repay your kinduess with a swect familiarity too delicate ever to breed contempt. I have made a Penn-treaty with them, preferring that to the Puritan way with the natives, which converted them to a little Hebraism and a great deal of Medford rum. If they will not come near enough to me (as most of them will), I bring them close with an opera-glass, - a much better weapon than a gun. I would not, if I could, convert them from their pretty pagan ways. The only one I sometimes have savage doubts about is the red squirrel. I think he oölogizes. I know he eats cherries (we counter five of them at one 
time in a single tree, the stones pattering down like the sparse hail that preludes a storm), and that he gnaws off the small end of pears to get at the sceds. He steals the corn from under the noses of my poultry. But what would you have? He will come down upon the limb of the tree I am lying under till he is within a yard of me. $\mathrm{He}$ and his mate will scurry up and down the great blackwalnut for my diversion, chattering like monkeys. Can I sign his death-warrant who has tolerated me about his grounds so long? Not I. Let them steal, and welcome. I am sure I should, had I had the same bringing up and the same temptation. As for the birds, I do not believe there is one of them but does more good than harm; and of how many featherless bipeds can this be said? 


\section{A GOOD WORD FOR WINTER.}

"T TEN scarcely know how beautiful fire is," says

1 I Shelley; and I am apt to think there are a good many other things concerning which their knowledge might be largely increased without becoming burdensome. Nor are they altogether reluctant to be taught, - not so reluctant, perhaps, as unable, - and education is sure to find one fulcrum ready to her hand by which to get a purchase on them. For most of us, I have noticed, are not without an amiable willingness to assist at any spectacle or entertaimment (loosely so called) for which no fee is charged at the door. If special tickets are sent us, another element of pleasure is added in a sense of privilege and pre-eminence (pitiably scarce in a democracy) so decply rooted in human nature that I have secn people take a strange satisfaction in being near of kin to the mute chief personage in a funcral. It gave them a moment's advantage over the rest of us whose grief was rated at a lower place in the procession. But the words "admission free " at the bottom of a handbill, though holding out no bait of inequality, have yet a singular charm for many minds, especially in the country. There is something touching in the constancy with which men attend free lectures, and in the honest patience with which they listen to them. He who pays may yawn or shift testily in his seat, or even go out with an awful reverberation of criticism, for he has bought the right to do any or all of these and paid for it. But gra- 
tuitous hearers are anæsthetized to suffering by a sense of virtue. They are performing perhaps the noblest, as it is one of the most difficult, of human functions in getting Something (no matter how small) for Nothing. They are not pestered by the awful duty of securing their money's worth. They are wasting time, to do which elegantly and without lassitude is the highest achievement of civilization. If they are cheated, it is, at worst, only of a superfluous hour which was rotting on their hands. Not only is mere amusement made more piquant, but instruction more palatable, by this universally relished sauce of gratuity. And if the philosophic observer finds an object of agreeable contemplation in the audience, as they listen to a discourse on the probability of making missionaries go down better with the Feejee-Islanders by balancing the hymn-book in one pocket with a bottle of Worcestershire in the other, or to a plea for arming the female gorilla with the ballot, he also takes a friendly interest in the lecturer, and admires the wise economy of Nature who thus contrives an ample field of honest labor for her bores. Even when the insidious hat is passed round after one of these eleemosynary feasts, the relish is but heightened by a conscientious refusal to disturb the satisfaction's completeness with the rattle of a single contributory penny. So firmly persuaded am I of this gratis-instinct in our common humanity, that I believe I could fill a house by advertising a free lecture on Tupper considered as a philosophic poet, or on my personal recollections of the late James K. Polk. This being so, I have sometimes wondered that the peep-shows which Nature provides with such endless variety for her children, and to which we are admitted on the bare condition of having eyes, should be so generally neglected. To be sure, eyes are not so common as people think, or poets would bo 
plentier, and perhaps also these exhibitions of hers are cheapened in estimation by the fact that in enjoying them we are not getting the better of anybody else. Your true lovers of nature, however, contrive to get even this solace; and Wordsworth looking upon mountains as his own peculiar sweethearts, was jealous of anybody else who ventured upon even the most innocent flirtation with them. As if such fellows, indeed, could pretend to that nicer sense of what-d'ye-call-it which was so remarkable in him! Marry come up ! Nountains, no doubt, may inspire a profounder and more exclusive passion, but on the whole I am not sorry to have been born and bred among more domestic scenes, where I can be hospitable without a pang. I am going to ask you presently to take potluck with me at a board where Winter shall supply whatever there is of cheer.

I think the old fellow has hitherto had scant justice done him in the main. We make him the symbol of old age or death, and think we have settled the matter. As if old age were never kindly as well as frosty; as if it had no reverend graces of its own as good in their way as the noisy impertinence of childhood, the elbowing selfconceit of youth, or the pompous mediocrity of middle life! As if there were anything discreditable in death, or nobody had ever longed for it! Suppose we grant that Winter is the sleep of the year, what then? I take it upon me to say that his dreams are finer than the best reality of his waking rivals.

\section{"Sleep, Silence' child, the father of soft Rest,"}

is a very agreeable acquaintance, and most of us are better employed in his company than anywhere else. For my own part, I think Winter a pretty wide-awake old boy, and his bluff sincerity and hearty ways are more congenial to my mood, and more wholesome for me, 
than any charms of which his rivals are capable. Spring is a fickle mistress, who either does not know her own mind, or is so long in making it up, whether you shall have her or not have her, that one gets tired at last of her pretty miffs and reconciliations. You go to her to be cheered up a bit, and ten to one catch her in the sulks, expecting you to find enough good-humor for both. After she has become Mrs. Summer she grows a little more staid in her demeanor; and her abundant table, where you are sure to get the earliest fruits and vegetables of the season, is a goor foundation for steady friendship; but she has lost that delicious aroma of maidenhood, and what was delicately rounded grace in the girl gives more than hints of something like redundance in the matron. Autumn is the poet of the family. He gets you up a splendor that you would say was made out of real sunset; but it is nothing more than a few hectic leaves, when all is done. He is but a sentimentalist, after all ; a kind of Lamartine whining along the ancestral arenues he has made bare timber of, and begging a contribution of good-spirits from your own savings to keep him in countenance. But Winter has his delicate sensibilities too, only he does not make them as good as indelicate by thrusting them forever in your face. He is a better poet than Autumn, when he has a mind, but, like a truly great one as he is, he brings you down to your bare manhood, and bids you understand him out of that, with no adventitious helps of association, or he will none of you. He does not touch those melancholy chords on which Autumn is as great a master as Heine. Well, is there no such thing as thrumming on them and maundering over them till they get out of tune, and you wish some manly hand would crash through them and leave them dangling brokenly forever? Take Winter as you find him, and ho 
turns out to be a thoroughly honest fellow, with no nonsense in him, and tolerating none in you, which is a great comfort in the long rum. He is not what they call a genial critic ; but bring a real man along with you, and you will find there is a crabbed generosity about the old cynic that you would not exchange for all the creamy concessions of Autumn. "Season of mists and mellow fruitfulness," quotha? That 's just it; Winter soon blows your head clear of fog and makes you see things as they are; I thank him for it! The truth is, between ourselves, I have a very good opinion of the whole family, who always welcome me without making me feel as if I were too much of a poor relation. There ought to be some kind of distance, never so little, you know, to give the true relish. They are as good company, the worst of them, as any I know, and I am not a little flattered by a condescension from any one of them; but I happen to hold Winter's retainer, this time, and, like an honest advocate, am bound to make as good a showing as I can for him, eren if it cost a few slurs upon the rest of the houschold. Noreorer, Winter is coming, and one would like to get on the blind side of him.

The lore of Nature in and for herself, or as a mirror for the moods of the mind, is a modern thing. The fleeing to her as an escape from man was brought into fashion by Rousscau ; for his prototype Petrarch, though he had a taste for pretty scenery, had a true antique horror for the grander aspects of nature. He got once to the top of Mont Ventoux, but it is rery plain that he did not enjoy it. Indeed, it is only within a century or so that the scarch after the picturesque has becn a safe $\mathrm{cm}$ ployment. It is not so eren now in Greece or Southern Italy. Where the Anglo-Saxon carves his cold fowl, and leaves the relies of his pienic, the ancient or medireral man might be pretty coufident that some ruffian would 
try the edge of his knife on a chicken of the Platonic sort, and leave more precious bones as an offering to the genius of the place. The ancients were certainly more social than we, though that, perhaps, was natural enough, when a good part of the world was still covered with forest. They huddled together in cities as well for safety as to keep their minds warm. The Romans had a fondness for country life, but they had fine roads, and Rome was always within easy rench. The author of the Book of Job is the earliest I know of who showed any profound sense of the moral meaning of the outward world; and I think none has approached him since, though Wordsworth comes nearest with the first two books of the "Prelude." But their feeling is not precisely of the kind I speak of as modern, and which gave rise to what is called descriptive poetry. Chaucer opens his Clerk's Tale with a bit of landscape admirable for its large style, and as well composed as any Claude.

"There is right at the west end of Itaille,

Down at the root of Vesulus the cold,

A lusty plain abundant of vitaille,

Where many a tower and town thou mayst behold,

That founded were in time of fathers old,

And many an other délectable sight;

And Salucës this noble country hight."

What an airy precision of touch there is here, and what a sure eje for the points of character in landscape! But the picture is altogether subsidiary. No doubt the works of Salvator Rosa and Gaspar Poussin show that there must have been some amatenr taste for the grand and terrible in scenery; but the British poet Thomson ("sweet-souled" is Wordsworth's apt word) was the first to do with words what they had done partially with colors. He was turgid, no good metrist, and his English is like a translation from one of those poets who wrote in Latin after it was dead; but he was a man of sincere 
genius, and not only English, but European literature is largely in his debt. He was the inventor of cheap amusement for the million, to be had of All-out-doors for the asking. It was his impulse which unconsciously gave direction to Rousseau, and it is to the school of Jean Jacques that we owe St. Pierre, Cowper, Châteaubriand, Wordsworth, Byron, Lamartine, George Sand, Ruskin, the great painters of ideal landscape.

So long as men had slender means, whether of keeping out cold or checkmating it with artificial heat, Winter was an unwelcome guest, especially in the country. There he was the bearer of a lettre de cachet, which shut its rictims in solitary confinement with few resources but to boose round the fire and repeat ghoststories, which had lost all their freshmess and none of their terror. To go to bed was to lie awake of cold, with an added shudder of fright whenever a loose casement or a waring curtain chose to give you the gooseflesh. Bussy Rabutin, in one of his letters, gives us a notion how uncomfortable it was in the country, with green wood, smoky chimneys, and doors and windows that thought it was their duty to make the wind whistle, not to keep it out. With fuel so clear, it could not have been much better in the eity, to judge by Ménage's warning against the danger of our dressing-gowns taking fire, while we cuddle too closely over the sparing blaze. The poet of Winter himself is said to have written in bed, with his hand through a hole in the blanket; and we may suspect that it was the warmth quite as much as the company that first drew men together at the coffee-house. Coleridge, in January, 1800, writes to Wedgewood: "I am sitting by a fire in a rug greatcoat. . . . It is most barbarously cold, and you, I fear, can shield yourseif from it only by perpetual imprisonment." This thermometrical view of winter is, I grant, a 
depressing one ; for I think there is nothing so demoralizing as cold. I know of a boy who, when his father, a bitter economist, was brought home dead, said only, "Now we can burn as much wood as we like." I would not off-hand prophesy the gallows for that boy. I remember with a shudder a pinch I got from the cold once in a railroad-car. A born fanatic of fresh air, I found myself glad to see the windows hermetically sealed by the freezing vapor of our breath, and plotted the assassination of the conductor every time he opened the door. I felt myself sensibly barbarizing, and would have shared Colonel Jack's bed in the ash-hole of the glass-furnace with a grateful heart. Since then I have had more charity for the prevailing ill-opinion of winter. It was natural enough that Ovid should measure the years of his exile in Pontus by the number of winters.

Ut sumus in Ponto, ter frigore constitit Ister, Facta est Euxini dura ter unda maris:

Thrice hath the cold bound Ister fast, since I

In Pontus was, thrice Euxine's wave made hard.

Jubinal has printed an Anglo-Norman piece of dcggerel in which Winter and Summer dispute which is the better man. It is not without a kind of rough and inchoate humor, and I like it because old Whitebeard gets tolerably fair play. The jolly old fellow boasts of his rate of living, with that contempt of poverty which is the weak spot in the burly English nature.

Jà Dieu ne place que me avyenge

Que ne face plus honour

Et plus despenz en un soul jour

Que vus en tote vostre vie:

Now God forbid it hap to me

That I make not more great display,

And spend more in a single day

Than you can do in all your life.

The best touch, perhaps, is Winter's claim for credit as a mender of the highways, which was not without point 
when every road in Europe was a quagmire during a good part of the year unless it was bottomed on some remains of Roman engineering.
Je su, fet-il, seignur et mestre
Et à bon droit le dey estre,
Quant de la bowe face caucé
Par un petit de geelé:
Master and lord I am, says he, And of good right so ought to be, Since I make causeys, safely crost,
Of mud, with just a pinch of frost.

But there is no recognition of Winter as the best of outdoor company.

Even Emerson, an open-air man, and a bringer of it, if ever any, confesses,

"The frost-king ties my fumbling feet,

Sings in my ear, my hands are stones,

Curdles the blood to the marble bones,

Tugs at the heartstrings, numbs the sense,

And hems in life with narrowing fence."

Winter was literally "the inverted year," as Thomson called him; for such entertainments as could be had must be got within doors. What cheerfulness there was in brumal verse was that of Horace's dissolve frigus ligna supor foco large reponens, so pleasantly associated with the clererest scene in Roderick Random. This is the tone of that poem of Walton's friend Cotton, which won the praise of Wordsworth :-

"Let us home,

Our mortal enemy is come;

Winter and all his blustering train

Have made a voyage o'er the main.

"Fly, fly, the foe advances fast;

Into our fortress let us haste,

Where all the roarers of the north

Can neither storm nor starve us forth.

"There underground a magazine

Of sovereign juice is cellared in,

Liquor that will the siege maintain

Should Phœbus ne'er return again. 
"Whilst we together jovial sit

Careless, and crowned with mirth and wit,

Where, though bleak winds confine us home

Our fancies round the world shall roam."

Thomson's view of Winter is also, on the whole, a hostile one, though he does justice to his grandeur.

"Thus Winter falls,

A heavy gloom oppressive o'er the world,

Through Nature shedding influence malign."

He finds his consolations, like Cotton, in the house, though more refined:-

"While without

The ceaseless winds blow ice, be my retreat

Between the groaning forest and the shore

Beat by the boundless multitude of waves,

A rural, sheltered, solitary scene,

Where ruddy fire and beaming tapers join

To cheer the gloom. There studious let me sit

And hold high converse with the mighty dead."

Doctor Akenside, a man to be spoken of with respect, follows Thomson. With him, too, "Winter desolates the year," and

"How pleasing wears the wintry night

Spent with the old illustrious dead!

While by the taper's trembling light

I seem those awful scenes to tread

Where chiefs or legislators lie," \&c.

Akenside had evidently been reading Thomson. He had the conceptions of a great poet with less faculty than many a little one, and is one of those versifiers of whom it is enough to say that we are always willing to break him off in the middle with an \&c., well knowing that what follows is but the coming-round again of what went before, marching in a circle with the cheap numerosity of a stage-army. In truth, it is no wonder that the short days of that cloudy northern climate should have added to winter a gloom borrowed of the mind. We hardly know, till we have experienced the contrast, how sensibly our winter is alleviated by the longer daylight and the 
pellucid atmosphere. I once spent a winter in Dresden, a southern climate compared with England, and really alınost lost my respect for the sun when I saw him groping among the chimney-pots opposite my windows as he described his impoverished are in the sky. The enforced seclusion of the season makes it the time for serious study and occupations that demand fixed incomes of unbroken time. This is why Milton said "that his vein never happily flowed but from the autumnal equinox to the vernal," though in his twentieth year he had written, on the return of spring, -

Fallor? an et nobis redeunt in carmina vires

Ingeniumque mihi munere veris adest?

Err I? or do the powers of song return

To me, and genius too, the gifts of Spring ?

Goethe, so fir as I remember, was the first to notice the checrfulness of snow in sunshine. His IIarz-reise im Winter gives no hint of it, for that is a diluted reminiscence of Greek tragic choruses and the Book of Job in nearly equal parts. In one of the singularly interesting and characteristic letters to Frau von Stein, however, written during the journey, he says : "It is beantiful indeed ; the mist heaps itself together in light snow-clouds, the sun looks through, and the snow over everything gives back a feeling of gayety." But I find in Cowper the first recognition of a general amiability in Winter. The gentleness of his temper, and the wide charity of his sympathies, made it natural for him to find good in everything except the human heart. A dreadful creed distilled from the darkest moments of dyspeptic solitaries compelled him against his will to see in that the one evil thing made by a God whose goodness is over all his works. Cowper's two walks in the morning and noon of a winter's day are delightful, so long as he contrives to let himself be happy in the graciousness of the landscape. 
Your muscles grow springy, and your lungs dilato with the crisp air as you walk along with him. You laugh with him at the grotesque shadow of your legs lengthened across the snow by the just-risen sun. I know nothing that gives a purer feeling of out-door exhilaration than the easy verses of this escaped hypochondriac. But Cowper also preferred his sheltered garden-walk to those robuster joys, and bitterly acknowledged the depressing influence of the darkened year. In December, 1780, he writes: "At this season of the year, and in this gloomy uncomfortable climate, it is no easy matter for the owner of a mind like mine to divert it from sad subjects, and to fix it upon such as may administer to its amusement." Or was it because he was writing to the dreadful Newton? Perhaps his poetry bears truer witness to his habitual feeling, for it is only there that poets disenthral themselves of their reserve and become fully possessed of their greatest charm, - the power of being franker than other men. In the Third Book of the Task he boldly affirms his preference of the country to the city even in winter :-

\footnotetext{
"But are not wholesome airs, though unperfumed By roses, and clear suns, though scarcely felt, And groves, if inharmonious, yet secure From clamor, and whose very silence charms, To be preferred to smoke ? . . . .

They would be, were not madness in the head And folly in the heart; were England now What England was, plain, hospitable kind, And undebauched."
}

The conclusion shows, however, that he was thinking mainly of fireside delights, not of the blusterous companionship of nature. This appears even more clearly in the Fourth Book :-

"O Winter, ruler of the inverted year" ;

but I cannot help interrupting him to say how pleasant it always is to track poets through the gardens of their 
predecessors and find out their likings by a flower snapped off here and there to garnish their own nosegays. Cowper had been reading Thomson, and "the inverted year" pleased his fancy with its suggestion of that starry wheel of the zodiac moving round through its spaces infinite. He could not help loving a handy Latinism (especially with elision beauty added), any more than Gray, any more than Wordsworth, - on the sly. But the member for Olney has the floor:-

"O Winter, ruler of the inverted year,

Thy scattered hair with sleet like ashes filled,

Thy breath congealed upon thy lips, thy cheeks

Fringed with a beard made white with other snows

Than those of age, thy forehead wrapt in clouds,

A leafless branch thy sceptre, and thy throne

A sliding car, indebted to no wheels,

But urged by storms along its slippery way,

I love thee all unlovely as thou seem'st,

And dreaded as thou art ! Thou hold'st the sun

A prisoner in the yet undawning east,

Shortening his journey between morn and noon,

And hurrying him, impatient of his stay,

Down to the rosy west, but kindly still

Compensating his loss with added hours

Of social converse and instructive ease,

And gathering at short notice, in one group,

The family dispersed, and fixing thought,

Not less dispersed by daylight and its cares.

I crown thee king of intimate delights,

Fireside enjoyments, homeborn 3appiness,

And all the comforts that the lowly roof

Of undisturbed Retirement, and the hours

Of long uninterrupted evening know."

I call this a good human bit of writing, imaginative, ton, - not so flushed, not so .... highfuluting (let me dare the odious word!) as the modern style since poets have got hold of a theory that imagination is commonsense turned inside out, and not common-sense sublimed, - but wholesome, masculine, and strong in the simplicity of a mind wholly occupied with its theme. To me Cow. 
per is still the bost of our descriptive poets for every-day wear. And what unobtrusive skill he has! How ho heightens, for cxample, your sense of winter-evening seclusion, by the twanging horn of the postman on the bridge! That horn has rung in my ears ever since I first heard it, during the consulate of the second Adams. Wordsworth strikes a deeper note ; but does it not sometimes come over one (just the least in the world) that one would give anything for a bit of nature pure and simple, without quite so strong a flavor of W. W.? W. W. is, of course, sublime and all that - but! For my part, I will make a clean breast of it, and confess that I can't look at a mountain without fancying the late laureate's gigantic Roman nose thrust between me and it, and thinking of Dean Swift's profine version of Romanos rerum dominos into Roman nose! a rare un! dom your nose! But do I judge verses, then, by the impression made on me by the man who wrote them? Not so fast, my good friend, but, for good or evil, the character and its intellectual product are inextricably interfused.

If I remember aright, Wordsworth himself (except in his magnificent skating-scene in the "Prelude") has not much to say for winter out of doors. I cannot recall any picture by him of a snow-storm. The reason may possibly be that in the Lake Country even the winter storms bring rain rather than snow. He was thankful for the Christmas visits of Crabb Robinson, because they "helped him through the winter." His only hearty praise of winter is when, as Général Février, he defeats the French :-

"Humanity, delighting to behold

A fond reflection of her own decay,

Hath painted Winter like a traveller old,

Propped on a staff, and, through the sullen day,

In hooded mantle, limping o'er the plain

As though his weakness were disturbed by pain: 
Or, if a juster fancy should allow

An undisputed symbol of command, The chosen sceptre is a withered bough Infirmly grasped within a withered hand. These emblems suit the helpless and forlom;

But mighty Winter the device shall scorn."

The Scottish poet Grahame, in his "Sabbath," says manfully :-

"Now is the time

To visit Nature in her grand attire";

and he has one little picture which no other poet has surpassed :

"High-ridged the whirlëd drift has almost reached

The powdered keystone of the churchyard porch:

Mute hangs the hooded bell; the tombs lie buried."

Even in our own climate, where the sum shows his winter face as long and as brightly as in central Italy, the seduction of the chimney-corner is apt to predominate in the mind over the sererer satisfactions of muffled fields and penitential woods. The very title of Whittier's delightful "Snow-Bomnd" shows what he was thinking of, though he does vapor a little about digrging out paths. The rerses of Emerson, perfect as a Greek fragment (despite the archaism of a clissyllibic fire), which he has chosen for his epigraph, tell us, too, how the

"Housemates sit

Around the radiant fireplace, enclosed

In a tumultuous privacy of storm."

They are all in a tale. It is always the tristis Ifiems of Virgil. Catch one of them having a kind word for old Barbe Fleurie, unless he whines through some cranny, like a beggar, to heighten their enjoyment while they toast their slippered toes. I grant there is a keen relish of contrast about the bickering flame as it gives an emphasis beyond Gherarclo della Notte to loved faces, or kindles the wloomy gold of volumes scarce less friendly, especially when a tempest is blundering round the 
house. Wordsworth has a fine touch that brings home to us the comfortable contrast of without and within, during a storm at night, and the passage is highly characteristic of a poet whose inspiration always has an undertone of bourgeois :-

"How touching, when, at midnight, sweep

Snow-muffled winds, and all is dark,

To hear, - and sink again to sleep!"

J. H., one of those choice poets who will not tarnish their bright fancies by publication, always insists on a snow-storm as essential to the true atmosphere of whist. Mrs. Battles, in her famous rule for the game, implies winter, and would doubtless have added tempest, if it could be had for the asking. For a good solid read also, into the small hours, there is nothing like that sense of safety against having your evening laid waste, which Euroclydon brings, as he bellows down the chimney, making your fire gasp, or rustles snow-flakes against the pane with a sound more soothing than silence. Encrson, as he is apt to do, not only hit the nail on the head, but drove it home, in that last phrase of the "tumultuous privacy."

But I would exchange this, and gire something to boot, for the privilege of walking out into the vast blur of a north-northeast snow-storm, and getting a strong draught on the furnace within, by drawing the first furrows through its sandy drifts. I love those

\section{"Noontide twilights which snow makes \\ With tempest of the blinding flakes."}

If the wind veer too much toward the east, you get the heavy snow that gives a true Alpine slope to the boughs of your evergrcens, and traces a skeleton of your elms in white; but you must have plenty of north in your gale if you want those driving nettles of frost that sting the cheeks to a crimson manlier than that of fire. During 
the great storm of two winters ago, the most robustious periwig-pated fellow of late years, I waded and floundered a couple of miles through the whispering night, and brought home that feeling of expansion we have after being in good company. "Great things doeth $\mathrm{He}$ which we cannot comprehend; for he saith to the snow, "Be thou on the earth." "

There is admirable snow scenery in Judd's "Margaret," but some one has confiscated my copy of that admirable book, and, perhaps, Homer's picture of a snowstorm is the best yet in its large simplicity :-

"And as in winter-time, when Jove his cold sharp javelins throws Amongst us mortals, and is moved to white the earth with snows, The winds asleep, he freely pours till highest prominents, Hill-tops, low meadows, and the fiolds that crown with most contents The toils of men, seaports and shores, are hid, and every place,

But floods, that fair snow's tender flakes, as their own brood, embrace."

Chapman, after all, though he makes very free with him, comes nearer Homer than anybody else. There is nothing in the original of that fair snow's tender flakes, but neither Pope nor Cowper could get out of their heads the Psalmist's tender phrase, "He giveth his snow like wool," for which also Homer affords no hint. Pope talks of "dissolving fleeces," and Cowper of a "fleecy mantle." But David is nobly simple, while Pope is simply monsensical, and Cowper pretty. If they must have prettiness, Martial would have supplied them with it in his

Densum tacitarum vellus aquarum,

which is too pretty, though I fear it would have pleased Dr. Domne. Eustathius of Thessalonici calls suow ṽ $\delta \omega \rho$ építóєs, woolly water, which a poor old French poet, Godeau, has amplified into this :-

Lorsque la froidure inhumaine

De leur verd ornement depouille les forêts

Sous une neige épaisse il couvre les guérets,

Et la neige a pour eux la chaleur de la laine. 
In this, as in Pope's version of the passage in Homer, there is, at least, a sort of suggestion of snow-storm in the blinding drift of words. But, on the whole, if one would know what snow is, I should advise him not to hunt up what the poets have said about it, but to look at the sweet miracle itself.

The preludings of Winter are as beautiful as those of Spring. In a gray December day, when, as the farmers say, it is too cold to snow, his numbed fingers will let fall doubtfully a few star-shaped flakes, the snow-drops and anemones that harbinger his more assured reign. Now, and now only, may be seen, heaped on the horizon's eastern edge, those "blue clouds" from forth which Shakespeare says that Mars "doth pluck the masoned turrets." Sometimes also, when the sun is low, you will see a single cloud trailing a flurry of snow along the southern hills in a wavering fringe of purple. And when at last the real snow-storm comes, it leaves the earth with a virginal look on it that no other of the seasons can rival, - compared with which, indeed, they seem soiled and vulgar.

And what is there in nature so beautiful as the next morning after such confusion of the elements? Night has no silence like this of busy day. All the batteries of noise are spiked. We see the morement of life as a deaf man sees it, a mere wiraith of the clamorous existence that inflicts itself on our ears when the ground is bare. The earth is clothed in innocence as a garment. Every wound of the landscape is healed; whatever was stiff has been sweetly rounded as the breasts of Aphrodite; what was unsightly has been covered gently with a soft splendor, as if, Cowley would have said, Nature had cleverly let fall her handkerchief to hide it. If the Virgin (Nôtre Dame de la neige) were to come back, here is an earth that would not bruise her foot nor stain it. 


\section{It is}

\section{"The fanned snow}

That 's bolted by the northern blasts twice o'er," -

Soffiata e stretta dai venti Schiavi,

Winnowed and packed by the Sclavonian winds, -

packed so hard sometimes on hill-slopes that it will bear your weight. What grace is in all the curves, as if every one of them had been swept by that inspired thumb of Phidias's journeyman!

Poets have fancied the footprints of the wind in those light ripples that sometimes scurry across smooth water with a sudden blur. But on this gleaming hush the aerial deluge has left plain marks of its course; and in gullies through which it rushed torrent-like, the eye finds its bed irregularly scooped like that of a brook in hard beach-sand, or, in more sheltered spots, traced with outlines like those left by the slidiner edges of the surf upon the shore. The air, after all, is only an infinitely thimner kind of water, such as I suppose we shall have to drink when the state does her whole duty as a moral reformer. Nor is the wind the only thing whose trail you will notice on this sensitive surface. You will find that you have more neighbors and night visitors than you dreamed of. Here is the dainty footprint of a cat; here a dog has looked in on you like an amateur watchman to see if all is right, slumping clumsily about in the mealy treachery. And look! before you were up in the morning, though you were a punctual courtier at the sun's levee, here has been a squirrel zigzagging to and fro like a hound gathering the scent, and some tiny bird searching for unimaginable food, - perhaps for the tinier creature, whatever it is, that drew this slender continuous trail like those made on the wet beach by light borderers of the sea. The earliest autographs were as frail as these. Poseidon traced his lines, or giant birds made their mark, on preadamite sea-margins; and tho 
thunder-gust left the tear-stains of its sudden passion there; nay, we have the signatures of delicatest fernleaves on the soft ooze of æons that dozed away their dreamless leisure before consciousness came upon the earth with man. Some whim of nature locked them fast in stone for us after-thoughts of creation. Which of us shall leave a footprint as imperishable as that of the ornithorhyncus, or much more so than that of these Bedouins of the snow-desert? Perhaps it was only because the ripple and the rain-drop and the bird were not thinking of themselves, that they had such luck. The chances of immortality depend very much on that. How often have we not seen poor mortals, dupes of a season's notoriety, carving their names on seeming-solid rock of merest beach-sand, whose feeble hold on memory shall be washed away by the next wave of fickle opinion! Well, well, honest Jacques, there are better things to be found in the snow than sermons.

The snow that falls damp comes commonly in larger flakes from windless skies, and is the prettiest of all to watch from under cover. This is the kind Homer had in mind; and Dante, who had never read him, compares the dilatate falde, the flaring flakes, of his fiery rain, to those of snow among the mountains without wind. This sort of snowfall has no fight in it, and does not challenge you to a wrestle like that which drives well from the northward, with all moisture thoroughly winnowed out of it by the frosty wind. Burns, who was more out of doors than most poets, and whose barefoot Muse got the color in her cheeks by vigorous exercise in all weathers, was thinking of this drier deluge, when he speaks of the "whirling drift," and tells how

"Chanticleer

Shook off the powthery snaw."

But the damper and more deliberate falls have a choice 
knack at draping the trees; and about eaves or stonewalls, wherever, indeed, the evaporation is rapid, and it finds a chance to cling, it will build itself out in curves of wonderful beauty. I have seen one of these dumb waves, thus caught in the act of breaking, curl four feet beyond the edge of my roof and hang there for days, as if Nature were too well pleased with her work to let it crumble from its exquisite pause. After such a storm, if you are lucky enough to have even a sluggish ditch for a neighbor, be sure to pay it a visit. You will find its banks corniced with what seems precipitated light, and the dark current down below gleams as if with an inward lustre. Dull of motion as it is, you never saw water that seemed alive before. It has a brightness, like that of the eyes of some smaller animals, which gives assurance of life, but of a life foreign and uninteligible.

A damp snow-storm often turns to rain, and, in our freakish climate, the wind will whisk sometimes into the northwest so suddenly as to plate all the trees with crystal before it has swept the sky clear of its last cobweb of cloud. Ambrose Philips, in a poetical epistle from Copenhagen to the Earl of Dorset, describes this strange confectionery of Nature, - for such, I am half ashamed to say, it always seems to me, recalling the "glorified sugar-candy " of Lamb's first night at the theatre. It has an artificial air, altogether beneath the grand artist of the atmosphere, and besides does too much mischief to the trees for a philodendrist to take unmixed pleasure in it. Perhaps it deserves a poct like Philips, who really loved Nature and yet liked her to be mighty fine, as Pepys would say, with a heightening of powder and rouge :-

"And yet but lately have I scen e'en here

The winter in a lovely dress appear. 
Ere yet the clouds let fall the treasured snow,

Or winds begun through hazy skies to blow,

At evening a keen eastern breeze arose,

And the descending rain unsullied froze.

Soon as the silent shades of night withdrew,

The ruddy noon disclosed at once to view

The face of Nature in a rich disguise,

And brightened every object to my eyes;

For every shrub, and every blade of grass,

And every pointed thorn, seemed wrought in glass;

In pearls and rubies rich the hawthorns show,

And through the ice the crimson berries glow;

The thick-sprung reeds, which watery marshes yield,

Seem polished lances in a hostile field;

The stag in limpid currents with surprise

Sees crystal branches on his forehead rise;

The spreading oak, the beech, the towering pine,

Glazed over in the freezing ether shine;

The frighted birds the rattling branches shun,

Which wave and glitter in the distant sun,

When, if a sudden gust of wind arise,

The brittle forest into atoms flies,

The crackling wood beneath the tempest bends

And in a spangled shower the prospect ends."

It is not uninstructive to see how tolerable Ambrose is, so long as he sticks manfully to what he really saw. The moment he undertakes to improve on Nature ha' sinks into the mere court poet, and we surrender him to the jealousy of Pope without a sigh. His "rattling branches " and "crackling forest" are good, as truth always is after a fashion; but what shall we say of that dreadful stag which, there is little doubt, he valued above all the rest, because it was purcly his own?

The damper snow tempts the amateur architect and sculptor. His Pentelicus has been brought to his very door, and if there are hoys to be had (whose company beats all other recipes for prolonging life) a middle-aged Master of the Works will knock the years off his account and make the family Bible seem a dealer in foolish fables, by a ferw hours given heartily to this business. First comes the Sisyphean toil of rolling the clammy 
balls till they refuse to budge farther. Then, if you would play the statuary, they are piled one upon the other to the proper height; or if your aim be masonry, whether of house or fort, they must be squared and beaten solid with the shovel. The material is capable of very pretty effects, and your young companions meanwhile are unconsciously learning lessons in rsthetics. From the feeling of satisfaction with which one squats on the damp floor of his extemporized dwelling, I have been led to think that the backwoodsman must get a sweeter savor of self-reliance from the house his own hands have built than Bramante or Sansovino could ever give. Perhaps the fort is the best thing, for it calls out more masculine qualities and adds the cheer of battle with that dumb artillery which gives pain enough to test pluck without risk of serious hurt. Already, as I write, it is twenty-odd years ago. The balls fly thick and fast. The uncle defends the waist-high ramparts against a storm of nephews, his breast plastered with decorations like another Radetsky's. How well I recall the indomitable good-humor under fire of him who fell in the front at Ball's Bluff, the silent pertinacity of the gentle scholar who got his last hurt at Fair Oaks, the ardor in the charge of the gallant gentleman who, with the death-round in his side, headed his brigade at Cedar Creek! How it all comes back, and they never come! I cannot again be the Vauban of fortresses in the innocent snow, but I shall never see children moulding their clumsy giants in it without longing to help. It was a pretty fancy of the young Vermont sculptor to make his first essay in this evanescent material. Was it a figure of Yonth, I wonder? Would it not be well if all artists could begin in stuff as perishable, to melt away when the sun of prosperity began to shine, and leave nothing behind but the gain of practised hands? It is pleasant 
to fancy that Shakespeare served his apprenticeship at this trade, and owed to it that most pathetic of despair. ing wishes, -

" 0 , that I were a mockery-king of snow, Standing before the sun of Bolingbroke, To melt myself away in water-drops!"

I have spoken of the exquisite curves of snow sur faces. Not less rare are the tints of which they are capable, - the faint blue of the hollows, for the shadows in snow are always blue, and the tender rose of higher points, as you stand with your back to the setting sun and look upward across the soft rondure of a hillside. I have seen within a mile of home effects of color as lovely as any iridescence of the Silberhorn after sundown. Charles II., who never said a foolish thing, gave the English climate the highest praise when he said that it allowed you more hours out of doors than any other, and I think our winter may fairly make the same boast as compared with the rest of the year. Its still mornings, with the thermometer near zero, put a premium on walking. There is more sentiment in turf, perhaps, and it is more elastic to the foot; its silence, too, is wellnigh as congenial with meditation as that of fallen pine-tassel; but for exhilaration there is nothing like a stiff snowcrust that crealss like a cricket at every step, and communicates its own sparkle to the senses. The air you drink is frappé, all its grosser particles precipitated, and the dregs of your blood with them. A purer current mounts to the brain, courses sparkling through it, and rinses it thoroughly of all dejected stuff. There is nothing left to breed an exhalation of ill-humor or despondency. They say that this rarefied atmosphere has lessened the capacity of our lungs. Be it so. Quartpots are for muddier liquor than nectar. To me, the city in winter is infinitely dreary, - the sharp street. 
corners have such a chill in them, and the suow so soon loses its maidenhood to become a mere drab, _ "doing shameful things," as Stecle says of politicians, "without being ashamed." I pine for the Quaker purity of my country landscape. I am speaking; of course, of those winters that are not niggardly of snow, as ours too often are, giving us a gravelly dust instead. Nothing can be unsightlier than those piebald fields where the coarse brown hide of Earth shows through the holes of her ragged ermine. But even when there is abundance of snow, I find as I grow older that there are not so many good crusts as there used to be. When I first observed this, I rashly set it to the account of that general degeneracy in nature (keeping pace with the same melancholy phenomenon in man) which forces itself upon the attention and into the philosophy of middle life. But happening once to be weighed, it occurred to me that an arch which would bear fifty pounds could hardly be blamed for giving way under more than three times the weight. I have sometimes thought that if theologians would remember this in their arguments, and consider that the man may slump through, with no fault of his own, where the boy would have skimmed the surface in safety, it would be better for all parties. However, when you do get a crust that will bear, and know any brooklet that runs down $a$ hillside, be sure to go and take a look at him, especially if your crust is due, as it commonly is, to a cold snnp following eagerly on a thaw. You will never find him so cheerful. As he shrank away after the last thaw, he built for himself the most exquisite caverns of ice to run through, if not "measureless to man" like those of Alph, the sacred river, yet perhaps more pleasing for their narrowness than those for their grandeur. What a cumning silversmith is Frost! The rarest workmanship of Delhi or Genoa 
copies him but clumsily, as if the fingers of all other artists were thumbs. Fernwork and lacework and filagree in endless variety, and under it all the water tinkles like a distant guitar, or drums like a tambourine, or gurgles like the Tokay of an anchorite's dream. Beyond doubt there is a fairy procession marching along those frail arcades and translucent corridors.

"Their oaten pipes blow wondrous shrill, The hemlock small blow clear."

And hark! is that the ringing of Titania's bridle, or the bells of the wee, wee hawk that sits on Oberon's wrist? This wonder of Frost's handiwork may be had every winter, but he can do better than this, though I have seen it but once in my life. There had been a thaw without wind or rain, making the air fat with gray vapor. Towards sundown came that chill, the arant-courier of a northwesterly gale. Then, though there was no perceptible current in the atmosphere, the fog began to attach itself in frosty roots and filaments to the southern side of every twig and grass-stem. The very posts had poems traced upon them by this dumb minstrel. Wherever the moist seeds found lodgement grew an inch-deep moss fine as cobweb, a slender coral-reef, argentine, delicate, as of some silent sea in the moon, such as Agassiz dredges when he dreams. The frost, too, can wield a delicate graver, and in fancy leaves Piranesi far behind. He covers your window-pane with Alpine etchings, as if in memory of that sanctuary where he finds shelter even in midsummer.

Now look down from your hillside across the valley. The trees are leafless, but this is the season to study their anatomy, and did you ever notice before how much color there is in the twigs of many of them? And the smoke from those chimneys is so blue it seems like a feeder of the sky into which it flows. Winter refines it 
and gives it agreeable associations. In summer it sug* gests cookery or the drudgery of steam-engines, but now your fancy (if it can forget for a moment the dreary usurpation of stoves) traces it down to the fireside and the brightened faces of children. Thoreau is the only poet who has fitly sung it. 'T'he wood-cutter rises before day and

"First in the dusky dawn he sends abroad

His early scout, his emissary, smoke,

The earliest, latest pilgrim from his roof,

To feel the frosty air ; ....

And, while he crouches still beside the hearth,

Nor musters courage to unbar the door,

It has gone down the glen with the light wind

And o'er the plain unfurled its venturous wreath.

Draped the tree-tops, loitered upon the hill,

And warmed the pinions of the early bird;

And now, perchance, high in the crispy air,

Has caught sight of the day o'er the earth's edge,

And greets its master's eye at his low door

As some refulgent cloud in the upper sky."

Here is very bad verse and rery good imagination. He had been reading Wordsworth, or he would not have made tree-tops an iimbus. In the Woretum of Virgil (or, if not his, better than most of his) is a pretty picture of a peasant kindling his winter-morning fire. He rises before dawn,

Sollicitaque manu tenebras explorat inertes

Vestigatque focum læsus quem denique sensit.

Parvulus exusto remanebat stipite fumus,

Et cinis obductæ celabat lumina prunæ.

Admovet his pronam submissa fronte lucernam,

Et producit acu stupas humore carentes,

Fxcitat et crebris languentem flatibus ignem ;

Tandem concepto tenebræ fulgore recedunt,

Oppositaque manu lumen defendit ab aura.

With cautious hand he gropes the sluggish dark, Tracking the hearth which, scorched, he feels erelong.

In burnt-out logs a slender smoke remained,

And raked-up ashes hid the cinders' eyes;

Stooping, to these the lamp outstretched he nears, 


\section{A GOOD WORD FOR WINTER}

And, with a needle loosening the dry wick, With frequent breath excites the languid flame.

Before the gathering glow the shades recede, And his bent hand the new-caught light defends.

Ovid heightens the picture by a single touch :--

Ipse genu poito flammas exsuscitat aura.

Kneeling, his breath calls back to life the flames.

If you walk down now into the woods, you may find a robin or a blue-bird among the red-cedars, or a nuthatch scaling deviously the trunk of some hardwood tree with an eye as keen as that of a French soldier foraging for the pot-au-feu of his mess. Perhaps a blue-jay shrills cah cah in his corvine trebles, or a chickadee

"Shows feats of his gymnastic play,

Head downward, clinging to the spray."

But both him and the snow-bird I love better to see tiny fluffs of feathered life, as they scurry about in a driving mist of snow, than in this screne air.

Coleridge has put into verse one of the most beautiful phenomena of a winter walk :-

"The woodman winding westward up the glen At wintry dawn, where o'er the sheep-track's maze The viewless snow-mist weaves a glistening haze, Sees full before him, gliding without tread, An image with a halo round its head."

But this aureole is not peculiar to winter. I have noticed it often in a summer morning, when the grass was heavy with dew, and even later in the day, when the dewless grass was still fiesh enough to have a gleam of its own.

For my own part I prefer a winter walk that takes in the nightfall and the intense silence that crelong follows it. The evening lamps looks yellower by contrast with the snow, and give the windows that hearty look of which our secretive fires have almost robbed them. The stars seem 
To hang, like twinkling winter lamps, Among the branches of the leafless trees,"

or, if you are on a hill-top (whence it is sweet to watch the home-lights gleam out one by one), they look nearer than in summer, and appear to take a conscious part in the cold. Especially in one of those stand-stills of the air that forebode a change of weather, the sky is dusted with motes of fire of which the summer-watcher never dreamed. Winter, too, is, on the whole, the triumphant season of the moon, a moon devoid of sentiment, if you choose, but witb the refreshment of a purer intellectual light, - the cooler orb of middle life. Who ever saw anything to match that gleam, rather divined than seen, which rums before her over the snow, a breath of light, as she rises on the infinite silence of winter night? High in the heavens, also she seems to bring out some intenser property of cold with her chilly polish. The poets have instinctively noted this. When Goody Blake imprecates a curse of perpetual chill upon Harry Gill, she has

"The cold, cold moon above her head";

and Coleridge speaks of

"The silent icicles,

Quietly gleaming to the quiet moon."

As you walk homeward, - for it is time that we should end our ramble, - you may perchance hear the most impressive sound in nature, uniess it be the fall of a tree in the forest during the hush of summer noon. It is the stifled shriek of the lake yonder as the frost throttles it. Wordsworth has described it (too much, I fear, in the style of Dr. Armstrong) :

"And, interrupting oft that enger game, From under Esthwaite's splitting fields of ice,

The pent-up air, struggling to free itself, Gave out to meadow-grounds and hills a loud Protracted yelling, like the noise of wolves Howling in troops along the Bothnic main." 
Thoreau (unless the Finglish lakes have a different dialect from ours) calls it admirably well a "whoop." But it is a noise like none other, as if Demogorgon were moaning inarticulately from under the earth. Let us get within doors, lest we hear it again, for there is something bodeful and uncanny in it. 


\section{ON A CERTAIN CONDESCENSION IN FOREIGNERS.}

WALKING one day toward the Village, as we used to call it in the good old days when almost every diveller in the town had been born in it, I was enjoying that delicious sense of discnthralment from the actual which the deepening twilight brings with it, giving as it does a sort of obscure novelty to things familiar. The coolness, the hush, broken only by the distant bleat of some belated goat, querulous to be disburthened of her milky load, the fow faint stars, more guossed as yet than seen, the sense that the coming dark would so soon fold me in the secure privacy of its disguise, - all things combined in a result as near absolute peace as can be hoped for by a man who knows that there is a writ out against him in the hands of the printer's devil. For the moment, I was enjoying the blessed privilege of thinking without being called on to stand and deliver what I thought to the small public who are good enough to take any interest therein. I love old ways, and the path I was walking felt kindly to the feet it had known for almost fifty years. How many fleeting impressions it had shared with me! How many times I had lingered to study the shadows of the leaves mezzotinted upon the turf that edged it by the moon, of the bare boughs etched with a touch beyond Rembrandt by the same unconscious artist on the smooth page of snow! If I turned round, thrungh dusky tree-gaps came the first twinkle of even- 
ing lamps in the dear old homestead. On Corey's hill I could see these tiny pharoses of love and home and sweet domestic thoughts flash out one by one across the blackening salt-meadow between. How much has not kerosene added to the cheerfulness of our evening landscape! A pair of night-herons flapped heavily over me toward the hidden river. The war was ended. I might walk townward without that aching dread of bulletins that had darkened the July sunshine and twice made the scarlet leaves of October seem stained with blood. I remembered with a pang, half-proud, half-painful, how, so many years ago, I had walked over the same path and felt round my finger the soft pressure of a little hand that was one day to harden with faithful grip of sabre. On how many paths, leading to how many homes where proud Memory does all she can to fill up the fireside gaps with shining shapes, must not men be walking in just such pensive mood as I? Ah, young heroes, safe in immortal youth as those of Homer, you at least carried your ideal hence untarnished! It is locked for you beyond moth or rust in the treasure-chamber of Death.

Is not a country, I thought, that has had such as they in it, that could give such as they a brave joy in dying for it, worth something, then? And as I felt more and more the soothing magic of evening's cool palm upon my temples, as my fancy came home from its revery, and my senses, with reawakened curiosity, ran to the front windows again from the viewless closet of abstraction, and felt a strange charm in finding the old tree and shabby fence still there under the travesty of falling night, nay, were conscious of an unsuspected newness in familiar stars and the fading outlines of hills my earliest horizon, I was conscious of an immortal soul, and could not but rejoice in the unwaning goodliness of the world into which I had been born without any merit of my own. I thought 


\section{ON A CERTAIN CONDESCENSION IN FOREIGNERS.}

of dear Henry Vaughan's rainbow, "Still young and fine!" I remembered people who had to go over to the Alps to learn what the divine silence of snow was, who must run to Italy before they were conscious of the miracle wrought every day under their very noses by the sunset, who must call upon the Berkshire hills to teach them what a painter autumn was, while close at hand the Fresh Pond meadows made all oricls cheap with hues that showed as if a sunset-cloud had been wrecked among their maples. One might be worse off than even in America, I thought. There are some things so elastic that even the heavy roller of democracy cannot flatten them altogether down. The mind can weave itself warmly in the cocoon of its own thoughts and dwell a hermit anywhere. A country without traditions, without ennobling associations, a scramble of parvenus, with a horrible consciousness of shoddy rumning through politics, manners, art, literature, nay, religion itself? I confess, it did not seem so to me there in that illimitable quiet, that serene self-possession of mature, where Collins might have brooded his "Ode to Evening," or where those verses on Solitude in Dodsley's Collection, that Hawthome liked so much, might have been composed. Traditions? Granting that we had none, all that is worth having in them is the common property of the soul, an estate in gavelkind for all the sons of Adam, - and, moreover, if a man cannot stand on his two fect (the prime quality of whoever has left any tradition behind him), were it not better for him to be honest about it at once, and go down on all fours? And for associations, if one have not the wit to make them for himself out of his native earth, no ready-made ones of other men will avail him much. Lexington is none the worse to me for not being in Greece, nor Gettysburg that its name is not Marathon. "Blessed old fields," I was just exclaiming 
to myself, like one of Mrs. Radcliffe's heroes, "dear acres, innocently secure from history, which these eyes first beheld, may you be also those to which they shall at last slowly darken!" when I was interrupted by a voice which asked me in German whether I was the Herr Professor, Doctor, So-and-so? The "Doctor" was by brevet or vaticination, to make the grade easier to iny pocket.

One feels so intimately assured that he is made up, in part, of shreds and leavings of the past, in part of the interpolations of other people, that an honest man would be slow in saying yes to such a question. But "my name is So-and-so" is a safe answer, and I gave it. While I had been romancing with myself, the streetlamps had been lighted, and it was under one of these detectives that have robbed the Old Road of its privilege of sanctuary after nightfall that I was ambushed by my foe. The inexorable villain had taken my description, it appears, that I might have the less chance to escape him. Dr. Holmes tells us that we change our substance, not every seven years, as was once believed, but with every breath we draw. Why had I not the wit to avail myself of the subterfuge, and, like Peter, to renounce my identity, especially, as in certain moods of mind, I have often more than donbted of it myself? When a $\operatorname{man}$ is, as it were, his own front-door, and is thus knocked at, why may he not assume the right of that sacred wood to make every house a castle, by denying himself to all visitations? I was truly not at home when the question was put to me, but had to recall myself from all out-of-doors, and to piece my self-consciousness hastily together as well as I could before I answered it.

I knew perfectly well what was coming. It is seldom that debtors or good Samaritans waylay people under gas-lamps in order to force money upon them, so far as I 
have secn or heard. I was also aware, from considerable experience, that every foreigner is persuaded that, by doing this country the favor of coming to it, he has laid svery native thereof under an obligation, pecuniary or other, as the case may be, whose discharge he is entitledto on demand duly made in person or by letter. Too much learning (of this kind) had made me mad in the provincial sense of the word. I had begun life with the theory of giving something to every begrgar that came along, though sure of never finding a native-born countryman among them. In a small way, I was resolved to emulate Hatem Tai's tent, with its three hundred and sixty-five entrances, one for every day in the year, - I know not whether he was astronomer enough to add another for leap-years. The beggars were a kind of German-silver aristocracy ; not real plate, to be sure, but better than nothing. Where everybody was overworked, they supplied the comfortable equipoise of absolute leisure, so rsthetically needful. Besides, I was but too conscious of a vagrant fibre in myself, which too often thrilled me in my solitary walks with the temptation to wander on into infinite space, and by a single spasm of resolution to emancipate myself from the drudgery of prosaic scrfdom to respectability and the regular course of things. This prompting has been at times my familiar demon, and I could not but feel a kind of respectful sympathy for men who had dared what I had only sketched out to myself as a splendid possibility. For seven years I helped maintain one heroic man on an imaginary journey to Portland, - as fine an example as I have ever known of hopeless loyalty to an ideal. I assisted another so long in a fruitless attempt to reach Mecklenburg-Schwerin, that at last we grinned in each other's faces when we met, like a couple of augurs. He was possessed by this harmless mania 
as some are by the North Pole, and I shall never forget his look of regretful compassion (as for one who was sacrificing his higher life to the fleshpots of Egypt) when I at last advised him somewhat strenuously to go to the D__ , whither the road was so much travelled that he could not miss it. General Banks, in his noble zeal for the honor of his country, would confer on the Secretary of State the power of imprisoning, in case of war, all these seekers of the unattainabie, thus by a stroke of the pen annihilating the single poetic element in our humdrum life. Alas! not everybody has the genius to be a Bobbin-Boy, or doubtless all these also would have chosen that more prosperous line of life! But moralists, sociologists, political economists, and taxes have slowly convinced me that my beggarly sympathies were a sin against society. Especially was the Buckle doctrine of averages (so flattering to our free-will) persuasive with me ; for as there must be in every year a certain number who would bestow an alms on these abridged editions of the Wandering Jew, the withdrawal of my quota could make no possible difference, since some destined proxy must always step forward to fill my gap. Just so many misdirected letters every year and no more! Would it were as easy to reckon up the number of men on whose backs fate has written the wrong address, so that they arrive by mistake in Congress and other places where they do not belong! May not these wanderers of whom I speak have been sent into the world without any proper address at all? Where is our Dead-Letter Office for such? And if wiser social arrangements should furnish us with something of the sort, fancy (horrible thought!) how many a workingman's friend (a kind of industry in which the labor is light and the wages heavy) would be sent thither because not called for in the office where he at present lies! 
But I am leaving my new acquaintance too long under the lamp-post. The same Gano which had hetrayed me to him revealed to me a well-set young man of about half my own age, as well dressed, so far as I could see, as I was, and with every natural qualification for getting his own livelihood as good, if not better, than my own. He had been reduced to the painful necessity of calling upon me by a series of crosses beginning with the Baden Revolution (for which, I own, he seemed rather young, - but perhaps he referred to a kind of revolution practised every season at Baden-Baden), continued by repeated failures in business, for amounts which must convince me of his entire respectability, and ending with our Civil War. During the latter, he had served with distinction as a soldier, taking a main part in every important battle, with a rapid list of which he favored me, and no doubt would have admitted that, impartial as Jonathan Wild's great ancestor, he had been on both sides, had I baited him with a few hints of conservative opinions on a subject so distressing to a gentleman wishing to profit by one's sympathy and unhappily doubtful as to which way it might lean. For all these reasons, and, as he seemed to imply, for his merit in consenting to be born in Germany, he considered himself my natural creditor to the extent of five dollars, which he would handsomely consent to accept in greenbacks, though he preferred specie. The offer was certainly a generous one, and the claim presented with an assurance that carried conviction. But, unhappily, I had been led to remark a curious natural phenomenon. If I was ever weak enough to give anything to a petitioner of whatever nationality, it always rained decayed compatriots of his for a month after. Post hoc ergo propter hoc may not be always safe logic, but here I seemed to perceive a natural connection of cause and effect. Now, a few days 
before I had been so tickled with a paper (professedly written by a benevolent American clergyman) certifying that the bearer, a hard-working German, had long "sofered with rheumatic paints in his limps," that, after copying the passage into my note-book, I thought it but fair to pay a trifling honorurium to the author. I had pulled the string of the shower-bath! It had been rumning shipwrecked sailors for some time, but forthwith it began to pour Teutons, redolent of luger-bier. I could not help associating the apparition of my new friend with this series of otherwise unaccountable phenomena. I accordingly made up my mind to deny the debt, and modestly did so, pleading a native bias towards impecuniosity to the full as strong as his own. He took a high tone with me at once, such as an honest man would naturally take with a confessed repudiator. He even brought down his proud stomach so fir as to join himself to me for the rest of my townward walk, that he might give me his views of the American people, and thus inclusively of myself.

I know not whether it is because I am pigeon-livered and lack gall, or whether it is from an orermastering sense of drollery, but I am apt to submit to such bastings with a patience which afterwards surprises me, being not without my share of warmth in the blood. Perhaps it is because I so often meet with young persons who know rastly more than I do, and especially with so many foreigners whose knowledge of this country is superior to my own. However it may be, I listened for some time with tolerable composure as my self-appointed lecturer gave me in detail his opinions of my country and its people. America, he informed me, was without arts, science, literature, culture, or any native hope of supplying them. We were a people wholly given to moncy-getting, and who, having got it, knew no other 


\section{ON A CERTAIN CONDESCENSION IN FOREIGNERS.}

use for it than to hold it fast. I am fain to confess that I felt a sensible itching of the biceps, and that my fingers closed with such a grip as he had just informed me was one of the effects of our unhappy climate. But happening just then to be where I could aroid temptation by dodging down a by-street, I hastily left him to finish his diatribe to the lamp-post, which could stand it better than I. That young man will never know how near he came to being assaulted by a respectable gentleman of middle age, at the corner of Church Street. I have never felt quite satisfied that I did all my duty by him in not knocking him down. But perhaps he might have knocked me down, and then?

The capacity of indignation makes an essential part of the outfit of every honest man, but I am inclined to doubt whether he is a wise one who allows himself to act upon its first hints. It should be rather, I suspect, a latent heat in the blood, which makes itself felt in character, a steady reserve for the brain, warming the ovim of thought to life, rather than cooking it by a too hasty enthusiasm in reaching the boiling-point. As my pulse gradually fell back to its normal beat, I reflected that I had been uncomfortably near making a fool of myself, - a handy salve of euphuism for our vanity, though it does not always make a just allowance to Nature for her share in the business. What possible claim had my Tentonic friend to rob me of my composure? I am not, I think, specially thin-skinned as to other people's opinions of myself, having, as I conceive, later and fuller intelligence on that point than anybody else can give me. Life is continually weighing us in very sensitive scales, and telling every one of us preciscly what his real weight is to the last grain of dust. Whoever at fifty does not rate himself quite as low as most of his acquaintance would be likely to put him, 
must be either a fool or a great man, and I humbly disclaim being either. But if I was not smarting in person from any scattering shot of niy late companion's commination, why should I grow hot at any implication of my country therein? Surely her shoulders are broad enough, if yours or mine are not, to bear up under a considerable avalanche of this kind. It is the bit of truth in every slander, the hint of likeness in every caricature, that makes us smart. "Art thou there, old Truepenny?" How did your blade know its way so well to that one loose rivet in our armor? I wondered whether Americans were over-sensitive in this respect, whether they were more touchy than other folks. On the whole, I thought we were not. Plutarch, who at least had studied philosophy, if he had not mastered it, could not stomach something Herodotus had said of Bœotia, and devoted an essay to showing up the delightful old traveller's malice and ill-breeding. French editors leave out of Montaigne's "Travels" some remarks of his about France, for reasons best known to themselves. Pachydermatous Deutschland, covered with trophies from every field of letters, still winces under that question which Père Bouhours put two centuries ago, Si un Allemand peut être bel-esprit? John Bull grew apoplectic with angry amazement at the audacious persiflage of Pückler-Muskau. To be sure, he was a prince, - but that was not all of it, for a chance phrase of gentle Hawthorne sent a spasm throngh all the journals of England. Then this tenderness is not peculiar to us? Console yourself, dear man and brother, whatever you may be sure of, be sure at least of this, that you are dreadfully like other people. Human nature has a much greater genius for sameness than for originality, or the world would be at a sad pass shortly. The surprising thing is that men have such a taste for this 


\section{ON A CERTAIN CONDESCENSION IN FOREIGNERS.}

somewhat musty flavor, that an Englishman, for example, should feel himself defrauded, nay, even outraged, when he comes over here and finds a people speaking what he admits to be something like English, and yet so very different from (or, as he would say, to) those he left at home. Nothing, I am sure, equals my thankfulness when I meet an Englishman who is not like every other, or, I may add, an American of the same odd turn.

Certainly it is no shame to a man that he should be as nice about his country as about his sweetheart, and who ever heard eren the friendliest appreciation of that unexpressive she that did not seem to fall infinitely short? Yet it would hardly be wise to hold every one an enemy who could not see her with our own enchanted eyes. It seems to be the common opinion of foreigners that Americans are too tender upon this point. Perhaps we are; and if so, there must be a reason for it. Have we had fair play? Could the eyes of what is called Good Society (though it is so seldom true either to the adjective or noun) look upon a nation of democrats with any chance of receiving an undistorted image? Were not those, moreover, who found in the old order of things an earthly paradise, paying them quarterly dividends for the wisdom of their ancestors, with the punctuality of the seasons, unconscionsly bribed to misunderstand if not to misrepresent us? Whether at war or at peace, there we were, a standing menace to all earthly paradises of that kind, fatal underminers of the very credit on which the dividends were based, all the more hateful and terrible that our destructive agency was so insidious, working invisible in the elements, as it seemed, actire while they slept, and coming upon them in the darkness like an armed man. Could Laius have the proper feelings of a father towards CEdipus, announced 
as his destined destroyer by infallible oracles, and felt to be such by every conscious fibre of his soul? For more than a century the Dutch were the laughing-stock of polite Europe. They were butter-firkins, swillers of beer and schmaps, and their vrouss from whom Holbein painted the all-but loveliest of Madomas, Rembrandt the graceful girl who sits immortal on his knee in Dresden, and Rubens his abounding goddesses, were the synonymes of clumsy vulgarity. Even so late as Irving the ships of the greatest navigators in the world were represented as sailing equally well stern-foremost. That the aristocratic Venetians should have

"Riveted with gigantic piles

Thorough the centre their new-catchëd miles,"

was heroic. But the far more marvellous achievement of the Dutch in the same kind was ludicrous even to. republican Marvell. Meanwhile, during that very century of scorn, they were the best artists, sailors, merchants, bankers, printers, scholars, jurisconsults, and statesmen in Europe, and the genius of Motley has revealed them to us, earning a right to themselves by the most heroic struggle in human annals. But, alas! they were not merely simple burghers who had fairly made themselves High Mightinesses, and could treat on equal terms with anointed kings, but their commonwealth carried in its bosom the germs of democracy. They even unmuzzled, at least after dark, that dreadful mastiff, the Press, whose scent is, or ought to be, so keen for wolves in sheep's clothing and for certain other animals in lions' skins. They made fun of Sacred Majesty, and, what was worse, managed uncommonly well without it. In an age when periwigs made so large a part of the natural dignity of man, people with such a turn of mind were dangerous. How could they seem other than vulgar and hateful ? 


\section{ON A CERTAIN CONDESCENSION IN FOREIGNERS.}

In the natural course of things we succeeded to this unenviable position of general butt. The Dutch had thriven under it pretty well, and there was hope that we could at least contrive to worry along. And we certainly did in a very redoubtable fashion. Perhaps we deserved some of the sarcasm more than our Dutch predecessors in office. We had nothing to boast of in arts or letters, and were given to bragging overmuch of our merely material prosperity, due quite as much to the virtue of our continent as to our own. There was some truth in Carlyle's sneer, after all. Till we had succeeded in some higher way than this, we had only the success of physical growth. Our greatness, like that of enormous Russia, was greatness on the map, - barbarian mass only; but had we gone down, like that other $A$ tlantis, in some vast cataclysm, we should have covered but a pin's point on the chart of memory, compared with those ideal spaces oceupied by tiny Attica and cramped England. At the same time, our eritics somewhat too easily forgot that material must make ready the foundation for ideal triumphs, that the arts have no chance in poor countries. But it must be allowed that democracy stood for a great deal in our shortcoming. The Edinburgh Review never would have thought of asking, "Who reads a Russian book?" and England was satisfied with iron from Sweden without being impertinently inquisitive after her painters and statuaries. Was it that they expocted too much from the mere miracle of Freedom? Is it not the highest art of a Republic to make men of flesh and blood, and not the marble ideals of such? It may be fairly doubted whether we have produced this higher type of man yet. Perhaps it is the collective, not the indiridnal, humanity that is to have a chance of nobler development among us. We shall see. We have a vast amount of imported ignorance, and, still worse, of native ready-made knowl. 
edge, to digest before even the preliminaries of such a consummation can be arranged. IVe have got to learn that statesmanship is the most complicated of all arts, and to come back to the apprenticeship-system too hastily abandoned. At present, we trust a man with making constitutions on less proof of competence than we should demand before we gave him our shoe to patch. We have nearly reached the limit of the reaction from the old notion, which paid too much regard to birth and station as qualifications for office, and have touched the extreme point in the opposite direction, putting the highest of human functions up at auction to be bid for by any creature capable of going upright on two legs. In some places, we have arrived at a point at which civil society: is no longer possible, and already another reaction has begun, not backwards to the old system, but towards fit; ness either from natural aptitude or special training: But will it always be safe to let evils work their own cure by becoming umendurable? Every one of them leaves its taint in the constitution of the body-politic, each in itself, perhaps, trifling, yet all together powerful for evil.

But whatever we might do or leave undone, we were not genteel, and it was uncomfortable to be continually reminded that, though we should boast that we were the Great West till we were black in the face, it did not bring us an inch nearer to the world's Wrest-End. That sacred enclosure of respectability was tabooed to us. The Holy Alliance did not inscribe us on its visiting-list. The Old World of wigs and orders and liveries would shop with us, but we must ring at the area-bell, and not venture to awaken the more angust clamors of the knocker. Our manners, it must be granted, had none of those graces that stamp the caste of Vere de Vere, in whatever museum of British antiquities they may be hidden. In short, we were vulgar 


\section{ON A CERTAIN CONDESCENSION IN FOREIGNERS.}

This was one of those horribly vague accusations, the victim of which has no defence. An umbrella is of no avail against a Seotch mist. It envelops you, it penetrates at every pore, it wets you through without seeming to wet you at all. Vulgarity is an eighth deadly sin, added to the list in these latter days, and worse than all the others put together, since it perils your salvation in this world, - far the more important of the two in the minds of most men. It profits nothing to draw nice distinctions between essential and conventional, for the convention in this case is the essence, and you may break every command of the decalogue with perfect good-breeding, nay, if you are adroit, without losing caste. We, indeed, had it not to lose, for we had never gained it. "How am I vulgar?" asks the culprit, shudderingly. "Because thou art not like unto Us," answers Lucifer, Son of the Morning, and there is no more to be said. The good of this world may be a fallen angel, but he has us there! We were as clean, — so far as my observation goes, I think we were cleaner, morally and physically, than the English, and therefore, of course, than everybody else. But we did not pronounce the diphthong ou as they did, and we said eether and not eyther, following therein the fashion of our ancestors, who unhappily could bring over no English better than Shakespeare's ; and we did not stammer as they had lcarned to do from the courtiers, who in this way flattered the Hanoverian king, a foreigner among the people he had come to reign over. Worse than all, we might have the noblest ideas and the finest sentiments in the world, but we vented them thrcugh that organ by which men are led rather than leaders, though some physiologists would persuade us that Nature furnishes her captains with a fine handle to their faces that Opportunity may get a good purchase on them for dragging them to the front. 
This state of things was so painful that excellent people were not wanting who gave their whole genius to reproducing here the original Bull, whether by gaiters, the cut of their whiskers, by a factitious brutality in their tone, or by an accent that was forever tripping and falling flat over the tangled roots of our common tongue. Martyrs to a false ideal, it never occurred to them that nothing is more hateful to gods and men than a secondrate Englishman, and for the very reason that this planet never produced a more splendid creature than the firstrate one, witness Shakespeare and the Indian Mutiny. Witness that truly sublime self-abnegation of those prisoners lately among the bandits of Greece, where average men gave an example of quict fortitude for which all the stoicism of antiquity can show no match. If we could contrive to be not too unobtrinsively our simple selves, we should be the most delightful of human beings, and the most original ; whereas, when the plating of Anglicism rubs off, as it always will in points that come to much wear, we are liable to very unpleasing conjectures about the quality of the metal underneath. Perhaps one reason why the average Briton spreads himself here with such an easy air of superiority may be owing to the fact that he meets with so many bad imitations as to conclude himself the only real thing in a wilderness of shams. He fancies himself moving through an endless Bloomsbury, where his mere apparition confers honor as an avatar of the court-end of the universe. Not a Bull of them all but is persuaded he bears Europa upon his back. This is the sort of fellow whose patronage is so divertingly insufferable. Thank Heaven he is not the only specimen of cater-cousinship from the dear old Mother Island that is shown to us! Among genuine things, I know nothing more genuine than the better men whose limbs were made in England. So manly- 
tender, so brave, so true, so warranted to wear, they make us proud to feel that blood is thicker than water.

But it is not merely the Englishman ; every European candidly admits in himself some right of primogeniture in respect to us, and pats this shaggy continent on the back with a lively sense of generous unbending. The German who plays the bass-viol has a well-founded contempt, which he is not always nice in concealing, for a country so few of whose children ever take that noble instrument between their knees. His cousin, the $\mathrm{Ph}$. D. from Göttingen, cannot help despising a people who do not grow loud and red over Aryans and Turanians, and are indifferent about their descent from either. The Frenchman feels an easy mastery in speaking his mother tongue, and attributes it to some native superiority of parts that lifts him high above us barbarians of the West. The Italian prima donna sweeps a courtesy of careless pity to the over-facile pit which unsexes her with the bravo! inmocently meant to show a familiarity with foreign usage. But all without exception make no secret of regarding us as the goose bound to deliver them a golden egg in return for their cackle. Such men as Agassiz, Guyot, and Goldwin Smith come with gifts in their hands; but since it is commonly European failures who bring hither their remarkable gifts and acquirements, this view of the case is sometimes just the least bit in the world provoking. To think what a delicious seclusion of contempt we enjoyed till California and our own ostentatious parvenus, flinging gold away in Europe that might have endowed libraries at home, gare us the ill repute of riches! What a shabby downfall from the Arcadia which the French officers of our Revolutionary War fancied they saw here through Rousseau-tinted spectacles! Something of Arcadia there really was, something of the Old Age; and that divine 
provincialism were cheaply repurchased could we have it back again in exchange for the tawdry upholstery that has taken its place.

For some reason or other, the European has rarely been able to see America except in caricature. Would the first Review of the world have printed the niaiseries of Mr. Maurice Sand as a picture of society in any civilized country? Mr. Sand, to be sure, has inherited nothing of his famous mother's literary outfit, except the pseudonyme. But since the conductors of the Revue could not have published his story because it was clever, they must have thought it valuable for its truth. As true as the last-century Englishman's picture of Jean Crapaud! We do not ask to be sprinkled with rosewater, but may perhaps fairly protest against being drenched with the rinsings of an unclean imagination. The next time the Revue allows such ill-bred persons to throw their slops out of its first-floor windows, let it honestly preface the discharge with a gare de l'eau! that we may run from under in season. And $\mathrm{Mr}$. Duvergier d'Hauranne, who knows how to be entertaining! I know le Français est plutôt indiscret que conficant, and the pen slides too easily when indiscretions will fetch so much a page ; but should we not have been tant-soit-peu more cautious had we been writing about people on the other side of the Channel ? But then it is a fact in the natural history of the American long familiar to Europeans, that he abhors priracy, knows not the meaning of reserve, lives in hotels because of their greater publicity, and is never so pleased as when his domestic affairs (if he may be said to have any) are paraded in the newspapers. Barnum, it is woll known, represents perfectly the average national sentiment in this respect. However it be, we are not treated like other people, or perhaps I should say like people who are ever likely to be met with in society. 


\section{ON A CERTAIN CONDESCENSION IN FOREIGNERS.}

Is it in the climate? Either I have a false notion of European manners, or else the atmosphere affects them strangely when exported hither. Perhaps they suffer from the sea-voyage like some of the more delicate wines. During our Civil War an English gentleman of the highest description was kind enough to call upon me, mainly, as it seemed, to inform me how entirely he sympathized with the Confederates, and how sure he felt that we could never subdue them, - "they were the gentlemen of the country, you know." Another, the first greetings hardly over, asked me hcw I accounted for the universal meagreness of my countrymen. To a thinner man than I, or from a stouter man than he, the question might have been offensive. The Marquis of Hartington * wore a secession badge at a public ball in New York. In a civilized country he might have been roughly handled; but here, where the biensèances are not so well understood, of course nobody minded it. A French traveller told me he had been a good deal in the British colonies, and had been astonished to see how soon the people became Americanized. He added, with delightful bonhomie, and as if he were sure it would charm me, that "they even began to talk through their noses, just like you!" I was naturally ravished with this testimony to the assimilating power of democracy, and could only reply that I hoped they would never adopt our democratic patent-method of seeming to settle one's honest debts, for they would find it paying through the nose in the long-run. I am a man of the New

* One of Mr. Lincoln's neatest strokes of humor was his treatment of this gentleman when al laudable curiosity induced him to be presented to the President of the Broken Bubble. Mr. Lincoln persisted in calling him Mr. Partington. Surely the refinement of gnod-breeding could go no further. Giving the young man his real name (already notorious in the newspapers) would have made his visit an insult Had Henri IV. done this, it would have been famous. 
World, and do not know precisely the present fashion of May-Fair, but I have a kind of feeling that if an American (mututo nomine, de te is always frightfully possible) were to do this kind of thing under a European roof, it would induce some disagreeable reflections as to the ethical results of democracy. I read the other day in print the remark of a British tourist who had eaten large quantities of our salt, such as it is (I grant it has not the European savor), that the Americans were hospitable, no doubt, but that it was partly because they longed for foreign visitors to relieve the tedium of their dead-level existence, and partly from ostentation. What shall we do? Shall we close our doors? Not I, for one, if I should so have forfeited the friendship of L. S., most lovable of men. He somehow seems to find us human, at least, and so did Clough, whose poetry will one of these days, perhaps, be found to have been the best utterance in verse of this generation. And T. $\mathrm{H}$. the mere grasp of whose manly hand carries with it the pledge of frankness and friendship, of an abiding simplicity of nature as affecting as it is rare!

The fine old Tory aversion of former times was not hard to bear. There was something even refreshing in it, as in a northeaster to a hardy temperament. When a British parson, travelling in Newfoundland while the slash of our separation was still raw, after prophesying a glorious future for an island that continued to dry its fish under the ægis of Saint George, glances disdainfully orer his spectacles in parting at th- U. S. A., and forebodes for them a "speedy relapse into barbarism," now that they have madly cut themselves off from the humanizing influences of Britain, I smile with barbarian self-conceit. But this kind of thing became by degrees an umpleasant anachronism. For menumhile the young giant was growing, was beginning indeed to feel tight in 
his clothes, was obliged to let in a gore here and thcre in Texas, in California, in New Mexico, in Alaska, and had the scissors and needle and thread rendomed like a ada when the time came. His surope, - the shadow of Brocken-spectre over against what they were coming thisty image as they had of him, it of it. Even in such misty ims clothes were not of any of it. Even in such that his clothes were by a Bond
was painfully evident the
cut hitherto fashionable, nor conceivable Street tailor, - and this in an if we do not keep up apdepends upon clothes, when, fr we of this universe, nay, pearances, the seening-solid into himself, like a mockery your very God, would slump intoring, after all, but a prevailing king of snow, being nothing, houng giant assumed the mode. From this moment respectable aspect of a phenomenon, a suloject of human possible, but at any rate as legithe silurian what-d'ye-callstudy as the glacial period or the simeral drift-heaps is so abems. If the man of the prot the man of the drift that sorbingly interesting, why not the whose irresistible curis just beginning, of the drit interther we will or no? If rent we are just being sucked I confess I should not be frightI were in their place, I confess I sh, and contrived to be ence. Man has survived so much, arving so much! I comfortable on this planet after surters of government am something of a protestant in mastments and cerealso, and am willing to get rid bare benches, if only faith monies and to come down to in God take the plase of a gene Every mortal man of us confidence in ritual and sham. Delt that is absolutely holds stock in the only put the delot of the Maker of sure of payment, and that is the has made. I have no this Universe to the Unirerse lo a panic.

notion of selling out my stock in anced even to the dignity It was something to have advan 
of a phenomenon, and yet I do not know that the relation of the individual American to the individual European was bettered by it ; and that, after all, must adjust itself comfortably before there can be a right understanding between the two. We had been a desert, we became a museum. People came hither for scientific and not social ends. The very cockney could not complete his education without taking a vacant stare at us in passing. But the sociologists (I think they call themselves so) were the hardest to bear. There was no escape. I have even known a professor of this fearful science to come disguised in petticoats. We were crossexamined as a chemist cross-examines a new substance. Human? yes, all the elements are present, though abnormally combined. Civilized? Hm! that needs a stricter assay. No entomologist could take a more friendly interest in a strange bug. After a few such experiences, I, for one, have felt as if I were merely one of those horrid things preserved in spirits (and very bad spirits, too) in a cabinet. I was not the fellow-being of these explorers: I was a curiosity; I was a specimen. Hath not an American organs, dimensions, senses, affections, passions even as a Europcan hath? If you prick us, do we not bleed? If you tickle us, do we not laugh? I will not keep on with Shylock to his next question but one.

Till after our Civil War it never seemed to enter the head of any foreigner, especially of any Englishman, that an American had what could be called a country, except as a place to eat, sleep, and trade in. Then it scemed to strike them suddenly. "By Jove, you know, fellahs don't fight like that for a shop-till!" No, I rather think not. To Americans America is something more than a promise and an expectation. It has a past and traditions of its own. $\Lambda$ descent from men who sacrificed 


\section{ON A CERTAIN CONDESCENSION IN FOREIGNERS.}

everything and came hither, not to better their fortunes, but to plant their idea in virgin soil, should be a good pedigree. There was nerer colony save this that went forth, not to seek gold, but God. Is it not as well to have sprung from such as these as from some burly beggar who came over with Wilhelmus Conquestor, unless, indeed, a line grow better as it runs farther away from stalwart ancestors? And for history, it is dry enough, no doubt, in the books, but, for all that, is of a kind that tells in the blood. I have admitted that Carlyle's sneer had a show of truth in it. But what does lhe himself, like a true Scot, admire in the Hohenzollerns? First of all, that they were canny, a thrifty, forchanded race. Next, that they made a good fight from generation to generation with the chaos around them. That is precisely the battle which the English race on this continent has been carrying doughtily on for two centurics and a half. Doughtily and silently, for you camnot hear in Europe "that crash, the death-song of the perfect tree," that has been going on here from sturdy father to sturdy son, and making this continent habitahle for the weaker Old World breed that has swarmed to it during the last half-century. If ever men did a good stroke of work on this planet, it was the forefathers of those whom you are wondering whether it would not be prudent to acknowledge as far-off cousins. Alas, man of genius, to whom we owe so much, could you see nothing more than the burning of a foul chimney in that clish of Michael and Satan which flamed up under your very eyes?

Before our war we were to Europe but a huge mob of adventurers and shop-kecpers. Leigh Hunt expressed it well enough when he said that he could never think of America without seeing a gigantic counter stretched all along the seaboard. Feudalism had by degrees mado 
commerce, the great civilizer, contemptible. But a tradesman with sword on thigh and very prompt of stroke was not only redoubtable, he had become respectable also. Few people, I suspect, alluded twice to a needle in Sir John Hawkwood's presence, after that doughty fighter had exchanged it for a more dangerous tool of the same metal. Democracy had been hitherto only a ludicrous effort to reverse the laws of nature by thrusting Cleon into the place of Pericles. But a democracy that could fight for an abstraction, whose members held life and goods cheap compared with that larger life which we call country, was not merely unheard-of, but portentous. It was the nightmare of the old World taking upon itself flesh and blood, turning out to be substance and not dream. Since the Norman crusader clanged down upon the throne of the porphyro-geniti, carefully-draped appearances had never received such a shock, had never been so rudely called on to produce their titles to the empire of the world. Authority has had its periods not unlike those of geology, and at last comes Man claiming kingship in right of his mere manhood. The world of the Saurians might be in some respects more picturesque, but the march of events is inexorable, and it is bygone.

The young giant had certainly got out of long-clothes. He had become the enfant terrible of the human household. It was not and will not be easy for the world (especially for our British cousins) to look upon us as grown up. The youngest of nations, its people must also be young and to be treated accordingly, was the syllogism, - as if libraries did not make all nations equally old in all those respects, at least, where age is an advantage and not a defect. Youth, no doubt, has its good qualities, as people feel who are losing it, but boyishmess is another thing. We had been somewhat boyish as a 


\section{ON A CERTAIN CONDESCENSION IN FOREIGNERS.}

nation, a little loud, a little pushing, a little braggart. But might it not partly have been because we felt that we had certain claims to respect that wore not admitted? The war which established our position as a vigorous mationality has also sobered us. A nation, like a man, camnot look death in the eye for four years, without some strange reflections, without arriving at some clearer conscionsness of the stuff it is made of, without some great moral change. Such a change, or the beginning of it, no observant person can fail to see here. Our thought and our politics, our bearing as a people, are assuming a manlier tone. We have been compelled to see what was weak in democracy as well as what was strong. We have begun obscurely to recognize that things do not go of themselves, and that popular government is not in itself a panacea, is no better than any other form except as the rirtue and wisclom of the people make it so, and that when men undertake to do their own kingship, they enter upon the dangers and responsibilities as well as the privileges of the function. Above all, it looks as if we were on the way to be persuaded that no goverument can be carried on by declamation. It is noticealle also that facility of commumication has made the best English and French thought far more directly operative here than ever before. Withont heing Europeanized, our discussion of important questions in statesinanship, political economy, in æesthetics, is taking a broader scope and a higher tone. It had certainly been provincial, one might almost say local, to a very umpleasint extent. Perhaps our experience in soldiership has taught us to value training more than we have been popularly wont. We may possibly come to the conclusion, one of these days, that self-made men may not be always equally skilful in the manufacture of wisdom, may not be divinely commissioned to fabricate the higher qualities of opinion on all possible topies of human interest. 
So long as we continue to be the most commonsinvoled and the least cultivated people in the world, I suppose we must consent to endure this condescending mamner of foreigners toward us. The more friendly they mean to be the more ludicrously prominent it becomes. They can never appreciate the immense amount of silent work that has been done here, making this continent slowly fit for the abode of man, and which will demonstrate itself, let us hope, in the character of the people. Outsiders can only be expected to judge a nation by the amount it has contributed to the civilization of the world; the amount, that is, that can be seen and handled. A great place in history can only be achiered by competitive examinations, nay, by a long course of them. How much new thought have we contributed to the common stock? Till that question can be triumphantly answered, or needs no answer, we must continue to be simply interesting as an experiment, to be studied as a problem, and not respected as an attained result or an accomplished solution. Perhaps, as I have hinted, their patronizing manner toward us is the fair result of their failing to see here anything more than a poor imitation, a plaster-cast of Europe. And are they not partly right? If the tone of the uncultivated American has too often the arrogance of the barbarian, is not that of the cultivated as often rulgarly apologetic? In the America they meet with is there the simplicity, the manliness, the absence of sham, the sincere human nature, the sensitiveness to duty and implied obligation, that in any way distinguishes us from what our orators call "the effete civilization of the old World"? Is there a politician among us daring enough (except a Dana here and there) to risk his future on the chance of our keeping our word with the exactness of superstitious communities like England? Is it certain that 
we shall be ashamed of a bankruptcy of honor, if we can only keep the letter of our bond? with a frank yes. be able to answer all these question visitors that we are At any rate, we would advise but belong to the family not merely curious creatures, bals, we are not to be alof man, and that, as indiritive examination above ways subjected to the compritedged their competence mentioned, even if we above all, we beg them to reas an examining board. Anot to us, as to them, a mere member that America is not be discussed and analyzed, object of external interest marrow. Let them not supbut in us, part of our very marrelves as exiles from the pose that we conceive of on older date than we, though graces and amenities of all olde things not yet all it very much at home in a state wich we mean to make so, might be or should be, but whome and pleasant for men and which we find both wholesonti) to live in. "The full (though perhaps not for clictar be felt here as keenly as tide of human existence" Cross, and in a larger scnse. Johnson felt it at Charing is singular enough to think I know one person who is spot on the habitable globe. Cambridge the very best spo ade a better, but doubtless "Doubtless God could have he never did." England a great while to get over her ans It will take England as, or even passably to co with the of patronage towathelp confounding the people whe has a them. She camnot hing us as lusty juveniles. Sin wholly country, and that whatever good there is in us nothing exconviction that we truth is that we are worth of Anglicism. English, when the have disinfected ourselves of and lavishes cept so far as we have descending just now, aw them. I She is especially cond we had not outgrown then. sugar-plums on us as if we conversions, especially in sudam no believer in sudden conble opinion of people who den conversions to a favorable op 
have just proved you to be mistaken in judgment and therefore unwise in policy. I never blamed her for not wishing well to democracy, - how should she? - but Alabamas are not wishes. Let her not be too hasty in believing Mr. Reverdy Johnson's pleasant words. 'Though there is no thoughtful man in America who would not consider a war with England the greatest of calamities, yet the feeling towards her here is very far from cordial, whatever our Minister may say in the effusion that comes after ample dining. Mr. Adams, with his famous "My Lord, this means war," perfectly represented his country. Justly or not, we have a feeling that we have been wronged, not merely insulted. The only sure way of bringing about a healthy relation between the two countries is for Englishmen to clear their minds of the notion that we are always to be treated as a kind of inferior and deported Englishman whose nature they perfectly understand, and whose back they accordingly stroke the wrong way of the fur with amazing perseverance. Let them learn to treat us naturally on our merits as human beings, as they would a German or a Frenchman, and not as if we were a kind of counterfeit Briton whose crime appeared in every shade of difference, and before long there would come that right feeling which we naturally call a good understanding. The common blood, and still more the common language, are fatal instruments of misapprehension. Let them give un trying to understand us, still more thinking that they do, and acting in various absurd ways as the necessary consequ,ence, for they will never arrive at that devoutly-to-be-wislsied consummation, till they learn to look at us as we are? and not as they suppose us to be. Dear old long-estran oged mother-in-law, it is a great many years since we parte d. Since 1660 , when you married again, you have been I a step-mother to us. Put on your 
82 ON A CERTAIN CONDESCENSION IN FOREIGNERS. spectacles, dear madam. Yes, we have grown, and changed likewise. You would not let us darken your doors, if you could help it. We know that perfectly well. But pray, when we look to be tralk baby to us don't shake that rattle in our faces, nor talk baby to us any longer.

"Do, child, go to it grandam, child; Give grandam kingdom, and a plum, a cherry, and a fig!" 


\section{A GREAT PUBLIC CHARACTER.*}

$\mathrm{T}^{\mathrm{T}}$ is the misfortune of American biography that it contrary to what might have been predicted, this quality in it predominates in proportion as the country grows larger. Wanting any great and acknowledged centre of national life and thought, our expansion has hitherto been rather aggregation than growth; reputations must be hammered out thin to cover so wide a surface, and the substance of most hardly holds out to the boundaries of a single State. Our very history wants unity, and down to the Revolution the attention is wearied and confused by having to divide itself among thirteen parallel threads, instead of being concentred on a single clew. A sense of remoteness and seclusion comes over us as we read, and we cannot help asking ourselves, "Were not these things done in a corner?" Notoriety may be achiered in a narrow sphere, but fame demands for its evidence a more distant and prolonged reverberation. To the world at large we were but a short column of figures in the corner of a bluebook, New England exporting so much salt-fish, timber, and Medford rum, Virginia so many hogsheads of tobacco, and buying with the proceeds a certain amount of English manufactures. The story of our early colonization had a certain moral interest, to be sure, but was altogether inferior in picturesque fascination to that of

* The Life of Josiah Quincy by his son. 
Mexico or Peru. The lives of our worthies, like that of our nation, are bare of those foregone and far-reaching associations with names, the divining-rods of fancy, which the soldicrs and civilians of the old World get for nothing by the mere accident of birth. Their historians and biographers have succeeded to the good-will, as well as to the long-established stand, of the shop of glory. Time is, after all, the greatest of poets, and the sons of Memory stand a better chance of being the heirs of Fame. The philosophic poet may find a proud solace in saying,

\section{"Avia Pieridum peragro loca nullius ante Trita solo";}

but all the while he has the splendid centuries of Greece and Rome behind him, and can begin his poem with invoking a goddess from whom legend derived the planter of his race. His eyes looked out on a landscape saturated with glorions recollections; he had seen Ciesar, and heard Cicero. But who shall conjure with Sangus or Cato Four Corners, - with Israel Putnam or lieturn Jonathan Meigs? We have been transplanted, and for us the long hierarchical succession of history is broken. The Past has not laid its renerable hands upon us in consecration, conveying to us that mysterious influence whose force is in its continuity. We are to Europe as the Church of England to her of Rome. The latter old lady may be the Scarlet Woman, or the Beast with ten horns, if you will, but hers are all the heirlooms, hers that vast spiritual estate of tradition, nowhere yet every. where, whose revenues are none the less fruitful for being levied on the imagination. We may claim that England's history is also ours, but it is a de jure, and not a defacto property that we have in it, - something that may be proved indeed, yet is a merely intellectual sitisfaction, and does not savor of the realty. Have we not 
seen the mockery crown and sceptre of the exiled Stuarts in St. Peter's? the medal struck so lately as $178 t$ with its legend, Hen IX Mag Brit et Hib Rex, whose contractions but faintly typify the scantmess of the fact?

As the novelist complains that sur society wants that sharp contrast of character and costume which comes of caste, $s$, in the narrative of our historians we miss what may be called background and perspective, as if the events and the actors in them failed of that cumulative interest which only a long historical entail can give. Relatively, the erusade of Sir IVilliam P'epperell was of more consequence than that of St. Louis, and yet forgive us, injured shade of the second American baronet, if we find the narrative of Joinville more interesting than your despatches to Governor Shirley. Relatively, the insurrection of that Daniel whose Irish patronymic Shea was euphonized into Shays, as a set-off for the debasing of French chaise into shay, was more dangerous than that of Charles Edward; but for some reason or other (as vice sometimes has the advantage of virtue) the latter is more enticing to the imagination, and the least authentic relic of it in song or story has a relish denied to the painful industry of Minot. Our events seem to fall short of that colossal proportion which befits the monumental style. Look grare as we will, there is something ludicrous in Counsellor Keane's pig being the pirot of a revolution. We are of yesterday, and it is to no purpose that our political augurs divine from the flight of our eagles that to-morrow shall be ours, and flatter us with an all-hail hereafter. Things do really gain in greatness by being acted on a great and cosmopolitan stage, because there is inspiration in the thronged audience, and the nearer match that puts mon on their mettle. IVebster was more largely endowed by nature than Fox, and Fisher Ames not much below Burke as a talker; but what a 
difference in the intellectual training, in the literary culture and associations, in the whole social outfit, of the men who were their antagonists and companions! It should seem that, if it be collision with other minds and with events that strikes or draws the fire from a man, then the quality of those might have something to do with the quality of the fire, - whether it shall be culinary or electric. We have never known the varied stimulus, the inexorable criticism, the many-sided opportunity of a great metropolis, the inspiring reinforcement of an undivided national consciousness. In everything but trade we have missed the invigoration of foreign rivalry. We may prove that we are this and that and the other, our Fourth-of-July orators have proved it time and again, - the census has proved it; but the Muses are women, and have no great fancy for statistics, though easily sileneed by them. We are great, we are rich, we are all kinds of good things ; but did it never occur to you that somchow we are not interesting, exeept as a phenomenon? It may safely be affirmed that for one cultivated man in this country who studies American, there are fifty who study European history, ancient or modern.

Till within a year or two we have heen as distant and obscure to the cres of Europe as Ecuador to our own. Every day brings us nearer, enables us to see the old World more clearly, and by inevitable comparison to judge ourselves with some closer approach to our real value. This has its advantage so long as our culture is, as for a long time it must be, European; for we shall be little better than apes and parrots till we are forced to measure our muscle with the trained and practised champions of that elder civilization. We have at length established our claim to the noblesse of the sword, the first step still of every nation that would make its entry into the best society of history. To maintain ourselves there, 
we must achicve an equality in the more exclusive circle of culture, and to that end must submit ourselves to the Europen standard of intellectual weights and measuresThat we have made the hitherto biggest glin might excite apprehension (were there a dearth of iron), but can never exact respect. That our pianos and patent reapers have won medals does but confirm us in our mechanic and material measure of merit. Te must contribute something more than mere contrivances for the saving of labor, which we have been only too ready to misapply in the domain of thought and the higher kinds of invention. In those Olympic games where nations contend for truly immortal wreaths, it may well be questioned whether a mowing-machine would stand much chance in the chariot-races, - whether a piano, though made by a cheralier, could compete successfully for the prize of music.

We shall have to be content for a good while yet with our provincialism, and must strive to make the best of it. In it lies the germ of nationality, and that is, after all, the prime condition of all thorough-bred greatness of character. To this choicest fruit of a healthy life, well rooted in native soil, and drawing prosperous juices thence, nationality gires the keenest flavor. Mr. Lincoln was an original nian, and in so far a great man; yet it was the Americanism of his every thought, word, and act which not only made his influence equally at home in East and West, but drew the eyes of the outside world, and was the pedestal that lifted him where he could be seen by them. Lincoln showed that native force may transcend local boundaries, but the growth of such nationality is hindered and hampered by our division into so many half-independent communities, each with its oljects of county ambition, and its public men great to the borders of their district. In this way our standaird of greatnoss is insensibly debased. To receive any na- 
tional appointment, a man must have gone through preeisely the worst training for it ; he must have so far narrowed and belittled himself with State politics as to be acceptable at home. In this way a man may become chairman of the Committee on Foreign Affairs, because he knows how to pack a caucus in Catawampus County, or be sent ambassador to Barataria, because he has drunk bad whiskey with every voter in Wildeat City. Should we ever attain to a conscious nationality, it will have the advantage of lessening the number of our great men, and widening our appreciation to the larger scale of the two or three that are left, - if there should be so many. Meanwhile we offer a premium to the production of great men in a small way, by inviting each State to set up the statues of two of its immortals in the Capitol. What a niggardly percentage! Already we are embarrassed, not to find the two, but to choose among the crowd of candidates. Well, seventy-odd heroes in about as many years is pretty well for a young nation. We do not envy most of them their eternal martyrdom in marble, their pillory of indiscrimination. We fincy even native tourists pausing before the greater part of the effigies, and, after reading the names, asking desperately, "Who was he?" Nay, if they should say, "Who the devil was he?" it were a pardonable invocation, for none so fit as the Prince of Darkness to act as cicerone among such palpable obscurities. We recall the court-yard of the Uffizj at Florence. That also is not free of parish celebrities; but Dante, Galileo, Michael Angelo, Macchiavelli, — shall the inventor of the sewing-machine, eren with the buttonholing improrement, let us sar, match with these, or with far lesser than these? Perhaps he was more practically useful than any one of these, or all of them together, but the soul is sensible of a sad difference somewhere. These also were citizens of a provincial capital; 
so were the greater part of Plutarch's heroes. Did they have a better chance than we moderns, - than we Americans ? At any rate they have the start of us, and we must confess that

" By bed and table they lord it o'er us,

Our elder brothers, but one in blood."

Yes, one in blood ; that is the hardest part of it. Is our provincialism then in some great measure due to our absorption in the practical, as we politely call it, meaning the material, - to our habit of estimating greatness by the square mile and the hundred weight? Even during our war, in the midst of that almost unrivalled stress of soul, were not our speakers and newspapers so enslaved to the vulgar habit as to boast ten times of the thousands of square miles it covered with armed men, for once that they alluded to the motive that gave it all its meaning and its splendor? Perhaps it was as well that they did not exploit that passion of patriotism as an advertisement in the style of Barnum or Perham. "I scale one hundred and eighty pounds, but when I'm mad I weigh two ton," said the Ken tuckian, with a true notion of moral avoirdupois. That ideal kind of weight is wonderfully increased by a national feeling, whereby one man is conscious that thirty millions of men go into the balance with him. The Roman in ancient, and the Englishman in modern times, have been most conscious of this representative solidity, and wherever one of them went there stood Rome or England in his shoes. We have made some advance in the right direction. Our civil war, by the breadth of its proportions and the implacability of its demands, forced us to admit a truer valuation, and gave us, in our own despite, great soldiers and sailors, allowed for such by ali the world. The harder problems it has left behind may in time compel us to have great statesmen, with views 
capable of reaching beyond the next election. The criticism of Europe alone can reseue us from the provincialism of an over or filse estimate of ourselves. Let us be thankful, and not angry, that we must accept it as our touchstone. Our stamp has so often been impressed upon base metal, that we cannot expect it to be taken on trust, but we may be sure that true gold will be equally persuasive the world over. Real manhood and honest achievement are nowhere provincial, but enter the select society of all time on an even footing.

Spanish America might be a good glass for us to look into. Those Catharine-wheel republies, always in revolution while the powder lasts, and sure to burn the fingers of whoever attempts intervention, have also their great men, as placidly ignored by us as our own by jealous Europe. The following passage from the life of Don Simon Bolivar might allay many motus animorum, if rightly pondered. Bolivar, then a youth, was travelling in Italy, and his biographer tells us that "near Castiglione he was present at the grand review made by Napoleon of the columns defiling into the plain large enough to contain sixty thousand men. The throne was situated on an eminence that overlooked the plain, and Napoleon on several occasions looked through a glass at Bolivar and his companions, who were at the base of the hill. The hero Casar could not imagine that he beheld the liberator of the world of Columbus!" And small blame to him, one rould say. We are not, then, it seems, the only foundling of Columbus, as we are so apt to take for granted. The great Crenoese did not, as we supposed, draw that first star-guided furrow across the rague of waters with a single eye to the future greatuess of the United States. And have we not sometimes, like the enthusiastic biographer, fancied the old World staring through all its telescopes at us, and wondered that it did 
not recognize in us what we were fully persuaded we were going to be and do?

Our American life is dreadfully barren of those elements of the social picturesque which give piquancy to anecdote. And without anecdote, what is biography, or even history, which is only biography on a larger scale? Clio, though she take airs on herself, and pretend to be "philosophy teaching by example," is, after all, but a gossip who has borrowed Fame's speaking-trumpet, and should be figured with a tea-cup instead of a scroll in her hand. How much has she not owed of late to the tittle-tattle of her gillflirt sister Thalia? In what gutters has not Macaulay raked for the brilliant bits with which he has put together his admirable mosaic picture of England under the last two Stuarts? Even Mommsen himself, who dislikes Plutarch's method as much as Montaigne loved it, cannot get or give a lively notion of ancient Rome, without running to the comic poets and the anecdote-mongers. He gives us the rery beef-tea of history, nourishing and even palatable enough, excellently portalle for a memory that must carry her own packs, and can afford little luggage; but for our own part, we prefer a full, old-fashioned meal, with its sidedishes of spicy gossip, and its last relish, the Stilton of scandal, so it be not too high. One volume of contemporary memoirs, stuffed though it be with lies, (for lies to be good for anything must have a potential probability, must even be true so far as their moral and social setting is concerned,) will throw more light into the dark backward of time than the gravest Camden or Thuanus. If St. Simon is not accurate, is he any the less essentially true? No history gives us so clear an understanding of the moral condition of average men after the restoration of the Stuarts as the unconscious blabbings of the Puritan tailor's son, with his two con- 
sciences, as it were, - an inward, still sensitive in spots, though mostly toughened to India-rubber, and good rather for rubbing out old scores than retaining them, and an outward, alert, and termagantly effective in Mrs. Pepys. But we can have no St. Simons or Pepyses till we have a Paris or London to delocalize our gossip and give it historic breadth. All our capitals are fractional, merely greater or smaller gatherings of men, centres of business rather than of action or influence. Each contains so many souls, but is not, as the word "capital" implies, the true head of a community and seat of its common soul.

Has not life itself perhaps become a little more prosaic than it once was? As the clearing away of the woods scants the streams, may not our civilization have dried up some feeders that helped to swell the current of individual and personal force? We have sometimes thought that the stricter definition and consequent seclusion from each other of the different callings in modern times, as it narrowed the chance of developing and giving variety to character, lessened also the interest of biography. Formerly arts and arms were not divided by so impassilble a barrier as now. There was hardly such a thing as a pélizn. Cresar gets up from writing his Latin Grammar to conquer Gaul, change the course of history, and make so many things possible, - among the rest our English language and Shakespeare. Horace had been a colonel; and from Eschylus, who fought at Marathon, to Ben Jonson, who trailed a pike in the Low Countries, the list of martial civilians is a long one. A man's education scems more complete who has smelt hostile powder from a less sesthetic distance than Goethe. It raises our confidence in Sir Kenelm Digby as a physicist, that he is able to illustrate some theory of acous. tics in his Treatise of Bodies by instancing the effect of 
his guns in a sea-fight off Scanderoon. One would expect the proportions of character to be enlarged by such variety and contrast of experience. Perhaps it will by and by appear that our own Civil War has done something for us in this way. Colonel Higginson comes down from his pulpit to draw on his jack-boots, and thenceforth rides in our imagination alongside of John Bunyan and Bishop Compton. To have stored moral capital enough to meet the drafts of Death at sight, must be an unmatched tonic. We saw our light-hearted youth come back with the modest gravity of age, as if they had learned to throw out pickets against a surprise of any weak point in their temperament. Perhans that American shiftiness, so often complained of, may not be so bad a thing, if, by bringing men acquainted with every humor of fortune and human nature, it puts them in fuller possession of themselves.

But with whatever drawbacks in special sireumstances, the main interest of biography must always lie in the amount of character or essential manhood which the subject of it reveals to us, and events are of import only as means to that end. It is true that lofty and far-seen exigencies may give greater opportunity to some men, whose energy is more sharply spurred by the shout of a multitude than by the grudging Well done! of conscience. Some theorists hare too hastily assumed that, as the power of public opinion increases, the force of private character, or what we call originality, is absorbed into and diluted by it. But we think Horace was right in putting tyrant and mob on a level as the trainers and tests of a man's solid quality. The amount of resistance of which one is capable to whaterer lies outside the conscience, is of more consequence than all other faculties together; and democracy, perhaps, tries this by pressure in more directions, and with a more 
continuous strain, than any other form of society. In Josiah Quincy we have an example of character trained and shaped, under the nearest approach to a pure democracy the world has ever seen, to a firmmess, unity, and self-centred poise that recall the finer types of antiquity, in whom the public and private man were so wholly of a piece that they were truly everywhere at home, for the same sincerity of nature that dignified the hearth carried also a charm of homeliness into the forum. The phrase "a great public character," once common, seems to be going out of fashion, perhaps because there are fewer examples of the thing. It fits Josiah Quincy exactly. Active in civic and academic duties till beyond the ordinary period of man, at fourscore and ten his pen, voice, and renerable presence were still efficient in public affairs. A score of years after the energies of even vigorous men are declining or spent, his mind and character made themselres felt as in their prime. A true pillar of house and state, he stood unflinchingly upright under whatever burden might be laid upon him. The French Revolutionists aped what was itself but a parody of the elder republic, with their hair à la Brutus and their pedantic moralities à lı Cato Minor, but this man unconsciously was the antique Roman they laboriously went about to be. Others have filled places more conspicuous, few have made the place they filled so conspicuous by an exact and disinterested performance of duty.

In the biography of Mr. Quincy by his son there is something of the provincialism of which we have spoken as inherent in most American works of the kind. His was a Boston life in the strictest sense. But provincialism is relative, and where it has a flaror of its own, as in Scotland, it is often agreeable in proportion to its very intensity. The Massachusetts in which Mr. Quincy's habits of thought were acquired was a very different 
Massachusetts from that in which we of later generations have been bred. Till after he had passed middle life, Boston was more truly a capital than any other city in America, before or since, except possibly Charleston. The acknowledged head of New England, with a population of wellnigh purely English descent, mostly derived from the earlier emigration, with ancestral traditions and inspiring memories of its own, it had made its name familiar in both worlds, and was both historically and politically more important than at any later period. The Revolution had not interrupted, but rather given a freer current to the tendencies of its past. Both by its history and position, the town had what the French call a solidarity, an almost personal consciousness, rare anywhere, rare especially in America, and more than ever since our enormous importation of fellow-citizens to whom America means mercly shop, or meat three times a day. Boston has been called the "American Athens." Estheticaliy, the comparison is ludicrous, but politically it was more reasonable. Its population was homogeneous, and there were leading families; while the form of gorernment by torn-meeting, and the facility of social and civic intercourse, gave great influence to popular personal qualities and opportunity to new men. A wide commerce, while it had insensibly softened the asperities of Puritanism and imported enough foreign refinement to humanize, not enough foreign luxury to corrupt, had not essentially qualified the native tone of the town. Retired sea-captains (true brothers of Chaucer's Shipman), whose exploits had kindled the imagination of Burke, added a not unpleasant saror of salt to society. They belonged to the old school of Gilbert, Hawkins, Frobisher, and Drake, parcel-soldiers all of them, who had commanded armed ships and had tales to tell of gallant fights with privateers or pirates, truest represent- 
atives of those Vikings who, if trade in lumber or peltry was dull, would make themselves Dukes of Dublin or Earls of Orkney. If trade pinches the mind, commerce liberalizes it; and Boston was also advantaged with the neighborhood of the country's oldest College, which maintained the wholesome traditions of culture, - where IIomer and Horace are familiar there is a certain amount of cosmopolitanism, - and would not allow bigotry to become despotism. Manners were more self-respectful, and therefore more respectful of others, and personal sensitiveness was fenced with more of that coremonial with which society armed itself whon it surrendered the ruder protection of the sword. We had not then seen a Governor in his chamber at the State-House with his hat on, a cigar in his mouth, and his fect upon the stove. Domestic service, in spite of the proverb, was not seldom an inheritance, nor was household peace dependent on the whim of a foreign armed neutrality in the kitchen. Servant and master were of one stock; there was decent authority and becoming respect; the tradition of the old World lingered after its superstition had passed away. There was an aristocracy such as is healthful in a well-ordered community, founded on public service, and hereditary so long as the virtue which was its patent was not escheated. The clergy, no longer hedged by the reverence exacted by sacerdotal caste, were more than repaid by the consideration willingly paid to superior culture. What changes, many of them for the better, some of them surely for the worse, and all of them inevitable, did not Josiah Quincy see in that wellnigh secular life which linked the war of independence to the war of nationality! We seemed to see a type of them the other day in a colored man standing with an air of comfortable self-possession while his boots were brushed by a youth of eatholic neutral tint, but whom nature had 
planned for white. The same eyes that had looked on Gage's red-coats, saw Colonel Shaw's negro regiment march out of Boston in the national blue. Seldom has a life, itself actively associated with public affairs, spanned so wide a chasm for the imagination. Oglethorpe's offers a parallel, - the aide-de-camp of Prince Eugene calling on John Adams, American Ambassador to England. Most long lives resemble those threads of gossamer, the nearest approach to nothing unmeaningly prolonged, scarce visible pathway of some worm from his cradle to his grave; but Quincy's was strung with seventy active years, each one a rounded bead of usefulness and service.

Mr. Quincy was a Bostonian of the purest type. Since the settlement of the town, there had been a colonel of the Boston regiment in every generation of his family. He lived to see a grandson brevetted with the same title for gallantry in the field. Only child of one among the most eminent advocates of the Revolution, and who but for his untimely death would have been a leading actor in it, his earliest recollections belonged to the heroic period in the history of his native town. With that history his life was thenceforth intimately united by offices of public trust, as Representative in Congress, State Senator, Mayor, and President of the University, to a period beyond the ordinary span of mortals. Even after he had passed ninety, he would not claim to be emeritus, but came forward to brace his townsmen with a courage and warm them with a fire younger than their own. The legend of Colonel Goffe at Deerfield became a reality to the eyes of this generation. The New England breed is rumning out, we are told! This was in all ways a beautiful and fortunate life, - fortunate in the goods of this world, - fortunate, above all, in the force of character which makes fortune 
secondary and subservient. We are fond in this country of what are called self-made men (as if real success could ever be other); and this is all very well, provided they make something worth having of themselves. Otherwise it is not so well, and the examples of such are at best but stuff for the Aluaschar dreams of a false democracy. The gist of the matter is, not where a man starts from, but where he comes out. We are glad to have the biography of one who, beginning as a gentleman, kept himself such to the end, - who, with no necessity of labor; left behind him an amount of thoroughly done work such as few have accomplished with the mighty help of hunger. Some kind of pace may be got out of the veriest jade by the near prospect of oats; but the thorough-bred has the spur in his blood.

Mr. Edmund Quincy has told the story of his father's life with the skill and good taste that might have been expected from the author of " Wensley." Considering natural partialities, he has shown a discretion of which we are oftener reminded by missing than by meeting it. He has given extracts enough from speeches to show their bearing and quality, - from letters, to recall bygone modes of thought and indicate many-sided friendly relations with good and eminent men; above all, he has lost no opportunity to illustrate that life of the past, near in date, yet alien in manners, whose current glides so imperceptibly from one generation into another that we filil to mark the shiftings of its bed or the change in its nature wrought by the affuents that discharge into it on all sides, -here a stream bred in the hills to sweeten, there the sewerage of some great city to corrupt. We camnot but lament that Mr. Quincy did not earlier begin to keep a diary. "Miss not the discourses of the elders," though put now in the Apocrypha, is a wise precept, but incomplete unless we add, "Nor cease 
from recording whatsocver thing thou hast gathered therefrom," - so ready is Oblivion with her fatal shears. The somewhat greasy heap of a literary rag-and-bonepicker, like Atheneus, is turned to gold by time. Even the Virgilium vidi tantum of Dryden about Milton, and of Pope again about Dryden, is worth having, and gires a pleasant fillip to the fancy. There is much of this quality in Mr. Edmund Quincy's book, enough to make us wish there were more. We get a glimpse of President Washington, in 1795, who reminded Mr. Quincy "of the gentlemen who used to come to Boston in those days to attend the General Court from Hampden or Franklin County, in the western part of the State. A little stiff in his person, not a little formal in his manners, not particularly at ease in the presence of strangers. He had the air of a country-gentleman not accustomed to mix much in society, perfectly polite, but not easy in his address and conversation, and not graceful in his gait and movements." Our figures of Washington have been so long equestrian, that it is pleasant to meet him dismounted for once. In the same way we get a card of invitation to a dinner of sixty covers at John Hancock's, and see the rather light-weighted great man wheeled round the room (for he had adopted Lord Chatham's convenient trick of the gout) to converse with his guests. In another place we are presented, with Mr. Merry, the English Minister, to Jefferson, whom we find in an unofficial costume of studied slovenliness, intended as a snub to haughty Albion. Slippers down at the heel and a dirty shirt become weapons of diplomacy and threaten more serious war. Thus many a door into the past, long irrerocably shut upon us, is set ajar, and we of the younger generation on the landing catch peeps of distinguished men, and bits of their table-talk. We drive in from Mr. Lyman's beautiful seat at Waltham (unique

$$
\text { L. of C. }
$$


at that day in its stately swans and half-shy, half-familiar deer) with John Adams, who tells us that Dr. Priestley looked on the French monarchy as the tenth horn of the Beast in Revelation, - a horn that has set more sober wits dancing than that of Huon of Bordeaux. Those were days, we are inclined to think, of more solid and elegant hospitality than our own, - the elegance of manners, at once more courtly and more frugal, of men who had better uses for wealth than merely to display it. Dinners have more courses now, and, like the Gascon in the old story, who could not see the town for the houses, we miss the real dinner in the multiplicity of its details. We might seek long before we found so good cheer, so good company, or so good talk as our fathers had at Lieutenant-Governor Winthrop's or Senator Cabot's.

We shall not do Mr. Edmund Quiney the wrong of picking out in advance all the plums in his volume, leaving to the reader only the less savory mixture that held them together, - a kind of filling unavoidable in books of this kind, and too apt to be what boys at boarding-school call stick-jou, but of which there is no more than could not be helped here, and that light and palatable. But here and there is a passage where we camnot refrain, for there is a smack of Jack Horner in all of us, and a reviewer were nothing without it. Josiah Quincy was born in 1772. His father, returning from a mission to England, died in sight of the dear New England shore three years later. His young widow was worthy of him, and of the son whose character she was to have so large a share in forming. There is something very tonching and beautiful in this little picture of her which Mr. Quincy drew in his extreme old age.

"My mother imbibed, as was usual with the women of the period, the spirit of the times. Patriotism was not then a profession, but an encrgetic principle beating 
in the heart and active in the life. The death of my father, under circumstances now the subject of history, had orerwhelmed her with grief. She viewed him as a victim in the cause of freedom, and cultivated his memory with reneration, regarding him as a martyr, falling, as did his friend Warren, in the defence of the liberties of his country. These circumstances gave a pathos and rehemence to her grief, which, after the first violence of passion had subsided, sought consolation in earnest and solicitous fulfilment of duty to the representative of his memory and of their mutual affections. Love and reverence for the memory of his father was early impressed on the mind of her son, anc. worn into his heart by her sadness and tears. She cultivated the memory of my father in my heart and affections, even in my earliest childhood, by reading to me passages from the poets, and obliging me to learn by heart and repeat such as were best adapted to her own circumstances and feelings. Among others, the whole leave-taking of Hector and Andromache, in the sixth book of Pope's Homer, was one of her favorite lessons, which she made me learn and froquently repeat. Her imagination, probably, found con* solation in the repetition of lines which brought to mind and seemed to typify her own great berearement.

'And think'st thou not how wretched we shall be, A widow I, a helpless orphan he?'

These lines, and the whole tenor of Andromache's address and circumstances, she identified with her own sufferings, which seemed relieved by the tears my repetition of them drew from her."

Pope's Homer is not Homer, perhaps ; but how many noble natures have felt its elation, how many bruised spirits the solace of its bracing, if monotonous melody ! To us there is something inexpressibly tender in this instinct of the widowed mother to find consolation in the 
idealization of her grief by mingling it with those sor. rows which genius has turned into the perennial delight of mankind. This was a kind of sentiment that was healthy for her boy, refining without unnerving, and associating his father's memory with a noble company unassailable by time. It was through this lady, whose image looks down on us out of the past, so full of sweetness and refinement, that Mr. Quincy became of kin with Mr. Wendell Phillips, so justly eminent as a speaker. There is something nearer than cater-cousinship in a certain impetuous audacity of temper common to them both.

When six years old, Mr. Quincy was sent to Phillips Academy at Andover, where he remained till he entered college. His form-fellow here was a man of thirty, who had been a surgeon in the Continental Army, and whose character and adventures might almost seem borrowed from a romance of Smollett. Under Principal Pearson, the laul, though a near relative of the founder of the school, seems to have endured all that severity of the old a posteriori method of scuching which still smarted in Tusser's memory when he sang,

"From Paul's I went, to Eton sent, To learn straightways the Latin phrase, Where fifty-three stripes given to me At once I had."

The young rictim of the wisdom of Solomon was boarded with the parish minister, in whose kindness he found a lenitive for the scholastic discipline he underwent. This gentleman had been a soldier in the Colonial serrice, and Mr. Quincy afterwards gave as a reason for his mildness, that, "while a sergeant at Castle William, he had seen something of mankind." This, no doubt, would be a better preparative for successful dealing with the young than is generally thought. However, the birch was 
then the only classic tree, and every round in the ladder: of learning was made of its inspiring wood. Dr. Pearson, perhaps, thought he was only doing justice to his pupil's claims of kindred by giving him a larger share of the educational advantages which the neighboring forest afforded. The vividness with which this system is always remembered by those who have been subjected to it would seem to show that it really enlivened the attention, and thereby invigorated the memory, nay, might even raise some question as to what part of the person is chosen by the mother of the Muses for her residence. With an appetite for the classics quickened by "Cheever's Accidence," and such other preliminary whets as were then in rogue, young Quincy entered college, where he spent the usual four years, and was graduated with the highest honors of his class. The amount of Latin and Greek imparted to the students of that day was not very great. They were carried through Horace, Sallust, and the De Oratoribus of Cicero, and read portions of Liry, Xenophon, and Homer. Yet the chief end of classical studies was perhaps as often reached then as now, in giving young men a love for something apart from and above the more rulgar associations of life. Mr. Quincy, at least, retained to the last a fondness for certain Latin authors. While he was President of the College, he told a gentleman, from whom we received the story, that, "if he were imprisoned, and allowed to choose one book for his amusement, that should be Horace."

In 1797 Mr. Quincy was married to Miss Eliza Susan Morton of New York, a union which lasted in unbroken happiness for more than fifty years. His case might be eited among the leading ones in support of the old poet's axiom, that

"He never loved, that loved not at first sight"; 
for he saw, wooed, and won in a week. In later life he tried in a most amusing way to account for this rashness, and to find reasons of settled gravity for the happy inspiration of his heart. He cites the evidence of Judge Sedgwick, of Mr. and Mrs. Oliver Wolcott, of the Rev. Dr. Smith, and others, to the wisclom of his choice. But it does not appear that he consulted them beforehand. If love were not too cunning for that, what would become of the charming idyl, renewed in all its wonder and freshness for every generation? Let us be thankful that in every man's life there is a holiday of romance, an illumination of the senses by the soul, that makes him a poet while it lasts. Mr. Quincy caught the enchantment through his ears, a song of Burns heard from the next room conveying the infection, - a fact still inexplicable to him after lifelong meditation thereon, as he "was not rery impressible by music"! To us there is something very characteristic in this rapid energy of Mr. Quiney, something very delightful in his naire account of the affair. It needs the magic of no Dr. Heidegger to make these dried roses, that drop from between the leares of a rolume shut for seventy years, bloom again in all their sweetness. Mr. Edmund Quiney tells us that his mother was " not handsome"; but those who remember the gracious dignity of her old age will hardly agree with him. She must always have had that highest kind of beauty which grows more beautiful with years, and keeps the eyes young, as if with the partial comnivance of Time.

We do not propose to follow Mr. Quincy closely through his whole public life, which, beginning with his thirty-second, ended with his seventy-third year. He entered Congress as the representative of a party privately the most respectahle, publicly the least sagacious, among all those which under different names have 
divided the country. The Federalists were the only proper tories our politics have ever produced, whose conservatism truly represented an idea, and not a mere selfish interest, - men who honestly distrusted democracy, and stood up for experience, or the tradition which they believed for such, against empiricism. During his Congressional career, the government was little more than an attache of the French legation, and the opposition to which he belonged a helpless revenant from the dead and buried Colonial past. There are some questions whose interest dies the moment they are settled; others, into which a moral element enters that hinders them from being settled, though they may be decided. It is hard to revire any enthusiasm about the Embargo, though it once could inspire the boyish Muse of Bryant, or in the impressment quarrel, though the Trent difficulty for a time rekindled its old animosities. The stars in their courses fought against Mr. Quincy's party, which was not in sympathy with the instincts of the people, groping about for some principle of nationality, and finding a substitute for it in hatred of England. But there are several things which still make his career in Congress interesting to us, because they illustrate the personal character of the man. He prepared himself honestly for his duties, by a thorough study of whatever could make him efficient in them. It was not cnough that he could make a good speech; he wished also to have something to say. In Congress, as everywhere else, quod voluit valde voluit; and he threw a fervor into the most temporary topic, as if his eternal salvation depended upon it. He had not merely, as the French say, the courage of his opinions, but his opinions became principles, and gave him that gallantry of fanaticism which made him always ready to head a forlorn hope, the more ready, perhaps, that it was a forlorn hope 
This is not the humor of a statesman, - no, unless he holds a position like that of Pitt, and can charge a whole people with his own enthusiasm, and then we call it genius. Mr. Quincy had the moral firmuess which enabled him to decline a ducl without any loss of personal prestige. His opposition to the Louisiana purchase illustrates that Roman quality in him to which we have alluded. He would not conclude the purchase till each of the old thirteen States had signified its assent. He was reluctant to endow a Sabine city with the privilege of Roman citizenship. It is worth noting, that while in Congress, and afterwards in the State Senate, many of his phrases became the catchwords of party politics. He always dared to say what others deemed it more prudent only to think, and whatever he said he intensified with the whole ardor of his temperament. It is this which makes Mr. Quincy's speeches good reading still, even when the topies they discussed were ephemeral. In one respect he is distinguished from the politicians, and must rank with the far-seeing statesmen of nis time. He early foresaw and denounced the political dinger with which the Slave Power threatened the Union. His fears, it is true, were aroused for the balance of power between the old States, rather thin by any moral sensitiveness, which would, indeed, have been an anachronism at that time. But the Civil War justified his prescience.

It was as Maryor of his native city that his remarkable qualities as an administrator were first called into requisition and adequately displayed. He organized the eity government, and put it in working order. To him we owe many reforms in police, in the management of the poor, and other kindred matters, - much in the way of cure, still more in that of prevention. The place demanded a man of courage and firmness, and found 
those qualities almost superabundantly in him. His virtues lost him his office, as such virtues are only too apt to do in peaceful times, where they are felt more as a restraint than a protection. His address on laying down the mayoralty is very characteristic. We quote the concluding sentences:-

"And now, gentlemen, standing as I do in this relation for the last time in your presence and that of my fellowcitizens, about to surrender forever a station full of diffculty, of labor and temptation, in which I have been called to very arduous duties, affecting the rights, property, and at times the liberty of others; concerning which the perfect line of rectitude - though desired was not always to be clcarly discerned; in which great interests have been placed within my control, under circumstances in which it would have been easy to advance private ends and sinister projects; - under these cireumstances, I inquire, as I have a right to inquire, for in the recent contest insinuations have been cast against my integrity, - in this long management of your affairs, whatever errors have been committed, and doubtless there have been many, - have you found in me anything selfish, anything personal, anything mercenary? In the simple language of an ancient seer, I say, 'Behold, here I am; witness against me. Whom have I defrauded? Whom have I oppressed? At whose hands have I received any bribe?'

"Six years ago, when I had the honor first to address the City Council, in anticipation of the event which has now occurred, the following expressions were used: 'In administering the police, in executing the laws, in protecting the rights and promoting the prosperity of the city, its first officer will be necessarily beset and assailed by individual interests, by rival projects, by personal influences, by party passions. The more firm and inflexi. 
ble he is in maintaining the rights and in pursuing the interests of the city, the greater is the probability of his becoming obnoxious to the censure of all whom he causes to be prosecuted or punished, of all whose passions he thwarts, of all whose interests he opposes.'

"The day and the event have come. I retire - as in that first address I told my fellow-citizens, 'If, in conformity with the experience of other republics, faithful exertions should be followed by loss of favor and confidence,' I should retire - 'rejoicing, not, indeed, with a public and patriotic, but with a private and individual joy'; for I shall retire with a consciousness weighed against which all human suffiruges are but as the light dust of the balance."

of his mayoralty we have another anecdote quite Roman in color. He was in the habit of riding early in the morning through the rarious strects that he might look into everything with his own eyes. He was once arrested on a malicious charge of violating the city ordinance against fast driving. He might have resisted, but he appeared in court and paid the fine, because it would serve as a good example "that no citizen was above the law."

Hardly had Mr. Quincy given up the government of the city, when he was called to that of the College. It is here that his stately figure is associated most intimately and warmly with the recollections of the greater number who hold his memory dear. Almost everybody looks back regretfully to the days of some Consul Plincus. Nerer were eyes so bright, never had wine so much wit and good-fellowship in it, never were we ourselves so capable of the various great things we have never done. Nor is it merely the sumset of life that casts such a ravishing light on the past, and makes the western windows of those homes of fancy we have left 
forever tremble with a sentiment of such sweet regret. We set great store by what we had, and cannot have again, however indifferent in itself, and what is past is infinitely past. This is especially true of college life, when we first assume the titles without the responsibilities of manhood, and the President of our year is apt to become our Plancus very early. Popular or not while in office, an ex-president is always sure of enthusiastic cheers at every college festival. Mr. Quincy had many qualities calculated to win favor with the young, - that one above all which is sure to do it, indomitable pluck. With him the dignity was in the man, not in the office. He had some of those little oddities, too, which afford amusement without contempt, and which rather tend to. heighten than diminish personal attachment to superiors in station. His punctuality at prayers, and in dropping asleep there, his forgetfulness of names, his singular inability to make even the shortest off-hand speech to the students, - all the more singular in a practised orator, - his occasional absorption of mind, leading him to hand you his sand-box instead of the leave of absence he had just dried with it, - the old-fashioned courtesy of his, "Sir, your servant," as he bowed you out of his study, - all tended to make him popular. He had also a little of what is somewhat contradictorily called dry humor, not without influence in his relations with the students. In taking leave of the graduating class, he was in the habit of paying them whatever honest compliment he could. Who, of a certain year which shall be nameless, will ever forget the gravity with which he assured them that they were "the best-dressed class that had passed through collegre during his administration" ? How sincerely kind he was, how considerate of youthful levity, will always be gratefully remembered by whoever had occasion to experience it. A visitor not long before 
his death found him burning some memoranda of college peccadilloes, lest they should ever rise up in judgment against the men eminent in Church and State who had been guilty of them. One great element of his popularity with the students was his esprit de corps. However strict in discipline, he was always on our side as respected the outside world. Of his efficiency, no higher testimony could be asked than that of his successor, Dr. Walker. Here also many reforms date from his time. He had that happiest combination for a wise vigor in the conduct of affairs, - he was a conservative with an open mind.

One would be apt to think that, in the various offices which Mr. Quincy successively filled, he would have found enough to do. But his indefatigable activity overflowed. Even as a man of letters, he occupies no inconsiderable place. His "History of Harvard College" is a valuable and entertaining treatment of a subject not wanting in natural dryness. His "Municipal History of Boston," his "History of the Boston Athenæum," and his "Life of Colonel Shaw " have permanent interest and value. All these were works demanding no little labor and research, and the thoroughness of their workmanship makes them remarkable as the by-productions of a busy man. Having consented, when more than eighty, to write a memoir of John Quincy Adams, to be published in the "Proceedings" of the Massachusetts Historical Society, he was obliged to excuse himself. On account of his age? Not at all, but because the work had grown to be a volume under his weariless hand. Olne Hast olune Rast, was as true of him as of Goethe. We find the explanation of his accomplishing so much in a rule of life which he gave, when President, to a young man employed as his secretary, and who was a little behindhand with his work: "When you have a 
number of duties to perform, always do the most disagreeable one first." No advice could have been more in character, and it is perhaps better than the great German's, "Do the duty that lies nearest thee."

Perhaps the most beautiful part of Mr. Quincy's life was his old age. What in most men is decay, was in him but beneficent prolongation and adjournment. His interest in affair's unabated, his judgment undimmed, his fire unchilled, his last years were indeed "lovely as a Lapland night." Till within a year or two of its fall, there were no signs of dilapidation in that stately edifice. Singularly felicitous was Mr. Winthrop's application to him of Wordsworth's verses :-

"The monumental pomp of age

Was in that goodly personage."

Everything that Macbeth foreboded the want of, he had in deserved abundance, - the love, the honor, the obedience, the troops of friends. His equanimity was beautiful. He loved life, as men of large vitality always do, but he did not fear to lose life by changing the scene of it. Visiting him in his ninetieth year with a friend, he said to us, among other things: "I have no desire to die, but also no reluctance. Indeed, I have a considerable curiosity about the other world. I have never been to Europe, you know." Even in his extreme senescence there was an April mood somewhere in his nature "that put a spirit of youth in everything:" He seemed to feel that he could draw against an unlimited credit of years. When eighty-two, he said smilingly to a young man just returned from a foreign tour, "WVell, well, I mean to go myself when I am old enough to profit by it." We have seen many old men whose lives were mere waste and desolation, who made longevity disreputable by their untimely persistence in it; but in Mr. Quincy's length of years there was nothing that was not venerable. To 
him it was fulfilment, not deprivation; the days were marked to the last for what they brought, not for what they took away.

The memory of what Mr. Quincy did will be lost in the crowd of newer activities; it is the memory of what he was that is precious to us. Bonum virum fucile crederes, magnumin libenter. If John Winthrop be the highest type of the men who shaped New England, we can find no better one of those whom New England has shaped than Josiah Quincy. It is a figure that we can contemplate with more than satisfaction, - a figure of admirable example in a democracy as that of a model citizen. His courage and high-mindedness were personal to him; let us believe that his integrity, his industry, his love of letters, his devotion to duty, go in some sort to the credit of the society which gave him birth and formed his character. In one respect he is especially interesting to us, as belonging to a class of men of whom he was the last representative, and whose like we shall never see again. Born and bred in an age of greater social distinctions than ours, he was an aristocrat in a sense that is good even in a republic. He had the sense of a certain personal dignity inherent in him, and which could not be alienated by any whim of the popular will. There is no stouter buckler than this for independence of spirit, no surer guaranty of that courtesy which, in its consideration of others, is but paying a debt of self-respect. During his presidency, Mr. Quincy was once riding to Cambridge in a crowded omnibus. A colored woman got in, and could nowhere find a seat. The President instantly gave her his own, and stood the rest of the way, a silent rebuke of the general rudeness. He was a man of quality in the true sense, - of quality not hereditary, but personal. Position might be taken from him, but he remained where he was. In what he 
valued most, his sense of personal worth, the world's opinion could neither help nor hinder. We do not mean that this was conscious in him; if it had been, it would have been a weakness. It was an instinct, and acted with the force and promptitude proper to such. Let us hope that the scramble of democracy will give us something as good; anything of so classic dignity wo shall not look to see again.

Josiah Quincy was no seeker of office; from first to last he and it were drawn together by the mutual attraction of need and fitness, and it clung to him as most men cling to it. The people often make blunders in their choice; they are apt to mistake presence of speechi fur fresence of mind; they love so to help a man rise from the ranks, that they will spoil a good demagngue to make a bad general; a great many faults may be laid at their door, but they are not fairly to be charged with fickleness. They are constant to whoever is constant to his real self, to the best manhood that is in him, and not to the mere selfishness, the antica lupa so cunning to hide herself in the sheep's fleece even from ourselves. It is true, the contemporary world is apt to be the gull of brilliant parts, and the maker of a lucky poem or picture or statue, the wimner of a lucky battle, gets perhaps more than is due to the solid result of his triumph. It is time that fit honor should be paid also to him who shows a genius for public usefulness, for the achievement of character, who shapes his life to a certain classic proportion, and comes off conqueror on those inward fields where something more than mere talent is demanded for victory. The memory of such men should be cherished as the most precious inheritance which one generation can bequeath to the next. However it might be with popular favor, public respect followed Mr. Quincy unwaveringly for seventy years, and it was 
because he had never forfeited his own. In this, it appears to us, lies the lesson of his life, and his claim upon our grateful recollection. It is this which makes him an example, while the carecrs of so many of our prominent men are only useful for warning. As regards history, his greatness was narrowly provincial; but if the measure of deeds be the spirit in which they are done, that fidelity to instant duty, which, according to Herbert, makes an action fine, then his length of years should be very precious to us for its lesson. Talleyrand, whose life may be compared with his for the strange vicissitude which it witnessed, carried with him out of the world the respect of no man, least of all his own; and how many of our own public men have we seen whose old age but accumulated a disregard which they would gladly have exchanged for oblivion! In Quincy the public fidelity was loyal to the private, and the withdrawal of his old age was into a sanctuary, - a diminution of publicity with addition of influence.

"Conclude we, then, felicity consists

Not in exterior fortunes. ...

Sacred felicity doth ne'er extend

Beyond itself. ....

The swelling of an outward fortune can

Create a prosperous, not a happy man." 


\section{CARLYLE**}

A FEELING of comical sadness is likely to come himself to recollecting the names of different authors that have been fimous, and the number of contemporary immortalities whose end he has seen since coming to manhood. - Many a light, hailed by too careless observers as a fixed star, has proved to be only a short-lived lantern at the tail of a newspaper kite. That literary heaven which our youth saw dotted thick, with rival glories, we find now to have been a stage-sky merely, artificially enkindled from behind; and the cynical daylight which is sure to follow all theatrical enthusiasms shows us ragged holes where once were luminaries, shcer vacancy instead of lustre. Our carthly reputations, says a great poet, are the color of grass, and the same sun that makes the green bleaches it out again. But next morning is not the time to criticise the scene-painter's firmament, nor is it quite fair to examine coldly a part of some general illusion in the absence of that sympathetic enthusiasm, that self-surrender of the fancy, which made it what it was. It would not be safe for all neglected authors to comfort themselves in Wordsworth's fashion, inferring genius in an inverse proportion to public favor, and a high and solitary merit from the world's indifference. On the contrary, it would be more just to argue from popularity a certain amount of real value,

* Apropos of his Frederick the Great. 
though it may not be of that permanent quality which insures enduring fame. The contemporary world and Wordsworth were both half right. He undoubtedly owned and worked the richest vein of his period; but he offered to his contemporaries a heap of gold-bearing quartz where the baser mineral made the greater show, and the purchaser must do his own crushing and smelting, with no guaranty but the bare word of the miner. It was not enough that certain bolder adventurers should now and then show a nugget in proof of the success of their venture. The gold of the poet must be refined, moulded, stamped with the image and superscription of his time, but with a beauty of design and finish that are of no time. The work must surpass the material. Wordsworth was wholly void of that shaping imagination which is the highest criterion of a poet.

Immediate popularity and lasting fame, then, would seem to be the result of different qualities, and not of mere difference in degree. It is safe to prophesy a certain durability of recognition for any author who gives evidence of intellectual force, in whatever kind, above the arerage amount. There are names in literary history which are only names; and the works associated with them, like acts of Congress already agreed on in debate, are read by their titles and passed. What is it that insures what may be called living fame, so that a book shall be at once famous and read? What is it that relegrates divine Cowley to that remote, uncivil Pontus of the "British Pocts," and keeps garrulous Pepys within the checry circle of the evening lamp and fire? Originality, eloquence, sense, imagination, not one of them is enough by itself, but only in some happy mixture and proportion. Imagination seems to possess in itself more of the antiseptic property than any other single quality; but, without less showy and more sub. 
stantial allies, it can at best give only deathlessness, without the perpetual youth that makes it other than dreary. It were easy to find examples of this Tithonus immortality, setting its victims apart from both gods and men; helpless duration, undying; to be sure, but sapless and voiceless also, and long ago deserted by the fickle Hemera. And yet chance could confer that gift on Glaucus, which love and the consent of Zeus failed to secure for the darling of the Dawn. Is it mere luck, then? Luck may, and often does, have some share in ephemeral successes, as in a gambler's winnings spent as soon as got, but not in any lasting triumph over time. Solid success must be based on solid qualities and the honest culture of them.

The first element of contemporary popularity is undoubtedly the power of entertaining. If a man have anything to tell, the world camot be expected to listen to him unless he have perfected himself in the best way of telling it. People are not to be argued into a pleasurable sensation, nor is taste to be compelled by any syllogism, however stringent. An author may make himself very popular, however, and even justly so, by appealing to the passion of the moment, without having anything in him that shall outlast the public whim which he satisfies. Churchill is a remarkable example of this. He had a surprising extemporary vigor of mind; his phrase carries great weight of blow; he undoubtedly surpassed all contemporaries, as Cowper says of him, in a certain rude and earth-born vigor; but his verse is dust and ashes now, solemnly inurned, of course, in the Chalmers columbarium, and without danger of violation. His brawn and muscle are fading traditions, while the fragile, shivering genius of Cowper is still a good life on the books of the Critical Insurance Office. "Is it not, then, loftiness of mind that puts one by the 
side of Virgil?" cries poor old Cavalcanti at his wits' end. Certainly not altogether that. There must be also the great Mantuan's art; his power, not only of being strong in parts, but of making those parts coherent in an harmonious whole, and tributary to it. Gray, if we may believe the commentators, has not an idea, scarcely an epithet, that he can call his own; and yet he is, in the best sense, one of the classies of English literature. He had exquisite felicity of choice; his dictionary had no vulgar word in it, no harsh one, but all culled from the luckiest moods of poets, and with a faint but delicions aroma of association; he had a perfect sense of sound, and one idea without which all the poetic outfit (si clsit prudentiu) is of little avail, - that of combination and arrangement, in short, of art. The poets from whom he helpel himself have no more claim to any of his poems as wholes, than the various beauties of Greece (if the old story were true) to the Venus of the artist.

Imagination, as we have said, has more virtue to keep a book alive than any other single faculty. Burke is rescued from the usual doom of orators, because his learning, his experience, his sagacity are rimmed with a halo by this bewitching light behind the intellectual eye from the highest heaven of the brain. Shakespeare has impregniated his common sense with the stearly glow of it, and answers the mood of youth and age, of high and low, immortal as that dateless sulstance of the soul he wronght in. To have any chance of lasting, a book must sit.isfy, not inerely some flecting fincy of the day, but a constant longing and hunger of human nature; and it necels only a superficial study of literature to be convincer that real fame depends rather on the sum of an author's powers than on any brilliancy of special parts. There must be wisdom as well as wit, sense ne 
less than imngination, judgment in equal measure with fancy, and the fiery rocket must be bound fast to the poor wooden stick that gives it guidance if it would mount and draw all eyes. There are some who think that the brooding patience which a great work calls for belonged exclusively to an earlier period than ours. Others lay the blame on our fashion of periodical publication, which necessitates a sensation and a crisis in every number, and forces the writer to strive for startling effects, instead of that general lowness of tone which is the last achievement of the artist. The simplicity of antique passion, the homeliness of antique pathos, seem not merely to be gone out of fashion, but out of being as well. Modern poets appear rather to tease their words into a fury, than to infuse them with the deliberate heats of their matured coneeption, and strive to replace the rapture of the mind with a fervid intensity of phrase. Our reaction from the decorous platitudes of the last century has no doubt led us to excuse this, and to be thankful for something like real fire, though of stubble; but our prevailing style of criticism, which regards parts rather than wholes, which dwells on the beauty of passages, and, above all, must have its languid nerres pricked with the expected sensation at whatever cost, has done all it could to confirm us in our evil way. Passages are good when they lead to something, when they are necessary parts of the building, but they are not good to dwell in. This taste for the startling reminds us of something which happened once at the burning of a country meeting-house. The building stood on a hill, and, apart from any other considerations, the fire was as picturesque as could be desired. When all was a black heap, licking itself here and there with tongues of fire, there rushed up a farmer gasping anxiously, "Hez the bell fell yit?" An ordinary fire 
was no more to him than that on his hearthstone; even the burning of a meeting-house, in itself a vulcanic rarity, (so long as he was of another parish,) could not tickle his outworn palate; but he had hoped for a certain tang in the downcome of the bell that might recall the boyish flavor of conflagration. There was something dramatic, no doubt, in this surprise of the brazen sentinel at his post, but the breathless rustic has always seemed to us a type of the prevailing delusion in resthetics. Alas! if the bell must fall in every stanza or every monthly number, how shall an author contrive to stir us at last, unless with whole Moscows, crowned with the tintimnabulary crash of the Kremlin? For ourselves, we are glad to feel that we are still able to find contentment in the more conversational and domestic tone of our old-fashioned wood-fire. No doubt a great part of our pleasure in reading is unexpectedness, whether in turn of thought or of phrase; but an emphasis out of place, an intensity of expression not founded on sincerity of moral or intellectual conviction, reminds one of the underscorings in young ladies' letters, a wonder even to themselves under the colder north-light of matronage. It is the part of the critic, however, to keep cool under whatever circumstances, and to reckon that the execsses of an author wiil be at first more attractive to the many than that average power which shall win him attention with a new generation of men. It is scldom found out by the majority, till after a considerable interval, that he was the original man who contrived to be simply natural, - the hardest lesson in the school of art and the latest learned, if, indeed, it be a thing capable of acquisition at all. The most winsome and wayward of brooks draws now and then some lover's foot to its intimate reserve, while the spirt of a bursting water-pipe gathers a gaping crowd forthwith. 
Mr. Carlyle is an author who has now been so long before the world, that we may feel toward him something of the unprejudice of posterity. It has long been evident that he had no more ideas to bestow upon us, and that no new turn of his kaleidoscope would give us anything but some variation of arrangement in the brilliant colors of his style. It is perhaps possible, then, to arrive at some not wholly inadequate estimate of his place as a writer, and especially of the ralue of the ideas whose advocate he makes himself, with a bitterness and violence that increase, as it seems to us, in proportion as his inward conviction of their truth diminishes.

The leading characteristics of an author who is in any sense original, that is to say, who does not merely reproduce, but modifies the influence of tradition, culture, and contemporary thought upon himself by some admixture of his own, may commonly be traced more or less clearly in his earliest works. This is more strictly true, no doubt, of poets, because the imagination is a fixed quantity, not to be increased by any amount of study and reflection. Skill, wisclom, and even wit are cumulative; but that diviner faculty, which is the spiritual eye, though it may be trained and sharpened, cannot be added to by taking thought. This has always been something innate, unaccountable, to be laid to a happy conjunction of the stars. Goethe, the last of the great poets, accordingly takes pains to tell us under what pianets he was born; and in him it is curious how uniform the imaginative quality is from the beginning to the end of his long literary activity. His early poems show maturity, his mature ones a youthful freshness. The apple already lies potentially in the blossom, as that may be traced also in the ripened fruit. With a mere change of emphasis, Goethe might be called an old boy at both ends of his career. 
In the earliest authorship of Mr. Carlyle we find some not obscure hints of the future man. Nearly fifty years ago he contributed a few literary and critical articles to the Edinburgh Encyclopredia. The outward fashion of them is that of the period; but they are distinguished by a certain security of judgment remarkable at any time, remarkable especially in one so young. British criticism has been always more or less parochial; has never, indeed, quite freed itself from sectarian cant, and planted itself honestly on the resthetic point of view. It cannot quite persuade itself that truth is of immortal essence, totally independent of all assistance from quarterly journals or the British army and navy. Carlyle, in these first essays, already shows the influence of his master, Goethe, the most widely receptive of critics. In a compact notice of Montaigne, there is not a word as to his religious scepticism. The character is looked at purely from its human and literary sides. As illustrating the bent of the author's mind, the following passage is most to our purpose: "A modern reader will not easily cavil at the patient and good-natured, though exuberant egotism which brings back to our riew 'the form and pressure' of a time long past. The habits and humors, the mode of acting and thinking, which characterized a Gascon gentleman in the sixteenth century, cannot fail to amuse an inquirer of the nineteenth; while the faithful delineation of human feelings, in all their strength and weakness, will serve as a mirror to every mind capable of self-examination." We find here no uncertain indication of that eye for the moral picturesque, and that sympathetic appreciation of character, which within the next few years were to make Carlyle the first in insight of English critics and the most vivid of English historians. In all his earlier writing he never loses sight of his master's great rule, Den Gegenstand fest zu halten 
He accordingly gave to Englishmen the first humanly possible likeness of Voltaire, Diderot, Nirabcau, and others, who had hitherto been measured by the usual British standard of their respect for the geognosy of Moses and the historic credibility of the Bools of Chronicles. What was the real meaning of this phenomenon? what the amount of this man's honest performance in the world? and in what does he show that family-likeness, common to all the sons of Adam, which gives us a fair hope of being able to comprehend him? These were the questions which Carlyle seems to have set himself honestly to answer in the critical writings which fill the first period of his life as a man of letters. In this mood he rescued poor Boswell from the unmerited obloquy of an ungrateful generation, and taught us to see something half-comically beautiful in the poor, weak creature, with his pathetic instinct of reverence for what was nobler, wiser, and stronger than himself. Everything that Mr. Carlyle wrote during this first period thrills with the purest appreciation of whatever is brave and beautiful in human nature, with the most rehement scorn of cowardly compromise with things base ; and yet, immitigable as his demand for the highest in us seems to be, there is always something reassuring in the humorous sympathy with mortal frailty which softens condemnation and consoles for shortcoming. The remarkable feature of Mr. Carlyle's criticism (see, for example, his analysis and exposition of Goethe's "Helena") is the sleuth-hound instinct with which he presses on to the matter of his theme, - never turned aside by a false scent, regardless of the outward beauty of form, sometimes almost contemptuous of it, in his hunger after the intellectual nourishment which it may hide. The delicate skeleton of admiribly articulated and related parts which underlies and sustains every true work of art, and 
keeps it from sinking on itself a shapeless heap, he would crush remorselessly to come at the marrow of meaning. With him the ideal sense is secondary to the ethical and metaphysical, and he has but a faint conception of their possible unity.

By degrees the humorous element in his nature gains ground, till it overmasters all the rest. Becoming always more boisterous and obtrusive, it ends at last, as such humor must, in cynicism. In "Sirtor Resartus" it is still kindly, still infused with sentiment; and the book, with its mixture of indignation and farce, strikes one as might the prophecies of Jeremiah, if the marginal comments of the Rev. Mr. Sterne in his wildest mood had by some accident been incorporated with the text. In "Sartor" the marked influence of Jean Paul is undeniable, both in matter and mammer. It is curious for one who studies the action and reaction of national literatures on ench other, to see the humor of Swift and Sterne and Ficlding, after filtering through Richter, reappear in Carlyle with a tinge of Germanism that makes it novel, alien, or even displeasing, as the case may be, to the English mind. Unhappily the bit of mother from Swift's vinegar-harrel has had strength enough to sour all the rest. 'The whimsicality of "Tristram Shandy," which, even in the original, has too often the effect of forethought, becomes a deliberate artifice in Richter, and at last a mere mannerism in Carlyle.

Mr. Carlyle in his critical essizys had the advantage of a well-defined theme, and of limits both in the subject and in the space allowed for its treatınent, which kept his natural extravagance within bounds, and compelled some sort of discretion and compactness. The great merit of these essays lay in a criticism based on wide and various study, which, carcless of tradition, npplied its standard to the real and not the contem. 
porary worth of the literary or other performance to be judged, and in an unerring eye for that fleeting expression of the moral features of character, a perception of which alone makes the drawing of a coherent likeness possible. Their defect was a tendency, gaining strength with years, to confound the moral with the asthetic standard, and to make the value of an anthor's work dependent on the general force of his nature rather than on its special fitness for a giren task. In proportion as his humor gradually overbalaneed the other qualities of his mind, his taste for the eccentric, amorphous, and violent in men became excessive, disturbing more and more his perception of the more commonplace attributes which give consistency to portraiture. His "French Revolution" is a series of lurid pictures, unmatched for vehement power, in which the figures of such sons of earth as Nirabeau and Danton loom gigantic and terrible as in the glare of an eruption, their shadows swaying far and wide grotesquely awful. But all is painted by eruption-flashes in violent light and shade. There are no half-tints, no gradations, and we find it impossible to account for the continuance in power of less Titanic actors in the tragedy like Robespierre, on any theory whether of human nature or of individual character supplied by $\mathrm{Mr}$. Carlyle. Of his success, however, in accomplishing what he aimed at, which was to haunt the mind with memories of a horrible political nightmare, there can be no doubt.

Goethe says, apparently thinking of Richter, "The worthy Germans have persuaded themselves that the essence of true humor is formlessness." Heine had not yet shown that a German might combine the most airy humor with a sense of form as delicate as Goethe's orn, and that there was no need to borrow the bow of Philoctetes for all kinds of game. Mr. Carlyle's orwn 
tendency was toward the lawless, and the attraction of Jean Paul made it an overmastering one. Goethe, we think, might have gone farther, and affirmed that nothing but the highest artistic sense can prevent humor from degenerating into the grotesque, and thence downwards to utter anarchy. Rabelais is a striking example of it. The moral purpose of his book cannot give it that unity which the instinct and forethought of art only can bring forth. Perhaps we owe the masterpiece of humorous literature to the fact that Cervantes had been trained to authorship in a school where form predominated over substance, and the most convincing proof of the supremacy of art at the highest period of Greek literature is to be found in Aristophanes. Mr. Carlyle has no artistic sense of form or rhythm, scarcely of proportion. Accordingly he looks on rerse with contempt as something barbarous, - a savage ornament which a higher refinement will abolish, as it has tattooing and nose-rings. With a conceptive imagination vigorous beyond any in his gencration, with a mastery of language equalled only by the greatest poets, he wants altogether the plastic imagination, the shaping faculty, which would have made him a poet in the highest sense. He is a preacher and a prophet, - anything you will, but an artist he is not, and never can be. It is always the knots and gnarls of the oak that he admires, never the perfect and balanced tree.

It is certainly more agreeable to be grateful for what we owe an author, than to blame him for what he cannot give us. But it is sometimes the business of a critic to trace faults of style and of thought to their root in character and temperament, - to show their necessary relation to, and dependence on, each other, - and to find some more trustworthy explanation than mere wantonness of will for the moral obliquities of a man so largely moulded 
and gifted as Mr. Carlyle. So long as he was merely an exhorter or dehorter, we were thankful for such eloquence, such humor, such vivid or grotesque images, and such splendor of illustration as only he could give; but when he assumes to be a teacher of moral and political philosophy, when he himself takes to compounding the social panaceas he has made us laugh at so often, and advertises noue as genuine but his own, we begin to inquire into his qualifications and his defects, and to ask ourselves whether his patent pill differs from others except in the larger amount of aloes, or has any better recommendation than the superior advertising powers of a mountebank of genius. Comparative criticism teaches us that moral and wsthetic defects are more nearly related than is commonly supposed. Had Mr. Carlyle been fitted out completely by nature as an artist, he would have had an ideal in his work which would have lifted his mind away from the muddier part of him, and trained him to the habit of seeking and seeing the harmony rather than the discord and contradiction of things. His innate love of the picturesque, (which is only another form of the sentimentalism he so scoffs at, perhaps as feeling it a weakness in himself,) once turned in the direction of character, and finding its chief satisfaction there, led him to look for that ideal of human nature in individual men which is but fragmentarily represented in the entire race, and is rather divined from the aspiration, forever disenchanted to be forever renewed, of the immortal part in us, than found in any example of actual achievement. A wiser temper would have found something more consoling than disheartening in the continual failure of men eminently endowed to reach the standard of this spiritual requirement, would perhaps have found in it an inspiring hint that it is mankind, and not special men, that are to be shaped at 
last into the image of God, and that the endless life of the generations may hope to come nearer that goal of which the short-breathed threescore years and ten fill too unhappily short.

But Mr. Carlyle has invented the Hero-cure, and all who recommend any other method, or see any hope of healing elsewhere, are either quacks and charlatans or their victims. His lively imagination conjures up the image of an impossible he, as contradictorily endowed as the chicf personage in a modern sentimental novel, and who, at all hazards, must not lead markind like a shepherd, but bark, bite, and otherwise worry them toward the fold like a truculent sheep-dog. If $\mathrm{Mr}$. Carlyle would only now and then recollect that men are men, and not sheep, - nay, that the farther they are from being such, the more well grounded our hope of one day making something better of them! It is indeed strange that one who riblues Will so highly in the greatest, should be blind to its infinite worth in the least of men ; nay, that he should so often seem to confound it with its irritable and purposeless counterfeit, Wilfulness. The natural impatience of an imaginative temperament, which conceires so vividly the beauty and desirableness of a nobler manhood and a diviner political order, makes him fret at the slow moral processes by which the All-Wise brings about his ends, and turns the very foolishmess of men to his praise and glory. Mr. Carlyle is for calling dorrn fire from Hearen whenerer he cannot readily lay his hand on the match-box. No doubt it is somewhat proroking that it should be so easy to build castles in the air, and so hard to find tenants for them. It is a singular intellectual phenomenon to see a man, who carlier in life so thoroughly appreciated the innate weakness and futile tendency of the "storm and thrust" period of German litcrature, constantly 
assimilating, as he grows older, more and more nearly to its principles and practice. It is no longer the sagacious and moderate Goethe who is his type of what is highest in human nature, but far rather some Gütz of the Iron Hand, some assertor of the divine legitimacy of Faustrecht. It is odd to conceive the fate of $\mathrm{Mr}$. Carlyle under the sway of any of his heroes, - how Cromwell would have scorned him as a babbler more long-winded than Prynne, but less clear and practical, - how Friedrich would have scoffed at his tirades as dummes Zeug not to be compared with the romances of Crébillon fils, or possibly have clapped him in a marching regiment as a fit subject for the cane of the sergeant. Perhaps something of Mr. Carlyle's irritability is to be laid to the account of his early schoolmastership at Ecclefechan. This great booby World is such a dull boy, and will not learn the lesson we have taken such pains in expounding for the fiftieth time. Well, then, if eloquence, if example, if the awful warning of other little boys who neglected their accidence and came to the gallows, if none of these avail, the birch at least is left, and we will try that. The dominie spirit has become every year more obtrusive and intolerant in Mr. Carlyle's writing; and the rod, instead of being kept in its place as a resource for desperate cases, has become the alpha and omega of all successful training, the one divinely-appointed means of human enlightenment and progress, - in short, the final hope of that absurd animal who fancies himself a little lower than the angels. Have we feebly taken it for granted that the distinction of man was reason? Never was there a more fatal misconception. It is in the gift of unreason that we are unenriably distinguished from the brutes, whose nobler privilege of instinct saves them from our blunders and our crimes.

But since Mr. Carlyle has become possessed with the 6 * 
hallucination that he is head-master of this huge boys' school which we call the world, his pedagogic birch has grown to the taller proportions and more ominous aspect of a gallows. His article on Dr. Francia was a panegyric of the halter, in which the gratitude of mankind is invoked for the self-appointed dictator who had discovered in Paraguay a tree more beneficent than that which produced the Jesuits' bark. Mr. Carlyle seems to be in the condition of a man who uses stimulants, and must increase his dose from day to day as the senses become dulled under the spur. He began by admiring strength of character and purpose, and the manly selfdenial which makes a humble fortune great by steadfast loyalty to duty. He has gone on till mere strength has become such washy weakness that there is no longer any titillation in it ; and nothing short of dowmight violence will rouse his nerves now to the needed excitement. At first he made out very well with remarkable men; then, lessening the water and increasing the spirit, he took to Heroes: and now he must have downright inhumanity, or the draught has no saror; - so he gets on at last to Kings, types of remorseless Force, who maintain the political views of Berserkers by the legal principles of Lynch. Constitutional monarchy is a failure, representative government is a gablle, democracy a birth of the bottomless pit; there is no hope for mankind except in getting themselves under a good driver who shall not spare the lash. And yet, unhappily for us, these drivers are providential births not to be contrived by any cunning of ours, and Friedrich II. is hitherto the last of them. Meanwhile the world's wheels have got fairly stalled in mire and other matter of every vilest consistency and most disgustful smell. What are we to do? Mr. Carlyle will not let us make a lever with a rail from the next fence, or call in the neighbors. That would be 
too commonplace and cowardly, too anarchical. No; he would have us sit down beside him in the slough, and shout lustily for Hereules. If that indispensable demigod will not or cannot come, we ean find a useful and instructive solace, during the intervals of shouting, in a hearty abuse of human nature, which, at the long last, is always to blame.

Since "Sirtor Resartus" Mr. Carlyle has done little but repeat himself with increasing emphasis and heightened shrillness. Warning has steadily heated toward denunciation, and remonstrance soured toward scolding. The image of the Tartar prayer-mill, which he borrowed from Richter and turned to such humorous purpose, might be applied to himself. The same phrase comes round and round, only the machine, being a little crankier, rattles more, and the performer is called on for a more risible exertion. If there be not something very like cant in Mr. Carlyle's later writings, then cant is not the repetition of a creed after it has become a phrase by the cooling of that white-hot conviction which once made it both the light and warmth of the soul. We do not mean intentional and deliberate cant, but neither is that which Mr. Carlyle denounces so energetically in his fellow-men of that conscious kind. We do not mean to blame him for it, but mention it rather as an interesting phenomenon of human nature. The stock of ideas which mankind has to work with is very limited, like the alphabet, and can at best have an air of freshness given it by new arrangements and combinations, or by application to new times and circumstances. Montaigne is but Ecclesiastes writing in the sixteenth century, Voltaire but Lucian in the eighteenth. Yet both are original, and so certainly is Mr. Carlyle, whose borrowing is mainly from his own former works. But he does this so often and so openly, that we may at least be sure that 
he ceased growing a number of years ago, and is a remarkable example of arrested development.

The cynicism, however, which has now become the prevailing temper of his mind, has gone on expanding with unhappy vigor. In Mr. Carlyle it is not, certainly, as in Swift, the result of personal disappointment, and of the fatal eye of an accomplice for the mean qualities by which power could be attained that it might be used for purposes as mean. It seems rather the natural corruption of his exuberant humor. Humor in its first analysis is a perception of the incongruous, and in its highest development, of the incongruity between the actual and the ideal in men and life. With so keen a sense of the ludicrous contrast between what men might be, nay, wish to be, and what they are, and with a vehement nature that demands the instant realization of his vision of a world altogether heroic, it is no wonder that Mr. Carlyle, always hoping for a thing and always disappointed, should become bitter. Perhaps if he expected less he would find more. Saul seeking his father's asses found himself turned suddenly into a king ; but Mr. Carlyle, on the lookout for a king, always seems to find the other sort of animal. He sees nothing on any side of him but a procession of the Lord of Nisrule, in gloomier moments, a Dance of Death, where ererything is either a parody of whatever is noble, or an aimless jig that stumbles at last into the amnihilation of the grave, and so passes from one nothing to another. Is a world, then, which buys and reads Mr. Carlyle's works distinguished only for its "fair, large ears" ? If he who has read and rememlered so much would only now and then call to mind the old proverb, Nec deus, nec lupus, sed homo! If he would only recollect that, from the days of the first grandfather, everybody has remembered a golden age behind him! 
The very qualities, it seems to us, which came so near making a great poet of Mr. Carlyle, disqualify him for the office of historian. The poet's concern is with the appearances of things, with their harmony in that whole which the imagination demands for its satisfaction, and their truth to that ideal nature which is the proper object of poetry. History, unfortunately, is very far from being ideal, still farther from an exclusive interest in those heroic or typical figures which answer all the wants of the epic and the drama and fill their utmost artistic limits. Mr. Carlyle has an unequalled power and vividness in painting detached scenes, in bringing out in their full relief the oddities or peculiarities of character; but he has a far feebler sense of those gradual changes of opinion, that strange communication of sympathy from mind to mind, that subtile influence of very subordinate actors in giving a direction to policy or action, which we are wont somewhat vaguely to call the progress of events. His scheme of history is purely an epical one, where only leading figures appear by name and are in any strict sense operative. He has no conception of the people as anything else than an element of mere brute force in political problems, and would sniff scornfully at that umpicturesque common-sense of the many, which comes slorly to its conclusions, no doubt, but compels obedicnce even from rulers the most despotic when once its mind is made up. His history of Frederick is, of course, a Fritziad ; but next to his hero, the cane of the drill-sergeant and iron ramrods appear to be the conditions which to his mind satisfactorily account for the result of the Seren Years War. It is our opinion, which subsequent erents seem to justify, that, had there not been in the Prussian people a strong instinct of nation. ality, Protestant nationality too, and an intimate convic tion of its advantages, the war might have ended quite 
otherwise. Frederick II. left the machine of war which he received from his father even more perfect than he found it, yet within a few years of his death it went to pieces before the shock of French armies animated by an idea. Again a few years, and the Prussian soldiery, inspired once more by the old national fervor, were victorious. Were it not for the purely picturesque bias of Mr. Carlyle's genius, for the necessity which his epical treatment lays upon him of always having a protagonist, we should be astonished that an idealist like him should have so little faith in ideas and so much in matter.

Mr. Carlyle's mamer is not so well suited to the historian as to the essayist. He is always great in single figures and striking episodes, but there is neither gradation nor continuity. He has extraordinary paticnce and conscientionsness in the gathering and sifting of his material, but is scornful of commonplace facts and characters, impatient of whaterer will not serve for one of his clever sketches, or group well in a more elaborate figurepiece. He sees history, as it were, by flashes of lightning. A single scene, whether a landscape or an interior, a single figure or a wild mol of men, whatever may be snatched by the eye in that instant of intense illumination, is minutely photographed upon the memory. Every tree and stone, almost every blade of grass ; every article of furniture in a room ; the attitude or cxpression, nay, the very buttons and shoe-ties of a principal figure; the gestures of momentary passion in a wild throng, everything leaps into vision under that sudden glare with a painful distinctness that leaves the retina quivering. The intervals are absolute darkness. Mr. Carlyle makes us acquainted with the isolated spot where we happen to be when the flash comes, as if by actual eyesight, but there is no possibility of a enmprehensive riew. No other writer compares with him for vividness. 
He is himsielf a witness, and makes us witnesses of whatever he describes. This is genius beyond a question, and of a very rare quality, but it is not history. He has not the cold-blooded impartiality of the historian; and while he entertains us, moves us to tears or laughter, makes us the unconscious captives of his ever-changeful mood, we find that he has taught us comparatively little. His imagination is so powerful that it makes him the contemporary of his characters, and thus his history seems to be the memoirs of a cynical humorist, with hearty likes and dislikes, with something of acridity in his partialities whether for or against, more keenly sensitive to the grotesque than the simply natural, and who enters in his diary, eren of what comes within the range of his own observation, only so much as amuses his fancy, is congenial with his humor, or feeds his prejudice. Mr. Carlyle's method is accordingly altogether pictorial, his hasty temper making narrative wearisome to him. In his Friedrich, for example, we get very little notion of the ciril administration of Prussia ; and when he comes, in the last volume, to his hero's dealings with civil reforms, he confesses candidly that it would tire him too much to tell us about it, even if he knew anything at all satisfactory himself.

Mr. Carlyle's historical compositions are wonderful prose poems, full of picture, incident, humor, and character, where we grow familiar with his conception of certain leading personages, and even of subordinate ones, if they are necessary to the scene, so that they come out living upon the stage from the dreary limbo of names; but this is no more history than the historical plays of Shakespeare. There is nothing in imaginative literature superior in its own way to the episode of Voltaire in the Fritziad. It is delicions in humor, masterly in minute characterization. We feel as if the principal victim (for 
we cannot help feeling all the while that he is so) of this mischievous genius had been put upon the theatre before us by some perfect mimic like Foote, who had studied his habitual gait, gestures, tones, turn of thought, costume, trick of feature, and rendered them with the slight dash of caricature necdful to make the whole composition tell. It is in such things that Mr. Carlyle is beyond all rivalry, and that we must go back to Shakespeare for a comparison. But the mastery of Shakespeare is shown perhaps more strikingly in his treatment of the ordinary than of the exceptional. His is the gracious equality of Nature herself. Mr. Carlyle's gift is rather in the representation than in the evolution of character; and it is a necessity of his art, therefore, to exaggerate slightly his heroic, and to caricature in like mamner his comic parts. His appreciation is less psychological than physical and external. Grimm relates that Garrick, riding once with Prérille, proposed to him that they should counterfeit drunkenness. They rode through Passy aceordingly, deceiving all who saw them. When beyond the town Préville asked how he had succeeted. "Excellently," said Giurrick, "as to your body; but your legs were not tipsy." Mr. Carlyle would be as exact in his observation of nature as the great actor, and would make us see a drunken man as well; but we doubt whether he could have conceived that unmatchable scene in Antony and Cleopatra, where the tipsiness of Lepidus pervades the whole metaphysical no less than the physical part of the triumvir. If his sympathies bore any proportion to his instinct for catching those traits which are the expression of character, but not character itself, we might have had a great historian in him instead of a history-painter. But that which is a main element in Mr. Carlyle's talent, and does perhaps more than anything else to make it effective, is a defect 
of his nature. The cynicism which renders him so entertaining precludes him from any just conception of men and their motives, and from any sane estimate of the relative importance of the events which concern them. We remember a picture of Hamon's, where before a Punch's theatre are gathered the wisest of mankind in rapt attention. Socrates sits on a front bench, absorbed in the spectacle, and in the corner stands Dante making entries in his note-book. Mr. Carlyle as an historian leaves us in somewhat such a mood. The world is a puppet-show, and when we have watched the play out, we depart with a half-comic consciousness of the futility of all human enterprise, and the ludicrousness of all man's action and passion on the stage of the world. Simple, kindly, blundering Oliver Goldsmith was after all wiser, and his Vicar, ideal as Hector and not less immortal, is a demonstration of the perennial beauty and heroism of the homelicst human nature. The cynical view is congenial to certain moods, and is so little inconsistent with original nobleness of mind, that it is not scldom the acetous fermentation of it ; but it is the view of the satirist, not of the historian, and takes in but a narrow are in the circumference of truth. Cynicism in itself is essentially disagreeable. It is the intellectual analogue of the truffle; and though it may be very well in giving a relish to thought for certain palates, it cannot supply the substance of it. Mr. Carlyle's cynicism is not that polished weariness of the outsides of life which we find in Ecclesiastes. It goes much deeper than that to the satisfactions, not of the body or the intellect, but of the very soul itself. It vaunts itself; it is noisy and aggressive. What the wise master puts into the mouth of desperate ambition, thwarted of the fruit of its crime, as the fitting expression of passionate sophistry, seems to have become an article of his creed. With him 
"Life is a tale

Told by an idiot, full of sound and fury, Signifying nothing."

He goes about with his Diogenes dark-lantern, professing to seek a man, but inwardly resolved to find a monkey. He loves to flash it suddenly on poor human nature in some ridiculous or degrading posture. He admires still, or keeps affirming that he admires, the doughty, silent, hard-working men who, like Cromwell, go honestly about their business; but when we come to his later examples, we find that it is not loyalty to duty or to an inward ideal of high-mindedness that he finds admirable in them, but a blind unquestioning vassalage to whomsoever it has pleased him to set up for a hero. He would fain replace the old feudalism with a spiritual counterpart, in which there shall be an obligation to soul-service. He who once popularized the word flunkey by ringing the rehement changes of his scorn upon it, is at last forced to conceive an ideal flunkerism to squire the hectoring Don Belianises of his fancy about the world. Failing this, his latest theory of Divine government seems to be the eudgel. Poets have sung all manner of vegetable loves; Petrarch has celebrated the laurel, Chancer the daisy, and Wordsworth the gallows-tree; it remained for the ex-pedagogue of Ecclefechan to become the volunteer laureate of the rod, and to imagine a world created and directed by a divine Dr. Busby. We cannot help thinking that Mr. Carlyle might have learned something to his adrantage by living a few years in the democracy which he scoff's at as heartily a priori as if it were the demagogism which Aristophanes derided from experience. The Hero, as MIr. Carlyle understands him, was a makeshift of the past ; and the ideal of manhood is to be found hereafter in free communities, where the state shall at lengtl sum up and exemplify in itself 
all those qualities which poets were forced to imagine and typify because they could not find them in the nctual world.

In the earlier part of his literary career, Mr. Carlylc was the denouncer of shams, the preacher up of sincerity, manliness, and of a living faith, instead of a droning ritual. He had intense convictions, and ho made disciples. With a compass of diction unequalled by any other public performer of the time, ranging as it did from the unbooked freshuess of the Scottish peasant to the most far-sought phrase of literary curiosity, with humor, pathos, and eloquence at will, it was no wonder that he found eager listeners in a world longing for a sensation, and forced to put up with the West-End gospel of "Pelham." If not a profound thinker, he had what was next best, - he felt profoundly, and his cry came out of the depths. The stern Calvinism of his early training was rekindled by his imagination to the old fervor of Wishart and Brown, and became a new phenomenon as he reproduced it subtilized by German transcendentalism and German culture. Imagination, if it lays hold of a Scotchman, possesses him in the old demoniac sense of the word, and that hard logical nature, if the Hebrew fire once gets fair headway in it, burns unquenchable as an anthracite coal-mine. But to ntilize these sacred heats, to employ them, as a literary man is always tempted, to keep the domestic pot a-boiling, - is such a thing possible? Only too possible, we fear; and Mr. Carlyle is an example of it. If the languid public long for a sensation, the excitement of making one becomes also a necessity of the successful author, as the intellectual nerres grow duller and the old inspiration that came unbidden to the bare garret grows shier and shier of the comfortable parlor. As he himself said thirty years ago of Edward Irving, "Un- 
consciously, for the most part in deep unconsciousness, there was now the impossibility to live neglected, - to walk on the quiet paths where alone it is well with us. Singularity must henceforth succeed singularity. O foulest Circean draught, thou poison of Popular Applause! madness is in thee and death; thy end is Bedlam and the grave." Mr. Carlyle won his first successes as a kind of preacher in print. His fervor, his oddity of manner, his pugnacious paradox, drew the crowd ; the truth, or, at any rate, the faith that underlay them all, brought also the fitter audience, though fewer. But the curse was upon him; he must attract, he must astonish. Thenceforth he has done nothing but revamp his telling things; but the oddity has become always odder, the paradoxes more paradoxical. No very large share of truth falls to the apprehension of any one man; let him keep it sacred, and beware of repeating it till it turn to falsehood on his lips by becoming ritual. Truth always has a berritching savor of newness in it, and novelty at the first taste recalls that original sweetness to the tongue; but alas for him who would make the one a substitute for the other! We seem to miss of late in Mr. Carlyle the old sincerity. He has become the purely literary man, less concerned about what he says than about how he shall say it to best advantage. The Muse should be the companion, not the guide, says he whom Mr. Carlyle has pronounced "the wisest of this generation." What wonld be a virtue in the poet is a vice of the most fatal kind in the teacher, and, alas that we should say it! the very Draco of shams, whose code contained no penalty milder than capital for the most harmless of them, has become at last something very like a sham himself. Mr. Carlyle continues to be a voice erying in the wilderness, but no longer a voice with any earnest conviction behind it. 
Hearing him rebuke us for being humbugs and impostors, we are inclined to answer, with the ambassador of Philip II., when his master reproached him with forgetting substance in ccremony, "Your Majesty forgets that you are only a ceremony yourself." And Mr. Carlyle's teaching, moreover, - if teaching we may call it, - belongs to what the great German, whose disciple he is, condemned as the "literature of despair." An apostle to the gentiles might hope for some fruit of his preaching; but of what avail an apostle who shouts his message down the mouth of the pit to poor lost souls, whom he can positively assure only that it is impossible to get out? Mr. Carlyle lights up the lanterns of his Pharos after the ship is already rolling between the tongue of the sea and the grinders of the reef. It is very brilliant, and its revolving flashes touch the crests of the breakers with an awful picturesqueness; but in so desperate a state of things, even Dr. Syntax might be pardoned for being forgetful of the picturesque. The Toryism of Scott sprang from love of the past ; that of Carlyle is far more dangerously infectious, for it is logically deduced from a deep disdain of human nature.

Browning has drawn a beautiful picture of an old king sitting at the gate of his palace to judge his people in the calm sunshine of that past which never existed outside a poet's brain. It is the sweetest of waking dreams, this of absolute power and perfect wisdom in one supreme ruler; but it is as pure a creation of human want and weakness, as clear a witness of mortal limitation and incompleteness, as the shoes of swiftness, the cloak of darkness, the purse of Fortunatus, and the elixir vitce. It is the natural refuge of imaginative temperaments impatient of our blunders and shortcomings, and, given a complete man, all would submit to the divine right of his despotism. But alas! to every the 
most fortunate human birth hobbles up that malign fairy who has been forcotten, with her fatal gift of imperfection! So fir as our experience has gone, it has been the very opposite of $\mathrm{Mr}$. ('irlyle's. Instead of finding men disloyal to their natural leader, nothing has ever seemed to us so touching as the glatness with which they follow him, when they are sure they have fomd him at last. But a natural leader of the ideal type is not to be looked for nisi dignus vindice nodus. The Divine Forethought hat been eruel in fumishing one for erery petty ocension, and thus thwarting in all inferior men that priceless gift of reason, to derelop which, and to make it one with free-will, is the highest use of our experience on earth. Mr. Carlyle was hard besteal and very far gone in his idolatry of mere pluck, when he was driven to choose Friedrich as a hero. A poet-and Mrr. Carlyle is nothing else - is unwise who yokes Pegasus to a prosaic theme which no force of wing cim lift from the dull earth. Charlemagne would have been a wiser choice, far enough in the past for ideal treatment, more manifestly the sienfried of Anarchy, and in his rude way the refommler of that empire which is the ideal of despotism in the Western world.

Friedrich was doubtless a remarkable mam, but surely very far below any lofty standard of heroic greatness. The was the last of the European kings who could look upon his kingdom as his private patrimony ; and it was this estate of his, this piece of property, which he so olstinately and suceessfully defenderl. He had no idea of comtry as it wis mderstood by an ancient Greek or lioman, as it is understood by a modern Englishman or Anerican ; and there is something almost pitiful in seeing a man of genius like Mr. Carlyle fighting painfully orer again those battles of the last century which settled nothing but the continuance of the Prussian monarehy, 
while he saw only the "burning of a dirty chimney" in the war which a great people was waging under his very eyes for the idea of nationality and orderly magistrature, and which fixed, let us hope forever, a boundary-line on the map of history and man's advancement toward selfconscious and responsible freedom. The true historical genius, to our thinking is that which can see the nobler meaning of events that are near him, as the true poet is he who detects the divine in the casual; and we somewhat suspect the depth of his insight into the past, who cannot recognize the godlike of to-day under that disguise in which it always visits us. Shall we hint to Mr. Carlyle that a man may look on an heroic age, as well as an heroic master, with the eyes of a valct, as misappreciative certainly, though not so ignoble?

What Goethe says of a great poet, that he nuust be a citizen of his age as well as of his country, may be said inversely of a great king. He should be a citizen of his country as well as of his age. Friedrich was certainly the latter in its fullest sense; whether he was, or could hare been, the former, in any sense, may be doubted. The man who spoke and wrote French in preference to his mother-tongue, who, dying when Goethe was already drawing toward his fortieth year, Schiller toward his thirtieth, and Lessing had been already five years in his grave, could yet see nothing but barbarism in German literature, had little of the old Teutonic fibre in his nature. The man who pronounced the Nibelungen Lied not worth a pinch of priming, had little conception of the power of heroic traditions in making heroic men, and especially in strengthening that instinct made up of so many indistinguishable associations which we call love of country. Charlemagne, when he caused the old songs of his people to be gathered and written down, showed a truer sense of the sources of national feeling and a 
deeper political insight. This want of sympathy points to the somewhat narrow limits of Friedrich's nature. In spite of Mr. Carlyle's adroit statement of the ease, and the whole book has an air of being the plea of a masterly advocate in mitigation of sentence, we feel that his hero was essentially hard, narrow, and selfish. His popularity will go for little with any one who has studied the trifling and often fibulous elements that make up that singular compound. A bluntness of speech, a shabby uniform, a frugal camp equipage, a timely familiarity, may make a man the firrorite of an army or a nation, - above all, if he have the knack of suceess. Moreover, popularity is much more easily won from above downward, and is bought at a better bargain hy kings and generals than by other men. We doubt if Friedrich would have been liked as a private person, or eren as an unsuccessful ling. He apparently attached very few people to himself, fewer eren than his brutal old Squire Western of a father. His sister Wilhelmina is perhaps an exception. We say perhaps, for we do not know how much the heroie part he was called on to play had to do with the matter, and whether sisterly pride did not pass even with herself for sisterly affection. Moreover she was far from him; and Mr. Carlyle waves aside, in his generous fashion, some rather keen comments of hers on her brother's character when she visited Berlin after he had become king. Indeed, he is apt to deal rather contemptuously with all adverse criticism of his hero. We sympathize with his impulse in this respect, agreeing heartily as we do in Chaucer's scorn of those who "gladlie demen to the baser end" in such matters. But we are not quite sure if this be a safe method with the historian. He must doubtless be the friend of his hero if he would understand him, but he must be more the friend of truth if he would understand 
history. Mr. Carlyle's passion for truth is intense, as befits his temper, but it is that of a lover for his mistress. He would have her all to himself, and has a lover's conviction that no one is able, or even fit, to appreciate her but himself. He does well to despise the tittle-tattle of vulgar minds, but surely should not ignore all testimony on the other side. For ourselves, we think it not unimportant that Goethe's friend Kinebel, a man not incapable of admiration, and who had served a dozen years or so as an officer of Friedrich's guard, should have bluntly called him "the tyrant."

Mr. Carlyle's history traces the family of his hero down from its beginnings in the picturesque chiaro-scuro of the Middle Ages. It was an able and above all a canny house, a Scotch version of the word able, which implies thrift and an eye to the main chance, the said main chance or chief end of man being altogether of this world. Friedrich, inheriting this family faculty in full measure, was driven, partly by ambition, partly by necessity, to apply it to war. He did so, with the success to be expected where a man of many expedients has the good luck to be opposed by men with few. $\mathrm{He}$ adds another to the many proofs that it is possible to be a great general without a spark of that divine fire which we call genius, and that good fortune in war results from the same prompt talent and unbending temper which lead to the same result in the peaceful professions. Friedrich had certainly more of the temperament of genius than Narlborough or Wellington; but not to go beyond modern instances, he does not impress us with the massive breadth of Napoleon, nor attract us with the climbing ardor of Turenne. To compare him with Alexander or Cæesar were absurd. The kingship that was in him, and which won Mr. Carlyle to be his biographer, is that of will merely, of rapid and relentless 
command. For organization he had a masterly talent; but he could not apply it to the arts of peace, both be. cause he wanted experience and because the rash decision of the battle-field will not serve in matter's which are governed by natural laws of growth. He scems, indeed, to have had a coarse, soldier's contempt for all civil distinction, altogether unworthy of a wise king; or even of a prudent one. He confers the title of Hofrath on the husband of a woman with whom his General Walrave is living in what Mr. Carlyle justly calls "brutish polygamy," and this at Walrave's request, on the ground that "a gencral's drab ought to have a handle to her 1:ame." Mr. Carlyle murmurs in a mild parenthesis that "we rather regret this"! (Vol. III. p. 559.) This is his usual way of treating unpleasant matters, sidling by with a deprecating shrug of the shoulders. Not that he ever wilfully suppresses anything. On the contrary, there is no greater proof of his genius than the way in which, while he secms to paint a character with all its disagreeable traits, he contrives to win our sympathy for it, nay, almost our liking. This is conspicuously true of his portrait of Friedrich's father; and that he does not succeed in making Friedrich himself attractive is a strong argument with us that the fault is in the subject and not the artist.

The book, we believe, has been comparatively unsuccessful as a literary venture. Nor do we wonder at it. It is disproportionately long, and ton much made up of those descriptions of battles to read which seems even more difficult than to have won the victory itself, more disheartening than to have suffered the defeat. To an American, also, the warfare secmed Liliputian in the presence of a conflict so much larger in its proportions and significant in its results. The interest, moreover, flags decidedly toward the close, where the reader cannot 
help feeling that the author loses breath somewhat painfully under the effort of so prolonged a course. Mr. Carlyle has evidently devoted to his task a labor that nay be justly called prodigious. Not only has he sifted all the German histories and memoirs, but has risited every battle-ficld, and describes them with an eye for country that is without rival among historians. The book is evidently an abridgment of even more abundant collections, and yet as it stands the matter orerburdens the work. It is a bundle of lively episodes rather than a continuous narrative. In this respect it contrasts oddly with the concinnity of his own earlier Life of Schiller. But the episodes are lively, the humor and pathos spring from a profound nature, the sketches of character are masterly, the seizure of every picturesque incident infallible, and the literary judgments those of a thorough scholar and critic. There is, of course, the usual amusing objurgation of Dryasdust and his rubbishheaps, the usual assumption of omniscience, and the usual certainty of the lively French lady of being always in the right; yet we camnot help thinking that a little of Dryasdust's plodding exactness would have saved Fouquet eleven years of the imprisonment to which $\mathrm{Mr}$. Carlyle condemns him, would have referred us to St. Simon rather than to Voltaire for the character of the brothers Belle-Ile, and would have kept clear of a certain ludicrous etymology of the name Antwerp, not to mention some other trifling slips of the like nature. In conclusion, after saying, as honest crities must, that "The History of Friedrich II. called Frederick the Great" is a book to be read in with more satisfaction than to be read through, after declaring that it is open to all manner of criticism, especially in point of moral purpose and tendency, we must admit with thankfulness, that it has the one prime merit of being the work 
of a man who has every quality of a great poet except that supreme one of rhythm which shapes both matter and manner to harmonious proportion, and that where it is good, it is good as only genius knows how to be.

With the gift of song, Carlyle would have been the greatest of epic poets since Homer. Without it, to modulate and harmonize and bring parts into their proper relation, he is the most amorphous of humorists, the most shining aratar of whim the world has ever seen. Beginning with a hearty contempt for shams, he has come at length to believe in brute force as the only reality, and has as little sense of justice as Thackeray allowed to women. We say brute force because, though the theory is that this force should be directed by the supreme intellect for the time being, yet all inferior wits are treated rather as obstacles to be contemptuously shoved aside than as ancillary forces to be conciliated through their reason. But, with all deductions, he remains the profoundest critic and the most dramatic imagination of modern times. Never was there a more striking example of that ingenium perfervidum long ago said to be characteristic of his countrymen. His is one of the natures, rare in these latter centuries, capable of rising to a white heat; but once fairly kindled, he is like a threc-decker on fire, and his shotted guns go off, as the glow reaches them, alike dangerous to friend or foe. Though he seems more and more to confound material with moral success, yet there is always something wholesome in his unswerving loyalty to reality, as he understands it. History, in the true sense, he does not and camnot write, for he looks on mankind as a herd without volition, and without moral force; but such rivid pictures of events, such living conceptions of character, we find nowhere else in prose. The figures of most historiuns seem like dolls stuffed with bran, whose whole sub. 
stance runs out through any hole that criticism may tear in them, but Carlyle's are so real in comparison, that, if you prick them, they bleed. He seems a little woaried, here and there, in his Friedrich, with the multiplicity of detail, and does his filling-in rather shabbily; but he still remains in his own way, like his hero, the Only, and such cpisodes as that of Voltaire would make the fortune of any other writer. Though not the safest of guides in politics or practical philosophy, his value as an inspirer and awakener camnot be over-estimated. It is a power which belongs only to the highest order of minds, for it is none but a divine fire that can so kindle and irradiate. The debt due him from those who listened to the teachings of his prime for revealing to them what sublime reserves of power even the humblest may find in manliness, sincerity, and self-reliance, can be paid with nothing short of reverential gratitude. As a purifier of the sources whence our intellectual inspiration is drawn, his influence has been second only to that of Wordsworth, if even to his. 


\section{ABRAHAM LINCOLN 。}

1864.

THERE have been many painful crises since the impatient vanity of South Carolina hurried ten prosperous Commonwealths into a crime whose assured retribution was to leave them either at the mercy of the nation they had wronged, or of the anarchy they had summoned but could not control, when no thoughtful American opened his morning paper without dreading to find that he had no longer a country to love and honor. Whatever the result of the convulsion whose first shocks were begimning to be felt, there would still be enough square miles of earth for elbow-room ; but that ineffable sentiment made up of memory and hope, of instinct and tradition, which swells every man's heart and shapes his thought, though perhaps never present to his consciousness, would be gone from it, leaving it common earth and nothing more. Men might gather rich crops from it, but that ideal harvest of priceless associations would be reaped no longer; that fine virtue which sent up messages of courage and security from every sod of it would have evaporated beyond recall. We should be irrevocably cut off from our past, and be forced to splice the ragrged ends of our lives upon whatever new conditions chance might leave dangling for us.

We confess that we had our doubts at first whether the patriotism of our people were not too narrowly pro. vincial to embrace the proportions of national peril 
ITe felt an only too natural distrust of immense public meetings and enthusiastic cheers.

That a reaction should follow the holiday enthusiasm with which the war was entered-on, that it should follow soon, and that the slackening of public spirit should be proportionate to the previous over-tension, might well be foreseen by all who had studied human nature or history. Men acting gregariously are always in extremes; as they are one moment capable of higher courage, so they are liable, the next, to baser depression, and it is often a matter of chance whether numbers shall multiply confidence or discouragement. Nor does deception lead more surely to distrust of men, than selfdeception to suspicion of principles. The only faith that wears well and holds its color in all weathers is that which is woven of conviction and set with the sharp mordant of experience. Enthusiasm is good material for the orator, but the statesman needs something more durable to work in, - must be able to rely on the deliberate reason and consequent firmness of the people, without which that presence of mind, no less essential in times of moral than of material peril, will be wanting at the critical moment. Would this fervor of the Free States hold out? Was it kindled by a just fecling of the value of constitutional liberty? Had it body enough to withstand the inevitable dampening of checks, reverses, delays? Had our population intelligence enough to comprehend that the choice was between order and anarchy, between the equilibrium of a government by law and the tussle of misrule by promunciamiento? Could a war be maintained without the ordinary stimulus of hatred and plunder, and with the impersonal loyalty of principle? These were serions questions, and with no precedent to aid in answering them.

At the beginning of the war there was, indeed, occa- 
sion for the most anxious apprehension. A President known to be infected with the political heresies, and suspected of sympathy with the treason, of the Southern conspirators, had just surrendered the reins, we will not say of power, but of chaos, to a successor known only as the representative of a party whose leaders, with long training in opposition, had none in the conduct of affairs; an empty treasury was called on to supply resources beyond precedent in the history of finance; the trees were yet growing and the iron unmined with which a navy was to be built and armored; officers without discipline were to make a mob into an army; and, above all, the public opinion of Europe, echoed and reinforced with every vague hint and every specious argument of despondency by a powerful faction at home, was either contemptuously sceptical or actively hostilc. It would be hard to over-estimate the force of this latter element of disintegration and discouragement among a people where every citizen at home, and every soldier in the field, is a reader of newspapers. The pedlers of rumor in the North were the most effective allies of the rebellion. A nation can be liable to no more insidious treachery than that of the telegraph, sending hourly its electric thrill of panic along the remotest nerves of the community, till the excited imagination makes every real danger loom heightened with its unreal double.

And even if we look only at more palpable difficulties, the problem to be solved by our eivil war was so vast, both in its immediate relations and its future consequences; the conditions of its solution were so intricate and so greatly dependent on incalculable and uncontrollable contingencies; so many of the data, whether for hope or fear, were, from their novelty, incapable of arrangement under any of the categories of historical precedent, that there were moments of crisis when the 
firmest believer in the strength and sufficiency of the democratic theory of government might well hold his breath in vague apprehension of disaster. Our teachers of political philosophy, solemnly arguing from the precedent of some petty Grecian, Italian, or Flemish city, whose long periods of aristocracy were broken now and then by awkward parentheses of mob, had always tanght us that democracies were incapable of the sentiment of loyalty, of concentrated and prolonged effort, of far-reaching conceptions; were absorbed in material interests; impatient of regular, and much more of exceptional restraint; had no natural nucleus of gravitation, nor any forces but centrifugal ; were always on the verge of civil war, and slunk at last into the natural almshouse of bankrupt popular government, a military despotism. Here was indeed a dreary outlook for persons who knew democracy, not by rubbing shoulders with it lifelong, but merely from books, and America only by the report of some fellow-Briton, who, having eaten a bad dinner or lost a carpet-bag here, had written to the Times demanding redress, and drawing a mournful inference of democratic instability. Nor were men wanting among ourselves who had so steeped their brains in London literature as to mistake Cockneyism for European culture, and contempt of their country for cosmopolitan breadth of view, and who, owing all they had and all they were to democracy, thought it had an air of highbreeding to join in the shallow epicedium that our bubble had burst.

But beside any disheartening influences which might affect the timid or the despondent, there were reasons enough of settled gravity against any over-confidence of hope. A war - which, whether we consider the expanse of the territory at stake, the hosts brought into the field, or the reach of the principles involved, may fairly be 
reckoned the most momentous of modern times - was to be waged by a people divided at home, unnerved by fifty years of peace, under a chief magistrate without experience and without reputation, whose every moasure was sure to be cumningly hampered by a jealous and unscrupulous minority, and who, while dealing with unheard-of complications at home, must soothe a hostile neutrality abroad, waiting only a pretext to become war. All this was to be done without warning and without preparation, while at the same time a social revolution was to be accomplished in the political condition of four millions of people, by softening the prejudices, allaying the fears, and gradually obtaining the co-operation, of their unwilling liberators. Surely, if ever there were an occasion when the heightened imagination of the historian might see Destiny visibly intervening in human affairs, here was a knot worthy of her shears. Never, perhaps, was any system of government tried by so continunus and searching a strain as ours during the last three years; never has any shown itself stronger; and never could that strength be so directly traced to the virtue and intelligence of the people, - to that general enlightemment and prompt efficiency of public opinion possible only under the influence of a political framework like our own. We find it hard to understand how even a foreigner should be blind to the grandeur of the combat of ideas that has been going on here, - to the heroic energy, persistency, and self-reliance of a nation proving that it knows how much dearer greatness is than mere power; and we own that it is impossible for us to conceive the mental and moral condition of the American who does not feel his spirit braced and heightened by being even a spectator of such qualities and achievements. That a steady purpose and a definite aim have been giren to the jarring forces which, at the beginning 
of the war, spent themselves in the discussion of schemes which could only become operative, if at all, after the war was over; that a popular excitement has been slowly intensified into an earnest national will; that a somewhat impracticahle moral sentiment has been made the unconscious instrument of a practical moral end ; that the treason of corert enemies, the jealousy of rivals, the unwise zeal of friends, have been made not only useless for mischief, but even useful for good ; that the conscientious sensitiveness of England to the horrors of civil conflict has been prevented from complicating a domestic with a foreign war; - all these results, any one of which might suffice to prove greatness in a ruler, have been mainly due to the good sense, the goodhumor, the sagacity, the large-mindedness, and the unselfish honesty of the unknown man whom a blind fortune, as it seemed, had lifted from the crowd to the most dangerous and difficult eminence of modern times. It is by presence of mind in untried emergencies that the native metal of a man is tested; it is by the sagacity to see, and the fearless honesty to admit, whatever of truth there may be in an adverse opinion, in order more convincingly to expose the fallacy that lurks behind it, that a reasoner at length gains for his mere statement of a fact the force of argument; it is by a wise forecast which allows hostile combinations to go so far as by the inevitable reaction to become elements of his own power, that a politician proves his genius for state-craft; and especially it is by so gently guiding public sentiment that he seems to follow it, by so yiclding doubtful points that he can be firm without sceming obstinate in essential ones, and thus gain the advantages of compromise without the weakness of concession; by so instinctively comprehending the temper and prejudices of a people as to make them gradually conscious of the superior wisdom 
of his freedom from temper and prejudice, - it is by qualities such as these that a magistrate shows himself worthy to be chief in a commonwealth of freemen. And it is for qualities such as these that we firmly believe History will rank Mr. Lincoln among the most prudent of statesmen and the most successful of rulers. If we wish to appreciate him, we have only to conceive the inevitable chaos in which we should now be weltering, had a weak man or an unwise one been chosen in his stead.

"Bare is back," says the Norse prorerb, "without brother behind it"; and this is, by analogy, true of an elective magistracy. The hereditary ruler in any critical emergency may reckon on the inexhaustible resources of prestige, of sentiment, of superstition, of dependent interest, while the new man must slowly and painfully create all these out of the unwilling material around him, by superiority of character, by patient singleness of purpose, by sagacious presentiment of popular tendencies and instinctive sympathy with the national character. Mr. Lincoln's task was one of peculiar and exceptional difficulty. Long habit had accustomed tho American people to the notion of a party in power, and of a President as its creature and organ, while the more vital fact, that the executive for the time being represents the alstract idea of government as a permanent principle superior to all party and all private interest, had gradually become unfamiliar. They had so long seen the public policy more or less directed by views of party, and often even of personal advantage, as to bf. ready to suspect the motives of a chief magistrate com. pelled, for the first time in our history, to feel himself the head and hand of a great nation, and to act upon the fundamental maxim, laid down by all publicists, that the first duty of a government is to defend and maintain its own existence. Accordingly, a powerful 
weapon seemed to be put into the hands of the opposition by the necessity under which the administration found itself of applying this old truth to new relations. Nor were the opposition his only nor his most dangerous opponents.

The Republicans had carried the country upon an issue in which ethics were more directly and visibly mingled with politics than usual. Their leader's were trained to a method of oratory which relied for its effect rather on the moral sense than the understanding. Their arguments were drawn, not so much from experience as from general principles of right and wrong. When the war came, their system continued to be applicable and effective, for here again the reason of the people was to be reached and kindled through their sentiments. It was one of those periods of excitement, gathering, contagious, universal, which, while they last, exalt and clarify the minds of men, giving to the mere words country, human rights, democracy, a meaning and a force beyond that of sober and logical argument. They were convictions, maintained and defended by the supreme logic of passion. That penetrating fire ran in and roused those primary instincts that make their lair in the dens and caverns of the mind. What is called the great popular heart was awakened, that indefinable something which may be, according to circumstances, the highest reason or the most brutish unreason. But enthusiasm, once cold, can never be warmed over into anything better than cant, - and phrases, when once the inspiration that filled them with beneficent power has elbed away, retain only that semblance of meaning which enables them to supplant reason in hasty minds. Among the lessons taught by the French Rerolution there is none sadder or more striking than this, that you may make everything else out of the passions of men 
except a political system that will work, and that there is nothing so pitilessly and unconsciously cruel as sincerity formulated into dogma. It is always demoralizing to extend the domain of sentiment over questions where it has no legitimate jurisdiction; and perhaps the sererest strain upon Mr. Lincoln was in resisting a tendency of his own supporter's which chimed with his own private desires while wholly opposed to his convictions of what would be wise policy.

The change which three years have brought about is too remarkable to be passed over without comment, too weighty in its lesson not to be laid to heart. Never did a President enter upon office with less means at his command, outside his own strength of heart and steadiness of understanding, for inspiring confidence in tho people, and so winning it for himself, than Mr. Lincoln. All that was known of him was that he was a good stump-speaker, nominated for his revilability, - that is, because he had no history, - and chosen by a party with whose more extreme opinions he was not in sympathy. It might well he feared that a man past fifty, against whom the ingenuity of hostile partisans could rake up no accusation, must be lacking in manliness of character, in decision of principle, in strength of will; that a man who was at best only the representative of a party, and who yet did not fairly represent even that, would fail of political, much more of popular, support. And certainly no one ever entered upon office with so few resources of power in the past, and so many materials of weakness in the present, as Mr. Lincoln. Even in that half of the Union which acknowledged him as President, there was a large, and at that time dangerous minority, that hardly admitted his claim to the office, and even in the party that elected him there was also a large minority that suspected him of being secretly a 
communicant with the church of Laodicea. All that he did was sure to be virulently attacked as ultra by one side; all that he left undone, to be stigmatized as proof of lukewarmness and backsliding by the other. Meanwhile he was to carry on a truly colossal war by means of both; he was to disengage the country from diplomatic entanglements of unprecedented peril undisturbed by the help or the hinderance of either, and to win from the crowning dangers of his administration, in the confidence of the people, the means of his safety and their own. He has contrived to do it, and perhaps none of our Presidents since Washington has stood so firm in the confidence of the people as he does after three years of stormy administration.

Mr. Lincoln's policy was a tentative one, and rightly so. He laid down no programme which must compel him to be either inconsistent or unwise, no cast-iron theorem to which circumstances must be fitted as they rose, or else be useless to his ends. He seemed to have chosen Mazarin's motto, Le temps et moi. The moi, to be sure, was not very prominent at first; but it has grown more and more so, till the world is beginning to be persuaded that it stands for a character of marked individuality and capacity for affairs. Time was his prime-minister, and, we began to think, at one period, his general-in-chief also. At first he was so slow that he tired out all those who see no evidence of progress but in blowing up the engine; then he was so fast, that he took the breath away from those who think there is no getting on safely while there is a spark of fire under the boilers. God is the only being who has time enough; but a prudent man, who knows how to seize occasion, can commonly make a shift to find as much as he needs. Mr. Lincoln, as it seems to us in reviewing his career, though we have sometimes in our impatience thought 
otherwise, has always waited, as a wise man should, till the right moment brought up all his reserves. Semper nocuit differre paratis, is a sound axiom, but the really efficacious man will also be sure to know when he is not ready, and be firm against all persuasion and reproach till he is.

One would be apt to think, from some of the criticisms made on Mrr. Lincoln's course by those who mainly agree with him in principle, that the chicf object of a statesman should be rather to proclaim his adhesion to certain doctrines, than to achieve their triumph by quietly accomplishing his ends. In our opinion, there is no more unsafe politician than a conscientiously rigid doctrinaire, nothing more sure to end in disaster than a theoretic scheme of policy that admits of no pliability for contingencies. True, there is a popular image of an impossible He, in whose plastic hands the submissive destinies of mankind become as wax, and to whose commanding necessity the tonghest facts yield with the graceful pliancy of fiction; but in real life we commonly find that the men who control circumstances, as it is called, are those who have learned to allow for the influence of their eddies, and have the nerve to turn them to account at the happy instant. Mr. Lincoln's perilous task has been to carry a rather shaky raft through the rapids, making fast the umrulier logs as he could snatch opportunity, and the country is to be congratulated that he did not think it his duty to run straight at all hazards, but cautionsly to assure himself with his setting-pole where the main current was, and keep steadily to that. $\mathrm{He}$ is still in wild water, but we have faith that his skill and sureness of eye will bring him out right at last.

A curious, and, as we think, not inapt parallel, might be drawn between Mr. Lineoln and one of the most. striking figures in modern history, - Henry IV. of 
France. The career of the latter may be more picturesque, as that of a daring captain always is ; but in all its vicissitudes there is nothing more romantic than that sudden change, as by a rub of Aladdin's lamp, from the attorney's office in a country town of Illinois to the helm of a great nation in times like these. The analogy between the characters and circumstances of the two men is in many respects singularly close. Succeeding to a rebellion rather than a crown, Henry's chief material dependence was the Huguenot party, whose doctrines sat upon him with a looseness distasteful certainly, if not suspicious, to the more fanatical among them. King only in name over the greater part of France, and with his capital barred against him, it yet gradually became clear to the more far-sceing even of the Catholic party that he was the only centre of order and legitimate authority round which France could reorganize itself. While preachers who held the divine right of kings made the churches of Paris ring with declamations in favor of democracy rather than submit to the heretic dog of a Béarnois, - much as our soi-discent Democrats have lately been preaching the divine right of slavery, and denouncing the heresies of the Declaration of Independence, - Henry bore both partics in hand till he was convinced that only one course of action could possibly combine his own interests and those of France. Meanwhile the Protestants believed somewhat doubtfully that he was theirs, the Catholics hoped somewhat doubtfully that he would be theirs, and Henry himself turned aside remonstrance, advice, and curiosity alike with a jest or a proverb (if a little high, he liked them none the worse), joking continually as his manner was. We have seen Mr. Lincoln contemptuously compared to Sancho Panza by persons incapable of appreciating one of the deepest pieces of wisdom in the profoundest romance 
ever written; namely, that, while Don Quixote was incomparable in theoretic and ideal statesmanship, Sancho, with his stock of proverbs, the ready money of human experience, made the best possible practical governor. Henry IV. was as full of wise saws and modern instances as Mr. Lincoln, but beneath all this was the thoughtful, practical, humane, and thoroughly earnest man, around whom the fragments of France were to gather themselves till she took her place again as a planet of the first magnitude in the European system. In one respect Mr. Lincoln was more fortunate than Henry. However some may think him wanting in zeal, the most finatical can find no taint of apostasy in any measure of his, nor can the most bitter charge him with being influenced by motives of personal interest. The leading distinction between the policies of the two is one of circumstances. Henry went orer to the nation; Mr. Lincoln has steadily drawn the nation over to him. One left a united France; the other, we hope and believe, will leave a remited America. TVe leave our readers to trace the further points of difference and resemblance for themsclves, merely suggesting a general similarity which has often occurred to us. One only point of melancholy interest we will allow ourselves to touch upon. That Mr. Lincoln is not handsome nor elegant, we learn from certain English tourists who would consider similar revelations in regard to Queen Victoria as thoroughly American in their want of bienséance. It is noconcern of ours, nor does it affect his fitness for the high place he so worthily occupies; but he is certainly as fortumate as Henry in the matter of good lowks, if we may trust contemporary eridence. Mr. Lincoln has also been reproached with Americanism by some not unfriendly British critics; but, with all deference, we cannot say that we like him any the worse for 
it, or see in it any reason why he should gevern Americans the less wisely.

People of more sensitive organizations may be shocked, but we are glad that in this our true war of independence, which is to free us forever from the Old World, we have had at the head of our affairs a man whom America made, as God made Adam, out of the very earth, unancestried, unprivileged, unknown, to show us how much truth, how much magnanimity, and how much statecraft await the call of opportunity in simple manhood when it believes in the justice of God and the worth of man. Conventionalities are all very well in their proper place, but they shrivel at the touch of nature like stubble in the fire. The genius that sways a nation by its arbitrary will seems less august to us than that which multiplies and reinforces itself in the instincts and convictions of an entire people. Autocracy may have something in it more melodramatic than this, but falls far short of it in human value and interest.

Experience would have bred in us a rooted distrust of improvised statesmanship, eren if we did not believe politics to be a science, which, if it cannot always command men of special aptitude and great powers, at least demands the long and steady application of the best powers of such men as it can command to master even its first principles. It is curious, that, in a country which boasts of its intelligence, the theory should be so generally held that the most complicated of human contrivances, and one which every day becomes more complicated, can be worked at sight by any man able to talk for an hour or two without stopping to think.

Mr. Lincoln is sometimes claimed as an example of a ready-made ruler. But no case could well be less in point; for, besides that he was a man of such fair-mindedness as is always the raw material of wisdom, he had 
in his profession a training precisely the opposite of that to which a partisan is subjected. His experience as a lanyer compelled him not only to see that there is a principle underlying every phenomenon in human affairs, but that there are always two sides to every question, both of which must be fully understood in order to understand either, and that it is of greater advantage to an adrocate to appreciate the strength than the weakness of his antagonist's position. Nothing is more remarkable than the unerring tact with which, in his delate with Mr. Douglas, he went straight to the reason of the question; nor have we ever had a more striking lesson in political tactics than the fict, that, opposed to a man exceptionally adroit in using popular prejudice and bigotry to his purpose, exceptionally umscrupulous in appealing to those baser motives that turn a meeting of citizens into a mob of harloarians, he should yet have won his case before a jury of the people. Mr. Lincoln was as far as possible from an impromptu politician. His wisdom was made up of a knowledge of things as well as of men; his sagacity resulted from a clear perception and homest acknowledgment of difficulties, which enabled him to see that the only durable triumph of political opinion is based, not on any abstract right, but upon so much of justice, the highest attainable at any given moment in human affairs, as may be had in the balance of mutual concession. Doubtless he had an ideal, but it was the jileal of a practical statesman, - to aim at the best, and to take the next best, if he is lucky enough to get eren that. His slow, but singularly masculine, intelligence taught him that precedent is only another name for embodiel experience, and that it counts for even more in the guidance of communities of men than in that of the individual life. He was not a man who held it good public economy to pull down on the mere 
shance of rebuilding better. Mr. Lincoln's faith in God was qualified by a very well-founded distrust of the wisdom of man. Perhaps it was his want of self-confidence that more than anything else won him the unlimited confidence of the people, for they felt that there would be no need of retreat from any position he had deliberately taken. The cautious, but steady, advance of his poliey during the war was like that of a Roman army. He left behind him a firm road on which public confidence could follow; he took America with him where he went; what he gained he occupied, and his advanced posts became colonies. The very homeliness of his genius was its distinction. His kingship was conspicuous by its workday homespun. Never was ruler so absolute as he, nor so little conscious of it; for he was the incarnate common-sense of the people. With all that tenderness of nature whose sweet sadness touched whoever saw him with something of its own pathos, there was no trace of sentimentalism in his speech or action. He seems to have had but one rule of conduct, always that of practical and successful politics, to let himself be guided by events, when they were sure to bring him out where he wished to go, though by what seemed to unpractical minds, which let go the possible to grasp at the desirable, a longer road.

Undoubtedly the highest function of statesmanship is by degrees to accommodate the conduct of communities to ethical laws, and to subordinate the conflicting self-interests of the day to higher and more permanent concerns. But it is on the understanding, and not on the sentiment, of a nation that all safe legislation must be based. Voltaire's saying, that " a consideration of petty circumstances is the tomb of great things," may be true of individual men, but it certainly is not true of governments. It is by a multitude of such considerations, each 
in itself trifling, but all together weighty, that the framers of policy can alone divine what is practicable and therefore wise. The imputation of inconsistency is one to which every sound politician and every honest thinker must sooner or later subject himself. The foolish and the dead alone never change their opinion. The course of a great statesman resembles that of navigable rivers, avoiding immovable obstacles with noble bends of concession, seeking the broad levels of opinion on which men soonest settle and longest dwell, following and marking the almost imperceptible slopes of national tendency, jet always aiming at direct advances, always recruited from sources nearer hearen, and sometimes bursting open paths of progress and fruitful human commerce through what seem the eternal barriers of both. It is loyalty to great ends, even though forced to combine the small and opposing motives of selfish men to accomplish them; it is the anchored cling to solid principles of duty and action, which knows how to swing with the tide, but is never carried away by it, — that we demand in public men, and not simeness of policy, or a conscientious persistency in what is impracticable. For the impracticable, however theoretically enticing, is always politically unwise, sound statesmanship being the application of that prudence to the public business which is the safest guide in that of private men.

No doubt slavery was the most delicate and embarrassing question with which NIr. Lincoln was called on to deal, and it was one which no man in his position, whatever his opinions, could evade; for, though he might withstand the clamor of partisans, he must sooner or later yield to the persistent importunacy of ciremestances, which thrust the problem upon him at every turn and in every shape.

It has been brought against us as an accusation abroad, and repeated here by people who measure their 
country rather by what is thought of it than by what it is, that our war has not been distinctly and arowedly for the extinction of slavery, but a war rather for the preservation of our national power and greatness, in which the emancipation of the negro has been forced upon us by circumstances and accepted as a necessity. We are very far from denying this ; nay, we admit that it is so far true that we were slow to renounce our constitutional obligations even toward those who had absolved us by their own act from the letter of our duty. We are speaking of the government which, legally installed for the whole country, was bound, so long as it was possible, not to overstep the limits of orderly prescription, and could not, without abnegating its own very nature, take the lead in making rebellion an excuse for revolution. There were, no doubt, many ardent and sincere persons who seemed to think this as simple a thing to do as to lead off a Virginia reel. They forgot what should be forgotten least of all in a system like ours, that the administration for the time being represents not only the majority which elects it, but the minority as well, - a minority in this case powerful, and so little ready for emancipation that it was opposed even to war. Mr. Lincoln had not been chosen as general agent of an antislavery society, but President of the United States, to perform certain functions exactly defined by law. Whatever were his wishes, it was no less duty than policy to mark out for himself a line of action that would not further distract the country, by raising before their time questions which plainly would soon enough compel attention, and for which every day was making the answer more easy.

Meanwhile he must solve the riddle of this new Sphinx, or be devoured. Though Mr. Lincoln's policy in this critical affair has not been such is to satisfy 
those who demand an heroic treatment for even the most trifling occasion, and who will not cut their coat according to their cloth, unless they can borrow the scissors of Atropos, it has been at least not unworthy of the long-headed king of Ithaca. Mr. Lincoln had the choice of Bassanio offered him. Which of the three caskets held the prize that was to redeem the fortunes of the country? There was the golden one whose showy speciousness might have tempted a vain man ; the silver of compromise, which might have decided the choice of a merely acute one; and the leaden, - dull and homelylooking, as prudence always is, - yet with something about it sure to attract the eye of practical wisdom. Mr. Lincoln dallied with his decision perhaps longer than seemed needful to those on whom its awful responsibility was not to rest, but when he made it, it was worthy of his cautious but sure-footed understanding. The moral of the Sphinx-riddle, and it is a deep one, lies in the childish simplicity of the solution. Those who fail in guessing it, fail because they are over-ingenious, and cast about for an answer that shall suit their own notion of the gravity of the occasion and of their own dignity, rather than the occasion itself.

In a matter which must be finally settled by public opinion, and in regard to which the ferment of prejudice and passion on both sides has not yet subsided to that equilibrium of compromise from which alone a sound public opinion can result, it is proper enough for the private citizen to press his own convictions with all possible force of argument and persuasion; but the popular magistrate, whose judgment must become action, and whose action involves the whole country, is bound to wait till the sentiment of the people is so far advanced toward his own point of view, that what he does shall find support in it, instead of merely confusing it with 
new elements of division. It was not unnatural that men earnestly deroted to the saving of their country, and profoundly convinced that slavery was its only real enemy, should demand a decided policy round which all patriots might rally, - and this might have been the wisest course for an absolute ruler. But in the then unsettled state of the public mind, with a large party decrying even resistance to the slaveholders' rebellion as not only unwise, but even unlawful; with a majority, perhaps, even of the would-be loyal so long accustomed to regard the Constitution as a deed of gift conveying to the South their own judgment as to policy and instinct as to right, that they were in doubt at first whether their loyalty were due to the country or to slavery ; and with a respectable body of honest and influential men who still believed in the possibility of conciliation, - Mr. Lincoln judged wisely, that, in laying down a policy in deference to one party, he should be giving to the other the very fulcrum for which their disloyalty had been waiting.

It behooved a clcar-headed man in his position not to yield so firr to an honest indignation against the brokers of treason in the North as to lose sight of the materials for misleading which were their stock in trade, and to forget that it is not the falschood of sophistry which is to be feared, but the grain of truth mingled with it to make it specious, - that it is not the knavery of the leaders so much as the honesty of the followers they may seduce, that gives them power for evil. It was especially his duty to do nothing which might help the people to forget the true cause of the war in fruitless disputes about its inevitable consequences.

The doctrine of State rights can be so handled by an adroit demagogue as easily to confound the distinction between liberty and lawlessness in the minds of ignorant 
persons, accustomed always to be influenced by the sound of certain words, rather thin to reflect upon the principles which give them meining. For, though Secession involves the manifest absurdity of denying to a State the right of making war against any foreign power while permitting it against the United States; though it supposes a compact of mutual concessions and guaranties among States without any arbiter in case of dissension; though it contradicts common-sense in assuming that the men who framed our government did not know what they meant when they substituted Union for Confederation; though it falsifies history, which shows that the main opposition to the adoption of the Constitution was based on the argument that it did not allow that independence in the several States which alone would justify them in seceding; - yet, as slavery was universally admitted to be a reserved right, an inference could be drawn from any direct attack upon it (though only in self-defence) to a natural right of resistance, logical enough to satisfy minds untrained to detect fallacy, as the majority of men always are, and now too much disturbed by the disorder of the times, to consider that the order of events had any legitimate bearing on the argument. Though Mr. Lincoln was too sagacious to give the Northern allies of the Rehels the occasion they desired and even strove to provoke, yet from the beginning of the war the most persistent efforts have been made to confuse the pullic mind as to its origin and motives, and to drag the people of the loyal States down from the national position they had instinctively taken to the old level of party squabbles and antipathies. The wholly unprovoked rebellion of an oligarchy proclaiming negro slavery the corner-stone of free institutions, and in the first flush of over-hasty confidence venturing to parade the logical sequence of their leading dogma, 
"that slavery is right in principle, and has nothing to do with difference of complexion," has been represented as a legitimate and gallant attempt to maintain the true principles of democracy. The rightful endeavor of an established govermment, the least onerous that ever existed, to defend itself against a treacherous attack on its very existence, has been cumningly made to seem the wicked effort of a fanatical clique to force its doctrines on an oppressed population.

Even so long ago as when Mr. Lincoln, not yet convinced of the danger and magnitude of the crisis, was endeavoring to persuade himself of Union majorities at the South, and to carry on a war that was half peace in the hope of a peace that would have been all war, while he was still enforcing the Fugitive Slave Law, under some theory that Secession, however it might absolve States from their obligations, could not escheat them of their claims under the Constitution, and that slaveholders in rehellion had alone among mortals the privilege of having their cake and eating it at the same time, - the enemies of free government were striving to persuade the people that the war was an Abolition crusade. To rebel without reason was proclaimed as one of the rights of man, while it was carefully kept out of sight that to suppress rebellion is the first duty of government. All the evils that have come upon the country have been attributed to the Abolitionists, though it is hard to see how any party can become permanently powerful except in one of two ways, - either by the greater truth of its principles, or the extravagance of the party opposed to it. To fancy the ship of state, riding safe at her constitutional moorings, suddenly engulfed by a huge kraken of Abolitionism, rising from unknown depths and grasping it with slimy tentacles, is to look at the natural history of the matter with the 
eyes of Pontoppidan. To believe that the leaders in the Sonthern treason feared any danger from Abolitionism, would be to deny them ordinary intelligence, though there can be little doubt that they made use of it to stir the passions and excite the fears of their deluded accomplices. They rebelled, not because they thought slavery weak, but because they believed it strong enough, not to overthrow the government, but to get possession of it ; for it becomes daily clearer that they used rebellion only as a means of revolution, and if they got revolution, though not in the shape they looked for, is the American people to save them from its consequences at the cost of its own existence? The election of Mr. Lincoln, which it was clcarly in their power to prevent had they wished, was the occision merely, and not the cause, of their revolt. Abolitionism, till within a year or two, was the despised heresy of a few earnest persons, without political weight enough to carry the election of a parish constable ; and their cardinal principle was disunion, because they were convinced that within the Union the position of slavery was impregnable. In spite of the proverb, great effects do not follow from small causes, - that is, disproportionately small, - but from adequate causes acting under certain required conditions. To contrast the size of the oak with that of the parent acorn, as if the poor seed had paid all costs from its slender strong-box, may serve for a child's wonder; but the real miracle lies in that divine leagne which bound all the forces of nature to the service of the tiny germ in fulfilling its destiny. Everything has been at work for the past ten years in the cause of antislavery, but Garrison and Phillips have been far less successful propagandists than the slaveholders themselves, with the constantly-growing arrogance of their pretensions and encroachments. They have forced 
the question upon the attention of every voter in the Free States, by defiantly putting freedom and democracy on the defensive. But, even after the Kansas outrages, there was no wide-spread desire on the part of the North to commit aggressions, though there was a growing determination to resist them. The popular unanimity in favor of the war three years ago was but in small measure the result of antislavery sentiment, far less of any zeal for abolition. But every month of the war, every movement of the allies of slavery in the Free States, has been making Abolitionists by the thousand. The masses of any people, however intelligent, are very little moved by abstract principles of humanity and justice, until those principles are interpreted for them by the stinging commentary of some infringement upon their own rights, and then their instincts and passions, once aroused, do indeed derive an incalculable reinforcement of impulse and intensity from those higher ideas, those sublime traditions, which have no motive political force till they are allied with a sense of immediate personal wrong or imminent peril. Then at last the stars in their courses begin to fight against Sisera. Had any one doubted before that the rights of human nature are unitary, that oppression is of one hue the world over, no matter what the color of the oppressed, - had any one failed to see what the real essence of the contest was, - the efforts of the advocates of slavery among ourselves to throw discredit upon the fundamental axioms of the Declaration of Independence and the radical doctrines of Christianity, could not fail to sharpen his eyes.

While every day was bringing the people nearer to the conclusion which all thinking men saw to be inevitable from the beginning, it was wise in Mr. Lincoln to leave the shaping of his policy to events. In this country, 
where the rough and ready understanding of the people is sure at last to be the controlling power, a profound common-sense is the best genius for statesmanship. Hitherto the wisdom of the President's measures has been justified by the fact that they have always resulted in more firmly uniting public opinion. One of the things particularly admirable in the public utterances of President Lincoln is a certain tone of fumiliar dignity, which, while it is perhaps the most diffieult attaimment of mere style, is also no doubtful indication of personal character. There must be something essentially noble in an elective ruler who can descend to the level of confidential ease without losing respect, something very manly in one who can break through the etiquette of his conventional rank and trust himself to the reason and intelligence of those who hare elected him. No higher compliment was ever paid to a nation than the simple confidence, the fireside plaimness, with which Mr. Lincoln always addresses himself to the reason of the American people. This was, indeed, a true democrat, who grounded himself on the assumption that a democracy can think. "Come, let us reason together about this matter," has been the tone of all his addresses to the people; and accordingly we have nerer had a chief magistrate who so won to himself the love and at the same time the judgment of his countrymen. To us, that simple confidence of his in the right-mindedness of his fellow-men is very touching, and its success is as strong an argument as we have ever seen in favor of the theory that men can govern themselres. He never appeals to any vulgar sentiment, he never alludes to the humbleness of his origin; it probably never occurred to him, indeed, that there was anything higher to start from than manhood; and he put hinnself on a level with those he addressed, not by going down to them, but 
only by taking it for granted that they had brains and would come up to a common ground of reason. In an article lately printed in "The Nation," Mr. Bayard Taylor mentions the striking fact, that in the foulest dens of the Five Points he found the portrait of Lincoln. The wretched population that makes its hive there threw all its votes and more against him, and yet paid this instinctive tribute to the swcet humanity of his nature. Their ignorance sold its vote and took its money, but all that was left of manhood in them recognized its saint and martyr.

Mr. Lincoln is not in the habit of saying, "This is my opinion, or my theory," but, "This is the conclusion to which, in my judgment, the time has come, and to which, accordingly, the sooner we come the better for us." His policy has been the policy of public opinion based on adequate discussion and on a timely recognition of the influence of passing events in shaping the features of events to come.

One secret of Mr. Lincoln's remarkable success in captivating the popular mind is undoubtedly an unconsciousness of self which enables him, though under the necessity of constantly using the capital $I$, to do it without any suggestion of egotism. There is no single vowel which men's mouths can pronounce with such difference of effect. That which one shall hide away, as it were, behind the substance of his discourse, or, if he bring it to the front, shall use merely to give an agrecable accent of individuality to what he says, another shall make an offensive challenge to the self-satisfaction of all his hearers, and an unwarranted intrusion upon each man's sense of personal importance, irritating every pore of his ranity, like a dry northeast wind, to a gooseflesh of opposition and hostility. Mr. Lincoln has never studied Quinctilian; but he has, in the earnest sim. 
plicity and unaffected Americanism of his own character, one art of oratory worth all the rest. He forgets himself so entirely in his object as to give his $I$ the sympathetic and persuasire effect of $W e$ with the great body of his countrymen. Homely, dispassionate, showing all the rough-edged process of his thonght as it goes along; yet arriving at his conclusions with an honest kind of every-day logic, he is so eminently our representative man, that, when he speaks, it seems as if the people were listening to their own thinking aloud. The dignity of his thought owes nothing to any ceremonial garb of words, but to the manly morement that comes of settled purpose and an energy of reason that knows not what rhetoric means. There has been nothing of Cleon, still less of Strepsiades striving to underbid him in demagogism, to be found in the public utterances of Mr. Lincoln. He has always addressed the intelligence of men, nerer their prejudice, their passion, or their ignorance.

On the day of his death, this simple Western attorney, who according to one party was a vulgar joker, and whom the doctrinaires among his own supporters accused of wanting every element of statesmanship, was the most absolute ruler in Christendom, and this solely by the hold his good-humored sagacity had laid on the hearts and understandings of his countrymen. Nor was this all, for it appeared that he had rlrawn the great majority, not only of his fellow-citizens, but of mankind also, to his side. So strong and so persuasive is honest manliness without a single quality of romance or umeal sentiment to help it! A civilian during times of the most captivating military achievement, awkward, with no skill in the lower technicalities 
of manners, he left behind him a fame bcyond that of any conqueror, the memory of a grace higher than that of outward person, and of a gentlemanliness decper than mere breeding. Never before that startled April morning did such multitudes of men shed tears for the death of one they had never seen, as if with him a friendly presence had been taken away from their lives, leaving them colder and darker. Never was funeral panegyric so eloquent as the silent look of sympathy which strangers exchanged when they met on that day. Their common manhood had lost a kinsman. 


\section{THE LIFE AND LETTERS OF JAMES GATES PERCIVAL.}

7 HIS is an interesting and in many respects instrucfitting, in a loving spirit; and if he over-estimates both what Percival was and what he did, he cnables us to form our own judgment by letting him so far as possible speak for himself. The hook gives a rather curious picture of what the life of a man of letters is likely to be in a country not yet ripe for literary production, especially if he be not endowed with the higher qualities which command and can wait for that best of all successes which comes slowly. In a generation where everybody can write verses, and where certain modes of thought and turns of phrase have become so tyrannous that it is as hard to distinguish between the productions of one minor poet and another as among those of so many Minnesinger's or Troubadours, there is a demand for only two things, - for what chimes with the moment's whim of popular sentiment and is forgotten when that has changed, or for what is never an anachronism, because it slakes or seems to slake the eternal thirst of our nature for those ideal waters that glimmer before us and still before us in ever-renewing mirage. Percival met neither of these eonditions. With a nature singularly unplastic, unsympathetic, and self-involved, he was incapable of receiving into his own mind the ordinary emotions of men and giving them back in music; and 
with a lofty conception of the object and purposes of poesy, he had neither the resolution nor the power which might hare enabled him to realize it. He offers as striking an example as could be found of the poetic temperament unballasted with those less obvious qualities which make the poetic faculty. His verse carries every inch of canvas that diction and sentiment can crowd, but the craft is cranky, and we miss that deepgrasping keel of reason which alone can steady and give direction. His mind drifts, too waterlogged to answer the helm, and in his longer poems, like "Prometheus," half the voyage is spent in trying to make up for a leeway which becomes at last irretrievable. If he had a port in view when he set out, he seems soon to give up all hope of ever reaching it; and wherever we open the log-book, we find him rumning for nowhere in particular, as the wind happens to lead, or lying-to in the merest gale of verbiage. The truth is, that Percival was led to the writing of verse by a sentimental desire of the mind, and not by that concurring instinct of all the faculties which is a self-forgetting passion of the entire man. Too excituble to possess his subject fully, as a man of mere talent may often do, he is not possessed by it as the man of genius is, and seems helplessly striving; the greater part of the time, to make out what, in the name of common or uncommon sense, he is after. With all the stock properties of verse whirling and dancing about his ears puffed out to an empty show of life, the reader of much of his blank verse feels as if a mob of welldraperied clothes-lines were rioting about him in all the unwilling ecstasy of a thunder-gust.

Percival, living from 1795 to 1856 , arrived at manhood just as the last war with England had come to an end. Poor, shy, and proud, there is nothing in his earlier years that might not be paralleled in those of 


\section{LIFE AND LETTERS OF JAMES GATES PERCIVAL.}

hundreds of sensitive boys who gradually get the nonsense shaken out of them in the rough school of life. The length of the schooling needful in his case is what makes it peculiar. Not till after he was fifty, if even then, did he learn that the world never takes a man at his own valuation, and never pays money for what it does not want, or think it wants. It did not want his poetry, simply because it was not, is not, and by no conceivable power of argument can be made, interesting, the first duty of every artistic product. Percival, who would have thought his neighbors mad if they had insisted on his buying twenty thousand refrigerators merely because they had been at the trouble of making them, and found it convenient to turn them into cash, could never forgive the world for taking this business view of the matter in his own case. He went on doggedly, making refrigerators of every possible pattern, and comforted himself with the thought of a wiser posterity, which should have learned that the purpose of poetry is to cool and not to kindle. His "Mind," which is on the whole perhaps the best of his writings, vies in coldness with the writings of his brother doctor, Akenside, whose "Pleasures of Imagination" are something quite other than pleasing in reality. If there be here and there a semblance of pale fire, it is but the reflection of moonshine upon ice. Akenside is respectable, because he really had something new to say, in spite of his pompous, mouthing way of saying it; but when Percival says it orer again, it is a little too much. In his more ambitious pieces, - and it is curious how literally the word "pieces" applies to all he did, — he devotes himself mainly to telling us what poetry ought to be, as if mankind were not always more than satisfied with any one who fulfils the true office of poet, by showing them, with the least possiblo fuss, what it is. Percival was a 
professor of poetry rather than a poet, and we are not surprised at the number of lectures he reads us, when we learn that in early life he was an excellent demonstrator of anitomy, whose subject must be dead before his business with it begins. His interest in poetry was always more or less scientific. He was forever trying experiments in matter and form, especially the latter. And these were especially unhappy, because it is plain that he had no musical ear, or at best a very imperfect one. His attempts at classical metres are simply unreadable, whether as verse or prose. He contrives to make even the Sapphic so, which when we read it in Latin moves fuatly to our modern accentuation. Let any one who wishes to feel the difference between ear and $n o$ ear compare Percival's specimens with those in the simme kind of Coleridge, who had the finest metrical sense since Milton. We take this very experimenting to be a sufficient proof that Percival's faculty, such as it was, and we do not rate it highly, was artificial, and not innate. The true poet is much rather experimented upon by life and nature, by joy and sorrow, by beauty and defect, till it be found out whether he have any hidden music in him that can sing them into an accord with the eternal harmony which we call God.

It is easy to trace the literary influences to which the mind of Percival was in turn subjected. Early in life we find a taint of Byronism, which indeed does not wholly disappear to the last. There is among his poems "An Imprecation," of which a single stanza will suffice as a specimen :

"Wrapped in sheets of gory lightning, While cursed night-hags ring thy knell, May the arm of vengeance bright'ning, O'er thee wave the sword of hell!"

If we could fancy Laura Matilda shut up tipsy in the 


\section{LIFE AND LETTERS OF JAJIFS GATES PERCIVAL.}

watch-house, we might suppose her capable of this melodious substitute for swearing. We confess that we cannot read it without laughing, after learning from Mrr. Ward that its Salmoneus-thunderbolts were launched at the comfortable little city of Hartford, because the poet fancied that the inhabitants thereof did not like him or his verses so much as he himself did. There is something deliciously ludicrous in the conception of nighthags ringing the orthodox bell of the Second Congregational or First Baptist Meeting-house to summon the parishioners to witness these fatal consequences of not reading Percival's poems. Nothing less than the foar of some such catastrophe could compel the perusal of the greater part of them. Next to Byron comes Mloore, whose cloying suntimentalism and too facile melody are recalled by the sulject and treatment of very many of the shorter lyrics of Percival. In "Prometheus" it is Shelley who is paramount for the time, and Shelley at his worst period, before hị unwieldy abundance of incoherent words and imiges, that were merely words and images without any meaning of real experience to gire them solidity, had heen compressed in the stricter moulds of thought and study. In the blank verse again, we encounter Wordsworth's tone and sentiment. These were no good models for Percival, who always improvised, and who seems to have thought rerse the great distinction between poetry and prose. Percival got nothing from Shelley but the fatal copiousness which is his vice, nothing from Wordsworth but that tendency to preach at every comer about a sympathy with nature which is not his real distinction, and which becomes a wearisome cant at second-hand. Shelley and Wordsworth are both stilted, though in different ways. Shelley wreathed his stilts with flowers; while Wordsworth, protesting against the use of them as sinful, mounts his 
solemnly at last, and stalks away conscientiously eschewing whatever would serve to hide the naked wood, nay, was it not Gray's only that were scandalous, and were not his own, modelled upon those of the sainted Cowper, of strictly orthorlox pattern after all ? Percival, like all imitators, is canght by the defects of what he copies, and exaggerates them. With him the stilts are the chief matter; and getting a taller pair than either of his predecessors, he lifts his commonplace upon them only to make it more drearily conspicuous. Shelley has his gleams of unearthly wildfire, Wordsworth is by fits the most deeply inspired man of his generation; but Percival has no lucid interval. He is pertinaciously and umappeasably dull, _ as dull as a comedy of Goethe. $\mathrm{He}$ never in his life wrote a rememberable verse. We should not have thought this of any consequence now, for we need not try to read him, did not $\mathrm{Mr}$. Ward with amusing gravity all along assume that he was a great poet. There was scarce timber enough in him for the making of a Tiedge or a Hagedorn, both of whom he somewhat resembles.

Percival came to maturity at an unfortunate time for a man so liable to self-delusion. Leaving college with so imperfect a classical training (in spite of the numerous "testimonials" cited by Mr. Ward) that he was capable of laying the accent on the second syllable of Pericles, he seems never to have systematically trained even such faculty as was in him, but to have gone on to the end mistaking excitability of brain for wholesome exercise of thought. The consequence is a prolonged immaturity, which makes his latest volume, published in 1813, as crude and as plainly wanting in enduring quality as the first number of his "Clio." We have the same old complaints of neglected genius, - as if genius could ever be neglected so long as it has the peremnial consolation of 


\section{$1 S 4$ LIFE AND LETTERS OF JAMES GATES PERCIVAL.}

its own divine society, - the same wilted sentiment, the same feeling about for topics of rerse in which he may possibly find that inspiration from without which the true poet cannot flee from in himself. These tedious wailings about heavenly powers suffocating in the heavy atmosphere of an uncongenial, unrecognizing world, and Pereival is profuse of them, are simply an advertisement to whoever has ears of some innate disability in the man who utters them. Heavenly powers know very well how to take care of themselves. The poor "World," meaning thereby that small fraction of society which has any personal knowledge of an author or his affiirs, has had great wrong done it in such matters. It is not, and never was, the powers of a man that it neglects, - it could not if it would, - but his weaknesses, and especially the publication of them, of which it grows weary. It can never supply any man with what is wanting in himself, and the attempt to do it only makes bad worse. If a man can find the proof of his own genius only in public appreciation, still worse, if his vanity console itself with taking it as an eridence of rare qualities in himself that his fellow-mortals are unable to see them, it is all up with him. The "World" resolutely refused to find Wordsworth entertaining, and it refuses still, on good grounds; but the genius that was in him bore up unflinchingly, would take no denial, got its claim admitted on all hands, and impregnated at last the literature of an entire generation, though habitans in sicco, if ever genius did. But Percival seems to have satisfied himself with a syllogism something like this: Men of genius are neglected; the more neglect, the more genius; I am altogether neglected, - ergu, wholly made up of that priceless material.

The truth was that he suffered rather from overappreciation ; and "when," says a nameless old French. 
man, "I see a man go up like a rocket, I expect before long to see the stick come down." The times were singularly propitious to mediocrity. As in Holland one had only to

\section{"Invent a shovel and be a magistrate,"}

so here to write a hundred blank verses was to be immortal, till somebody else wrote a hundred and fifty blanker ones. It had been resolved unanimously that we must and would have a national literature. England, France, Spain, Italy, each already had one, Germany was getting one made as fast as possible, and Ireland vowed that she once had one far surpassing them all. To be respectable, we must have one also, and that speedily. That we were not yet, in any true sense, a nation; that we wanted that literary and social atmosphere which is the breath of life to all artistic production; that our scholarship, such as it was, was mostly of that theological sort which acts like a prolonged drouth upon the brain; that our poetic fathers were Jocl Barlow and Timothy Dwight, - was nothing to the purpose; a literature adapted to the size of the country was what we must and would have. Given the number of square miles, the length of the rivers, the size of the lakes, and you have the greatness of the literature we were bound to produce without further delay. If that little dribble of an Avon had succeeded in engendering Shakespeare, what a giant might we not look for from the mighty womb of Mississippi! Physical Geography for the first time took her rightful place as the tenth and most inspiring Muse. A glance at the map would satisfy the most incredulous that she had done her best for us, and should we be wanting to the glorious opportunity? Not we indecd! So surely as Franklin invented the art of printing, and Fulton the steam-engine, we would invent us a great poet in time 
to send the news by the next packet to England, and teach her that we were her masters in arts as well as arms.

Percival was only too ready to be invented, and he forthwith produced his bale of verses from a loom capable of turning off a hitherto unheard-of number of yards to the hour, and perfectly adapted to the amplitude of our territory, inasmuch as it was manufactured on the theory of corering the largest surfice with the least possible amount of meaning that would hold words together. He was as ready to accept the perilous emprise, and as loud in asserting his claim thereto, as Sir Kiay used to be, and with much the same result. Our critical journals - and America certainly has led the world in a department of letters which of course requires no outfit but the power to read and write, gratuitously furnished by our public schools - received him with a shout of welcome. Here came the true deliverer at list, mounted on a steed to which he himself had given the new name of "Pegĩsus," - for we were to be original in everything, - and certainly blowing his own trumpet with remarkable vigor of lungs. Solitary enthusiasts, who had long awaited this sublime avatar, addressed him in somnets which he accepted with a gravity beyond all praise. (To be sure, even Mr. Ward seems to allow that his sense of humor was hardly equal to his other transecndent endowments.) His path was strewn with laurel - of the native variety, altogether superior to that of the Old World, at any rate not precisely like it. Verses signed "P.," as like each other as two peas, and as much like poetry as that vegetable is like a peach, were watched for in the corner of a newspaper as an astronomer watches for a new planet. There was never anything so comically umreal since the crowning in the Capitol of Messer Francesco Petrarca, Grand 
Sentimentalist in Ordinary at the Court of King Robert of Naples. Unhappily, Percival took it all quite seriously. There was no praise too ample for the easy clasticity of his swallow. He believed himself as gigantic as the shadow he cast on these rolling mists of insubstantial adulation, and life-long he could nerer make out why his fine words refused to butter his parsnips for him, nay, to furnish both parsnips and sauce. While the critics were debating precisely how many of the prime qualities of the great pocts of his own and preceding generations he combined in his single genius, and in what particular respects he surpassed them all, - a point about which he himself secms never to have had any doubts, - the public, which could read Scott and Byron with aridity, and which was beginning even to taste Wordsworth, found his verses inexpressibly wearisome. They would not throng and subscribe for a collected edition of those works which singly had been too much for them. With whatever dulness of sense they may be charged, they have a remarkably keen scent for tediousness, and will have none of it unless in a tract or scrmon, where, of course, it is to be expected. Perciral never forgare the public; but it was the crities that he never should have forgiren, for of all the maggots that can make their way into the brains through the ears, there is none so disastrous as the persuasion that you are a great poet. There is surely something in the construction of the ears of small authors which lays them specially open to the inroads of this pest. It tickles pleasantly while it eats away the fibre of will, and incapacitates a man for all honest commerce with realities. Unhappily its insidions titillation seems to have been Percival's one great pleasure during life.

We began by saying that the book before us was interesting and instructive; but we meant that it was so 


\section{LIFE AND LETTERS OF JAMES GATES PERCIVAL.}

not so much from any positive merits of its own as by the lesson which almost every page of it suggests. To those who hare some knowledge of the history of literature, or some experience in life, it is from beginning to end a history of weakness mistaking great desires for great powers. If poetry, in Bacon's noble definition of it, "adapt the shows of things to the desires of the mind," sentimentalism is equally skilful in making realitics shape themselves to the cravings of ranity. The theory that the poet is a being above the world and apart from it is true of him as an observer only who applies to the phenomena about him the test of a finer and more spiritual sense. That he is a creature divincly set apart from his fellow-men by a mental organization that makes them mutually unintelligible to each other, is in flat contradiction with the lives of those poets universally acknowledged as greatest. Dante, Shakespeare, Cervantes, Calderon, Milton, Molière, Goethe, - in what conceivable sense is it true of them that they wanted the manly qualities which made them equal to the demands of the world in which they lived? That a poet should assume, as Victor Hugo used to do, that he is a reorganizer of the moral world, and that works cumningly adapted to the popular whim of the time form part of some mysterious system which is to give us a new heaven and a new earth, and to remodel laws of art which are as unchangeable as those of astronomy, can do no very great harm to any one but the author himself, who will thereby be led astray from his proper function, and from the only path to legitimate and lasting success. But when the theory is carried a step further, and we are asked to believe, as in Percival's case, that, because a man can write verses, he is excmpt from that inerorable logic of life and eircumstance to which all other men are subjected, and to which it is wholesome for them 
that they should be, then it becomes mischievous, and calls for a protest from all those who have at heart the interests of good morals and healthy literature. It is the theory of idlers and dilettanti, of fribbles in morals and declaimers in verse, which a young man of real power may dally with during some fit of mental indigestion, but which when accepted by a mature man, and carried along with him through life, is a sure mark of feebleness and of insincere dealing with himself. Percival is a good example of a class of authors unhappily too numerous in these latter days. In Europe the natural growth of a world ill at ease with itself and still nervous with the frightful palpitation of the French Revolution, they are but feeble exotics in our healthier air. Without faith or hope, and deprived of that outward support in the habitual procession of events and in the authoritative limitations of thought which in ordinary times gives steadiness to feeble and timid intellects, they are turned inward, and forced, like Hudibras's sword,

"To eat into themselves, for lack

Of other thing to hew and hack."

Compelled to find within them that stay which had hitherto been supplied by creeds and institutions, they learned to attribute to their own consciousness the grandeur which belongs of right only to the mind of the human race, slowly endeavoring after an equilibrium between its desires and the external conditions under which they are attainable. Hence that exaggeration of the individual, and depreciation of the social man, which has become the cant of modern literature. Abundance of such phenomena accompanied the rise of what was called Romanticism in Germany and France, reacting to some extent even upon England, and consequently America. The smaller poets erected themselves into a kind of guild, 


\section{LIFE AND LETTERS OF JAMES GATES PERCIVAL.}

into which all were admitted who gave proof of a certain feebleness of character which rendered them superior to their grosser fellow-men. It was a society of cripples undertaking to teach the new generation how to walk. Meanwhile, the object of their generous solicitude, what with clinging to Mother Past's skirts, and helping itself by every piece of household furniture it could lay hands on, learned, after many a tumble, to get on its legs, and to use them as other generations had done before it. Percival belonged to this new order of bards, weak in the knees, and thinking it healthy exercise to climb the peaks of Dreamland. To the rague and misty views attainable from those sublime summits into his own vast interior, his reports in blank verse and otherwise did ample justice, but failed to excite the appetite of mankind. He spent his life, like others of his cliss, in proclaiming himself a neglected Columbus, ever ready to start on his royage when the pullic would surpply the means of building his ships. Neanwhile, to be ready at a moment's warning, he packs his mind pellmoll like a carpet-bag, wraps a geologist's hammer in a shirt with a Byron collar, does up Volney's "Rluins" with an old volume of Wordsworth, and another of Bell's "Anatomy" in a loose sheet of Webster's Dictionary, jams MLore's poems between the leares of Bopp's Grammer, - and forgets only such small matters as comlss and brushos. It never seems to have entered his head that the gulf between genius and its new world is never too wide for a stout swimmer. Like all sentimentalists, he reversed the process of nature, which makes it a part of greatness that it is a simple thing to itself, howerer much of a marvel it may be to other men. Ho discovered his own genius, as he supposed, - a thing impossible had the genius been real. Domne never wrote a profounder verse than

"Who knows his virtue's name and place, hath none." 
Percival's life was by no means a remarkable one, except, perhaps, in the number of chances that secm to have been offered him to make something of himself, if anything were possibly to be made. He was never without friends, never without opportunities, if he could have availed himself of them. It is pleasant to see Mr. Ticknor treating him with that considerate kindness which many a young scholar can remember as shown so generously to himself. But nothing could help Percival, whose nature had defeat worked into its very composition. He was not a real, but an imaginary man. His early attempt at suicide (as Mr. Ward seems to think it) is typical of him. He is not the first young man who, when crossed in love, has spoken of "loupin o'er a linn," nor will he be the last. But that any one who really meant to kill himself should put himself resolutely in the way of being prevented, as Percival did, is hard to believe. Châteaubriand, the arch sentimentalist of these latter days, had the same harmless velleity of self-destruction, - enough to scare his sister and so give him a smack of sensation, - but a very different thing from the settled will which would be really perilous. Shakespeare, always true to Nature, makes Hamlet dally with the same exciting fancy. Alas! self is the one thing the sentimentalist never truly wishes to destroy! One remarkable gift Percival seems to have had, which may be called memory of the eye. What he saw he never forgot, and this fitted him for a good geological observer. How great his power of combination was, which alone could have made him a great geologist, we cannot determine. But he seems to have shown but little in other directions. His faculty of acquiring foreign tongues we do not value so highly as Mr. Ward. We have known many otherwise inferior men who possessed it. Indeed, the power to express the same nothing in ten different languages is 


\section{LIFE AND LETTERS OF JAMES GATES PERCIVAL.}

something to be dreaded rather than admired. It gives a horrible advantage to dulness. The best thing to be learned from Percival's life is that he was happy for the first time when taken away from his vague pursuit of the ideal, and set to practical work. 


\section{THOREAU.}

WHAT contemporary, if he was in the fighting period of his life, (since Nature sets limits about her conscription for spiritual fields, as the state does in physical warfare,) will ever forget what was somewhat vaguely called the "Transcendental Movement" of thirty years ago? Apparently set astirring by Carlyle's essays on the "Signs of the Times," and on "History," the final and more immediate impulse seemed to be given by "Sartor Resartus." At least the republication in Boston of that wonderful Abraham à Sancta Clara sermon on Lear's text of the miserable forked radish gave the signal for a sudden mental and moral mutiny. Ecce nune tempus acceptabile! was shouted on all hands with every variety of emphasis, and by voices of every conceivable pitch, representing the three sexes of men, women, and Lady Mary Wortley Montagues. The nameless eagle of the tree Ygdrasil was about to sit at last, and wild-eyed enthusiasts rushed from all sides, each eager to thrust under the mystic bird that chalk egg from which the new and fairer Creation was to be hatched in due time. Redeunt Saturnia regna, - so far was certain, though in what shape, or by what methods, was still a matter of debate. Every possible form of intellectual and physical dyspepsia brought forth its gospel. Bran had its prophets, and the presartorial simplicity of Adam its martyrs, tailored impromptu from the tar-pot by incensed 
neighbors, and sent forth to illustrate the "feathired Mercury," as defined by Webster and Worcester. Plai ${ }^{\text {n- }}$ ness of speech was carried to a pitch that would have taken away the breath of George Fox ; and even swearing had its evangelists, who answered a simple inquiry after their health with an elaborate ingenuity of imprecation that might have been honorably mentioned by Marlborough in general orders. Everybody had a mission (with a capital M) to attend to everybody-else's business. No brain but had its private maggot, which must have found pitiably short commons sometimes. Not a few impecunious zealots abjured the use of money (unless carned by other people), professing to live on the internal revenues of the spirit. Some had an assurance of instant millennium so soon as hooks and eyes should be substituted for buttons. Communities were established where everything was to be common but common-sense. Men renounced their old gods, and hesitated only whether to bestow their furloughed allegiance on Thor or Budh. Conventions were held for erery hitherto inconceivable purpose. The belated gift of tongues, as among the Fifth Monarchy men, spread like a contagion, rendering its victims incomprehensible to all Christian men; whether equally so to the most distant possible heathen or not was unexperimented, though many would have subseribed liberally that a fair trial might be made. It was the pentecost of Shinar. The day of utterances reproduced the day of rebuses and anagrams, and there was nothing so simple that uncial letters and the style of Diphilus the Labyrinth could not turn into a riddle. Many foreign revolutionists out of work added to the general misunderstanding their contribution of broken English in every most ingenious form of fracture. All stood ready at a moment's notice to reform everything but themselves. The general motto was :- 


\section{"And we'll talk with them, too, And take upon's the mystery of things As if we were God's spies."}

Nature is always kind enough to give even her clouds humorous lining. We have barely hinted at the comic ise of the affair, for the material was endless. This was a . whistle and trailing fuse of the shell, but there was sid ery solid and serious kernel, full of the most deadly the-losiveness. Thoughtful men divined it, but the gena vality suspected nothing. The word "transcendental" "then was the maid of all work for those who conld not think, as "Pre-Raphaelite" has been more recently for people of the same limited housekeeping. The truth is, that there was a much nearer metaphysical relation and a much more distant xsthetic and literary relation between Carlyle and the Apostles of the Newness, as they were called in New England, than has commonly been supposed. Both represented the reaction and revolt against Philisterei, a renewal of the old battle begun in modern times by Erasmus and Reuchlin, and continued by Lessing, Goethe, and, in a far narrower sense, by Heine in Germany, and of which Fielding, Sterne, and Wordsworth in different ways have been the leaders in England. It was simply a struggle for fresh air, in which, if the windows could not be opened, there was danger that panes would be broken, though painted with images of saints and martyrs. Light colored by these reverend effigies was none the more respirable for being picturesque. There is only one thing better than tradition, and that is the original and eternal life out of which all tradition takes its rise. It was this life which the reformers domanded, with more or less clearness of consciousness and expression, life in politics, life in literature, life in religion. Of what use to import a gospel from Judæa, if we leave behind the soul that made it possible, the God 
who keeps it forever real and present? Surely . « 2na and Pharpar are better than Jordan, if a living fait. be mixed with those waters and none with these.

Scotch Presbyterianism as a motive of spiritual pr. ress was dead; New England Puritanism was in $1^{0}$ manner dead; in other words, Protestintism had mle its fortune and no longer protested; but till Ca le spoke out in the Old World and Emerson in the IW, no one had dared to proclaim, Le roi est mort: vive le . $?$. The meaning of which proclamation was essentially this : the vital spirit has long since departed out of this form once so kingly, and the great seal has been in commission long enough; but meanwhile the soul of man, from which all power emanates and to which it reverts, still survives in undiminished royalty; God still survives, little as you gentlemen of the Commission seem to be aware of it, - nay, may possibly outlive the whole of you, incredible as it may appear. The truth is, that both Seoteh Presbyterianism and New England Puritanism made their new avatar in Carlyle and Emerson, the heralds of their formal decease, and the tendency of the one toward Authority and of the other toward Independency might have been prophesied by whoever had studied history. The necessity was not so much in the men as in the principles they represented and the traditions which overruled them. The Puritanism of the past found its unwilling poet in Hawthorne, the rarest creative imagination of the contury, the rarest in some ideal respects since Shakespeare; but the Puritanism that camnot die, the Puritanism that made New England what it is, and is destined to make Ameriea what it should be, found its voice in Emerson. Though holding himself aloof from all active partnership in movements of reform, he has been the sleeping partner who has supplied a great part of their capital. 
The artistic range of Emerson is narrow, as every well-read critic must feel at once; and so is that of Eschylus, so is that of Dante, so is that of Montaigne, so is that of Schiller, so is thet of nearly every one except Shakespeare; lut there is a gange of height no less than of breadth, of individuality as well as of comprehensiveness, and, above all, there is the standard of genetic power, the test of the masculine as distinguished from the receptive minds. There are staminate plants in literature, that make no fine show of fruit, but without whose pollen, quintessence of fructifying gold, the garden had been barren. Emerson's mind is emphatically one of these, and there is no man to whom our resthetic culture owes so much. The Puritan revolt had made us ecclesiastically, and the Revolution politically independent, but we were still socially and intellectually moored to English thought, till Emerson cut the cable and gave us a chance at the dangers and the glories of blue water. No man young enough to have felt it can forget, or cease to be grateful for, the mental and moral mudge which he received from the writings of his highminded and brave-spirited countryman. That we agree with him, or that he always agrees with himself, is aside from the question; but that he arouses in us something that we are the better for haring awakened, whether that something be of opposition or assent, that he speaks always to what is highest and least selfish in us, few Americans of the generation younger than his own would be disposed to deny. His oration before the Phi Beta Kappa Society at Cambridge, some thirty years ago, was an event without any former parallel in our literary amnals, a scene to be always treasured in the memory for its picturesqueness and its inspiration. What crowded and breathless aisles, what windows clustering with eager heads, what enthusiasm of approval, 
what grim silence of foregone dissent! It was our Yankee version of a lecture by Abelard, our Harvard parallel to the last public appearances of Schelling.

We said that the Transcendental Movement was the protestant spirit of Puritanism secking a new outlet and an escape from forms and creeds which compressed rather than expressed it. In its motives, its preaching, and its results, it differed radically from the doctrine of Carlyle. The Scotchman, with all his genius, and his humor gigantesque as that of Rabelais, has grown shriller and shriller with years, degenerating sometimes into a common scold, and emptying very unsavory vials of wrath on the hear of the sturdy British Socrates of worldly common-sense. The teaching of Emerson tended much more exclusively to self-culture and the independent derelopment of the individual man. It seemed to many almost Pythagorcan in its roluntary seclusion from commonwealth afficirs. Both Carlyle and Emerson were disciples of Goethe, but Emerson in a far truer sense; and while the one, from his bias toward the eccentric, has degenerated more and more into mannerism, the other has clarified steadily toward perfection of style, exquisite fineness of material, unobtrusive lowness of tone and simplicity of fashiom, the most high-bred garb of expression. Whatever may be said of his thought, nothing can be finer than the delicious limpidness of his phrase. If it was ever questionable whether democracy could develop a gentleman, the problem has been affirmatively solved at last. Carlyle, in his cynicism and his admiration of force in and for itself, has become at last positively inhuman; Emerson, reverencing strength, secking the highest outeome of the individual, has found that society and polities are also main elements in the attiniment of the desired end, and has drawn steadily manward and worldward. The two men represent re- 
spectively those grand personifications in the drama of Aschylus, Bia and Kрátos.

Among the pistillate plants kindled to fruitage by the Emersonim pollen, Thorean is thus fur the most remarkable; and it is something eminently fitting that his posthumous works should be offered us by Emerson, for they are strawberries from his own garden. A singular mixture of varieties, indeed, there is; - alpine, some of them, with the flavor of rare mountain air; others wood, tasting of sunny roadside banks or shy openings in the forest; and not a few seedlings swollen hugely by culture, but lacking the fine natural aroma of the more modest kinds. Strange books these are of his, and interesting in many ways, - instructive chiefly as showing how considerable a crop may be raised on a compraratively narrow close of mind, and how much a man may make of his life if he will assiduously follow it, though perhaps never truly finding it at last.

We have just been renewing our recollection of Mr: Thorean's writings, and have read through his six volumes in the order of their production. We shall try to give an arlecuate report of their impression upon us both as critic and as mere reader. He seems to us to have been a man with so high a conceit of himself that he accepted without questioning, and insisted on our accepting, his defects and weaknesses of character as virtues and powers peculiar to himself. Was he indolent, he finds none of the activities which attract or employ the rest of mankind worthy of him. Was he wanting in the qualities that make success, it is success that is contemptible, and not himself that lacks persistency and purpose. Was he poor, money was an unmixed evil. Did his life seem a selfish one, he condemns doing good as one of the wakest of superstitions. To he of use was with him the most killing bait of the wily 
tempter Uselessness. He had no faculty of gencralization from outside of himself, or at least no experience which would supply the material of such, and he makes his own whim the law, his own range the horizon of the mirerse. Ife condemus a world, the hollowness of whose satisfictions he had never had the means of test. ing, and we recognize Apemantus behind the mask of 'T'imon. II had little active imagrimation; of the recep. tive he had much. His appreciation is of the highest quality; his critical power, from want of continuity of mind, very limited and inadequate. He somewhere cites a simile from Ossian, as an example of the superiority of the old poetry to the new, though, even were the historic evidence less convincing, the sentimental melancholy of those poems should be conclusive of their modermuess. He hat no artistic power such as controls a great work to the serene balance of completeness, but exquisite mechanical skill in the shaping of sentences and paragraphs, or (more rarely) short lits of verse for the expression of a detached thought, sentiment, or image. Itis works grive one the fecling of a sky full of stars, - something impressive and exhilarating certainly, something high overhead and freckled thickly with spots of isolated brightness; but whether these have any mutual relation with each other, or have any concern with our mundane matters, is for the most part matter of conjecture, - astrology as yet, and not astronomy.

It is curious, considering what Thoreau afterwards became, that he was not lyy nature an oloserver. He only saw the things he looked for, and was less poet than naturalist. Till he huilt his Walden shanty, he did not know that the hickory grew in Concord. Till he went to Maine, he had never seen phosphorescent wood, a phenomenon carly familiar to most country boys. At forty he speaks of the seeding of the pine as 
a new discovery, though one should have thought that its gold-dust of blowing pollen might have earlier drawn his eye. Neither his attention nor his genius was of the spontaneous kind. He discovered nothing. He thought everything a discovery of his own, from moonlight to the plinting of acorns and nuts by squirrels. This is a defect in lis character, but one of his chicf charms as a writer. Everything grow's fresh under his hand. IIe delved in his mind and nature; he planted them with all manner of native and foreign seeds, and reaped assiduously. Ho was not merely solitary, ho would be isolated, and succeeded at last in almost persuading himself that he was autochthonous. He valued everything in proportion as he fancied it to be exclusively his own. He complains in "Walden," that there is no one in Concord with whom he could talk of Oriental literature, though the man was living within two miles of his hut who had introduced him to it. This intellectual selfishness becomes sometimes almost painful in reading him. He lacked that generosity of "communication "which Johnson admired in Burke. De Quincey tells us that Wordsworth was impatient when any ono else spoke of mountains, as if he had a peculiar property in them. And we can readily understand why it should be so: no one is satisfied with another's appreciation of his mistress. But Thoreau seems to have prized a lofty way of thinking (often we should be inclined to call it a remote one) not so much because it was good in itself as because he wisherl few to share it with him. It seems now and then as if he did not seck to lure others up "alove our lower recion of turmoil," but to leave his own name cut on the mountain peak as the first climber. This itch of originality infects his thought and style. To be misty is not to be mystic. He turns commonplaces end for end, and fancies it makes something new 
of them. As we walk down Park Street, our eye is caught by Dr. Windship's dumb-bells, one of which bears an inscription testifying that it is the heaviest ever put up at arm's length by any athlete; and in reading Mr. Thoreau's broks we camnot help fecling as if he sometimes invited our attention to a particular sophism or paradox as the biggest yet maintained by any single writer. He seeks, at all risks, for perversity of thought, and revives the age of concetti while he funcies himself going back to a pre-classical nature. "A day," he says, "passed in the society of those Greek sages, such as described in the Banquet of Xenophon, would not be comparable with the dry wit of decayed cranberry-vines and the fresh $\Lambda$ ttic salt of the mossbeds." It is not so much the True that he lores as the Out-of-the-Way. As the Brazen Age shows itself in other men by exaggeration of phrase, so in him by extravagance of statement. He wishes always to trump your suit and to ruff when you least expect it. Do you lore Nature because she is beautiful? He will find a better argument in her ugliness. Are you tired of the artificial man? He instantly dresses you up an ideal in a Penobscot Indian, and attributes to this creature of his otherwise-mindedness as peculiarities things that are common to all woodsmen, white or red, and this simply because he has not studied the pale-faced variety.

This notion of an absolute originality, as if one could hare a patent-right in it, is an absurdity. A man cannot escape in thought, any more than he can in language, from the past and the present. As no one ever invents a word, and yet language somehow grows by general contribution and necessity, so it is with thought. Mr. Thoreau seems to us to insist in public on going back to flint and steel, when there is a match-box in his pocket which he knows very well how to use at a pinch. Origi- 
nality consists in power of digesting and assimilating thought, so that they become part of our life and substance. Montaigne, for example, is one of the most original of authors, though he helped himself to ideas in every direction. But they turn to blood and coloring in his style, and give a freshness of complexion that is forever charming. In Thoreau much seems yet to be foreign and unassimilated, showing itself in symptoms of indigestion. A preacher-up of Nature, we now and then detect under the surly and stoic garb something of the sophist and the sentimentalizer. We are far from implying that this was conscious on his part. But it is much easier for a man to impose on himself when he measures only with himself. A greater familiarity with ordinary men would have done Thoreau good, by showing him how many fine qualities are common to the race. The radical vice of his theory of life was, that he confounded physical with spiritual remoteness from men. One is far enough withdrawn from his fellows if he keep himself clear of their weaknesses. He is not so truly withdrawn as exiled, if he refuse to share in their strength. "Solitude," says Cowley, "can be well fitted and set right but upon a very few persons. They must have enough knowledge of the world to see the ranity of it, and cnough virtue to despise all vanity." It is a morbid self-consciousness that pronounces the world of men empty and worthless before trying it, the instinctive evasion of one who is sensible of some innate weakness, and retorts the accusation of it before any has made it but himself. To a healthy mind, the world is a constant challenge of opportunity. Mr. Thoreau had not a healthy mind, or he would not have been so fond of prescribing. His whole lifo was a search for the doctor. The old mrstics had a wiser sense of what the world was worth. They or- 
dained a severe apprenticeship to law, and even ceremo. nial, in order to the gaining of freedom and mastery over these. Seven years of service for Rachel were to be rewarded at last with Leah. Seven other years of faithfulness with her were to win them at last the true bride of their souls. Active Life was with them the only path to the Contemplative.

Thoreau had no humor, and this implies that he was a sorry logician. Himself an artist in rhetoric, he confounds thought with style when he undertakes to speak of the latter. He was forever talking of getting away from the world, but he must be always near enough to it, nay, to the Concord corner of it, to feel the impression he makes there. He verifies the shrewd remark of Sainte-Benve, "On touche encore à son temps et trèsfort, même quand on le repousse." This egotism of his is a Stylites pillar after all, a seclusion which keeps him in the public eye. The dignity of man is an excellent thing, but therefore to hold one's self too sacred and precious is the reverse of excellent. There is something delightfully absurd in six volumes addressed to a world of such "vulgar fellows" as Thoreau affirmed his fellowmen to be. We once had a glimpse of a genuine solitary who spent his winters one hundred and fifty miles beyond all human communication, and there dwelt with his rifle as his only confidant. Compared with this, the shanty on Walden Pond has something the air, it must be confessed, of the Hermitage of La Chevrette. We do not believe that the way to a true cosmopolitanism carries one into the woods or the society of musquashes. Perhaps the narrowest provincialism is that of Self ; that of Kleinwinkel is nothing to it. The natural man, like the singing birds, comes out of the forest as inevitably as the natural bear and the wildeat stick there. To seek to be natural implies a consciousness that forbids all 
naturalness forever. It is as casy - and no easier - to be natural in a salon as in a swamp, if one do not aim at it, for what we call unuaturalness always has its spring in a man's thinking too much about himself. "It is impossible," said 'Turgot, "for a vulgar man to be simple."

We look upon a great deal of the modern sentimentalism about Nature as a mark of discase. It is one more symptom of the general liver-complaint. To a man of wholesome constitution the wilderness is well enough for a mood or a vacation, but not for a habit of life. Those who have most loudly advertised their passion for seclusion and their intimacy with nature, from Petrarch down, have been mostly sentimentalists, unreal men, misanthropes on the spindle side, solacing an uneasy suspicion of themselves by professing contempt for their kind. They make demands on the world in advance proportioned to their inward measure of their own merit, and are angry that the world pays only by the visible measure of performance. It is true of Rousseau, the modern founder of the sect, true of Saint Pierre, his intellectual child, and of Châteaubriand, his grandchild, the inventor, we might almost say, of the primitive forest, and who first was touched by the solemn falling of a tree from natural decay in the windless silence of the woods. It is a very shallow view that affirms trees and rocks to be heulthy, and cannot see that men in communities are just as true to the laws of their organization and destiny; that can tolerate the puffin and the fox, but not the fool and the knave; that would shun politics because of its demagogues, and snuff up the stench of the obscene fungus. The divine life of Nature is more wonderful, more various, more sublime in man than in any other of her works, and the wisdom that is gained by commerce with men, as Montaigne and Shakespeare 
gained it, or with one's own soul among men, as Dante, is the most delightful, as it is the most precious, of all. In outward nature it is still man that interests us, and we care far less for the things seen than the way in which poetic eyes like Wordsworth's or Thoreau's see them, and the reflections they cast there. To hear the to-do that is often made over the simple fact that a man sces the image of himself in the outward world, one is reminded of a sarage when he for the first time catches a glimpse of himself in a looking-glass. "Venerable child of Nature," we are tempted to say, "to whose science in the invention of the tobacco-pipe, to whose art in the tattooing of thine undegenerate hide not yet enslared by tailors, we are slowly striving to climb back, the miracle thou beholdest is sold in my unhappy country for a shilling!" If matters go on as they have done, and everybody must needs blab of all the favors that have been done him by roadside and river-brink and woodland walk, as if to kiss and tell were no longer treachery, it will be a positive refreshment to meet a man who is as superbly indifferent to Nature as she is to him. By and by we shall have John Smith, of No.-12 -12th Strect, advertising that he is not the J. S. who saw a cow-lily on Thursday last, as he never saw one in his life, would not see one if he could, and is prepared to prove an alibi on the day in question.

Solitary communion with Nature does not seem to have been sanitary or sweetening in its influence on Thoreau's character. On the contrary, his letters show him more eynical as he grew older. While he studied with respectful attention the minks and woodchucks, his neighbors, he looked with utter contempt on the august drama of destiny of which his country was the scene, and on which the curtain had already rison. $\mathrm{Ho}_{0}$ 
was converting us back to a state of nature "so eloquently," as Voltaire said of Rousseau, "that he almost persuaded us to go on all fours," while the wiser fates were making it possible for us to walk erect for the first time. Had he conversed more with his fellows, his sympathies would have widened with the assurance that his peculiar genius had more appreciation, and his writings a larger circle of readers, or at least a warmer one, than he dreamed of. We have the highest testimony* to the natural sweetness, sincerity, and nobleness of his temper, and in his books an equally irrefragable one to the rare quality of his mind. He was not a strong thinker, but a sensitive feeler. Yet his mind strikes us as cold and wintry in its purity. A light snow has fallen everywhere in which he seems to come on the track of the shier sensations that would elsewhere leave no trace. We think greater compression would have done more for his fame. A feeling of sameness comes over us as we read so much. Trifles are recorded with an overminute punctuality and conscientioușness of detail. $\mathrm{He}$ records the state of his personal thermometer thirteen times a day. We cannot help thinking sometimes of the man who

"Watches, starves, freezes, and sweats

To learn but catechisms and alphabets

Of unconcerning things, matters of fact,"

and sometimes of the saying of the Persian poet, that "when the owl would boast, he boasts of catching mice at the edge of a hole." We could readily part with some of his affectations. It was well enough for Pythagoras to say, once for all, "When I was Euphorbus at the siege of Troy"; not so well for Thoreau to travesty it into " When I was a shepherd on the plains of sions." 
Assyria." A naive thing said over again is anything but naive. But with every exception, there is no writing comparable with Thoreau's in kind, that is comparable with it in degree where it is best; where it disengages itself, that is, from the tangled roots and dead leaves of a second-hand Orientalism, and runs limpid and smooth and broadening as it runs, a mirror for whaterer is grand and lovely in both worlds.

George Sand says neatly, that "Art is not a study of positive reality," (actuality were the fitter word,) "but a seeking after ideal truth." It would be doing very inadequate justice to Thorean if we left it to be inferred that this ideal element did not exist in him, and that too in larger proportion, if less obtrusive, than his nature-worship. He took nature as the mountain-path to an ideal world. If the path wind a good deal, if he record too faithfully every trip over a root, if he botanize somewhat wearisomely, he gives us now and then superb outlooks from some jutting erag, and brings us out at last into an illimitalle ether, where the lreathing is not difficult for those who have any true touch of the climbing spirit. His shanty-life was a mere impossibility, so far as his own conception of it goes, as an entire independency of mankind. The tub of Diogenes had a sounder bottom. Thoreau's experiment actually presupposed all that complicated civilization which it theoretically aljured. He squatted on another man's land; he borrows an axe ; his boards, his nails, his bricks, his mortar, his books, his lamp, his fish-hooks, his plough, his hoe, all turn state's evidence against him as an accomplice in the sin of that artificial cirilization which rendered it possible that such a person as Henry D. Thoreau should exist at all. Magnis temen exciclit ausis. His aim was a noble and a useful one, in the direction of "plain living and high thinking." It was a practical sermon on Emerson's text that "things 
are in the saddle and ride mankind," an attempt to solve Carlyle's problem (condensed from Johnson) of "lessening your denominator." His whole life was a rebuke of the waste and aimlessness of our American luxury, which is an abject enslavement to tawdry upholstery. He had "fine translunary things" in him. His better style as a writer is in keeping with the simplicity and purity of his life. We have said that his range was narrow, but to be a master is to be a master. He had caught his English at its living source, among the poets and prose-writers of its best days ; his literature was extensive and recondite; his quotations are always nuggets of the purest ore: there are sentences of his as perfect as anything in the language, and thoughts as clearly crystallized; his metaphors and images are always fresh from the soil ; he had watched Nature like a detective who is to go upon the stand; as we read him, it seems as if all-out-of-doors had kept a diary and become its own Montaigne; we look at the landscape as in a Claude Lorraine glass; compared with his, all other books of similar aim, even White's "Selborne," seem dry as a country clergyman's meteorological journal in an old almanac. He belongs with Donne and Browne and Novalis; if not with the originally creative men, with the scarcely smaller class who are peculiar, and whose leaves shed their invisible thought-seed like ferns. 


\section{SWINBURNE'S TRAGEDIES.}

$\mathrm{RE}$ we really, then, to believe the newspapers for
once, and to doff our critical nightcaps, in which we have comfortably overslept many similar rumors and false alarms, to welcome the advent of a new poet? New poets, to our thinking, are not very common, and the soft columns of the press often make dangerous concessions, for which the marble ones of Horace's day were too stony-hearted. Indeed, we have some well-grounded doubts whether England is precisely the country from which we have a right to expect that most precious of gifts just now. There is hardly enough fervor of political life there at present to ripen anything but the fruits of the literary forcing-house, so fair outwardly and so flavorless compared with those which grow in the hardier open air of a vigorous popular sentiment. Mere wealth of natural endowment is not enough; there must be also the co-operation of the time, of the public genius roused to a consciousness of itself by the necessity of asserting or defending the rital principle on which that consciousness rests, in order that a poet may rise to the highest level of his rocation. The great names of the last gen. cration — Scott, Wordsworth, Byron - represent moods of national thought and fecling, and are therefore more or less truly British poets; just as Guethe, in whose capacious nature, open to every influence of earth and sky, the spiritual fermentation of the eighteenth century settled and clarified, is a European one. A sceptic might 
say, we think, with some justice, that poetry in England was passing now, if it have not already passed, into one of those periods of mere art without any intense convictions to back it, which lead inevitably, and by no long gradation, to the mannered and artificial. Browning, by far the richest nature of the time, becomes more difficult, draws nearer to the all-for-point fashion of the concettisti, with every poem he writes; the dainty trick of Tennyson cloys when caught by a whole generation of versifiers, as the style of a great poet nerer can be; and we have a foreboding that Clough, imperfect as he was in many respects, and dying before he had subdued his sensitive temperament to the sterner requirements of his art, will be thought a hundred years hence to have been the truest expression in verse of the moral and intellectual tendencies, the doubt and struggle towards settled convictions, of the period in which he lived. To make beautiful conceptions immortal by cxquisiteness of phrase, is to be a poet, no doubt; but to be a new poet is to feel and to utter that immanent life of things without which the utmost perfection of mere form is at best only wax or marble. He who can do both is the great poet.

Over "Chastelard, a Tragedy," we need not spend much time. It is at best but the school exercise of a young poet learning to write, and who reproduces in his copy-book, more or less travestied, the copy that has been set for him at the page's head by the authors he most admires. Grace and eren force of expression are not wanting; but there is the obscurity which springs from want of definite intention; the characters are vaguely outlined from memory, not drawn firmly from the living and the nude in actual experience of life; the working of passion is an a priori abstraction from a scheme in the author's mind ; and there is no thought, but only a vehement grasping after thought. The hand is the hand 
of Swinburne, but the roice is the voice of Browning. With here and there a pure strain of sentiment, a genuine touch of nature, the effect of the whole is unpleasant with the faults of the worst school of moderu poetry, - the physically intense school, as we should be inclined to call it, of which Mrs. Browning's "Aurora Leigh" is the worst example, whose muse is a fast young woman with the lavish ornament and somewhat overpowering perfume of the demi-monde, and which pushes expression to the last gasp of sensuous exhaustion. They forget that convulsion is not energy, and that words, to hold fire, must first catch it from rehement heat of thought, while no artificial ferrors of phrase can make the charm work backward to kindle the mind of writer or reader. An overmastering passion no longer entangles the spiritual being of its vietim in the burning toils of a retribution foredoomed in its own nature, purifying us with the terror and pity of a soul in its extremity, as the great master's were wont to set it hefore us; no, it must be fleshly, corporeal, must "bite with small white tecth" and draw blood, to satisfy the craving of our modern inquisitors, who torture language instead of wooing it to confess the secret of its witcheraft. That books written on this theory should be popular, is one of the worst signs of the times; that they should be praised by the censors of literature shows how seldom criticism goes back to first principles, or is eren aware of them, - how utterly it has forgotten its most carnest function of demolishing the high places where the unclean rites of Baal and Ashtaroth usurp on the worship of the one only True and Pure.

"Atalanta in Calydon" is in every respect better than its forerumer. It is a true poem, and seldom breaks from the maidenly reserve which should characterize the higher forms of poetry, even in the keenest energy of expression. If the blank verse be a little mannered and 
stiff, reminding one of Landor in his attempts to reproduce the antique, the lyrical parts are lyrical in the highest sense, graceful, flowing, and generally simple in sentiment and phrase. There are some touches of nature in the mother's memories of Althea, so sweetly pathetic that they go as right to the heart as they came from it, and are neither Greek nor English, but broadly human. And yet, when we had read the book through, we felt as if we were leaving a world of shadows, inhabited by less substantial things than that nether realm of Homer where the very eidolon of Achilles is still real to us in its longings and regrets. These are not characters, but outlines after the Elgin marbles in the thinnest manner of Flaxman. There is not so much blood in the whole of them as would warm the little finger of one of Shakespeare's living and breathing conceptions. We could not help thinking of those exquisite verses addressed by Schiller to Goethe, in which, while he expresses a halftruth so eloquently as almost to make it seem a whole one, he touches unconsciously the weak point of their common striving after a Grecian instead of a purely human ideal.
"Doch leicht gezimmert nur ist Thespis Wagen,
Und er ist gleich dem acheront'schen Kahn;
Nur Schatten und Idole kann er tragen,
Und dräıgt das rohe Leben sich heran,
So droht das leichte Falirzeug umzuschlagen
Das nur die flücht'gen Geister fassen kann;
Der Schein soll nie die Wirklichkeit erreichen
Und siegt Natur, so muss die Kunst entweichen."

The actors in the drama are unreal and shadowy, the motives which actuate them alien to our modern modes of thought and conceptions of character. To a Greek, the element of Fate, with which his imagination was familiar, while it heightened the terror of the catastrophe, would have supplied the place of that impulse in mere 
human nature which our habit of mind demands for its satisfiction. The fulfilment of an oracle, the anger of a deity, the arbitrary doom of some blind and purposeless power superior to man, the avenging of blood to appease an injured ghost, any one of these might make that seem simply natural to a contemporary of Sophocles which is intelligible to us only by study and reflection. It is not a little curious that shakespeare should have made the list of the motives we have just mentioned, and which was conclusive for Orestes, insufficient for Hamlet, who so perfectly typities the introversion and complexity of modern thought as compared with ancient, in dealing with the problems of life and action. It was not perhaps without intention (for who may venture to assume a want of intention in the world's highest poetic genius at its full maturity ?) that Shakespeare brings in his hero fresh from the University of Wittenberg, where Luther, who entailed upon us the responsibility of prirate judgment, had been Professor. The dramatic motive in the "Electrn" and "Hamlet" is essentially the same, but what a difference between the straightforwarl bloody-mindedness of Orestes and the metaphysical punctiliousness of the Dane! Yet each was natural in his several way, and each would have been unintelligihle to the audience for which the other was intended. That Fate which the Greeks made to operate from without, we recognize at work within in some vice of character or hereditary predisposition. Hawthorne, the most profoundly ideal genius of these latter days, was continually returning, more or less directly, to this theme; and his "Marble Faun," whether consciously or not, illustrates that invasion of the resthetic by the moral which has confused art by dividing its allegiance, and dethroned the old dynasty without as yet firmly establishing the new in an acknowledged legitimacy. 
"Atalanta in Calydon" shows that poverty of thought and profusion of imagery which are at once the defect and the compensation of all youthful poetry, even of Shakespeare's. It seems a paradox to say that there can be too much poetry in a poem, and yet this is a fault with which all poets begin, and which some never get over. But "Atalanta" is hopefully distinguished, in a rather remarkable way, from most early attempts, by a sense of furm and proportion, which, if seconded by a seasonable ripening of other faculties, as we may fairly expect, gives promise of rare achievement hereafter. Mr. Swinburne's power of assimilating style, which is, perhaps, not so auspicious a symptom, strikes us as something marvellous. The argument of his poem, in its quaint archaism, would not need the change of a word or in the order of a period to have been foisted on Sir Thomas Nalory as his own composition. The choosing a theme which Eschylus had handled in one of his lost tragedies is justified by a certain Eschylean flavor in the treatment. The opening, without deserving to be called a mere imitation, recalls that of the "Agamemnon," and the chorus has often an imaginative lift in it, an ethereal charm of phrase, of which it is the highest praise to say that it reminds us of him who soars over the other Greek tragedians like an eagle.

But in spite of many merits, we cannot help asking ourselves, as we close the book, whether "Atalanta" can be called a success, and if so, whether it be a success in the right direction. The poem reopens a question which in some sort touches the very life of modern literature. We do not mean to renew the old quarrel of Fontenelle's day as to the comparative merits of ancients and moderns. That is an affair of taste, which does not admit of any authoritative settlement. Our concern is about a principle which certainly demands a fuller discussion, 
and which is important enough to deserve it. Do we show our appreciation of the Greeks most wisely in attempting the mechinical reproduction of their forms, or by endeavoring to comprehend the thoughtful spirit of full-grown manhood in which they wrought, to kindle ourselves by the emulation of it, and to bring it to bear with all its plistic force upon our wholly new conditions of life and thought? It seens to us that the question is answered by the fact, patent in the history of all the fine arts, that every attempt at reproducing a bygone excellence by external imitation of it, or even by applying the rules which analytic criticism has formulated from the study of it, has resulted in producing the artificial, and not the artistic. That most subtile of all essences in physical organization, which elndes chemist, anatomist, and microscopist, the life, is in asthetics not less shy of the critic, and will not come forth in obedience to his most learned spells, for the very good reason that it cannot, beciuse in all works of art it is the joint product of the artist and of the time. Faust may believe he is gazing on "the face that launched a thousand ships," but Mephistopheles knows very well that it is only shadows that he has the skill to conjure. He is not merely the spirit that ever denies, but the spirit also of discontent with the present, that material in which every man shall work who will achieve realities and not their hollow semblance. The true anachronism, in our opinion, is not in Shakespeare's making Ulysses talk as Lord Bacon might, but in attempting to make him spoak in a dialect of thought utterly dead to all present comprehension. Ulysies was the type of long-headedness; and the statecraft of an Ithacan cateran would have seemed as childish to the age of Elizabeth and Burleigh as it was naturally sufficing to the first hearers of Homer. Ulysses, living in Florence during the fifteenth century, 
might have been Macchiavelli; in France, during the seventeenth, Cardinal Richelieu; in America, during the nineteenth, Abraham Lincoln, but not Ulysses. Truth to nature can be reached ideally, never historically; it must be a study from the life, and not from the scholiasts. Theocritus lets us into the secret of his good poctry, when he makes Daphnis tell us that he preferred his rock with a view of the Siculian Sea to the kingdom of Pelops.

It is one of the marvels of the human mind, this sorcery which the fiend of technical imitation weaves about his victims, giving a phantasmal Helen to their arms, and making an image of the brain seem substance. Men still pain themselves to write Latin verses, matching their wooden bits of phrase together as children do dissected maps, and measuring the value of what they have done, not by any standard of intrinsic merit, but by the difficulty of doing it. Petrarch expected to be known to posterity by his Africa. Gray hoped to make a Latin poem his monument. Goethe, who was classic in the only way it is now possible to be classic, in his "Hermann and Dorothea," and at least Propertian in his "Roman Idyls," wasted his time and thwarted his creative energy on the mechanical mock-antique of an unreadable "Achilleis." Landor prized his waxen "Gebirus Rex" above all the natural fruits of his mind; and we have no doubt that, if some philosopher should succeed in accomplishing Paracelsus's problem of an artificial homunculus, he would dote on this mishegotten babe of his science, and think him the only genius of the family. We cannot over-estimate the value of some of the ancient classics, but a certain amount of superstition about Greek and Latin has come down to us from the revival of learning, and seems to hold in mortmain the intellects of whoever has, at some time, got a smattering 
of them. Men quote a platitude in either of those tongues with a relish of conviction as droll to the uninitiated as the knighthood of free-masonry. Horace Walpole's nephew, the Earl of Orford, when he was in his cups, used to have Statius read aloud to him every night for two hours by a tipsy tradesman, whose hiccupings threw in here and there a kind of cxsural pause, and found some strange mystery of sweetness in the disquantitied syllables. So powerful is this hallucination that we can conceive of festinalente as the favorite maxim

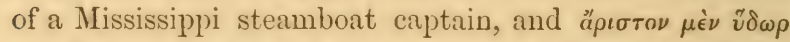
cited as conclusive by a gentleman for whom the bottle before him reversed the wonder of the stereoscope, and substituted the Gascon $v$ for the $b$ in binocular.

Something of this singular superstition has infected the minds of those who confound the laws of conventional limitation which governed the practice of Greek authors in dramatic composition - laws adapted to the habits and traditions and preconceptions of their andience with that sense of ideal form which made the Greeks masters in art to all sueceeding generations. Aristophanes is beyond question the highest type of pure comedy, etherealizing his humor by the infusion, or intensifying it by the contrast of poetry, and deodorizing the personality of his sarcasm by a sprinkle from the clearest springs of fancy. His satire, aimed as it was at typical characteristics, is as fresh as ever; but we doubt whether an Aristophanic drama, retaining its exact form, but adapted to present events and personages, would keep the stage as it is kept by "The Rivals," for example, immeasurably inferior as that is in every element of genius except the prime one of liveliness. Something similar in purpose to the parabasis was essayed in one, at least, of the comedies of Beaumont and Fletcher, and in our time by Tieck ; but it took, of necessity, a differ 
ent form of expression, and does not scem to have been successful. Indeed, the fact that what is called the legitimate drama of modern times in England, Spain, and France has been strictly a growth, and not a manufacture, that in each country it took a different form, and that, in all, the period of its culminating and beginning to decline might be measured by a generation, seems to point us toward some natural and inevitable law of human nature, and to show that, while the principles of art are immutable, their application must accommodate itself to the material supplied them by the time and by the national character and traditions. The Spanish tragedy inclines more toward the lyrical, the French toward the epical, the English toward the historical, in the representation of real life ; the Spanish and English agree in the Teutonic peculiarity of admitting the humorous offset of the clown, though in the one case he parodies the leading motive of the drama, and represents the self-consciousness of the dramatist, while in the other he heightens the tragic effect by contrast, (as in the grave-digging scene of Hamlet,) and suggests that stolid but wholesome indifference of the general life - of what, for want of a better term, we call Nature - to the sin and suffering, the weakness and misfortunes of the individual man. All these nations had the same ancient examples before them, had the same reverence for antiquity, yet they involuntarily deviated, more or less happily, into originality, success, and the freedom of a living creativeness. The higher kinds of literature, the only kinds that live on because they had life at the start, are not, then, it should seem, the fabric of scholarship, of criticism, diligently studying and as diligently copying the best models, but are much rather born of some genetic principle in the character of the people and the age which produce them. One drop of ruddy human 
blood puts more life into the veins of a poem, than all the delusive aurum potabile that can be distilled out of the choicest library.

The opera is the closest approach we have to the ancient drama in the essentials of structure and presentation; and could we have a libretto founded on a national legend and written by one man of genius to be filled out and accompanied by the music of another, we might hope for something of the same effect upon the stage. But themes of universal familiarity and interest are rare, - Don Giovamni and Faust, perhaps, most nearly, though not entirely, fulfilling the required conditions, - and men of genius rarer. The oratorio seeks to evade the difficulty by choosing Scriptural subjects, and it may eertainly be questioned whether the day of popular mythology, in the sense in which it subserves the purposes of epic or dramatic poetry, be not gone by forever. Longfellow is driven to take refuge among the red men, and Temnyson in the Cambro-Breton cyclus of Arthur; but it is impossible that such themes should come so intimately home to us as the semi-fabulous stories of their own ancestors did to the Greeks. The most successful attempt at reproducing the Greek tragedy, both in theme and treatment, is the "Samson Agonistes," as it is also the most masterly piece of English versification. Goethe admits that it alone, among modern works, has caught life from the breath of the antique spirit. But he failed to see, or at least to give, the reason of it; probably failed to see it, or he would never have attempted the "Iphigenia." Milton not only subjected himself to the structural requirements of the Attic tragedy, but with a true poetic instinct arailed himself of the striking advantage it had in the choice of a sulject. No popular tradition lay near enough to him for his purpose; none united in itself 
the essential requisites of human interest and universal belief. He accordingly chose a Jewish mythus, very near to his own heart as a blind prisoner, betrayed by his wife, among the Philistines of the Restoration, and familiar to the earliest associations of his hearers. This sulject, and this alone, met all the demands both of living poetic production and of antique form, - the action grandly simple, the personages few, the protagonist at once a victim of divine judgment and an executor of divine retribution, an intense personal sympathy in the poet himself, and no strangeness to the habitual prepossessions of those he addressed to be overcome before he could touch their hearts or be sure of aid from their imaginations. To compose such a drama on such a theme was to be Greek, and not to counterfeit it; for Samson was to Milton traditionally just what Herakles was to Sophocles, and personally far more. The "Agonistes" is still fresh and strong as morning, but where are "Caractacus" and "Elfrida"? Nay, where is the far better work of a far abler man, where is "Merope" ? If the frame of mind which performis a deliberate experiment were the same as that which produces poetry vitalized through and through by the conspiring ardors of every nobler passion and power of the soul, then "Norope" might have had some little space of life. But without color, withont harmonious rhythm of movement, with less passion than survived in an average Grecian ghost, and all this from the very theory of her creation, she has gone back, a shadow, to join her shadowy Italian and French namesakes in that limbo of things that would be and cannot be. Mr. Arnold but retraces, in his Preface to "Merope," the arguments of Mason in the letters prefixed to his classical experiments. What finds defenders, but not readers, may be correct, classic, right in principle, but it is not 
poetry of that absolute kind which may and does help men, but needs no help of theirs; and such surely we have a right to demand in tragedy, if nowhere else. We should not speak so unreservedly if we did not set a high value on Mr. Arnold and his poetic gift. But "Merope" has that one fault against which the very gods, we are told, strive in vain. It is dull, and the seed of this dulness lay in the system on which it was written.

Pscudo-classicism takes two forms. Sometimes, as Mr. Landor has done, it attempts truth of detail to ancient scenery and manners, which may be attained either by hard reacling and good memory, or at a cheaper rate from such authors as Becker. The "Moretum," once attributed to Virgil, and the idyl of Theocritus lately chosen as a text by Mr. Arnold, are interesting, because they describe real things; but the mock-antique, if not true, is nothing, and how true such poems are likely to be we can judge by "Punch's" success at Yankeeisms, by all England's accurate appreciation of the mamners and minds of a contemporary people one with herself in language, laws, religion, and literature. The eye is the only note-book of the true poet; but a patchwork of second-hand momories is a laborious futility, hard to write and harder to read, with about as much nature in it as a dialogue of the Deipnosophists. Alexander's bushel of peas was a criticism worthy of Aristotle's pupil. We should reward such writing with the gift of a classical dictionary. In this idyllic kind of poetry also we have a classic, because Goldsmith went to nature for his "Deserted Villaye," and borrowed of tradition nothing but the poetic diction in which he described it. This is the only method by which a poet may surely reckon on ever becoming an ancient himself. When we heard it said once that a certain poem might have been 
written by Simonides, we could not help thinking that, if it were so, then it was precisely what Simonides could never have written, since he looked at the world through his own eyes, not through those of Linus or Hesiod, and thought his own thoughts, not theirs, or we should never have had him to imitate.

Objections of the same nature, but even stronger, lie against a servile copying of the form and style of the Greek tragic drama, and yet more against the selection of a Greek theme. As we said before, the life we lead, and the views we take of it, are more complex than those of men who lived five centuries before Christ. They may be better or worse, but, at any rate, they are different, and irremediably so. The idea and the form in which it naturally embodies itself, mutually sustaining and invigorating each other, cannot be divided without endangering the lives of both. For in all real poetry the form is not a garment, but a body. Our very passion has become metaphysical, and speculates upon itself. Their simple and downright way of thinking loses all its savor when we assume it to ourselves by an effort of thought. Human nature, it is true, remains always the same, but the displays of it change; the habits which are a second nature modify it inwardly as well as outwardly, and what moves it to passionate action in one age may leave it indifferent in the next. Betwreen us and the Greeks lies the grave of their murdered paganism, making our minds and theirs irreconcilable. Christianity as steadily intensifies the selfconsciousness of man as the religion of the Greeks must have turned their thoughts array from themselves to the events of this life and the phenomena of nature. We cannot even conceive of their conception of Phoibos with any plausible assurance of coming near the truth. To take lesser matters, since the invention of printing 
and the cheapening of books bave made the thought of all ages and nations the common property of educated men, we cannot so dis-saturate our minds of it as to be keenly thrilled in the modern imitation with those commonplaces of proverbial lore in which the chorus and secondary characters are apt to indulge, though in the original they may interest us as being natural and characteristic. In the German-silver of the modern we get something of this kind, which does not please us the more by being cut up into single lines that recall the outward semblance of some pages in Sophocles. We find it cheaper to make a specimen than to borrow one.

CHorus. Foolish who bites off nose, his face to spite.

Outis. Who fears his fate, him Fate shall one day spurn.

CHorus. The gods themselves are pliable to Fate.

Outis. The strong self-ruler dreads no other sway.

CHorus. Sometimes the shortest way goes most about.

Outis. Why fetch a compass, having stars within?

Chorus. A shepherd once, I know that stars may set.

Ouris. That thou led'st sheep fits not for leading men.

Chorus. To sleep-sealed eyes the wolf-dog barks in vain.

We protest that we have read something very like this, we will not say where, and we might call it the battledoor and shuttlecock style of dialogme, except that the players do not seem to have any manifest relation to each other, but each is intent on kecping his own bit of feathered cork continually in the air.

The first sincerely popular yearning toward antiquity, the first germ of Schiller's "Gütter Griechenland's" is to be found in the old poem of Tanhäuser, very near1y coincident with the beginnings of the Reformation. And if we might allegorize it, we should say that it typified precisely that longing after Venus, under her other name of Charis, which represents the relation in which modem should stand to ancient art. It is the grace of the Greeks, their sense of proportion, their dis. 
taste for the exaggerated, their exquisite propriety of phrase, which steadies imagination without cramping it, - it is these that we should endeavor to assimilate without the loss of our own individuality. We should quicken our sense of form by intelligent sympathy with theirs, and not stiffen it into formalism by a servile surrender of what is genuine in us to what vas genuine in them. "A pure form," says Schiller, "helps and sustains, an impure one hinders and shatters." But wo should remember that the spirit of the age must enter as a modifying principle, not only into ideas, but into the best manmer of their expression. The old bottles will not always serve for the new wine. A principle of life is the first requirement of all art, and it can only be communicated by the touch of the time and a simple faith in it; all else is circumstantial and secondary. The Greek tragedy passed through the three natural stages of poetry, - the imaginative in Eschylus, the thoughtfully artistic in Sophocles, the sentimental in Euripides, - and then died. If people could only learn the general applicability to periods and schools of what young Mozart says of Gellert, that "he had written no poetry since his death"! No effort to raise a defunct past has ever led to anything but just enough galvanic twitching of the limbs to remind us unpleasantly of life. The romantic movement of the school of German poets which succeeded Goethe and Schiller ended in extravagant unreality, and Goethe himself with his cnerring common-sense, has given us, in the second part of Faust, the result of his own and Schiller's common striving after a Grecian ideal. Euphorion, the child of Faust and Helen, falls dead at their feet; and Helen herself soon follows him to the shades, leaving only her mantle in the hands of her lover. This, he is told, shall lift him above the earth. We fancy we can interpret the 
symbol. Whether we can or not, it is certainly sugges tive of thought that the only immortal production of the greatest of recent poets was conceived and carried out in that Gothic spirit and form from which he was all his life struggling to break loose. 


\section{CH A UCER。*}

WILL it do to say anything more about Chaucer? Can any one hope to say anything, not new, but even fresh, on a topic so well worn? It may well be doubted; and yet one is always the better for a walk in the morning air, - a medicine which may be taken over and over again without any sense of sameness, or any failure of its invigorating quality. There is a pervading wholesomeness in the writings of this man, - a vernal property that soothes and refreshes in a way of which no other has ever found the secret. I repeat to myself a thousand times, -

"Whan that Aprilë with his showrës sotë

The droughte of March hath percëd to the rotë,

And bathëd every veine in swich licour

Of which vertue engendered is the flour, -

When Zephyrus eek with his swetë breth

Enspirëd hath in every holt and heth

The tender croppës, and the yongë sonne

Hath in the ram his halfë cors yronne,

And smalë foulës maken melodië," -

and still at the thousandth time a breath of uncontami-

* Publications of the Chaucer Society. London. 1869-70.

Étude sur G. Chaucer considéré comme imitateur des Trouvères. Par E. G. Saxdras, Agrégé de l'Université. Paris: Auguste Dusand. 1859. 8vo. pp. 298.

Genffrey Chnucer's Canterbury-Geschichten, uebersetzt in den V'ersmassen der Urschrift, und durch Einleitung und Anmerkungen erläutert. Von Wrliela Hertzberc. Hildburghausen. 1866. 12mo. pp. 674.

Chaucer in Seinen Beziehungen zur italienischen Literatur. Inaugural-Dissertation zur Erlangung der Doctorwürde. Von ALFons KissNER. Bonn. 1867. 8vo. pp. 81. 
nate springtide seems to lift the hair upon my forehead. If hore be not the largior ether, the serene and motionless atmosphere of classical antiquity, we find at loast the seclusum nemus, the domos placidus, and the oubliunce, as Froissart so sweetly calls it, that persuade us we are in an Elysimm none the less sweet that it appeals to our more purely human, one might almost say domestie, sympathies. We may say of Chancer's muse, as Overbury of his milkmaid, "her breath is her own, which seents all the year long of June like a new-made haycoek." 'The most hardened roué of literature cim searce confront these simple and winning graces without fecling somewhat of the unworn sentiment of his youth revive in him. Modern imaginative literature has become so self-conscious, and therefore so melancholy, that Art, which should be "the world's sweet inn," whither we repair for refreshment and repose, has become rather a watering-place, where one's own private tonch of the liver-complaint is exasperated by tho affuence of other sufferer's whose talk is a narrative of morbid symptoms. Poets have forgotten that the first lesson of literature, no less than of life, is the learning how to burn your own smoke; that the way to be original is to be healthy; that the fresh color, so delightful in all good writing, is won by escaping from the fixed air of self into the brisk atmosphere of universal sentiments; and that to make the common marvellous, as if it were a revelation, is the test of genius. It is good to retreat now and then beyond earshot of the introspective confidences of modern literature, and to lose ourselves in the gracious worldliness of Chaucer. Here was a healthy and hearty man, so genuine that he need not ask whether he were genuine or no, so sineere as quite to forget his own sincerity, so truly pions that he conld be happy in the best world that God chose to make, so humane that he loved eren the foibles of his kind. Here 
was a truly epic poet, without knowing it, who did not waste time in considering whether his age were good or bad, but quietly taking it for granted as the best that ever was or could be for him, has left us such a picture of contemporary life as no man ever painted. "A perpetual fountain of good-sense," Dryden calls him, yes, and of good-humor, too, and wholesome thought. He was one of those rare authors whom, if we had met him under a porch in a shower, we should have preferred to the rain. He could be happy with a crust and springwater, and could see the shadow of his benign face in a flagon of Gascon wine without fancying Death sitting opposite to cry Supernaculum! when he had drained it. He could look to God without abjectness, and on man without contempt. The pupil of manifold experience, - scholar, courtier, soldier, ambassador, who had known poverty as a housemate and been the companion of princes, - his was one of those happy temperaments that could equally enjoy both halves of culture, - the world of books and the world of men.

"Unto this day it doth mine hertë boote,

That I have had my world as in my time!"

The portrait of Chancer, which we owe to the loving regret of his disciple Occlere, confirms the judgment of him which we make from his works. It is, I think, more engaging than that of any other poct. The downcast eyes, half sly, half meditative, the sensuous mouth, the broad brow, drooping with weight of thought, and yet with an incxpugnable youth shining out of it as from the morning forehead of a boy, are all noticeable, and not less so their harmony of placid tenderness. We are struck, too, with the smoothness of the face as of one who thought easily, whose phrase flowed naturally, and who had never puckered his lrow orer an ummanageal)le verse.

Nothing has been added to our knowledge of Chaucer's 
life since Sir Harris Nicholas, with the help of original records, weeded away the fictions by which the few facts were choked and overshadowed. We might be sorry that no confirmation has been found for the story, fathered on a certain phantasmal Mr. Buckley, that Chancer was "fined two shillings for beating a Franciscan friar in Fleet Street," if it were only for the alliteration; but we refuse to give up the meeting with Petrarch. All the probabilities are in its faror. That Chancer, being at Milan, should not have found occasion to ride across so far as Padua, for the sake of seeing the most famous literary man of the day, is incredible. If Froissart could journey on horselnack through Scotland and ITales, surely Chancer, whose curiosity was as lively as his, might have ventured what would have been a mere pleasure-trip in comparison. I cannot easily bring myself to believe that he is not giving some touches of his own character in that of the Clerk of Oxford:-

"For him was liefer have at his bed's head

A twenty bookës clothed in black and red

Of Aristotle and his philosophië

Than robës rich, or fiddle or psaltrië:

But although that he were a philosopher

Yet had he but a little gold in coffer:

Of study took he mostë care and heed;

Not one word spake he morë than was need:

All that he spake it was of high prudèncë,

And short and quick, and full of great sentencë;

Sounding in moral virtue was his speech

And gladly would he learn and gladly teach."

That, himself as plump as Horace, he should have described the Clerk as being lean, will be no objection to those who remember how carefully Chaucer effaces his own personality in his great poem. Our chief debt to Sir Harris Nicholas is for having disproved the story that Chaucer, irnprisoned for complicity in the insurrection of John of Northampton, had set himself free by betraying 
his accomplices. That a poet, one of whose leading qualities is his good sense and moderation, and who should seem to have practised his own rule, to

"Fly from the press and dwell with soothfastness;

Suffice thee thy good though it be small,"

should have been concerned in any such political excesses, was improbable enough; but that he should add to this the baseness of broken faith was incredible except to such as in a doubtful story

"Demen gladly to the badder end."

Sir Harris Nicholas has proved by the records that the fabric is baseless, and we may now read the poet's fine verse,

"Truth is the highest thing a man may keep,"

without a pang. We are thankful that Chaucer's shoulders are finally discharged of that weary load, "The Testament of Love." * The later biographers seem inclined to make Chancer a younger man at his death in 1400 than has hitherto been supposed. Herr Hertzberg even puts his birth so late as 1340 . But, till more conclusive evidence is producod, we shall adhere to the received dates as on the whole more consonant with the probabilities of the case. The monument is clearly right as to the year of his death, and the chances are at least even that both this and the date of birth were copied from an older inscription. The only counter-argument that has much force is the manifestly unfinished condition of the "Canterbury Tales." That a man of serenty odd could have put such a spirit of youth into those

* Tyrwhitt doubted the authenticity of "The Flower and the Leaf" and "The Cuckoo and the Nightingale." To these Mr. Bradshaw (and there can be no higher authority) would add "The Court of Love," the "Dream," the "Praise of Woman," the "Romaunt of the Rose," and several of the shorter poems. To these doubtful productions there is strong ground, both moral and wsthetic, for adding the "Parson's Tale." 
matchless prologues will not, however, surprise those who reurember Dryden's second spring-time. It is plain that the notion of giving unity to a number of disconnected stories by the device which Chaucer adopted was an afterthonght. These stories had been written, and some of them even published, at periods far asunder, and without any reference to comnection among themselves. The prologues, and those parts which internal evidence justifies us in taking them to have been written after the thread of plan to string them on was conceived, are in every way more mature, - in knowledge of the world, in easy mastery of verse and language, and in the overpoise of sentiment by julgment. They may with as much probability be referred to a green old age as to the middle-life of a man who, upon any theory of the dates, was certainly slow in ripening.

The formation of a Chaucer Society, now four centuries and a half after the poet's death, gives suitable occasion for taking a new olsservation of him, as of a fixed star, not only in our own, but in the European literary heavens, "whose worth's unknown although his height be taken." The admirable work now doing by this Society, whose establishment was mainly due to the pious zeal of Mr. Furnivall, deserves recognition from all who know how to value the too rare union of accurate scholarship with minute exactness in reproducing the text. The six-text edition of the "Canterbury Tales," giving what is practically equivalent to six manuscript copies, is particularly deserving of gratitude from this side the water, as it for the first time affords to Americans the opportunity of independent critical study and comparison. This beautiful work is fittingly inscribed to our comntryman, Professor Child, of Harvard, a lover of Chancer, "so proved by his wordës and his werke," 
who has done more for the great poet's memory than any man since Tyrwhitt. We earnestly hope that the Society may find enough support to print all the remaining manuscript texts of importance, for there can hardly be any one of them that may not help us to a valuable hint. The works of Mrr. Sandras and Herr Hertzberg show that this is a matter of interest not merely or even primarily to English scholars. The introduction to the latter is one of the best essays on Chaucer yet written, while the former, which is an inrestigation of the French and Italian sources of the poet, supplies us with much that is new and worth having as respects the training of the poet, and the obstacles of fashion and taste through which he had to force his way before he could find free play for his native genius or even so much as arrive at a consciousness thereof. M. Sandras is in every way a worthy pupil of the accomplished M. Victor Leclere, and, though he lays perhaps a little too much stress on the indebtedness of Chaucer in particulars, shows a singularly intelligent and clear-sighted eye for the general grounds of his claim to greatness and originality. It is these grounds which I propose chiefly to examine here.

The first question we put to any poet, nay, to any so-called national literature, is that which Farinata addressed to Dante, Chi fur li maggior tui? Here is no question of plagiarism, for pocms are not made of words and thoughts and images, but of that something in the poct himself which can compel them to obey him and move to the rhythm of his nature. Thus it is that the new poet, however late he come, can never be forestalled, and the ship-builder who built the pinnace of Columbus has as much claim to the discovery of America as he who suggests a thought by which some other man opens new worlds to us has to a share in that achievement by 
him unconceived and inconceivable. Chaucer undoubt. edly began as an imitator, perhaps as mere translator, serving the needful apprenticeship in the use of his tools. Children learn to speak by watching the lips and eatching the words of those who know how already, and poets learn in the same way from their elders. They import their raw material from any and everywhere, and the question at last comes down to this, - whether an author have original force enough to assimilate all he has acquired, or that be so overmastering as to assimilate him. If the poet turn out the stronger, we allow him to help himself from other people with wonderful equanimity. Should a man discorer the art of transmuting metals and present us with a lump of gold as large as an ostrich-egg, would it be in human nature to inquire too nicely whether he had stolen the lead?

Nothing is more certain than that great poets are not sudden prodigies, but slow results. As an oak profits by the foregone lives of immemorial regetable races that have worked-over the juices of earth and air into organic life out of whose dissolution a soil might gather fit to maintain that nobler birth of nature, so we may be sure that the genius of every remembered poet drew the forces that built it up out of the decay of a long succession of forgotten ones. Nay, in proportion as the genius is rigorous and original will its indebtedness be greater, will its roots strike decper into the past and grope in remoter fields for the rirtue that must sustain it. Indeed, if the works of the great poets teach anything, it is to hold mere invention somewhat cheap. It is not the finding of a thing, but the making something out of it after it is found, that is of consequence. $\Lambda \mathrm{c}$ cordingly, Chancer, like Shakespeare, invented almost nothing. Whererer he found anything directed to Geoffrey Chaucer, he took it and made the most of it. 


\section{CHAUCER.}

It was not the subject treated, but himself, that was the new thing. Cela m'appartient de droit, Molière is reported to have said when accused of plagiarism. Chaucer pays that "usurious interest which genius," as Coleridge says, "always pays in borrowing." The characteristic touch is his own. In the famous passage about the caged bird, copied from the "Romaunt of the Rose," the "gon eten wormes" was added by him. We must let him, if he will, eat the heart out of the literature that had preceded him, as we sacrifice the mulberryleaves to the silkworm, because he knows how to convert them into something richer and more lasting. The question of originality is not one of form, but of substance, not of cleverness, but of imaginative power. Given your material, in other words the life in which you live, how much can you see in it? For on that depends how much you can make of it. Is it merely an arrangement of man's contrivance, a patchwork of expediencies for temporary comfort and conrenience, good enough if it last your time, or is it so much of the surface of that erer-flowing deity which we call Time, wherein we catch such fleeting reflection as is possible for us, of our relation to perdurable things? This is what makes the difference between Eschylus and Euripides, between Shakespeare and Fletcher, between Goethe and Heine, between literature and rhetoric. Something of this depth of insight, if not in the fullest, yet in 110 inconsiderable measure, characterizes Chaucer. We must not let his playfulness, his delight in the world as mere spectacle, mislead us into thinking that he was incapable of serious purpose or insensible to the deeper meanings of life.

There are four principal soures from which Chancer may be presumed to have drawn for poctical suggestion or literary culture, - the Latins, the Troubadours, the 
Trouveres, and the Italians. It is only the two latter who can fairly claim any immediate influence in the direction of his thought or the formation of his style. The only Latin poet who can be supposed to have influenced the spirit of mediseval literature is Ovid. In his sentimentality, his lore of the marvellous and the picturesque, he is its natural precursor. The analogy between his Fasti and the versified legends of saints is more than a fanciful one. He was certainly popular with the poets of the thirteenth and fourteenth centuries. Virgil had welluigh become mythical. The chief merit of the Provençal poets is in having been the first to demonstrate that it was possible to write with elegance in a modern dialect, and their interest for us is mainly as forerumners, as indications of tendency. Their literature is prophecy, not fulfilment. Its formal sentiment culminated in Laura, its ideal aspiration in Beatrice. Shakespeare's hundred and sixth sonnet, if, for the imaginary mistress to whom it was addressed, we substitute the muse of a truer conception and more perfected utterance, represents exactly the feeling with which we read Provençal poetry :-

"When in the chronicle of wasted Time I see descriptions of the fairest wights And beauty making beautiful old rhyme In praise of ladies dead and lovely knights,

I see their antique pen would have expressed Even such a beauty as you master now;

So all their praises are but prophecies Of this our time, all you prefiguring, And, for they looked but with divining eyes, They had not skill enough your worth to sing."

It is astonishing how little of the real life of the time we learn from the Troubadour's execpt by way of inference and deduction. Their poetry is purely lyric in its most narrow sense, that is, the expression of personal and 
momentary moods. To the fancy of critics who take their cue from tradition, Provençe is a morning sky of early summer, out of which imnumerable larks rain a faint molody (the sweeter because rather half divined than heard too distinctly) over an earth where the dew never dries and the flowers never fade. But when we open Raynouard it is like opening the door of an aviary. We are deafened and confused by a hundred minstrels singing the same song at once, and more than suspect that the flowers they welcome are made of French cambric spangled with dewdrops of prevaricating glass. Bernard de Ventadour and Bertrand de Born are wellnigh the only ones among them in whom we find an original type. Yet the Troubadours undoubtedly led the way to refinement of conception and perfection of form. They were the conduit through which the failing stream of Roman literary tradition flowed into the new channel which mediæval culture was slowly shaping for itself. Without them we could not understand Petrarca, who carried the manufacture of artificial bloom and fictitious dew-drop to a point of excellence where artifice, if ever, may claim the praise of art. Without them we could not understand Dante, in whom their sentiment for woman was idealized by a passionate intellect and a profound nature, till Beatrice becomes a half-human, half-divine abstraction, a woman still to memory and devotion, a disembodied symbol to the ecstasy of thought. The Provençal love-poetry was as abstracted from all sensuality as that of Petrarca, but it stops short of that larger and more gracious style of treatment which has secured him a place in all gentle hearts and refined imaginations forever. In it also woman leads her servants upward, but it is along the easy slopes of conventional sentiment, and no Troubadour so much as dreamed of that loftier region, native to Dante, where the woman 
is subtilized into das Ewig-Weibliche, type of man's finer conscience and nobler aspiration made sensible to him only through her.

On the whole, it would be hard to find anything more tedionsly artificial than the Provençal literature, except the reproduction of it by the Aimesingers. The Tedeschi lurchi certainly did contrive to make something heary as dough out of what was at least light, if not very satisfying, in the canorous dialect of Southern Gaul. But its doom was inevitably predicted in its nature and position, nay, in its very name. It was, and it continues to be, a strictly provinciul literature, imprisoned within extremely narrow intellectual and even geographical limits. It is not race or language that can inflict this leprous isolation, but some defect of sympathy with the simpler and more universal relations of human nature. You cannot shut up Burns in a dialect bristling with archaisms, nor prevent Béranger from setting all pulses a-dance in the least rhythmic and imaginative of modern tongues. The healthy temperament of Chancer, with its breadth of interest in all ranks and phases of social life, could have found little that was sympathetic in the eraporated sentiment and rhetorical punctilios of a school of poets which, with rare exceptions, began and ended in courtly dilettantism.

The refined formality with which the literary product of Provençe is for the most part stamped, as with a trademark, was doubtless the lecacy of Gallo-Roman culture, itself at best derivative and superficial. I think, indeed, that it may well be doulted whether Roman literature, always a half-hardy exotic, could ripen the seeds of living reproduction. The Roman genins was eminently practical, and far more apt for the triumphs of polities and jurisprudence than of art. Supreme elegance it could and did arrive at in Virgil, but, if I may trust my own judgment, it produced but one original 
poet, and that was Horace, who has ever since continued the favorite of men of the world, an apostle to the Gentiles of the mild cynicism of middle-age and an afterdimner philosophy. Though in no sense national, he was, more truly than any has ever been since, till the same combination of circumstances produced Béranger, an urbane or city poet. Rome, with her motley life, her formal religion, her easy morals, her spectacles, her luxury, her suburban country-life, was his muse. The situation was new, and found a singer who had wit enough to turn it to account. There are a half-dozen pieces of Catullus unsurpassed (unless their Greek originals should turn up) for lyric grace and fanciful tenderness. The sparrow of Lesbia still pecks the rosy lips of his mistress, immortal as the eagle of Pindar. One profound imagination, one man, who with a more prosperous subject might have been a great poet, lifted Roman literature above its ordinary level of tasteful common-sense. The invocation of Venus, as the genetic force of nature, by Lucretius, seems to me the one sunburst of purely poetic inspiration which the Latin language can show. But this very force, without which neque fit latum neque amabile quicquam was wholly wanting in those poets of the post-classic period, through whom the literary influences of the past were transmitted to the romanized provincials. The works of Ausonius interest us as those of our own Dwights and Barlows do. The "Conquest of Canaan" and the "Columbiad" were Connecticut epics no doubt, but still were better than nothing in their day. If not literature, they were at least memories of literature, and such memories are not without effect in reproducing what they regret. The provincial writers of Latin devoted themselves with a dreary assiduity to the imitation of models which they decmed classical, but which were truly so only in the sense that they 
were the more decorously respectful of the dead form in proportion as the living spirit had more utterly gone out of it. It is, I suspect, to the traditions of this purely rhetorical influence, indirectly exercised, that we are to attribute the rapid passage of the new Provençal poetry from what must have been its original popular character to that highly artificial condition which precedes total extinction. It was the alienation of the written from the spoken language (always, perhaps, more or less malignly operative in giving Roman literature a cold-blooded turn as compared with Greek), which, ending at length in total dirorce, rendered Latin incapable of supplying the wants of new men and new ideas. The same thing, I am strongly inclined to think, was true of the language of the Troubadours. It had become literary, and so far dead. It is true that no language is erer so far gone in consumption as to be beyond the great-poet-cure. Undoulbtcdly a man of genius can out of his own superabundant vitality compel life into the most decrepit vocabulary. But it is by the infusion of his own blood, as it were, and not without a certain sacrifice of power. No such rescue came for the langue d'oc, which, it should seem, had performed its special function in the develppment of modern literature, and would have perished even without the Albigensian war. The position of the Gallo-Romins of the South, both ethical and geographical, precluded them from producing anything really great or eren original in literature, for that must have its root in a national life, and this they never had. After the Burgundian invasion their situation was in many respects analogous to our own after the Revolutionary War. They had been thoroughly romanized in language and culture, but the line of their historic continuity had been broken. The Roman road, which linked them with the only past they kncw, had been buried under the great barbarian 
land-slide. In like manner we, inheriting the language, the social usages, the literary and political traditions of Englishmen, were suddenly cut adrift from our historical anchorage. Very soon there arose a demand for a native literature, nay, it was even proposed that, as a first step toward it, we should adopt a lingo of our own to be called the Columbian or Hesperian. This, to be sure, was never accomplished, though our English cousins seem to hint sometimes that we have made very fair advances toward it; but if it could have been, our position would have been precisely that of the Provençals when they began to have a literature of their own. They had formed a language which, while it completed their orphanage from their imperial mother, continually recalled her, and kept alive their pride of linenge. Such reminiscences as they still retained of Latin culture were pedantic and rhetorical, and it was only natural that cut of these they should have elaborated a code of poetical jurisprudence with titles and subtitles applicable to every form of verse and tyrannous over every mode of sentiment. The result could not fail to be artificial and wearisome, except where some man with a truly lyrical genius could breathe life into the rigid formula and make it pliant to his more passionate feeling. The great service of the Provençals was that they kept in mind the fact that poetry was not merely an amusement, but an art, and long after their literary activity had ceased their influence reacted beneficially upon Europe through their Italian pupils. They are interesting as showing the tendency of the Romanic races to a scientific treatment of what, if it be not spontaneous, becomes a fashion and erelong an impertinence. Fauriel has endearored to prove that they were the first to treat the mediaval heroic legends epically, but the evidence is strongly against him. The testimony

- Faurie), Instoire de la Gaule Meridionale. Vol. I. passim. 
of Dante on this point is explicit,* and moreover not a single romance of chivalry has come down to us in a dialect of the pure Provencal.

The Trouvères, on the other hand, are apt to have something naive and vigorous about them, something that smacks of race and soil. Their very coarseness is almost better than the Troubadour delicacy, because it was not an affectation. The difference between the two schools is that between a culture pedantically transmitted and one which grows and gathers strength from natural causes. Indced, it is to the North of France and to the Trouvères that we are to look for the true origins of our modern literature. I do not mean in their epical poctry, though there is something refreshing in the mere fact of their choosing native heroes and legends as the subjects of their song. It was in their Fabliaux and Lais that, dealing with the realities of the life about them, they became original and delightful in spite of themselves. Their Chansons de Geste are fine specimens of fighting Christianity, highly inspiring for men like Peire de Bergerac, who sings

"Bel m'es can aug lo resso

Que fai l'ausbercs ab l'arso,

Li bruit e il crit e il masan

Que il corn e las trombas fan";

but who after reading them - even the best of them,

* Allegat ergo pro se lingua Oil quod propter sui faciliorem et delec. tabiliorem vulgaritatem, quicquid redactum sive inventum est ad rulgare prosaicum, suum est; videlicet biblia cum Trojanorum, Romanorumque gestibus compilata et Arturi regis ambages pulcherrime et quamplures alix historia ac doctrinx. That Dante by prosaicum did not mean prose, but a more inurtificial rerse, mumeros lege solutos, is clear. Cf. Wolf, Ueber die Lais, pp. 92 seq. and notes. It has not, I think, been remarkerl that Dante borrows his fuciliorem et delectabilio. rem from the plus diletable et comune of his master. Brunetto Latini.

† "My cars no sweeter music know 'Than hauberk's clank with saddlebow, The noise, the cries, the tumult blown From trumpet and from clarion." 
the Song of Roland - can remember much more than a cloud of battle-dust, through which the paladins loom dimly gigantic, and a strong verse flashes here and there like an angry sword? What are the Roman d'avantures, the cycle of Arthur and his knights, but a procession of armor and plumes, mere spectacle, not vision like their Grecian antitype, the Odyssey, whose pictures of life, whether domestic or heroic, are among the abiding consolations of the mind? An element of disproportion, of grotesqueness,* earmark of the barbarian, disturbs us, even when it does not disgust, in them all. Except the Roland, they all want adequate motive, and even in that we may well suspect a reminiscence of the Iliad. They are not without a kind of dignity, for manliness is always noble, and there are detached scenes that are striking, perhaps all the more so from their rarity, like the combat of Oliver and Fierabras, and the leave-taking of Parise la Duchesse. But in point of art they are far below even Firdusi, whose great poem is of precisely the same romantic type. The episode of Sohrab and Rustem as much surpasses the former of the passages just alluded to in largeness and energy of treatment, in the true epical quality, as the lament of Tehmine over her son does the latter of them in refined and natural pathos. In our revolt against psendo-classicism we must not let our admiration for the vigor and freshness which are the merit of this old poetry tempt us to forget that our direct literary inheritance comes to us from an ancestry who would never have got beyond the Age of Iron but for the models of graceful form and delicate workmanship which they found in the tombs of an earlier race. * I recall but one passage (from Jourdain de Blaivies) which in its simple movement of the heart can in any way be compared with Chancer. I translate it freely,

* Compare Floripar in Fierabras with Nausikäa, for example. 
merely changing the original assonance into rhyme. Erembor"c, to save the son of her liege-lord, has passedoff her own child for his, only stipulating that he shall pass the night before his death with her in the prison where she is confined by the usurper Fromond. The time is just as the dreaded dawn begins to break.

" 'Garnier, fair son,' the noble lady said,

'To save thy father's life must thou be dead;

And mine, alas, must be with sorrow spent,

Since thou must die, albeit so innocent!

Evening thou shalt not see that see'st the morn!

Woe worth the hour that I beheld thee born,

Whom nine long months within my side I bore!

Was never babe desired so much before.

Now summer will the pleasant days recall

When I shall take my stand upon the wall

And see the fair young gentlemen thy peers

That come and go, and, as beseems their years

Run at the quintain, strive to pierce the shield,

And in the tourney keep their sell or yield;

Then must my heart be tearswoln for thy sake

That ' $t$ will be marvel if it do not break.'

At morning, when the day began to peer,

Matins rang out from minsters far and near,

And the clerks sang full well with voices high.

'God,' said the dame, 'thou glorious in the sky,

These lingering nights were wont to tire me so!

And this, alas, how swift it hastes to go!

These clerks and cloistered folk, alas, in spite

So early sing to cheat me of my night! " "

The great advantages which the langue d'oil had over its sister dialect of the South of France were its wider distribution, and its representing the national and unitary tendencies of the people as opposed to those of provincial isolation. But the Trouveres had also this superiority, that they gave a roice to real and not mercly conventional emotions. In comparison with the Troubadonrs their sympathies were more human, and their expression more popular. While the tiresome ingenuity of the latter busied itself chiefly in the filigree of wire- 
drawn sentiment and supersubtilized conceit, the former took their subjects from the street and the market as well as from the château. In the one case language had become a mere material for clever elaboration; in the other, as always in live literature, it was a soil from which the roots of thought and feeling unconsciously drew the coloring of vivid expression. The writers of French, by the greater pliancy of their dialect and the simpler forms of their verse, had acquired an ease which was impossible in the more stately and sharply angled vocabulary of the South. Their octosyllabics have not seldom a careless facility not unworthy of Swift in his best mood. They had attained the highest skill and grace in narrative, as the lays of Marie de France and the Lai de l'Oiselet bear witness.* Above all, they had learned how to brighten the hitherto monotonous web of story with the gayer hues of fancy.

It is no improbable surmise that the sudden and surprising development of the more strictly epical poetry in the North of France, and especially its growing partiality for historical in preference to mythical subjects, were due to the Normans. The poetry of the Danes was much of it authentic history, or what was believed to be so; the heroes of their Sagas were real men, with wives and children, with relations public and domestic, on the common levels of life, and not mere creatures of imagination, who dwell apart like stars from the vulgar cares and interests of men. If we compare Havelok with the least idealized figures of Carlovingian or Arthurian romance, we shall have a keen sense of this difference. Manhood has taken the place of caste, and homeliness of exaggeration. Havelok says, -

"Godwot, I will with thee gang

For to learn some good to get;

* If internal evidence may be trusted, the Lci de l' Espine is not hers. 


\section{Swinken would I for my meat; \\ It is no shame for to swinken."}

This Dane, we sec, is of our own make and stature, a being much nearer our kindly sympathies than his compatriot Ogier, of whom we are told,

"Dix piès de lone avoit le chevalier."

But howerer large or small share we may allow to the Danes in changing the character of French poetry and supplanting the Romance with the Fabliau, there can be little doubt either of the kind or amount of influence which the Normans must have brought with them into England. I am not going to attempt a definition of the Anglo-Saxon element in English literature, for generalizations are apt to be as dangerous as they are tempting. But as a painter may draw a cloud so that we recognize its general truth, though the boundaries of real clouds never remain the same for two minutes together, so amid the changes of feature and complexion brought about by commingling of race, there still remains a certain cast of physiognomy which points back to some one ancestor of marked and peculiar character. It is toward this type that there is always a tendeney to revert, to borrow Mr. Darwin's phrase, and I think the general belief is not withont some adequate grounds which in France traces this predominant type to the Kelt, and in England to the Sixon. In old and stationary communities, where tradition has a chance to take root, and where several generations are present to the mind of each inhabitant, either by personal recollection or transmitted ancedote, everybody's peculiarities, whether of strength or wealkness, are explained and, as it were, justified upon some theory of hereditary bias. Such and such qualities he got from a grandfither on the spear or a great-uncle on the spindle side. This gift came in a right line from 
So-and-so; that failing came in by the dilution of the family blood with that of Such-a-one. In this way a certain allowance is made for every aberration from some assumed normal type, either in the way of reinforcement or defect, and that universal desire of the human mind to have everything accounted for - which makes the moon responsible for the whimsies of the weathercock is cheaply gratified. But as mankind in the aggregate is always wiser than any single man, because its experience is derived from a larger range of observation and experience, and because the springs that feed it drain a wider region both of time and space, there is commonly some greater or smaller share of truth in all popular prejudices. The meteorologists are begimning to agree with the old women that the moon is an accessary before the fact in our atmospheric fluctuations. Now, although to admit this notion of inherited good or ill to its fullest extent would be to abolish personal character, and with it all responsibility, to abdicate freewill, and to make every effort at self-direction futile, there is no inconsiderable alloy of truth in it, nevertheless. No man can look into the title-deeds of what may be called his personal estate, his faculties, his predilections, his failings, - whatever, in short, sets him apart as a capital I, without something like a shock of dread to find how much of him is held in mortmain by those who, though long ago mouldered away to dust, are yet fatally alive and active in him for good or ill. What is true of individual men is true also of races, and the prevailing belief in a nation as to the origin of certain of its characteristics has something of the same basis in facts of observation as the village estimate of the traits of particular families. Interdum vulgus rectum videt.

We are apt, it is true, to talk rather loosely ahout our Anglo-Saxon ancestors, and to attribute to them in a 
vague way all the pith of our institutions and the motive power of our progress. For my own part, I think there is such a thing as being too Anglo-Saxon, and the warp and woof of the English national character, though undoubtedly two elements mainly predominate in it, is quite too complex for us to pick out a strand here and there, and affirm that the body of the fabric is of this or that. Our present concern with the Saxons is chiefly a literary one ; but it leads to a study of general characteristics. What, then, so far as we can make it out, seems to be their leading mental feature? Plainly, understanding, common-sense, - a faculty which never carries its possessor very high in creative literature, though it may make him great as an acting and eren thinking man. Take Dr. Johnson as an instance. The Saxon, as it appears to me, has never shown any capacity for art, nay, commonly commits ugly blunders when he is tempted in that direction. He has made the best working institutions and the ugliest monuments among the children of men. He is wanting in taste, which is as much as to say that he has no true sense of proportion. His genius is his solidity, - an admirable foundation of national character. He is healthy, in no danger of liver-complaint, with digestive apparatus of amazing force and precision. He is the best farmer and best grazier among men, raises the biggest crops and the fattest cattle, and consumes proportionate quantities of both. He settles and sticks like a diluvial deposit on the warm, low-lying levels, physical and moral. He has a prodigious talent, to use our Yankee phrase, of stuying put. You camnot move him; he and rich earth have a natural sympathy of cohesion. (Not quarrelsome, but with indefitigalle durability of fight in him, sound of stomach, and not too refined in nervous texture, he is capable of indefinitely prolonged punishment, with a 
singularly obtuse sense of propriety in acknowledging himself beaten. Among all races perhaps none has shown so acute a sense of the side on which its bread is buttered, and so great a repugnance for having fine phrases take the place of the butyraceous principle. They invented the words "humbug," "cant," "shim," "gag," "soft-sodder," "flupdoddle," and other disenchanting formulas whereby the devil of falsehuod and unreality gets his effectual apage Sutana!

An imperturbable perception of the real relations of things is the Saxon's leading quality, - no sense whatever, or at best small, of the ideal in him. He has no notion that two and two ever make five, which is the problem the poet often has to solve. Understanding, that is, equilibrium of mind, intellectual good digestion, this, with unclogged biliary ducts, makes him montally and physically what we call a very fixed fact; but you shall not find a poet in a hundred thousand square miles, - in many prosperous centuries of such. But one element of incaleulable importance we have not mentioned. In this homely nature, the idea of God, and of a simple and direct relation between the All-Father and his children, is deeply rooted. There, above all, will he have honesty and simplicity; less than anything else will he have the sacramental wafer, - that beautiful emblem of our dependence on Him who giveth the daily bread; iess than anything will he have this smeared with that Barmecide butter of fair words. This is the lovely and noble side of his character. Indignation at this will make him forget crops and cattle; and this, after sc many centuries, will give him at last a poet in the monk of Eisleben, who shall cut deep on the memory of mankind that brief creed of conscience, - "Here arn I. God help me: I cannot otherwise." This, it seems to me, with dngged sense of justice, - both results of that 
equilibrium of thought which springs from clear-sighted understanding, - makes the beanty of the Saxon nature.

He believes in another world, and conceives of it without metaphysical sultleties as something very much after the pattern of this, but infinitely more desirable. Witness the vision of John Bunyan. Once beat it into him that his eternal well-being, as he calls it, depends on certain conditions, that only so will the balance in the ledger of eternity be in his favor, and the man who seemed wholly of this world will give all that he has, even his life, with a superb simplicity and scom of the theatric, fur a chance in the next. Hard to move, his very solidity of mature makes him terrible when once failly set agoing. He is the man of all others slow to admit the thought of revolution; but let him once admit it, he will carry it through and make it stick, - a secret hitherto undiscoverable by other races.

But poetry is not made out of the understanding; that is not the sort of block out of which you can carre wing-footed Mercuries. The question of common-sense is always, "What is it good for?" - a question which would abolish the rose and be answered triumphantly by the calluage. The dimger of the prosaic type of mind lies in the stolid sense of superiority which blinds it to ererything ideal, to the use of anything that does not serve the practical purposes of life. Do we not remember how the all-observing and all-fathoming Shakespeare has trpified this in Bottom the weaver? Surrounded by all the fairy creations of fancy, he sends one to fetch him the bag of a humble-bee, and can find no better employment for Mustard-seed than to help Cavalero Cobweb scratch his ass's head between the ears. When Titania, queen of that fair ideal world, offers him a feast of beauty, he says he has a good stomach to a pottle of hay! 
The Anglo-Saxons never had any real literature of their own. They produced monkish chronicles in bad Latin, and legends of saints in worse metre. Their earlier poetry is essentially Scandinavian. It was that gens inclytissima Northmannorum that imported the divine power of imagination, - that power which, mingled with the solid Saxon understanding, produced at last the miracle of Stratford. It was to this adventurous race, which found America before Columbus, which, for the sake of freedom of thought, could colonize inhospitable Iceland, which, as it were, typifying the very action of the imaginative faculty itself, identified itself always with what it conquered, that we owe whatever aquiline features there are in the national physiognomy of the English race. It was through the Normans that the English mind and fancy, hitherto provincial and uncouth, were first infused with the lightness, grace, and self-confidence of Romance literature. They seem to have opened a window to the southward in that solid and somewhat sombre insular character, and it was a painted window all aglow with the figures of tradition and poetry. The old Gothic volume, grim with legends of devilish temptation and satanic lore, they illuminated with the gay and brilliant inventions of a softer climate and more genial moods. Even the stories of Arthur and his knights, toward which the stern Dante himself relented so far as to call them gratissimas ambages, most delightful circumlocutions, though of British original, were first set free from the dungeon of a barbarous dialect by the French poets, and so brought back to England, and made popular there by the Normans.

Chaucer, to whom French must have been almost as truly a mother tongue as English, was familiar with all that had been done by Troubadour or Trouvère. In him we see the first result of the Norman yeast upon 
the home-baked Saxon loaf. The flour had been honest, the paste well kneaded, but the inspiring leaven was wanting till the Norman brought it over. Chaucer works still in the solid material of his race, but with what airy lightness has he not infused it? Without ceasing to be English, he has escaped from being insular. But he was something more than this ; he was a scholar, a thinker, and a critic. He had studied the Divina Commedica of Dante, he had read Petrarca and Boccaccio, and some of the Latin poets. He calls Dante the great poet of Italy, and Petrarch a learned clerk. It is plain that he knew very well the truer purpose of poetry, and had eren arrived at the higher wisdom of comprehending the aptitudes and limitations of his own genius. He saw clearly and felt keenly what were the faults and what the wants of the prevailing literature of his country. In the "Nonls"s Tile" he slyly satirizes the long-winded morality of (iower, as his prose antitype, Fielding, was to satirize the prolix sentimentality of Richardson. In the rhyme of Sir Thopas he gives the comp) de grace to the romanees of Chivalry, and in bis own choice of a subject he heralds that new world in which the actual and the popular were to supplant the fantastic and the heroic.

Before Chancer, modern Europe had given birth to one great poet, Dante; and contemporary with him was one supremely elegant one, Petrarch. Dante died only seven years before Chancer was born, and, so far as culture is derired from books, the moral and intellectual influenees they had been subjected to, the speculative stimulus that may have given an impulse to their minds, - there could have been no essential difference between them. Iet there are certain points of resemblance and of contrast, and those not entirely fanciful, which seem to me of considerable interest. Both 
were of mixed race, Dante certainily, Chancer presumably so. Dante seems to have inherited on the T'entonic side the strong moral sense, the almost nervous irritability of conscience, and the tendency to mysticism which made him the first of Christian poets, - first in point of time and first in point of greatness. From the uther side he seems to have received almost in overplus a feeling of order and proportion, sometimes wellnigh hardening into mathematical precision and formalism, - a tendency which at last brought the poetry of the Romanic races to a dead-lock of artifice and decorum. Chancer, on the other hand, drew from the South a certain airiness of sentiment and expression, a felicity of phrase, and an elegance of turn hitherto unprecedented and hardly yet matched in our literature, but all the while kept firm hold of his native soundness of understanding, and that genial humor which secms to be the proper element of worldly wisdom. With Dante, life represented the passage of the soul from a state of nature to a state of grace; and there would have been almost an eren chance whether (as Burns says) the Divina Commedia had turned out a song or a sermon, but for the wonderful genius of its author, which has compelled the sermon to sing and the song to preach, whether they would or no. With Chaucer, life is a pilgrimage, but only that his eye may be delighted with the varieties of costume and character. There are grood morals to be found in Chaucer, but they are always incidental. With Dante the main question is the saving of the soul, with Chaucer it is the conduct of life. The distance between them is almost that hetween holiness and prudence. Dante applies himself to the realities and Chaucer to the scenery of life, and the former is consequently the more universal poet, as the latter is the more truly national ove. Dante represents the 
justive of God, and Chaucer his loring-kindness. If there is anything that may properly be called satire in the one, it is like a blast of the divine wrath, before which the wretches cower and tremble, which rends away their cloaks of hypocrisy and their masks of worldly propriety, and leaves them shivering in the cruel nakedness of their shame. The satire of the other is genial with the broad sunshine of humor, into which the victims walk forth with a delightful unconcern, laying aside of themselves the disguises that seem to make them uncomfortably warm, till they have made a thorough betrayal of themselves so unconsciously that we almost pity while we langh. Dante shows us the punishment of sins against God and one's neighbor, in order that we may shum them, and so escape the doom that awaits them in the other world. Chancer exposes the cheats of the transmuter of metals, of the begging friars, and of the pedlers of indulgences, in order that we may be on our guard against them in this world. If we are to judge of what is national only by the highest and most characteristic types, surely we cammot fail to see in Chancer the true forerumner and prototype of Shakespeare, who, with an imagination of far deeper grasp, a far wider reach of thought, yet took the same delight in the pageantry of the actual world, and whose moral is the moral of worldly wistom only heightened to the level of his wide-riewing mind, and made typical by the dramatic energy of his plastic nature.

Tet if Claneer had little of that organic force of life which so inspires the poem of Dante that, as he himself sarys of the heavens, part answers to part with mutual interchange of light, he had a structural faculty which distinguishes him from all other English poets, his contemporaries, and which indeed is the primary distinction of poets properly so called. There is, to be sure, only 
one other English writer coeval with himself who deserves in any way to be compared with him, and that rather for contrast than for likeness.

With the single exception of Langland, the English pocts, his contemporaries, were little else than bad versifiers of legends classic or mediæval, as happened, without selection and without art. Chaucer is the first who broke away from the dreary traditional style, and gave not merely stories, but lively pictures of real life as the ever-renewed substance of poetry. He was a reformer, too, not only in literature, but in morals. But as in the former his exquisite tact saved him from all eccentricity, so in the latter the pervading sweetness of his nature could never be betrayed into harshness and invective. He seems incapable of indignation. $\mathrm{He}$ mused good-naturedly over the vices and follies of men, and, never forgetting that he was fashioned of the same clay, is rather apt to pity than condemn. There is no touch of cynicism in all he wrote. Dante's brush seems sometimes to have been smeared with the burning pitch of his own fiery lake. Chaucer's pencil is dipped in the cheerful color-box of the old illuminators, and he has their patient delicacy of touch, with a freedom far beyond their somewhat mechanic brilliancy.

English narrative poetry, as Chaucer found it, though it had not altogether escaped from the primal curse of long-windedness so painfully characteristic of its prototype, the French Romance of Chivalry, had certainly shorm a feeling for the picturesque, a sense of color, a directness of phrase, and a simplicity of treatment which give it graces of its own and a turn peculiar to itself. In the casy knack of story-telling, the popular minstrels cannot compare with Marie de France. The lightsomeness of fancy, that leaves a touch of sunshine and is gone, is painfully missed in them all. Their incidents 
enter dispersedly, as the old stage directions used to say, and they have not learned the art of concentrating their force on the key-point of their hearer's' interest. They neither get fairly hold of their subject, nor, what is more important, does it get hold of them. But they sometimes yield to an instinctive hint of leaving-off' at the right moment, and in their happy negligence achieve an effect only to be matched by the highest successes of art.

"That lady heard his mourning all

Right under her chamber wall,

In her oriel where she was,

Closëd well with royal glass;

Fulfilled it was with imagery

Every window, by and by;

On each side had there a gin

Sperred with many a divers pin;

Anon that lady fair and free

Undid a pin of ivory

And wide the window she open set,

The sun shone in at her closet."

It is true the old rhymer relapses a little into the habitual drone of his class, and shows half a mind to bolt into their common inventory style when he comes to his gins and pins, but he withstands the temptation manfully, and his sunshine fills our hearts with a gush as sudden as that which illumines the lady's oriel. Coleridge and Keats have each in his way felt the charm of this winsome picture, but have hardly equalled its hearty honesty, its economy of material, the supreme test of artistic skill. I admit that the phrase "had there a gin " is suspicious, and suggests a French original, but I remember nothing altogether so good in the romances from the other side of the Channel. One more passage occurs to me, almost incomparable in its simple straightforward force and choice of the right word.

"Sir Graysteel to his death thus thraws, He welters [wallows] and the grass updraws; 


\section{CHAUCER.}

A little while then lay he still, (Friends that saw him liked full ill,)

And bled into his armor bright."

The last line, for suggestive reticence, almost deserves to be put beside the famous

\section{"Quel giorno più non vi leggemmo avante"}

of the great master of laconic narration. In the same poem* the growing love of the lady, in its maidenliness of unconscious betrayal, is touched with a delicacy and tact as surprising as they are delightful. But such passages, which are the despair of poets who have to work in a langrage that has faded into diction, are exceptional. They are to be set down rather to good luck than to art. Even the stereotyped similes of these fortunate illiterates, like "weary as water in a weir," or "glad as grass is of the rain," are new, like nature, at the thousandth repetition. Perhaps our palled taste overvalues the wild flavor of these wayside treasure-troves. 'They are woodstrawberries, prized in proportion as we must turn over more leaves ere we find one. This popular literature is of value in helping us toward a juster estimate of Chaucer by showing what the mere language was capable of, and that all it wanted was a poet to put it through its paces. For though the poems I have quoted be, in their present form, later than he, they are, after all, but modernized versions of older copies, which they doubtless reproduce with substantial fidelity.

It is commonly assumed that Chancer did for English what Dante is supposed to have done for Italian and Luther for German, that he, in short, in some hitherto inexplicable way, created it. But this is to speak loosely and without book. Languages are never made in any

Sir Eger and Sir Grine in the Percy Folio. The passage quoted is from Ellis. 
such fashion, still less are they the achievement of any single man, however great his genius, however powerful his individuality. They shape themselves by laws as definite as those which guide and limit the growth of other living organisms. Dante, indeed, has told us that he chose to write in the tongue that might be learned of nurses and chafferers in the market. His practice shows that he knew perfectly well that poetry has needs which cannot be answered by the vehicle of vulgar commerce between man and man. What he instinctively felt was, that there was the living heart of all speech, without whose help the brain were powerless to send will, motion, meaning, to the limbs and extremities. But it is true that a langmage, as respects the uses of literature, is liable to a kind of syncope. No matter how complete its vocabulary may be, how thorough an outfit of inflections and case-endings it may have, it is a mere dead body without a soul till some man of genius set its arrested pulses once more athrob, and show what wealth of sweetness, scom, persuasion, and passion lay there awaiting its liberator. In this sense it is hardly too much to say that Chancer, like Dante, found his native tongue a dialect and left it a language. But it was not what he did with deliberate purpose of reform, it was his kindly and plastic genius that wrought this magic of renewal and inspiration. It was not the new words he introdueed,* Jut his way of using the old ones, that surprised them into grace, ease, and dignity in their own despite. In order to feel fully how much he achieved, let any one subject himself to a penitential course of reading in his contemporary, Gower, who worked in a material to all intents and purposes the same, or listen for a moment to the barbarous jangle which Lydgate and Occleve contrive to draw from the instrument their master had tuned

* I think he tried one now and then, like " eyen columbine." 
so deftly. Gower has positively raised tediousness to the precision of science, he has made dulness an heirloom for the students of our literary history. As you slip to and fro on the frozen levels of his verse, which give no foothold to the unind, as your nervous ear awaits the inevitable recurrence of his rhyme, regularly pertinacious as the tick of an cight-day clock and reminding you of Wordsworth's

"Once more the ass did lengthen out

The hard, dry, seesaw of his horrible bray,"

you lenrn to dread, almost to respect, the powers of this indefatigable man. $\mathrm{He}$ is the undertaker of the fair medirval legend, and his style has the hateful gloss, the secmingly umnatural length, of a coffin. Love, beauty, passion, nature, art, life, the natural and theological virtues, - there is nothing beyond his porrer to disenchant, nothing out of which the tremendous hydraulic press of his allegory (or whatever it is, for I am not sure if it be not something eren worse) will not squeeze all feeling and freshness and leare it a juicoless pulp. It matters not where you try him, whether his story be Christian or pagan, borrowed from history or fable, you cannot escape him. Dip in at the middle or the end, dodge back to the beginning, the patient old man is there to take you by the button and go on with his imperturbable narrative. You may have left off with Clytemnestra, and you begin again with Samson; it makes no odds, for you cannot tell one from tother. His tediousness is omnipresent, and like Dogberry he could find in his heart to bestow it all (and more if he had it) on your worship. The word lengthy has been charged to our American account, but it must have been invented by the first reader of Gower's works, the only inspiration of which they were ever capable. Our literature had to lie by and recruit for more than four centuries ere it could 
give us an equal vacuity in Tupper, so persistent a uniformity of commonplace in the "Recreations of a Country Parson." Let us be thankful that the industrious Gower never found time for recreation!

But a fitirer as well as more instructive comparison lies between Chaucer and the author of "Piers Ploughman." Langland has as much tenderness, as much interest in the varied picture of life, as hearty a contempt for hypocrisy, and almost an equal sense of fun. He has the same easy abundance of matter. But what a difference! It is the difference between the poet and the man of poetic temperament. The abundance of the one is a continual fulness within the fixed limits of good taste; that of the other is squandered in orerflow. The one can be profuse on occasion; the other is diffuse whether he will or no. The one is full of talk; the other is garrulous. What in one is the refined bonhomie of a man of the world, is a rustic shrewdness in the other. Both are kindly in their satire, and have not (like too many reformers) that vindictive love of virtue which spreads the stool of repentance with thistle-burrs before they invite the erring to seat themselves therein. But what in "Piers Ploughman" is sly fum, has the breadth and depth of humor in Chancer; and it is plain that while the former was taken up by his moral purpose, the main interest of the latter turned to perfecting the form of his work. In short, Chancer had that fine literary scnse which is as rare as genius, and, united with it, as it was in him, assures an immortality of fame. It is not merely what he has to say, but eren more the agreeable way he has of saying it, that captirates our attention and gives him an assured place in literature. Above all, it is not in detached passages that his charm lies, but in the entirety of expression and the cumulative effect of many particulars working toward a common end. Now though ex ungue leonem be 
a good rule in comparative anatomy, its application, except in a very limited way, in criticism is sure to mislead; for we should always bear in mind that the really great writer is great in the mass, and is to be tested less by his cleverness in the elaboration of parts than by thri reach of mind which is incapable of random effort, w'inich selects, arranges, combines, rejects, denies itscli the cheap triumph of immediate effects, becsuse it is absorbed by the controlling charm of projortion and unity. A careless good-luck of phrase is ảelightful ; but criticism cleaves to the teleological argument, and distinguishes the creative intellect, lot so much by any happiness of natural endowment as by the marks of design. It is true that one may sometimes discover by a single verse whether an author have imagination, or may make a shrewd guess whether he have style or no, just as by a few spoken words you may judge of a man's accent; but the true artist in language is never spotty, and needs no guide-boards of admiring italics, a critical method introduced by Leigh Hunt, whose feminine temperament gave him acute perceptions at the expense of judgment. This is the Bocotian method, which offers us a brick as a sample of the house, forgetting that it is not the goodness of the separate bricks, but the way in which they are put together, that brings them within the province of art, and makes the difference between a heap and a house. A great writer does not reveal himself here and there, but everywhere. Langland's verse runs mostly like a brook, with a beguiling and wellnigh slumberons prattle, but he, more often than any writer of his class, flashes into salient lines, gets inside our guard with the home-thrust of a forthright word, and he gains if taken piecemeal. His imagery is naturally and vividly picturesque, as where he says of Old Age, - 
"Eld the hoar

That was in the vauntward,

And bare the banner before death," -

.nnd he softens to a sweetness of sympathy beyond Chaucer risen he speaks of the poor or tells us that Mercy is "sib of ali sinful"; but to compare "Piers Ploughman" with the "Canicrbury Tales" is to compare sermon with song.

Let us put a bit of Laugi.nd's satire beside one of Chaucer's. Some people in searh of Truth meet a pilgrim and ask him whence he comes. 'He gives a long list of holy places, appealing for proof to the rulies on his hat :-

"'I have walked full wide in wet and in dry

And souglit saints for my soul's health.'

'Know'st thou ever a relic that is called Truth?

Couldst thou show us the way where that wight dwelleth?'

'Nay, so God help me,' said the man then,

'I saw never palmer with staff' nor with scrip

Ask after him ever till now in this place.' "

This is a good hit, and the poet is satisfied; but, in what I am going to quote from Chaucer, ererything becomes picture, over which lies broad and warm the sunshine of humorous fancy.

"In oldë dayës of the King Artour

Of which that Britouns speken gret honour,

All was this lond fulfilled of fayerie:

The elf-queen with her joly compaignie

Dancëd ful oft in many a grenë mede:

This was the old opinion as I rede;

I speke of many hundrid yer ago:

But now can no man see none elvës mo,

For now the gretë charite and prayëres

Of lymytours and other holy freres

That sechen every lond and every streem,

As thick as motis in the sonnëbeam,

Blessyng halles, chambres, kichenës, and boures,

Citees and burghës, castels hihe and toures,

Thorpës and bernes, shepnes and dayeries,

This makith that ther ben no fayeries.

For ther as wont to wakken was an elf 
There walkith none but the lymytour himself,

In undermelës and in morwenynges,

And sayth his matyns and his holy thinges,

As he goth in his lymytatioun.

Wommen may now go saufly up and doun;

In every bush or under every tre

There is none other incubus but he,

And he ne wol doon hem no dishonóur."

How cumningly the contrast is suggested here between the Elf-queen's jolly company and the unsocial limiters, thick as motes in the sumbeam, yet each walking by himself! And with what an air of immocent unconsciousness is the deadly thrust of the last verse given, with its contemptuous emphasis on the he that seems so well-meaning! Even Shakespeare, who seems to come in after everybody has done his best with a "Let me take hold a minute and show you how to do it," could not have bettered this.

"Piers Ploughman" is the best cxample I know of what is called popular poetry, - of compositions, that is, which contain all the simpler elements of poctry, but still in solution, not erystallized around any thread of artistic purpose. In it appears at her best the Anglo-Saxon Mruse, a first cousin of Poor Richard, full of proverbial wisdom, who always brings her knitting in her pocket, and seems most at home in the chimney-corner. It is genial; it plants itself firmly on human nature with its rights and wrongs; it has a surly honesty, prefers the downright to the gracious, and conceives of speech as a tool rather than a musical instrument. If we should seek for a single word that would define it most precisely, we should not choose simplicity, but homeliness. There is more or less of this in all carly poetry, to be sure ; but I think it especially proper to English poets, and to the most English among them, like Cowper, Crabbe, and one is tempted to add Wordsworth, - where he forgets Coleridge's private lectures. In reading such poets as Lang- 
land, also, we are not to forget a certain charm of distance in the very language they use, making it unhackneyed without being alien. As it is the chief function of the poet to make the familiar novel, these fortunate early risers of literature, who gather phrases with the dew still on them, have their poetry done for them, as it were, by their vocabulary. But in Chaucer, as in all great poets, the language gets its charm from him. The force and sweetness of his genius kneaded more kindly together the Latin and Teutonic elements of our mother tongue, and made something better than either. The necessity of writing poetry, and not mere verse, made him a reformer whether he would or no ; and the instinct of his finer ear was a guide such as none before him or contemporary with him, nor indeed any that came after him, till spenser, could command. (Gower had no notion of the uses of rhyme except as a kind of crease at the end of every eighth syllable, where the verse was to be folded over again into another layer. He says, for example,

"This maiden Canacee was hight, Both in the day and elie by night,"

as if people commonly changed their names at dark. And he could not even contrive to say this without the clumsy pleonasm of both and elie. Chaucer was put to no such shifts of piecing out his metre with loose-woven bits of baser stuff. He himself says, in the "Man of Law's Tale," -

"Me lists not of the chaff nor of the straw

To make so long a tale as of the corn."

One of the world's three or four great story-tellers, he was also one of the best rersifiers that ever made English trip and sing with a gayety that seems careless, but where every foot beats time to the tune of the thought. By the skilful arrangement of his pauses he evaded the 
monotony of the couplet, and gave to the rhymed pentameter, which he made our heroic measure, something of the architectural repose of blank verse. He found our language lumpish, stiff, unwilling, too apt to speak Saxonly in grouty monosyllables; he left it enriched with the longer measure of the Italian and Provençal poets. He reconciled, in the harmony of his verse, the English bluntness with the dignity and elegance of the less homely Southern speech. Though he did not and could not create our language (for he who writes to be read does not write for linguisters), yet it is true that he first made it easy, and to that extent modern, so that Spenser, two hundred years later, studied his method and called him master. He first wrote English ; and it was a feeling of this, I suspect, that made it fashionable in Elizabeth's day to " talk pure Chaucer." Already we find in his works verses that might pass without question in Milton or even Wordswrorth, so mainly unchanged have the language of poetry and the movement of verse remained from his day to our own.

"Thou Polymnia

On Pérnaso, that, with $*$ thy sisters glade, By Helicon, not far from Cirrea,

Singest with voice memorial in the shade, Under the laurel which that may not fade."

"And downward from a hill under a bent There stood the temple of Mars omnipotent

Wrought all of burnëd steel, of which th' entrée

Was long and strait and ghastly for to see:

The northern light in at the doorës shone

For window in the wall ne was there none

Through which men mighten any light discerne;

The dore was all of adamant eterne."

And here are some lines that would not seem out of place in the "Paradise of Dainty Derises":-

"Hide, Absolom, thy giltë [gilded] tresses clear,

Esther lay thou thy meekness all adown.

* Commonly printed hath. 


\section{Make of your wifehood no comparison ;}

Hide ye your beauties Ysoude and Elaine, My lady cometh, that all this may distain."

When I remember Chaucer's malediction upon his scriv. encr, and consider that by far the larger proportion of his verses (allowing always for change of pronunciation) are perfectly accordant with our present accentual system, I cannot believe that he ever wrote an imperfect line. His ear would never have tolerated the verses of nine syllables, with a strong accent on the first, attributed to him by Mr. Skeate and Mr. Morris. Such verses seem to me simply impossible in the pentameter iambic as Chaucer wrote it. A great deal of misapprehension would be aroided in discussing English metres, if it were only understood that quantity in Latin and quantity in English mean very different things. Perhaps the best quantitative verses in our language (better even than Coleridge's) are to be found in Mother Goose, composed by nurses wholly by ear and beating time as they danced the baby on their knee. I suspect Chaucer and Shakespeare would be surprised into a smile by the learned arguments which supply their halting verses with every kind of excuse except that of being readable. When verses were written to be chanted, more license could be allowed, for the ear tolerates the widest deviations from habitual accent in words that are sung. Segnius irritant demissa per auren. To some extent the same thing is true of anapestic and other tripping measures, but we cannot admit it in marching tunes like those of Chancer. He wrote for the eye more than for the voice, as poets had begun to do long hefore.* Some

* Froissart's description of the book of traités amoureux et de moralité, which he had had engrossed for presentation to Richard iI. in 1394 , is enough to bring tears to the eyes of a modern author. "Et lui plut très grandement; et plaire bien lui devoit car il était enluminé 
loose talk of Colcridge, loose in spite of its affectation of scientific precision, about "retardations" and the like, has misled many honest persons into believing that they can make good rerse out of bad prose. Coleridge himself, from natural fineness of ear, was the best metrist among modern English poets, and, read with proper allowances, his remarks upon versification are always instructive to whoever is not rhythm-deaf. But one has no patience with the dyspondruses, the pron primuses, and what not, with which he darkens verses that are to be explained only by the contemporary habits of pronumciation. Till after the time of Shakespeare we must always bear in mind that it is not a language of books but of living speech that we have to deal with. Of this language Coleridge had little knowledge, except what could be acquired through the ends of his fingers as they lazily turned the leares of his haphazard reading. If his eye was caught by a single passage that gave him a chance to theorize he did not look farther. Speaking of Massinger, for example, he says, "When a speech is interrupted, or one of the characters speaks aside, the last syllable of the former speech and first of the succeeding Massinger counts for one, because both are supposed to be spoken at the same moment.

'And felt the sweetness of' $t$

'How her mouth runs over.'"

Now fifty instances may be cited from Massinger which écrit et historié et couvert de vermeil velours à dis cloux d'argent dorés d'or, et roses d'or au milieu, et à deux grands fremaulx dorés et richement ouvrés au milien de rosiers d'or." "Inw lovingly he lingers over it, hooking it together with et after et! But two centuries earlier, while the jongleurs were stil' in full song, poems were also read aloud.

"Pur remembrer des ancessours

Les faits et les dits et les mours,

Deit l'en les livres et les gestes

Et les estoires lire a festes." - Roman du Rou.

But Chaucer wrote for the private reading of the closet. 
tell against this fanciful notion, for one that seems, and only seems, in its favor. Any one tolerably familiar with the dramatists knows that in the passage quoted by Coleridge, the how being emphatic, "how her" was pronounced how'r. He tells us that "Massinger is foud of the anaprst in the first and third foot, as :-

'Tŏ yoŭr müre | thăn mās/cŭlinĕ rēa/sŏn thāt | cŏmmānds 'ĕm ||.' Likewise of the second pæon ( $\smile \smile \smile)$ in the first foot, followed by four trochees (- $)$, as : -

'Sǒ grēēdǔly̆ | lōng fơr, | knōw theǐr | tītǐll|ātiŏns.'"

In truth, he was no fonder of them than his brother dramatists who, like him, wrote for the voice by the ear. "To your" is still one syllable in ordinary speech, and "masculine" and "greedily" were and are dissyllables or trisyllables according to their place in the verse. Coleridge was making pedantry of a very simple matter. Yet he has said with perfect truth of Chancer's verse, "Let a few plain rules be given for sounding the final è of syllables, and for expressing the terminations of such words as ocëan and natiön, dc., as dissyllables, - or let the syllables to be sounded in such cases be marked by a competent metrist. This simple expedient would, with a very few trifling exceptions, where the errors are inveterate, enable any one to feel the perfect smoothness and harmony of Chaucer's verse." But let us keep widely clear of Latin and Greek terms of prosody! It is also more important here than even with the dramatists of Shakespeare's time to remember that we have to do with a language canght more from the ear than from books. The best school for learning to understand Chaucer's elisions, compressions, slurrings-over and rumnings-together of syllables is to listen to the habitual speech of rustics with whom language is still plastic to meaning, and hurries or prolongs itself accordingly. Here is a contrac 
tion frequent in Chaucer, and still common in New Eng. land :-

"But me were lever than [lever' $n$ ] all this town, quod he."

Let one example suffice for many. To Coleridge's rules another should be added by a wise editor; and that is to restore the final $n$ in the infinitive and third person plural of verbs, and in such other cases as can be justified by the authority of Chaucer himself. Surely his ear could never have endured the sing-song of such verses as

or

"I couthe telle for a gowne-cloth,"

"Than ye to me schuld breke youre trouthe."

Chaucer's measure is so uniform (making due allowances) that words should be transposed or even omitted where the verse manifestly demands it, - and with copyists so long and dull of ear this is often the case. Sometimes they leave out a needful word:-

"But er [the] thunder stynte, there cometh rain,"

"When [that] we ben yflattered and ypraised,"

"Tak [ye] him for the greatest gentleman."

Sometimes they thrust in a word or words that hobble the verse :-

"She trowed he were yfel in [some] maladie,"

"Ye faren like a man [that] had lost his wit,"

"Then have I got of you the maystrie, quod she,"

( Then have I got the maystery, quod she,)

"And quod the jugë [also] thou must lose thy head."

Sometimes they give a wrong word identical in meaning :

"And therwithal he knew [couthë] mo proverbes."

Sometimes they change the true order of the words :-

"Therefore no woman of clerkës is [is of clerkës] praised "

"His felaw lo, here he stont [stont he] hool on live."

" He that covèteth is a porë wight

For he wold have that is not in his might;

But he that nought hath ne coveteth nought to have." 
Here the "but" of the third verse belongs at the head of the first, and we get rid of the anomaly of "coveteth" differently accented within two lines. Nearly all the seemingly unmetrical rerses may be righted in this way. I find a good example of this in the last stanza of "Troilus and Creseide." As it stands, we read, -

"Thou one, two, and three, eterne on live

That raignast aie in three, two and one."

It is plain that we should read "one and two" in the first verse, and "three and two" in the second. Remembering, then, that Chaucer was here translating Dante, I turned (after making the correction) to the original, and found as I expected

"Quell' uno $e$ due e tre che sempre vive

E regna sempre in tre $e$ due ed uno." (Par. xiv. 28, 29.)

In the stanza before this we have, -

"To thee and to the philosophicall strode,

To vouchsafe [vouchësafe] there need is, to correct" ;

and further on, -

"With all mine herte' of mercy ever I pray

And to the Lord aright thus I speake and say,"

where we must either strike out the second "I" or put it after "speake."

One often finds such changes made by ear justified by the readings in other texts, and we cannot but hope that the Chaucer Society will give us the means of at last settling upon a version which shall make the poems of one of the most fluent of metrists at least readable. Let any one compare the "Franklin's Tale" in the Aldine edition* with the text given by Wright, and he will find both sense and metre clear themselves up in a surprising way. A careful collation of texts, by the way, con-

* One of the very worst, be it said in passing. 
firms one's confidence in Tyrwhitt's good taste and thoroughness.

A writer in the "Proceedings of the Philological Society" has lately undertaken to prove that Chaucer did not sound the final or medial $e$, and throws us back on the old theory that he wrote "riding-rime," that is, verse to the eye and not the ear. This he attempts to do by showing that the Anglo-Norman poets themselves did not sound the $e$, or, at any rate, were not uniform in so doing. It should seem a sufficient answer to this merely to ask whence modern French poetry derived its rules of pronunciation so like those of Chaucer, so different from those of prose. But it is not enough to prove that some of the Anglo-Norman rhymers were bad versifiers. Let us look for examples in the works of the best poet among them all, Marie de France, with whose works Chaucer was certainly familiar. What was her practice? I open at random and find enough to overthrow the whole theory :-

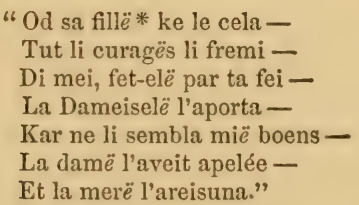

But how about the elision?

"Le pali' esgardë sur le lit -

Et ele' est devant li alée-

Bele' amië [cf. mië, above] ne'il me celez.

La dame' ad sa fille' amenée."

These are all on a single page $\dagger$, and there are some to

* Whence came, pray, the Elizabethan commandëment, chapëlain, surëty, and a score of nthers? Whence the Scottish bonny, and so many English words of Romance derivation ending in $y$ ?

$†$ Poésies de Marie de France, Tome I. p. 168. 
spare. How about the hiatus? On the same page I find, -

"Kar l'Ercëveskë $i$ estoit-

Pur eus beneistre' e enseiner."

What was the practice of Wace? Again I open at random.

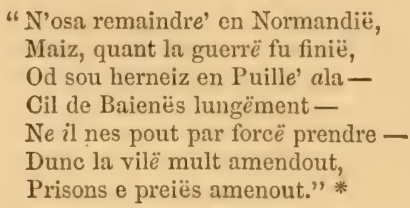

Again we have the sounded final $e$, the elision, and the hicutus. But what possible reason is there for supposing that Chaucer would go to obscure minstrels to learn the rules of French rersification? Nay, why are we to suppose that he followed them at all? In his case as in theirs, as in that of the Italians, with the works of whose two greater poets he was familiar, it was the language itself and the usages of pronunciation that guided the poet, and not arbitrary laws laid down by a synod of versemakers. Chancer's verse differs from that of Gower and Lydgate precisely as the verse of Spenser differs from that of Gascoigne, and for the same reason, - that he was a great poet, to whom measure was a natural vehicle. But admitting that he must have formed his style on the French poets, would he not have gone for lessons to the most famous and popular among them, the authors of the "Roman de la Rose"? Wherever you open that poem, you find Guillaume de Lorris and Jean de Meung following precisely the same method, - a method not in the least arbitrary, but inherent in tho material which they wrought. The $e$ sounded or ab. sorbed under the same conditions, the same slurring of

* Le Roman de la Rose, Tome II. p. 390. 
diphthongs, the same occasional hiatus, the same compression of several vowels into one sound where they immediately follow each other. Shakespeare and Milton would supply examples enough of all these practices that seem so incredible to those who write about versification without sufficient fineness of sense to feel the difference between Ben Jonson's blank verse and Marlow's. Some men are verse-deaf as others are color-blind, - Messrs. Malone and Guest, for example.

I try Rutebeuf in the same haphazard way, and chance brings me upon his "Pharisian." This poem is in stanzas, the verses of the first of which have all of them masculine rhymes, those of the second feminine ones, and so on in such continual alternation to the end, as to show that it was done with intention to avoid monotony. Of feminine rhymes we find ypocrisië, famë, justicë, mesurë, yglisë. But did Rutebeuf mean so to pronounce them? I open again at the poem of the Secrestain, which is written in regular octosyllabics, and read, -

"Envië fet homë tuer,

Et si fait bonnë remuer -

Envië greve', envië blecë,

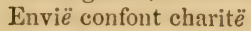

Envie' ocist humilitë, -

Estoit en ce paīs en vië

Sanz orgueil ere' et sanz envië-

La glorieusë, damë, chierë." $*$

Froissart was Chaucer's contemporary. What was his usage?

" J'avoië fait en ce voiaigë

Et je li di, "MIa damë s'ai-je

Pour vous ëu maint souvenir';

Mais je ne sui pas bien hardis

De vous remonstrer, damë chierë,

Par quel art ne par quel manierë,

J'ai ëu ce comencëment

De l'amourous atouchëment.' "

* Rutebeuf, Tome I. pp. 203 seqq. 304 seqq.

12 * 
If we try Philippe Mouskes, a mechinical rhymer, if ever there was one, and therefore the surer not to let go the leading-string's of rule, the result is the same.

But Chaucer, it is argued, was not uniform in his practice. Would this be likely? Certainly not with those terminations (like courtesië) which are questioned, and in diphthongs generally. Dante took precisely the same liberties.
"Facea le stelle a noi parer pii radi,"
"Nè fu per fantasia giammai compreso"
"Poi piovve dentro all 'alta fantasia,"
"Solea valor e cortesia trovarsi,"
"Che ne 'nvogliava amor e cortesia."

Here we have funtasì and fantasiä, cortesì and cortesiä. Even Pope has promiscuous, obsequious, as trisyllables, individual as a quadrisyllable, and words like tapestry, opera, indifferently as trochees or dactyls according to their place in the verse. Domne even goes so far as to make Cain a monosyllable and dissyllable in the same verse :-

"Sister and wife to Cain, Caïn that first did plough."

The cosural pause (a purely imaginary thing in accentual metres) may be made to balance a line like this of Donne's,

"Are they not like / singers at doors for meat,"

but we defy any one by any trick of voice to make it supply a missing syllable in what is called our heroic measure, so mainly used by Chaucer.

Enongh and far more than enough on a question about which it is as hard to be patient as about the authorship of Shakespeare's plays. It is easy to find all manner of bad metres among these versifiers, and plenty of inconsistencies, many or most of them the fault of careless or ignorant transcribers, but whoever has read 
them thoroughly, and with enough philological knowledge of cognate langmages to guide him, is sure that they at least aimed at regularity, precisely as he is convineed that Raynouard's rule about singular and plural terminations has plenty of evidence to sustain it, despite the numerous exceptions. To show what a bad versifier could make out of the same language that Chancer used, I copy one stanza from a contemporary poem.

"When Phebus fresh was in chare resplendent, In the moneth of May erly in a morning,

I hard two lovers profer this argument

In the yeere of our Lord a M. by rekening,

CCCXL. and VIII. yeere following.

$\mathrm{O}$ potent princesse conserve true lovers all

And grant them thy region and blisse celestial." *

Here is riding-rhyme, and on a very hard horse too! Can any one be insensible to the difference between such stuff as this and the measure of Chancer? Is it possible that with him the one halting verse should be the rule, and the twenty musical ones the exception? Let us take heed to his own words :-

"And, for there is so great diversite

In English, and in writing of our tong, So pray I God † that none miswritë the $\mathrm{Ne}$ the mismetre for defaut of tong, And redde whereso thou be or ellës song That thou be understood God I beseech."

Yet more. Boccaccio's ottciva rima is almost as regular as that of Tasso. Was Chaucer unconscious of this? It will be worth while to compare a stanza of the original with one of the translation.

"Era cortese Ettore di natura

Però vedendo di costei il gran pianto,

Ch 'era piu bella ch 'altra creatura,

Con pio parlare confortolla alquanto,

* From the "Craft of Lovers," attributed by Ritson to Lydgate, but too bad even for him.

$\dagger$ Here the received texts give "So pray I to God." Cf. "But Reason said him." 'T. \& C. 
Dicendo, lascia con la ria ventura

Tuo padre andar che tulti ha offeso tanto,

$\mathrm{E}$ tu, sicura e lieta, senza noia,

Mentre t 'aggrada, con noi resta in Troia." *

"Now was this Hector pitous of naturë,

And saw that she was sorrowful begon

And that she was so faire a creaturë,

Of his goodnesse he gladed her anon

And said [saidë] let your father's treason gon

Forth with mischance, and ye yourself in joy

Dwelleth with us while [that] you list in Troy."

If the Italian were read with the same ignorance that has wreaked itself on Chaucer, the riding-rhyme would be on its high horse in almost every line of Boccaccio's stanza. The same might be said of many a verse in Donne's satires. Spenser in his eclogues for February, May, and September evidently took it for granted that he had caught the measure of Chaucer, and it would be rather amusing; as well as instructive, to hear the maintainers of the hop-skip-and-jump theory of rersification attempt to make the elder poet's verses dance to the tu ie for which one of our greatest metrists (in his philological deafness) supposed their feet to be trained.

I will give one more example of Chaucer's verse, again making my selection from one of his less mature worizs. He is speaking of Tarquin :-

"And ay the morë he was in despair The more he coveted and thought her fair;

His blinde lust-was all his coveting.

On morrow when the bird began to sing

Unto the siege he cometh full privily

And by himself he walketh soberly

The imáge of her recording alway new :

Thus lay her hair, and thus fresh was her hue,

Thus sate, thus spake, thus span, this was her cheer,

'Thus fair she was, and this was her manére.

All this conceit his heart hath new ytake,

And as the sea, with tempest all toshake,

* Corrected from Kissner, p. 18. 
That after, when the storm is all ago,

Yet will the water quap a day or two,

Right so, though that her forme were absént,

The pleasance of her forme was presént."

And this passage leads me to say a few words of Chaucer as a descriptive poet; for I think it a great mistake to attribute to him any properly dramatic power, as some have done. Even Herr Hertzberg, in his remarkably intelligent essay, is led a little astray on this point by his enthusiasm. Chaucer is a great narrative poet; and, in this species of poetry, though the author's personality should never be obtruded, it yet unconsciously pervades the whole, and communicates an individual quality, - a kind of flavor of its own. This very quality, and it is one of the highest in its way and place, would be fatal to all dramatic force. The narrative poet is occupied with his characters as picture, with their grouping, even their costume, it may be, and he fecls for and with them instead of being they for the moment, as the dramatist must always be. The storyteller must possess the situation perfectly in all its details, while the imagination of the dramatist must be possessed and mastered by it. The latter puts before us the very passion or emotion itself in its utmost intensity ; the former gives them, not in their primary form, but in that derivative one which they have acquired by passing through his own mind and being modified by his reflection. The deepest pathos of the drama, like the quiet " no more but so?" with which Shakespeare tells us that Ophelia's heart is bursting, is sudden as a stab, while in narrative it is more or less suffused with pity, - a feeling capable of prolonged sustention. This presence of the anthor's own sympathy is noticeable in all Chaucer's pathetic passages, as, for instance, in the lamentation of Constance over her child in the "Man of 
Law's Tale." When he comes to the sorrow of his story, he secms to croon over his thoughts, to soothe them and dwell upon them with a kind of pleased compassion, as a child treats a wounded bird which he fears to grasp too tightly, and yet camnot make up his heart wholly to let go. It is true also of his humor that it pervades his comic tales like sumshine, and never dazzles the attention by a sudden flash. Sometimes he brings it in parcnthetically, and insinuates a sarcasm so slyly as almost to slip by without our notice, as where he satirizes provincialism by the cock

"Who knew by nature each ascensiön Of the equinoctial in his native town."

Sometimes he turns round upon himself and smiles at a trip he has made into fine writing:-

"Till that the brightë sun had lost his hue,

For th' orisont had reft the sun his light,

(This is as much to sayen as 'it was night.') "

Nay, sometimes it twinkles roguishly through his very tears, as in the

"' Why wouldest thou be dend,' these women cry,

"Thou haddest gold enough - and Emily? '"

that follows so close upon the profoundly tender despair of Arcite's farewell :-

"What is this world? What asken men to have?

Now with his love now in the coldë grave

Alone withouten any company!"

The powrer of diffusion without being diffuse would seem to be the highest merit of narration, giving it that easy flow which is so delightful. Chancer's descriptive style is remarkable for its lowness of tone, - for that combination of energy with simplicity which is among the rarest gifts in literature. Perluaps all is said in saying that he has style at all, for that consists mainly in the absence of undue emphasis and exaggeration, in the clear 
uniform pitch which penetrates our interest and retains it, where mere loudness would only disturb and irritate.

Not that Chaucer cannot be intense, too, on occasion; but it is with a quiet intensity of his own, that comes in as it were by accident.

"Upon a thickë palfrey, paper-white,

With saddle red embroidered with delight,

Sits Dido:

And she is fair as is the brightë morrow

That healeth sickë folk of nightës sorrow.

Upon a courser startling as the fire, Eneas sits."

Pandarus, looking at Troilus,

"Took up a light and found his countenance As for to look upon an old romance."

With Chaucer it is always the thing itself and not the description of it that is the main object. His picturesque bits are incidental to the story, glimpsed in passing; they never stop the way. His key is so low that his high lights are never obtrusive. His imitators, like Leigh Hunt, and Keats' in his "Endymion," missing the nice gradation with which the master toned everything down, become streaky. Hogarth, who reminds one of him in the variety and natural action of his figures, is like him also in the subdued brilliancy of his coloring. When Chaucer condenses, it is because his conception is vivid. He does not need to personify Revenge, for personification is but the subterfuge of unimaginative and professional poets; but he embodies the very passion itself in a verse that makes us glance over our shoulder as if we heard a stealthy tread behind us :-

"The smiler with the knife hid under the cloak." *

And yet how unlike is the operation of the imaginative faculty in him and Shakespeare! When the latter de-

- Compare this with the Mumbo-Jumbo Revenge in Collins's Ode. 
scribes, his epithets imply always an impression on the moral sense (so to speak) of the person who hears or sees. The sun "flatters the mountain-tops with sovereign eye"; the bending "weeds lacquey the dull stream"; the shadow of the falcon "coucheth the fowl below"; the smoke is "helpless"; when Tarquin enters the chamber of Lucrece "the threshold grates the door to have him heard." His outward sense is merely a window through which the metaphysical eye looks forth, and his mind passes over at once from the simple sensation to the complex meaning of it, - feels with the object instead of merely feeling it. His imagination is forever dramatizing. Chaucer gives only the direct impression made on the eye or ear. He was the first great poet who really loved outward nature as the source of conscious pleasurable emotion. The Troubadour hailed the return of spring; but with him it was a piece of empty ritualism. Chaueer took a true delight in the now green of the leaves and the return of singing birds, - a delight as simple as that of Robin Hood:-

"In summer when the shaws be sheen, And leaves be large and long,

It is full merry in fair forest

To hear the small birds' song."

He has nerer so much as heard of the "burthen and the mystery of all this unintelligible world." His flowers and trees and birds have never bothered themselves with Spinoza. He himself sings more like a bird than any other poet, because it never occurred to him, as to Goethe, that he ought to do so. He pours himself out in sincere joy and thankfulness. When we compare Spenser's imitations of him with the original passages, we fecl that the delight of the later poet was more in the expression than in the thing itself. Nature with him is only good to be transfigured by art. We walk among Chau- 
eer's sights and sounds; we listen to Spenser's musical reproduction of them. In the same way, the pleasure which Chaucer takes in telling his stories has in itself the effect of consummate skill, and makes us follow all the windings of his fancy with sympathetic interest. His best tales run on like one of our inland rivers, sometimes hastening a little and turning upon themselves in eddies that dimple without retarding the current; sometimes loitering smoothly, while here and there a quict thought, a tender feeling, a pleasant image, a golden-hearted verse, opens quietly as a water-lily, to float on the surface without breaking it into ripple. The vulgar intellectual palate hankers after the titillation of foaming phrase, and thinks nothing good for much that does not go off with a pop like a champagne cork. The mellow suavity of more precious vintages scems insipid: but the taste, in proportion as it refines, lcarns to appreciate the indefinable flavor, too subtile for analysis. A manner has prevailed of late in which every other word secms to be underscored as in a school-girl's letter. The poet seems intent on showing his sinew, as if the power of the slim $\Lambda$ pollo lay in the girth of his biceps. Force for the mere sake of force ends like Milo, caught and held mockingly fast by the recoil of the log he mudertook to rive. In the race of fame, there are a score capable of brilliant spurts for one who comes in winner after a steady pull with wind and muscle to spare. Chaucer never shows any signs of effort, and it is a main proof of his excellence that he can be so inadequately sampled by detached passages, - by single lines talien away from the connection in which they contribute to the general effect. He has that continuity of thought, that evenly prolonged power, and that delightful equanimity, which characterize the higher orders of mind. There is something in him of the disinterestedness that made the Greeks masters in art. His 
phrase is never importunate. His simplicity is that of elegance, not of poverty. The quiet unconcern with which he says his best things is peculiar to him among English poets, though Goldsmith, Addison, and Thackeray have approached it in prose. He prattles inadvertently away, and all the while, like the princess in the story, lets fall a pearl at every other word. It is such a piece of good luck to be natural! It is the good gift which the fairy godmother brings to her prime favorites in the cradle. If not genius, it is alone what makes genius amiable in the arts. If a man have it not, he will never find it, for when it is sought it is gone.

When Chancer describes anything, it is commonly by one of those simple and obvious epithets or qualities that are so easy to miss. Is it a woman? He tells us she is fresh; that she has glad eyes; that " every day her beauty newed"; that

"Methought all fellowship as naked Withouten her that I saw once, As a coróne without the stones."

Sometimes he describes amply by the merest hint, as where the Friar, before setting himself softly down, drives away the eat. We know without need of more words that he has chosen the snuggest corner. In some of his early poems he sometimes, it is true, falls into the catalogue style of his contemporaries; but after he had found his genius he never particularizes too much, - a process as deadly to all effect as an explanation to a pun. The first stanza of the "Clerk's Tale" gives us a landscape whose stately choice of objects shows a skill in composition worthy of Claude, the last artist who painted nature epically :-

"There is at the west endë of Itaile, Down at the foot of Vesulus the cold, A lusty plain abundant of vitaile, 
Where many a tower and town thou may'st behold

That founded were in time of fathers old,

And many another delítable sight;

And Sálucës this noble country hight."

The Pre-Raphaelite style of landscape entangles the eye among the obtrusive weeds and grass-blades of the foreground which, in looking at a real bit of scenery, we overlook; but what a sweep of vision is here! and what happy generalization in the sixth verse as the poet turns away to the business of his story! The whole is full of open air.

But it is in his characters, especially, that his manner is large and free; for he is painting history, though with the fidelity of portrait. He brings out strongly the essential traits, characteristic of the genus rather than of the individual. The Merchant who keeps so steady a countenance that

"There wist no wight that he was e'er in debt,"

the Sergeant at Law, "who seemëd busier than he was," the Doctor of Medicine, whose "study was but little on the Bible," - in all these cases it is the type and not the personage that fixes his attention. William Blake says truly, though he expresses his meaning somewhat clumsily, "the characters of Chaucer's Pilgrims are the characters which compose all ages and nations. Some of the names and titles are altered by time, but the characters remain forever unaltered, and consequently they are the physiognomies and lineaments of universal human life, beyond which Nature never steps. Names alter, things never alter. As Newton numbered the stars, and as Linnæus numbered the plants, so Chaucer numbered the classes of men." In his outside accessaries, it is true, he sometimes seems as minute as if he were illuminating a missal. Nothing escapes his sure eye for the picturesque, - the cut of the beard, the soil of armor on the buff 
jerkin, the rust on the sword, the expression of the eye. But in this he has an artistic purpose. It is here that he individualizes, and, while every touch harmonizes with and secms to complete the moral features of the chiracter, makes us feel that we are among living men, and not the abstracted images of men. Crabbe adds particular to particular, scattering rather than deepening the impression of reality, and making us feel as if every man were a species by himself; but Chatueer, never forgetting the essential sameness of human nature, makes it jossible, and even probable, that his motley characters should meet on a common footing, while he gives to cach the erpuression that belongs to him, the result of special circumstance or training. Indeed, the absence of any suggestion of caste camnot fail to strike any reader familiar with the literature on which he is supposed to have formed himself. No characters are at once so broadly human and so definitely outlined as his. Belonging, some of them, to extinct trpes, they continue contemporary and fimiliar forever. So wide is the difference hetween knowing a great many mon and that knowledge of human nature which comes of sympathetic insight and not of observation alone.

It is this power of sympathy which makes Chaucer's satire so kindly, - more so, one is tempted to say, than the panegyric of Pope. Intellectual satire gets its force from personal or moral antipathy, and measures offences by some rigid conrentional standard. Its mouth waters orer a galling word, and it lores to say Thou, pointing out its rictim to public scorn. Indignatio facit versus, it boasts, though they might as often be fathered on cnry or hatred. But imaginative satire, warmed through and throngh with the genial leaven of humor, smiles half sadly and nurmurs $W_{e}$. Chaucer either makes one kuave betray another, through a natural jealousy of 
competition, or else expose himself with a naïveté of good-humored cynicism which amuses rather than disgusts. In the former case the butt has a kind of claim on our sympathy; in the latter, it seems nothing strange if the sumny atmosphere which floods that road to Canterbury should tempt anybody to throw off one disguise after another without suspicion. With perfect tact, too, the Host is made the choragnes in this diverse company, and the coarse jollity of his temperament explains, if it does not exense, much that would otherwise seem out of keeping. Surely nobody need have any scruples with him.

Chaucer scems to me to have been one of the most purely original of poets, as much so in respect of the world that is about us as Dante in respect of that which is within us. There had been nothing like him before, there has been nothing since. He is original, not in the sense that he thinks and says what nobody ever thought and said before, and what nobody can ever think and say again, but because he is almays natural, because, if not always absolutely new, he is always delightfully fresh, because he sets before us the world as it honestly appeared to Geoffrey Chaucer, and not a world as it seemed proper to certain people that it ought to appear. He found that the poctry which had preceded him had been first the expression of individual feeling; then of class fecling as the vehicle of legend and history, and at last had wellnigh lost itself in chasing the mirage of allegory. Literature seemed to have passed through the natural stages which at regular intervals bring it to decline. Even the lyries of the jongleurs were all rum in one mould, and the Pastourelles of Northern France had become as artificial as the Pastorals of Pope. The Romances of chiralry had been made over into prese, and the Melusine of his contemporary Jehan d'Arras is 
the forlorn hope of the modern novel. Arrived thus far in their decrepitude, the monks endeavored to give them a religious and moral turn by allegorizing them. Their process reminds one of something Ulloa tells us of the fashion in which the Spaniards converted the Mexicans : "Here we found an old man in a cavern so extremely aged as it was wonderful, which could neither see nor go because he was so lame and crooked. 'The Father, Friar Raimund, said it were good (seeing he was so aged) to make him a Christian; whereupon we baptized him." The monks found the Romances in the same stage of senility, and gave them a saving sprinkle with the holy water of allegory. Perhaps they were only trying to turn the enemy's own weapons against himself, for it was the free-thinking "Romance of the Rose" that more than anything else had made allegory fashionable. Plutarch tells us that an allegory is to say one thing where another is meant, and this might have been needful for the personal security of Jean de Neung, as afterwards for that of his successor, Rabelais. But, except as a means of erading the fagot, the method has few recommendations. It reverses the true office of poetry by making the real unreal. It is imagination endeavoring to recommend itself to the understanding by means of cuts. If an author be in such deadly carnest, or if his imagination be of such creative vigor as to project real figures when it meant to cast only a shadow upon vapor; if the true spirit come, at once olsequions and terrible, when the conjurer has drawn his circle and gone through with his incantations merely to produce a proper frame of mind in his audience, as was the case with Dante, there is no longer any question of allegory as the word and thing are commonly understood. But with all secondary poets, as with Spenser for example, the allegory does not become of 
one substance with the poetry, but is a kind of carven frame for it, whose figures lose their meaning, as they cease to be contemporary. It was not a style that could have much attraction for a nature so sensitive to the actual, so observant of it, so interested by it as that of Chaucer. He seems to have tried his hand at all the forms in vogue, and to have arrived in his old age at the truth, essential to all really great poetry, that his own instincts were his safest guides, that there is nothing deeper in life than life itself, and that to conjure an allegorical significance into it was to lose sight of its real meaning. He of all men could not say one thing and mean another, unless by way of humorous contrast.

In thus turning frankly and gayly to the actual world, and drinking inspiration from sources open to all; in turning away from a colorless abstraction to the solid earth and to emotions common to every pulse; in discovering that to make the best of nature, and not to grope raguely after something better than nature, was the true office of Art ; in insisting on a definite purpose, on veracity, cheerfulness, and simplicity, Chaucer shows himself the true father and founder of what is characteristically English literature. He has a hatred of cant as hearty as Dr. Johnson's, though he has a slier way of showing it ; he has the placid common-sense of Franklin, the sweet, grave humor of Addison, the exquisite taste of Gray; but the whole texture of his mind, though its substance seem plain and grave, shows itself at every turn iridescent with poetic fecling like shot silk. Above all, he has an eye for character that seems to have caught at once not only its mental and physical features, but even its expression in variety of costume, - an eye, indeed, second only, if it should be called second in some respects, to that of Shakespeare.

I know of nothing that may be compared with the 
prologue to the "Canterbury Tales," and with that to the story of the "Chanon's Yeoman" before Chancer. Characters and portraits from real life had never been drawn with such discrimination, or with such variety, never with such bold precision of outline, and with such a lively sense of the picturesque. His Parson is still unmatched, though Dryden and Goldsmith have both tried their hands in emulation of him. And the humor also in its suavity, its perpetual presence and its shy unobtrusiveness, is something wholly new in literature. For anything that deserves to be called like it in English we must wait for Henry Fielding.

Chancer is the first great poet who has treated To-day as if it were as good as Yesterday, the first who hold up a mirror to contemporary life in its infinite variety of high and low, of humor and pathos. But he reflected life in its large sense as the life of men, from the knight to the ploughman, - the life of every day as it is made up of that curious compound of human nature with manners. The very form of the "Canterbury Tales" was imaginative. The garden of Boccaccio, the supper-party of Grazzini, and the royage of Giraldi make a good enough thread for their stories, but exclude all save equals and friends, exclude consequently human nature in its wider meaning. But by choosing a pilgrimage, Chaucer puts us on a plane where all men are equal, with souls to be saved, and with another world in riew that abolishes all distinctions. By this choice, and by making the Host of the Tabard always the central figure, he has happily united the two most familiar emblems of life, - the short journey and the inn. We find more and more as we study him that he rises quietly from the conventional to the universal, and may fairly take his place with Homer in virtue of the breadth of his humanity.

In spite of some external stains, which those who 
have studied the influence of manners will easily account for without imputing them to any moral depravity, wo feel that we can join the pure-minded Spenser in calling him "most sacred, happy spirit." If character may be divined from works, he was a good man, genial, sincere, hearty, temperate of mind, more wise, perhaps, for this world than the next, but thoroughly humane, and friendly with God and men. I know not how to sum up what we feel about him better than by saying (what would have pleased most one who was indifferent to fame) that we love him more even than we admire. We are sure that here was a true brother-man so kindly that, in his "House of Fame," after naming the great poets, he throws in a pleasant word for the oaten-pipes

"Of the little herd-grooms

That keepen beasts among the brooms."

No better inscription can be written on the first page of his works than that which he places over the gate in his "Assembly of Forwls," and which contrasts so sweetly with the stern lines of Dante from which they were imitated:-

"Through me men go into the blissful place

Of the heart's heal and deadly woundës' cure;

Through me men go unto the well of Grace,

Where green and lusty May doth ever endure;

This is the way to all good aventure;

Be glad, thou Reader, and thy sorrow offcast, All open am I, pass iu, and speed thee fast!" 


\section{LIBRARY OF OLD AUTHORS.*}

TANY of our older readers can remember the an1 I ticipation with which they looked for each suc. cessive volume of the late Dr. Young's excellent series of old English prose-writers, and the delight with which they carried it home, fresh from the press and the bindery in its appropriate livery of evergreen. To most of us it was our first introduction to the highest society of letters, and we still feel grateful to the departed scholar who gave us to share the conversation of such men as Latimer, More, Sidney, Taylor, Browne, Fuller, and Walton. What a sense of security in an old book which Time has criticised for us! What a precious feeling of seclusion in having a double wall of centuries between us and the heats and clamors of contemporary literature! How limpid seems the thought, how pure the old wine of seholarship that has been settling for so many generations in those silent erypts and Falernian amphorce of the Past! No other writers speak to us with the authority of those whose ordinary speceh was that of our translation of the Scriptures; to no modern is that frank unconsciousness possible which was natural to a period when yet reviews were not; and no later style breathes that comntry charm characteristic of days ere the metropolis had drawn all literary activity to itsclf, and the trampling feet of the multitude had banished the lark and the daisy from the fresh privacies of lan-

* London: John Russell Smith. 1856-64. 
guage. Truly, as compared with the present, these old voices seem to come from the morning fields and not the paved thoroughfares of thought.

Even the "Retrospective Review" continues to be good reading, in virtue of the antique aroma (for wine only acquires its bouquet by age) which pervades its pages. Its sixteen volumes are so many tickets of admission to the rast and devious vaults of the sixteenth and serenteenth centuries, through which we wander, tasting a thimbleful of rich Canary, honeyed Cyprus, or subacidulous Hock, from what dusty butt or keg our fancy chooses. The years during which this review was published were altogether the most fruitful in genuine appreciation of old English literature. Books were prized for their imaginative and not their antiquarian value by young writers who sate at the feet of Lamb and Coleridge. Rarities of style, of thought, of fancy, were sought, rather than the barren scarcities of typography. But another race of men seems to have sprung up, in whom the futile enthusiasm of the collector predominates, who substitute archrologic perversity for finenerved scholarship, and the worthless profusion of the curiosity-shop for the sifted exclusiveness of the cabinet of Art. They forget, in their fanaticism for antiquity, that the dust of never so many centuries is impotent to transform a curiosity into a gem, that only good books absorb mellowness of tone from age, and that a baptismal register which proves a patriarchal longevity (if existence be life) cannot make mediocrity anything but a bore, or garrulous commonplace entertaining. There are rolumes which have the old age of Plato, rich with gathering experience, meditation, and wisdom, which seem to have sucked color and ripeness from the genial autumns of all the select intelligences that have steeped them in the sunshine of their love and appreciation; - these quaint 
freaks of russet tell of Montaigne; these stripes of crimson fire, of Shakespenre; this sober gold, of Sir Thomas Browne; this purpling bloom, of Lamb; in such fruits we taste the legendary gardens of Alcinoüs and the orchards of Atlas; and there are rolumes again which can claim only the inglorious senility of Old Parr or older Jenkins, which have outlived their half-dozen of kings to be the prize of showmen and treasuries of the born-to-be-forgotten trifles of a hundred years ago.

We confess a bibliothecarian avarice that gives all books a value in our eyes; there is for us a recondite wisdom in the phrase, " $\Lambda$ book is a book"; from the time when we made the first eatalogue of our library, in which "Bible, large, 1 vol.," and "Bible, small, 1 vol.," asserted their alphabetic individuality and were the sole $B$ s in our little hive, we have had a weakness even for those checker-board rolumes that only fill up; we cannot breathe the thin air of that Pepysian self-denial, that Himalayan selectness, which, content with one bookcase, would have no tomes in it but porphlyyrogeniti, books of the bluest blood, making room for choicer new-comers by a continuous ostracism to the garret of present incumbents. There is to us a sacredness in a volume, however dull; we live over again the author's lonely labors and tremulous hopes; we see him, on his first appearance after parturition, "as well as could be expected," a nervous sympathy yet surviving between the late-severed umbilical cord and the wondrous offspring, doubtfully entering the Mermaid, or the Devil Tavern, or the Coffec-house of Will or Button, blushing under the eye of Ben or Dryden or Addison, as if they must needs know him for the author of the "Modest Enquiry into the Present State of Dramatique Poetry," or of the "Unities briefly considered by Philomusus," of which they have never heard and never will hear so much as 
the names; we sce the country-gentlemen (sole cause of its surviving to our day) who buy it as a book no gentloman's library can be complete without; we see the spendthrift heir, whose horses and hounds and Pharaonic troops of friends, drowned in a Red Sea of claret, bring it to the hammer, the tall octavo in tree-calf following the ancestral oaks of the park. Such a volume is sacred to us. But it must be the original foundling of the book-stall, the engraved blazon of some extinct baronetcy within its cover, its leaves enshrining memorialflowers of some passion which the churchyard smothered ere the Stuarts were yet discrowned, suggestive of the trail of laced ruffles, burnt here and there with ashes from the pipe of some dozing poet, its binding worn and weather-stained, that has felt the inquisitive finger, perhaps, of Malone, or thrilled to the touch of Lamb, doubtful between desire and the odd sixpence. When it comes to a question of reprinting; we are more choice. The new duodecimo is bald and bare, indeed, compared with its battered prototype that could draw us with a single hair of association.

It is not easy to divine the rule which has governed Mr. Smith in making the selections for his series. A choice of old authors should be a florileginm, and not a botanist's hortus siccus, to which grasses are as important as the single shy blossom of a summer. The old-maidenly genius of antiquarianism seems to have presided over the editing of the "Library." We should be inclined to surmise that the works to be reprinted had been commonly suggested by gentlemen with whom they were especial favorites, or who were ambitious that their own names should be signalized on the title-pages with the suffix of EDitor. The volumes already published are: Increase Mather's "Remarkable Providences"; the poems of Drummond of Hatrthornden; the "Vis- 
ions of Piers Ploughman;" the works in prose and verse of Sir Thomas Overbury; the "Hymus and Songs" and the "Hallelujah" of George Wither; the poems of Southwell ; Selden's "Table-Talk"; the "Enchiridion" of Quarles ; the dramatic works of Marston, Webster, and Lilly; Chapman's translation of Homer; Lovelace, and four rolumes of "Early English Poetry"! The rolume of Mather is curious and entertaining, and fit to stand on the same shelf with the "Magnalia" of his booksuffocated son. Cumningham's comparatively recent edition, we should think, might satisfy for a long time to come the demand for Drummond, whose chief value to posterity is as the Boswell of Ben Jonson. Sir Thomas Overbury's "Characters" are interesting illustrations of contemporary mamers, and a mine of footnotes to the works of better men, - but, with the exception of "The Fair and Happy Milkmaid," they are dull enough to have pleased James the First; his "Wife" is a cento of fir-fetched conceits, -- here a tomtit, and there a hen mistaken for a pheasant, like the contents of a cockney's game-bag, and his chief interest for us lies in his having been mixed up with an inexplicable tragedy and poisoned in the Tower, not without suspicion of royal complicity. The "Piers Ploughman" is a reprint, with very little improvement that we can discover, of Mrr. Wright's former edition. It would have been very well to have repullished the "Fair Virtue," and "Shepherd's Hunting" of George Wither, which contain all the true poetry he ever wrote; but we can imagrine nothing more dreary than the seven hundred pages of his "Hymms and Songs," whose only use, that we can conceive of, would he as penal reading for incoryigible poetasters. If a steady course of these did not bring them out of their nonsenses, nothing short of hanging would. Take this as a sample, hit on by open. ing at random :- 
" Rottenness my bones possest;

Trembling fear possessèd me;

I that troublous day might rest:

For, when his approaches be

Onward to the people made,

His strong troops will them invade."

Southwell is, if possible, worse. He paraphrases David, putting into his mouth such punning conceits as "fears are my feres," and in his "Saint Peter's Complaint" makes that rashest and shortest-spoken of the Apostles drawl through thirty pages of maudlin repentance, in which the distinctions between the north and northeast sides of a sentimentality are worthy of Duns Scotus. It does not follow, that, because a man is hanged for his faith, he is able to write good verses. We would almost match the fortitude that quails not at the good Jesuit's poems with his own which carried him serenely to the fatal tree. The stuff of which poets are made, whether finer or not, is of a very different fibre from that which is used in the tough fabric of martyrs. It is time that an earnest protest should be uttered against the wrong done to the religious sentiment by the greater part of what is called religious poetry, and which is commonly a painful something misnamed by the noun and misqualified by the adjective. To dilute David, and make doggerel of that majestic prose of the Prophets which has the glow and wide-orbited metre of constellations, may be a useful occupation to keep country-grentlemen out of litigation or retired clergymen from polemics; but to regard these metrical mechanics as sacred because nobody wishes to touch them, as meritorious because no one can be merry in their company, - to rank them in the same class with those ancient songs of the Church, sweet with the breath of saints, sparkling with the tears of forgiven penitents, and warm with the fervor of martyrs, - nay, to set them up beside such 
poems as those of Herbert, composed in the upper chambers of the soul that open toward the sun's rising, is to confound piety with dulness, and the manna of heaven with its sickening namesake from the apothecary's drawer. The "Enchiridion" of Quarles is hardly worthy of the author of the "Emblems," and is by no means an unattainable book in other editions, - nor a matter of heartbreak, if it were. Of the dramatic works of Marston and Lilly it is enough to say that they are truly works to the reader, but in no sense dramatic, nor, as literature, worth the paper they blot. They seem to have been deemed worthy of republication because they were the contemporaries of true poets; and if all the Tuppers of the nimeteenth century will buy their plays on the same principle, the sale will be a remunerative one. It was worth while, perhaps, to reprint Lovelace, if only to show what dull verses may be written lyy a man who has made one lucky hit. Of the "Early English Poetry," nine tenths had better never have been printed at all, and the other tenth reprinted by an editor who had some rague suspicion, at least, of what they meant. The Homer of Chapman is so precious a gift, that we are ready to forgive all Mr. Smith's shortcomings in consideration of it. It is a rast placer, full of nuggets for the philologist and the lover of poetry.

Having now rum cursorily through the series of Mr. Smith's reprints, we come to the closer question of Ilow are they celited? Whaterer the merit of the original works, the editors, whether self-clected or chosen by the publisher, should be accurate and scholarly. The editing of the Homer we can heartily commend; and Dr. Rimbault, who carried the works of Overbury through the press, has done his work well; but the other volumes of the Library are very creditable neither to English scholarship nor to English typography. The Intro- 
ductions to some of them are enough to make us think that we are fallen to the necessity of reprinting our old authors because the art of writing correct and graceful English has been lost. William B. Turnbull, Esq., of Lincoln's Inn, Barrister at Law, says, for instance, in his Introduction to Southwell: "There was resident at Uxendon, near Harrow on the Hill, in Middlesex, a Catholic family of the name of Bellamy whom [which] Southwell was in the habit of visiting and providing with religions instruction when he exchanged his ordinary [ordinarily] close confinement for a purer atmosphere." (p. xxii.) Again, (p. xxii,) "He had, in this mamner, for six years, pursued, with very great success, the objects of his mission, when these were abruptly terminated by his foul betrayal into the hands of his enemies in 1592." We should like to have Mr. Turnbull explain how the objects of a mission could be terminated by a betrayal, however it might be with the mission itself. From the many similar flowers in the Introduction to Mather's "Providences," by Mrr. George Offor, (in whom, we fear, we recognize a countryman,) we select the following: "It was at this period when, [that,] oppressed by the ruthless hand of persecution, our Pilgrim Fathers, threatened with torture and death, succumbed not to man, but trusting ou [in] an almighty arm, braved the dangers of an almost unknown ocean, and threw themselves into the arms of men called savages, who proved more beneficent than national Christians." To whom or what our Pilgrim Fathers did succumb, and what "national Christians" are, we leave, with the song of the Sirens, to conjecture. Speaiking of the "Providences," Mr. Offor says, that "they faithfully delineate the state of public opinion two hundred years ago, the most striking feature being an implicit faith in the power of the [in-] visible world to 
hold visible intercourse with man:- not the angels to bless poor erring mortals, but of demons imparting power to witches and warlocks to injure, terrify and destroy," - a sentence which we defy any witch or warlock, though he were Michael Scott himself, to parse with the astutest demonic aid. On another page, he says of Dr. Mather, that "he was one of the first divines who discovered that very many strange events, which were considered preternatural, had oceurred in the course of nature or by deceitful juggling; that the Devil could not speak English, nor prevail with Protestants; the smell of herbs alarms the Devil ; that medicine drives out Satan!" We do not wonder that Mr. Offor put a mark of exclamation at the end of this surprising sentence, but we do confess our astonishment that the vermilion peneil of the proof-reader suffered it to pass unchallenged. Leaving its bad English out of the question, we find, on reforring to Mather's text, that he was never guilty of the absurdity of believing that Satan was less eloquent in English than in any other language ; that it was the British (Welsh) tongue which a certain demon whose education had been neglected (not the Devil) could not speak; that Mather is not fool enough to say that the Fiend cannot prevail with Protestants, nor that the smell of herbs alarms him, nor that medicine drives him out. Anything more helplessly inadequate than Mr. Offor's preliminary dissertation on Witcheraft we nerer read; but we could hardly expect much from an editor whose citations from the book he is editing show that he had either not read or not understood it.

Mr. Offor is superbly Protestant and iconoclastic, not sparing, as we have scen, even Priscian's head among the rest; but, en revanche, $\mathrm{Mr}$. Turnbull is ultramontane beyond the editors of the Civilta Cattolioa. 
He allows himself to say, that, " after Southwell's death, one of his sisters, a Catholic in heart, but timidly and blamably simulating heresy, wrought, with some relics of the martyr, several cures on persons afflicted with desperate and deadly diseases, which had baffled the skill of all physicians." Mr. Turmbull is, we suspect, a recent convert, or it would occur to him that doctors are still secure of a lucrative practice in countries full of the relics of greater saints than even Southwell. That father was hanged (according to Protestants) for treason, and the relic which put the whole pharmacopœia to shame was, if we mistake not, his neckerchief. But whatever the merits of the Jesuit himself, and however it may gratify Mr. Turnbull's catechumenical enthusiasm to exalt the curative properties of this integument of his, even at the expense of Jesuits' bark, we cannot but think that he has shown a credulity that unfits him for writing a fair narrative of his hero's life, or making a tolerably just estimate of his verses. It is possible, however, that these last seem prosaic as a necktie only to heretical readers.

We have singled out the Introductions of Messrs. Turnbull and Offor for special animadversion because they are on the whole the worst, both of them being offensively sectarian, while that of $\mathrm{Mr}$. Offor in particular gives us almost no information whatever. Some of the others are not without grave faults, chief among which is a rague declamation, especially out of place in critical essays, where it serres only to weary the reader and awaken his distrust. In his Introduction to Wither's "Hallelujah," for instance, Mr. Farr informs us that "nearly all the best poets of the latter half of the sixteenth century - for that was the period when the Reformation was fully established - and the whole of the seventeenth century were sacred poets," and that "even 
Shakespeare and the contemporary dramatists of his age sometimes attuned their well-strung harps to the songs of Zion." Comment on statements like these would be as useless as the assertions themselves are absurd.

We have quoted these examples only to justify us in saying that Mr. Smith must select his editors with more care if he wishes that his "Library of old Authors" should deserve the confidence and thereby gain the good word of intelligent readers, - without which such a series can neither win nor keep the patronage of the public. It is impossible that men who camnot construct an English sentence correctly, and who do not know the value of clearness in writing; should be able to disentangle the knots which slovenly printers have tied in the thread of an old author's meaning; and it is more than doubtful whether they who assert carelessly, cite inaccurately, and write loosely are not by nature disqualified for doing thoroughly what they undertake to do. If it were unreasonable to demand of every one who assumes to edit one of our early poets the eritical acumen, the genial sense, the illimitable reading, the philological scholarship, which in combination would alone make the ideal editor, it is not presumptuous to expect some one of these qualifications singly, and we have the right to insist upon patience and accuracy, which are within the reach of every one, and without which all the others are wellnigh vain. Now to this virtue of accuracy Mr. Offor specifically lays claim in one of his remarkable sentences: "We are bound to admire," he says, "the accuracy and beauty of this specimen of typography. Following in the path of my late friend William Pickering, our publisher rivals the Aldine and Elzevir presses, which have been so universally admired." We should think that it was the pro- 
duct of those presses which had been admired, and that Mr. Smith presents a still worthier object of admiration when he contrives to follow a path and rival a press at the same time. But let that pass; - it is the claim to accuracy which we dispute; and we deliberately affirm, that, so far as we are able to judge by the rolumes we have examined, no claim more unfounded was ever set up. In some cases, as we shall show presently, the blunders of the original work have been followed with painful accuracy in the reprint; but many others have been added by the carelessness of Mr. Smith's printers or editors. In the thirteen pages of Mr. Offor's own Introduction we have found as many as seven typographical errors, - unless some of them are to be excused on the ground that Mr. Offor's studies have not yet led him into those areana where we are taught such recondite mysteries of language as that verbs agree with their nominatives. In MIr. Farr's Introduction to the "Hymns and Songs" nine short extracts from other poems of Wither are quoted, and in these we have found no less than seven misprints or false readings which materially affect the sense. Textual inaccuracy is a grave fault in the new edition of an old poet; and Mr. Farr is not only liable to this charge, but also to that of making blundering misstatements which are calculated to mislend the careless or uncritical reader. Infected by the absurd cant which has been prevalent for the last dozen years among literary sciolists, he says, - "The langunge used by Wither in all his various works - whether secular or sacred - is pure Saxon." Taken literally, this assertion is manifestly ridiculous, and, allowing it every possible limitation, it is not only untrue of Wither, but of every English poet, from Chaucer down. The translators of our. Bible made use of the German version, and a poet versifying the English Seriptures would 
therefore be likely to use more words of Teutonic origin than in his original compositions. But no English poet can write English poetry except in English, - that is, in that compound of Teutonic and Romanic which derives its heartiness and strength from the one and its canorous elegance from the other. The Saxon language does not sing, and, though its tough mortar serve to hold together the less compact Latin words, porous with rowels, it is to the Latin that our verse owes majesty, harmony, variety, and the capacity for rhyme. A quotation of six lines from Wither ends at the top of the very page on which Mr. Farr lays down his extraordinary dictum, and we will let this answer him, Italicizing the words of Romance derivation :-

" Her true beauty leaves behind Apprehensions in the mind, Of more sweetness than all art Or inventions can impart; Thoughts too deep to be expressed, And too strong to be suppressed."

Mr. Halliwell, at the close of his Preface to the Works of Marston, (Tol. I. p. xxii,) says, "The dramas now collected together are reprinted absolutely from the early editions, which were placed in the hands of our printers, who thus had the advantage of following them without the intervention of a transeriber. They are given as nearly as possible in their original state, the only modemizations attempted consisting in the alternations of the letters $i$ and $j$, and $u$ and $v$, the retention of which" (does Mrr. Halliwell mean the letters or the "altcrmations"?) "would hive answered no useful purpose, while it would have unnecessarily perplexed the modern reader."

This is not very clear; but as Mr. Halliwell is a mem. ber of severit learned foreign societies, and especially of 
the Royal Irish Academy, perhaps it would be unfair to demand that he should write clear English. As one of Mr. Smith's editors, it was to be expected that he should not write it idiomatically. Some malign constellation (Taurus, perhaps, whose infuust aspect may be supposed to preside orer the makers of bulls and blunders) seems to have been in conjunction with heary Saturn when the Library was projected. At the top of the same page from which we have made our quotation, Mr. Halliwell speaks of "conveying a favorable impression on modern readers." It was surely to no such phrase as this that Ensign Pistol alluded when he said, "Convey the wise it call."

A literal reprint of an old author may be of value in two ways : the orthography may in certain cases indicate the ancient pronunciation, or it may put us on a scent which shall lead us to the burrow of a word among the roots of language. But in order to this, it surely is not needful to undertake the reproduction of all the original errors of the press; and even were it so, the proofs of carelessness in the editorial department are so glaring, that we are left in doubt, after all, if we may congratulate ourselves on possessing all these sacred blunders of the Elizabethan type-setters in their integrity, and without any debasement of modern alloy. If it be gratifying to know that there lived stupid men before our contemporary Agamemnons in that kind, yet we demand absolute accuracy in the report of the phenomena in order to arrive at anything like safe statistics. For instance, we find (Vol. I. p. 89) "Actus Secundus, Scexa Primus," and (Vol. III. p. 174) "exit cmbo," and we are interested to know that in a London printing-house, two centuries and a half ago, there was a philanthropist who wished to simplify the study of the Latin language by reducing all the nouns to one gender and all the verbs to ono 
number. Had his emancipated theories of grammar prevailed, how much easier would that part of boys which cherubs want have found the school-room benches! How would birchen bark, as an educational tonic, have fallen in repute! How white would have been the (now black-and-blue) memories of Dr. Busby and so miny other educational lictors, who, with their bundles of rods, heralded not alone the consuls, but all other Roman antiquities to us! We dare not, however, indulge in the grateful vision, since there are circumstances which lead us to infer that Mr. Halliwell himself (member though he be of so many learned socicties) has those vague notions of the speech of ancient Rome which are apt to prevail in regions which count not the betula in their Flora. On page xv of his Preface, he makes Drummond say that Ben Jonson "was dilated" (deluted, - Gifford gives it in English, accused) "to the king by Sir James Aurray," - Ben, whose corpulent person stood in so little need of that malicious increment!

What is Mr. Halliwell's conception of editorial duty? As we read along, and the once fair complexion of the margin grew more and more pitted with pencil-marks, like that of a bad proof-sheet, we began to think that he was acting on the principle of every man his own washerwoman, - that he was making blunders of set purpose, (as teachers of languages do in their excreises, ) in order that we might correct them for ourselves, and so fit us in time to be editors also, and members of various learned societies, even as Mr. Halliwell himself is. We fancied, that, magnanimously waving aside the laurel with which a grateful posterity crowned General Wade, he wished us "to sce these roads before they were made," and develop our intellectual muscles in getting over them. But no; Mr. Halliwell has appended notes to his edition, and among them are some which correct misprints, 
and therefore seem to imply that he considers that service as belonging properly to the editorial function. Te are obliged, then, to give up our theory that his intention was to make every reader an editor, and to suppose that he wished rather to show how disgracefully a book might be edited and yet receive the commendation of professional critics who read with the ends of their fingers. If this were his intention, Marston himself never published so biting a satire.

Let us look at a few of the intricate passages, to help us through which Mr. Halliwell lends us the light of his editorial lantern. In the Induction to "What you Will" occurs the striking and unusual phrase, "Now out uppont," and Mr. Halliwell favors us with the following note: "Page 221, line 10. Up-pont. - That is, upon 't." Again in the same play we find -

"Let twattling fame cheatd others rest,
I um no dish for rumors feast."

Of course, it should read, -

"Let twattling [twaddling] Fame cheate others' rest,

I am no dish for Rumor's feast."

Mr. Halliwell comes to our assistance thus: "Page 244, line 21, [22 it should be,] I um, - a printer's error for I am." Dignus vindice nodus! Five lines above, we have "whole" for "who "ll," and four lines below, "helmeth" for "whelmeth"; but Mr. Halliwell vouchsafes no note. In the "Fawn" we read, "Wise neads use few words," and the editor says in a note, "a misprint for heads" ! Kind Mr. Halliwell!

Having given a ferw examples of our "Editor's" corrections, we proceed to quote a passage or two which, it is to be presumed, he thought perfectly clear.

"A man can skarce put on a tuckt-up cap, A button'd frizado sute, skarce eate good meate, Anchoves, caviare, but hee's satyred 
And term'd phantasticall. By the muddy spawne Of slymie neughtes, when troth, phantasticknesse That which the naturall sophysters tearme

Phantusia incomplexa - is a function

Even of the bright immortal part of man.

It is the common passe, the sacred dore,

Unto the prive chamber of the soule;

That bar'd, nought passeth past the baser court

Of outward scence by it th' inamorate

Most lively thinkes he sees the absent beauties

Of his lov'd mistres." (Vol. I. p. 241.)

In this case, also, the true readings are clear enough :-

"And termed fantastical by the muddy spawn

and

$$
\text { Of slimy newts"; }
$$

Of outward sense"; ;

but, if anything was to be explained, why are we here deserted by our fida compragna? Again, (Vol. II. pp. 55 , 56,) we read, "This Grmuffo is a right wise good lord, a man of excellent discourse, and nerer speakes his signes to me, and men of profound reach instruct aboumdantly; hee begres suites with signes, gives thanks with signes," ete. This Granuffo is qualified among the "Interlocutors" as " "a silent lord," and what fun there is in the character (which, it must be confessed, is rather of a lenten kind) consists in his genius for saying nothing. It is plain enough that the passage should read, "a man of excellent discourse, and nerer speaks; his signs to me and men of profound reach instruct abundantly," etc.

In both the passaces we have quoted, it is not difficult for the reader to set the text right. But if not difficult for the reader, it should certainly not have been so for the editor, who shoule have done what Broome was said to have done for Pope in his Homer, _ "gone before and swept the way." An edition of an English author ought to be intelligible to English readers, and, if the 
editor do not make it so, he wrongs the old poet, for two conturies lapt in lead, to whose works he undertakes to play the gentleman-usher. A play written in our own tongue should not be as tough to us as Eschylus to a ten years' graduate, nor do we wish to be reduced to the lcvel of a chimpanzec, and forced to gnaw our way through a thick shell of misprints and mispointings only to find (as is generally the ease with Marston) a rancid kernel of meaning after all. But even Marston sometimes deviates into poetry, as a man who wrote in that age could hardly help doing, and one of the few instances of it is in a speech of Erichtho, in the first scene of the fourth act of "Sophonisba," (Vol. I. p. 197,) which Mr. Halliwell presents to us in this shape :-

"hardby the reverent (!) ruines

Of a once glorious temple rear'd to Jove

Whose very rubbish

- . . . yet beares

A deathlesse majesty, though now quite rac'd, [razed,]

Hurl'd down by wrath and lust of impious kings,

So that where holy Flamins [Flamens] wont to sing

Sweet hymnes to Heaven, there the daw and crow,

The ill-voye'd raven, and still chattering pye,

Send out ungratefull sounds and loathsome filth;

Where statues and Joves acts were vively limbs,

Where tombs and beautious urnes of well dead men

Stood in assured rest," etc.

The last verse and a half are worthy of Chapman; but why did not Mr. Halliwell, who explains up-pont and $I$ um, change "Joves acts were vively limbs" to "Jore's ncts were lively limned," which was unquestionably what Marston wrote?

In the "Scourge of Villanie," (Tol. III. p. 252,) there is a passage which till lately had a modern application in America, though happily archaic in England, which Mr. Halliwell suffers to stand thus :- 
"Once Albion lived in such a cruel age Than man did hold by servile vilenage:

Poore brats were slaves of bondmen that were borne, And marted, sold: but that rude law is torne And disannuld, as too too inhumane."

This should read -

"Man man did hold in servile villanage;

Poor brats were slaves (of bondmen that were born)"; and perhaps some American poet will one day write in the past tense similar verses of the barbarity of his fore. fathers.

We will give one more serap of Mr. Halliwell's text :-

"Y faith, why then, caprichious mirth, Skip, light moriscoes, in our frolick blond, Fligg'd veines, sweete, plump with fresh-infused joyes!" which Marston, doubtless, wrote thus : -

"I'faith, why then, capricious Mirth, Skip light moriscoes in our frolic blood! Flagg'd veins, swell plump with fresh-infused joys!"

We have quoted only a few examples from among the scores thit we had marked, and against such a style of "editing "we invoke the shade of Marston himself. In the Preface to the Second Erlition of the "Fawn," ho says, "Reader, know I have perused this coppy, to malie some satisfaction for the first faulty impression; yet so urgent hath been my business that some errors have styll passed, which thy discretion may amend."

Literally, to be sure, Mr. Halliwell has availed himself of the permission of the poet, in leaving all emendation to the reader; but certainly he has been false to the spirit of it in his self-assumed office of editor. The notes to explain up-pont and $I$ um give us a kind of standard of the highest intelligence which MIr. Halliwell dares to take for granted in the ordinary reader. Supposing this nousometer of his to be a centigrade, in what hitherto unconceived depths of cold obstruction can he find his zero-point of entire idiocy? The expansive force 
of average wits camnot be reckoned upon, as we see, to drive them up as far as the temperate degree of misprints in one syllable; and those, too, in their native tongue. A fortiori, then, Mr. Halliwell is bound to lend us the aid of his great learning wherever his author has introduced foreign words and the old printers have made pie of them. In a single case he has accepted his responsibility as dragoman, and the amount of his success is not such as to give us any poignant regret that he has everywhere else left us to our own devices. On p. 119, Vol. II., Francischina, a Dutchwoman, cxclaims, "O, mine aderliver love." Here is Mr. Halliwell's note. "Aderliver. - This is the speaker's error for alder-licver, the best beloved by all." Certainly not "the speaker's error," for Marston was no such fool as intentionally to make a Dutchwoman blunder in her own language. But is it an error for alderliever? No, but for alderliefster. Mr. Halliwell might have found it in many an old Dutch song. For example, No. 96 of Hoffmann von Fallersleben's "Niederländische Volkslieder" begins thus :-

"Nijin hert altijt heeft verlanghen

Naer u, die alderliefste mijn."

But does the word mean "best beloved by all"? No such thing, of course; but "best beloved of all," that is, by the speaker.

In "Antonio and Mellida" (Vol. I. pp. 50, 51) occur some Italian verses, and here we hoped to fare better; for Mr. Halliwell (as we learn from the title-page of his Dictionary) is a member of the "Reale Academia di Firenze." This is the Accademia della Crusca, founded for the conservation of the Italian language in its purity, and it is rather a fatal symptom that Mr. Halliwell should indulge in the heresy of spelling Accademia with only one $c$. But let us see what our Della Cruscan's notions of conserving are. Here is a specimen :- 


\section{"Bassiammi, coglier l' aura odorata}

Che in sua neggia in quello dolce labra.

Dammi pimpero del tuo gradit' amore."

It is clear enough that we ought to read,

"Lasciami coglier, ... . Che ha sua seggia, ... Dammi l' impero."

A Della Cruscan academician might at least have cor. rected by his dictionary the spelling and number of labra.

We think that we have sustained our indictment of Mr. Halliwell's text with ample proof. The title of the book should have been, "The Works of John Marston, containing all the Misprints of the Original Copies, together with a few added for the First Time in this Edition, the whole carefully let alone by James Orchard Halliwell, F. R. S., F. S. A." It occurs to us that Mr. Halliwell may be also a Fellow of the Geological Society, and may have caught from its members the enthusiasm which leads him to attach so extriordinary a value to every groose-track of the Elizahethan formation. It is bad enough to be, as Marston was, one of those middling poets whom neither gods nor men nor columns (Horace had never scen a newspaper) tolerate; but, really, even they do not deserve the frightful retribution of being reprinted by a Halliwell.

We have said that we could not feel even the dubious satisfaction of knowing that the blunders of the old copies had been faithfully followed in the reprinting. We see reason for doubting whether Mr. Halliwell ever read the proof-sheets. In his own notes we have found sevcral mistikles. For instance, he refers to p. 159 when he means p. 153; he cites "I, but her life," instead of "lip" ; and he makes Spenser speak of "old Pithonus." Marston is not an author of enough importance to make it desirable that we should be put in possession of all the corrupted readings of his text, were such a thing 
possible even with the most minute painstaking, and $\mathrm{Mr}$. Halliwell's edition loses its only claim to value the moment a doubt is cast upon the accuracy of its inaccuracies. It is a matter of special import to us (whose means of access to originals are exceedingly limited) that the English editors of oux old authors should be faithful and trustworthy, and we have singled out Mr. Halliwell's Marston for particular animadversion only because we think it on the whole the worst edition we ever saw of any author.

Having exposed the condition in which our editor has left the text, we proceed to test his competency in another respect, by examining some of the emendations and explanations of doubtful passages which he proposes. These are very few ; but had they been even fewer, they had been too many.

Among the dramatis personce of the "Fawn," as we said before, occurs "Granuffo, a silent lord." He speaks only once during the play, and that in the last scene. In Act I. Scene 2, Gonzago says, speaking to G'ranuffo, -

\section{"Now, sure, thou art a man}

Of a most learned scilence, and one whose words Have bin most pretious to me."

This seems quite plain, but Mr. Halliwell annotates thus: "Scilence. - Query, science? Th. :nmmon reading, silence, may, however, be what is intencec.' That the spelling should have troubled Mr. Halliwell is remarkable; for elsewhere we find "god-boy" for "goodbye," "seace" for " cease," " bodies" for "boddice," "pollice" for "policy," "pitittying" for " pitying," "scence" for "sense," "Misenzius" for "Mrezentius," "Ferazes" for "Ferrarese," — and plenty beside, equally odd. That he should have doubted the meaning is no less strange ; for on p. 41 of the same play we read, "My Lord Granuffo, you may likewise stay, for I know 
you'l say nothing," - on pp. 55, 56, "This Granuffo is a right wise good lord, a man of excellent disconrse and never speaks," - and on p. 94, we find the following dialogue :

"Gon. My Lord Granuffo, this Fawne is an excellent fellow.

"Don. Silence.

"Gon. I warrant you for my lord here.

In the same play (p. 44) are these lines :-

"I apt for love?

Let lazy idlenes fild full of wine

Heated with meates, high fedde with lustfull ease

Goe dote on culler [color]. As for me, why, death a sence, I court the ladie?"

This is Mr. Halliwcll's note: "Denth a sence._- "Earth a sense,' ed. 1633. Mr. Dilke suggests : 'For me, why, earth's as sensible.' The original is not necessarily corrupt. It may mean, - why, you might as well think Death was a sense, one of the senses. See a like phrase at p. 77." What help) we should get by thinking Death one of the senses, it would demand another Edipus to umriddle. Mr. Halliwell can astonish us no longer, but we are surprised at Mrr. Dilke, the very competent editor of the "Old English Plays," 1815. From him we might have hoped for better things. "Death o' sense!" is an exclame on. Throughout these volumes we find a for o", - as, "a clock" for "o'clock," "a the side" for "o' the side." A similar exclamation is to be found in three other places in the same play, where the sense is obvious. Mr. Halliwell refers to one of them on p. $77, \ldots$ "Death a man! is she delivered?" The others are, _- "Death a justice! are we in Normandy?" (p. 98); and "Death a discretion! if I should prove a foole now," or, as given by Mr. Halliwell, "Death, a discretion!" Now let us apply Mr. Halliwell's explanation. "Death a man!" you might as well think Death was a man, 
that is, one of the men! - or a discretion, that is, one of the discretions! - or a justice, that is, one of the quorum! We trust Mr. Halliwell may never have the editing of Bob Acres's imprecations. " Odd's triggers!" he would say, "that is, as odd as, or as strange as, triggers."

Vol. III. p. 77, "the vote-killing mandrake." Mr. Halliwell's note is, "vote-killing. - 'Voice-killing,' ed. 1613. It may well be doubted whether either be the correct reading." He then gives a familiar citation from Browne's "Vulgar Errors." "Vote-killing" may be a mere misprint for " note-killing;" but "voice-killing" is certainly the better reading. Either, however, makes sense. Although Sir Thomas Browne does not allude to the deadly property of the mandrake's shrick, yet Mr. Halliwell, who has edited Shakespeare, might have remembered the

"Would curses kill, as doth the mandrake's groan."

(Second Part of Henry VI., Act III. Scene 2.)

and the notes thereon in the variorum edition. In Jacob Grimm's "Deutsche Mythologie," (Vol. II. p. 1154,) under the word Alroun, may be found a full account of the superstitions concerning the mandrake. "When it is dug up, it groans and shrieks so dreadfully that the digger will surely die. One must, therefore, before sunrise on a Friday, having first stopped one's cars with wax or cotton-wool, take with him an entirely black dog without a white hair on him, make the sign of the cross three times over the alraun, and dig about it till the root holds only by thin fibres. Then tie these by a string to the tail of the dog, show him a piece of bread, and rum away as fast as possible. The dog runs eagerly after the bread, pulls up the root, and falls stricken dead by its groan of pain."

These, we beliere, are the only instances in which Mr. Halliwell has rentured to give any opinion upon the 
text, except as to a palpable misprint, here and there Two of these we have already cited. There is one other, - "p. 46, line 10. Iuconstant. - An error for inconstant." Wherever there is a real difficulty, he leaves us in the lurch. For eximple, in "What you Will," he prints without comment, -

"Ha! he mount Chirall on the wings of fame !"

(Vol. I. p. 239.)

which should be "mount cheval," as it is given in Mr. Dilke's edition (Old English Plays, Vol. II. p. 222). We cite this, not as the worst, but the shortest, example at hand.

Some of Mr. Halliwell's notes are useful and interesting, - as that on "kecling the pot," and a few others, - but the greater part are utterly useless. He thinks it necessary, for instance, to explain that "to speck pure foole, is in sense equivalent to "I will speak like a pure fool," "- that "belkt up" means "belched up," - that "aprecocks" means "apricots." He has notes also upon " "meal-mouthed," "luxuriousnesse," "termagant," "fico," "estro," "a nest of goblets," which indicate either that the "gencral reader" is a less intelligent person in England than in America, or that Mr. Ialliwell's standard of scholarship is rery low. We ourselves, from our limited reading, can supply him with a reference which will explain the allusion to the "Scotch barnacle" much better than his citations from Sir John Maundeville and Giraldus Cambrensis, - namely, note 8, on page 179 of a Treatise on Worms, by Dr. Ramesey, court physician to Tharles II.

We tirn now to Mr. Hazlitt's edition of Webster. We wish he had chosen Chapman; for Mr. Dyce's Webster is hardly out of print, and, we believe, has just gone through a second and revised edition. Webster was a 
far more considerable man than Marston, and infinitely above him in genius. Without the poetic nature of Narlowe, or Chapman's somewhat unwieldy rigor of thought, he had that inflammability of mind which, untempered by a solid understanding, made his plays a strange mixture of vivid expression, incoherent declamation, dramatic intensity, and extraragant conception of character. He was not, in the highest sense of the word, a great dramatist. Shakespeare is the only one of that age. Narlowe had a rare imagination, a delicacy of sense that made him the teacher of Shakespeare and Milton in versification, and was, perhaps, as purcly a poet as any that England has produced; but his mind had no balance-wheel. Chapman abounds in splendid enthusiasms of diction, and now and then dilates our imaginations with suggestions of profound poctic depth. Ben Jonson was a conscientious and intelligent workman, whose plays glow, here and there, with the golden pollen of that poetic feeling with which his age impregnated all thought and expression; but his leading characteristic, like that of his great namesake, Samuel, was a hearty common sense, which fitted him rather to be a great critic than a great poet. He had a keen and ready eye for the comic in situation, but no humor. Fletcher was as much a poet as fancy and sentiment can make any man. Only Shakespeare wrote comedy and tragedy with truly ideal elevation and breadth. Only Shakespeare had that true sense of humor which, like the universal solvent sought by the alchemists, so fuses together all the elements of a character, (as in Falstaff,) that any question of good or evil, of dignified or ridiculous, is silenced by the apprehension of its thorough humanity. Rabelais shows gleams of it in Panurge; but, in our opinion, no man ever possessed it in an equal degree with Shakespeare, except Cerrantes; no man has since 
shorm anything like an approach to it, (for Molière's quality was comic power rather than humor, ) except Sterne, Fichling, and perhaps Richter. Only Shakespeare was endowed with that healthy equilibrium of nature whose point of rest was midway between the imagination and the understanding, - that perfectly unruffled brain which reflected all objects with almost inhuman impartiality, - that outlook whose range was ecliptical, dominating all zones of human thought and action, - that power of veri-similar conception which could take arvay Iichard III. from History, and Ulysses from Homer, and that creative faculty whose equal touch is alike vivifying in shallow and in Lear. He alone never sceks in abnormal and monstrous characters to evade the risks and responsibilities of absolute truthfulness, nor to stimulate a jaded imagrination by Caligulan horrors of plot. He is never, like many of his fellow-dramatists, confronted with unnatural Frankensteins of his own making, whom he must get off his hands as hest he may. Given a humau foible, he can incarnate it in the nothingness of Slender, or make it loom gigantic through the tragic twilight of Hamlet. We are tired of the ragueness which classes all the Elizabethan playwrights together as "great dramatists," - as if Shakespeare did not differ from them in kind as well as in degree. Fine poets some of them were; but though imagination and the power of poctic expression are, singly, not uncommon gifts, and eren in combination not without secular $\mathrm{ex}-$ amples, yet it is the rarest of earthly phenomena to find them joined with those faculties of perception, arrangement, and plastic instinct in the loving union which alone makes a great dramatic poet possible. We suspect that Shakespeare will long continue the only specimen of the genus. His contemporaries, in their comedies, either force what they call "a humor" till it becomes 
fantastical, or hunt for jokes, like rat-catchers, in the sewers of human nature and of language. In their tragedies they become heavy without grandeur, like Jonson, or mistake the stilts for the cothurnus, as Chapman and Webster too often do. Every new edition of an Elizabethan dramatist is but the putting of another witness into the box to prove the inaccessibility of Shakespeare's stand-point as poet and artist.

Webster's most famous works are "The Duchess of Malfy" and "Vittoria Corombona," but we are strongly inclined to call "The Devil's Law-Case" his best play. The two former are in a great measure answerable for the "spasmodic" school of poets, since the extravagances of a man of genius are as sure of imitation as the equable self-possession of his higher moments is incapable of it. Webster had, no doubt, the primal requisite of a poct, imagination, but in him it was truly untamed, and Aristotle's admirable distinction between the Horrible and the Terrible in tragedy was never better illustrated and confirmed than in the "Duchess" and "Vittoria." His nature had something of the sleuth-hound quality in it, and a plot, to keep his mind eager on the trail, must be sprinkled with fresh blood at every turn. We do not forget all the fine things that Lamb has said of Webster, but, when Lamb wrote, the Elizabethan drama was an El Dorado, whose micaceous sand, even, was treasured as auriferous, - and no wonder, in a generation which admired the "Botanic Garden." Webster is the Gherardo della Notte of his day, and himself calls his "Vittoria Corombona" a "night-piece." Though he had no conception of Nature in its large sense, as something perrading a whole character and making it consistent with itself, nor of Art, as that which dominates an entire tragedy and makes all the characters foils to each other and tributaries to the catastrophe, yet there are 
flashes of Nature in his plays, struck out by the collisions of passion, and dramatic intensities of phrase for which it would be hard to find the match. The "prithee, undo this button" of Lear, by which Shakespeare makes us feel the swelling of the old king's heart, and that the bodily results of mental anguish have gone so far as to deaden for the moment all intellectual consciousness and forbid all expression of grief, is hardly finer than the broken verse which Webster puts into the mouth of Ferdinand when he sees the body of his sister, murdered by his own procurement :-

"Cover her face: mine eyes dazzle: she died young."

He has not the condensing power of Shakespeare, who squeezed meaning into a phrase with an hydraulic press, but he could carve a cherry-stone with any of the concettisti, and abounds in imaginative quaintnesses that are worthy of Domne, and epigrammatic tersenesses that remind us of Fuller. Nor is he wanting in poetic phrases of the purest crystallization. Here are a few examples :-

"Oh, if there be another world i' th' moon,

As some fantastics dream, I could wish all men,

The whole race of them, for their inconstancy,

Sent thither to people that!"

(Old Chancer was yet slier. After saying that Lamech was the first faithless lover, he adds, -

"And he invented tents, unless men lie," implying that he was the prototype of nomadic men.)

"Virtue is ever sowing of her seeds:

In the trenches, for the soldier; in the wakeful study,

For the scholar; in the furrows of the sea,

For men of our profession [merchants]; all of which

Arise and spring up honor."

("Of all which," Mr. Hazlitt prints it.)

"Poor Jolenta! should she hear of this, She would not after the report keep fresh

So long as flowers on graves." 
"For sin and shame are ever tied together

With Gordian knots of such a strong thread spun,

They cannot without violence be undone."

"One whose mind

Appears more like a ceremonious chapel

Full of sweet music, than a thronging presence."

"What is death?

The safest trench i' th' world to keep man free

From Fortune's gunshot."

"It has ever been my opinion

That there are none love perfectly indeed,

But those that hang or drown themselves for love,"

says Julio, anticipating Butler's

"But he that drowns, or blows out 's brains,

The Devil's in him, if he feigns."

He also anticipated La Rochcfoucauld and Byron in their apophthegm concerning woman's last love. In "The Devil's Law-Case," Leonora says, -

"For, as we love our youngest children best,

So the last fruit of our affection,

Wherever we bestow it, is most strong,

Most violent, most unresistible;

Since 't is, indeed, our latest harvest-home,

Last merriment 'fore winter."

In editing Webster, Mr. Hazlitt had the advantage (except in a single doubtful play) of a predecessor in the Rev. Alexander Dyce, beyond all question the best living scholar of the literature of the times of Elizabeth and James I. If he gire no proof of remarkable fitness for his task, he seems, at least, to have been diligent and painstaking. His notes are short and to the point, and - which we consider a great merit - at the foot of the page. If he had added a glossarial index, we should have been still better pleased. Nir. Hazlitt seems to have read over the text with some care, and he has had the good sense to modernize the orthography, or, as ne says, has "observed the existing standard of spelling 
throughout." Yet - for what reason we cannot imagine - he prints "I" for "ay," taking the pains to explain it every time in a note, and retains "banqueront" and "coram" apparently for the sake of telling us that they mean "bankrupt" and "quorum." He does not seem to have a quick ear for scansion, which would sometimes have assisted him to the true reading. We give an example or two :-

"The obligation wherein we all stood bound

Cannot be concenled [cancelled] without great reproach."

"The realm, not they,

Must be regarded. Be [we] strong and bold,

We are the people's factors."

"Shall not be o'erburdened [overburdened] in our reign

\section{"A merry heart}

And a good stomach to [a] feast are all."

"Have her meat serv'd up by bawds and ruffians." [dele "up."]

"Brother or father

In [a] dishonest suit, shall be to me."

"What's she in Rome your greatness cannot awe,

Or your rich purse purchase? Promises and threats." [dele the second "your."]

"Through clouds of envy and clisast [rous] change."

"The Devil drives; "tis [it is] full time to go."

He has orcrlooked some strange blunders. What is the meaning of

"Laugh at your misery, as foredeeming you An idle meteor, which drawn forth, the earth Would soon be lost i' the air"?

Te hardly need say that it should be

"An idle meteor, which, drawn forth the earth, Would," \&c.

"Forwardness" for frowardness," (Vol. II. p. 87,) "tennis-balls struck and banded" for "bandied," (Ib. p. 275,) may be errors of the press; but . 
has crept in by editorial oversight for "wisely, that 's jealously." So have

and

"Ay, the great emperor of $[o r]$ the mighty Cham";

and

"This wit [with] taking long journeys";

"Virginius, thou dost but supply my place, I thine: Fortune hath lift me [thee] to my chair, And thrown me headlong to thy pleading bar";

and

" I'll pour my soul into my daughter's belly, [body,]

And with my soldier's tears embalm her wounds."

We suggest that the change of an $a$ to an $r$ would make sense of the following: "Come, my little punk, with thy two compositors, to this unlawful paintinghouse," [printing-house,] which Mr. Hazlitt awkwardly endeavors to explain by this note on the word compositors, - "i. e. (conjecturally), making up the composition of the picture"! Our readers can decide for themselves; - the passage occurs Vol. I. p. 214.

We think Mr. Hazlitt's notes are, in the main, good; but we should like to know his authority for saying that pench means "the hole in a bench by which it was taken up," - that "descant" means "look askant on,"- and that "I wis" is equivalent to "I surmise, imagine," which it surely is not in the passage to which his note is appended. On page 9, Vol. I., we read in the text,

"To whom, my lord, bends thus your awe,"

and in the note, "i. e. submission. The original has aue, which, if it mean ave, is unmeaning hore." Did Mr. Hazlitt never see a picture of the Annunciation with ave written on the scroll proceeding from the bending angel's mouth? We find the same word in Vol. III. p. 217 :-

"Whose station's built on avees and applause."

Vol. III. pp. 47, 48 :- 
"And then rest, gentle bones; yet pray That when by the precise you are view'd, A supersedeas be not sued To remove you to a place more airy, That in your stead they may keep chary Stockfish or seacoal, for the abuses

Of sacrilege have turned graves to viler uses."

To the last rerse Mr. Hazlitt appends this note, "Than that of burning men's bones for fucl." There is no allusion here to burning men's bones, but simply to the desecration of graverards by building warehouses upon them, in digging the foundations for which the bones would be throm out. The allusion is, perhaps, to the "Churchyard of the Holy Trinity"; - see Stow's Survey, ed. 1603, p. 126. Elsewhere, in the same play, Webster alludes bitterly to "begging church-land."

Vol. I. p. 73, "And if he walk through the street, he ducks at the penthouses, like an ancient that dares not flourish at the oathtaking of the protor for fear of the signposts." Mr. Hazlitt's note is, "Ancient was a standard or flag; also an ensign, of which Skinner says it is a corruption. What the meaning of the simile is the present editor camnot suggest." We confess we find no diffculty. The meaning plainly is, that he ducks for fear of hitting the penthouses, as an ensign on the Lord Mayor's day dares not flourish his standard for fear of hitting the signposts. We suggest the query, whether ancient, in this sense, be not a corruption of the Italian word anziano.

Want of space compels us to leare many other passages, which we had marked for comment, unnoticed. We are surprised that Mr. Hazlitt, (see his Introduction to "Vittoria Corombona,") in undertaking to give us some information concerning the Dukedom and Castle of Bracciano, should uniformly spell it Brachiano. Shakespeare's Petruchio might have put him on his guard. 
We should be glad aiso to know in what part of Italy he places Malfi.

Mr. Hazlitt's General Introduction supplies us with no new information, but this was hardly to be expected where Mr. Dyce had already gone orer the field. We wish that he had been able to give us better means of distinguishing the three almost contemporary John Websters one from the other, for we think the internal evidence is enough to show that all the plays attributed to the author of the "Duchess" and "Vittoria" could not have been written by the same person. On the whole, he has given us a very respectable, and certainly a very pretty, edition of an eminent poet.

We could almost forgive all other shortcomings of Mr. Smith's library for the great gift it brings us in the five volumes of Chapman's translations. Coleridge, sending Chapman's Homer to Wordsworth, writes, "What is stupidly said of Shakespeare is really true and appropriate of Chapman ; mighty faults counterpoised by mighty beanties. . . . It is as truly an original poom as the Faery Queene; - it will give you small idea of Homer, though a far truer one than Pope's epigrams, or Cowper's cumbersome most anti-Homeric Kiltonism. For Chapman writes and feels as a poet, - as Homer might hare written had he lived in England in the reign of Queen Elizabeth. In short, it is an exquisite poem, in spite of its frequent and perverse quaintnesses and harshnesses, which are, however, amply repaid by almost unexampled sweetness and beauty of language, all over spirit and fecling." * From a passage of his Preface it would appear that Chapman had been criticised pretty sharply in his own day for amplifying his anthor. "And this one example I thought necessary to insert here to show * Literary Remains, Vol. I. pp. 259, 260. 
my detractors that they have no reason to vilify my circumlocution sometimes, when their most approved. Greeims, Homer's interpreters generally, hold him fit to be so converted. Yet how much I differ, and with what authority, let my impartial and judicial reader judge. Always conceiving how pedantical and absurd an affectation it is in the interpretation of any author (much more of Homer) to turn him word for word, when (according to Horace and other best lawgivers to translators) it is the part of every knowing and judicial interpreter not to follow the number and order of words, but the material things themselves, and sentences to weigh diligently, and to clothe and adorn them with words and such a style and form of oration as are most apt for the language in which they are converted." Again in his verses To the Reader, he speaks of

"The ample transmigration to be shown By nature-loving Poesy,"

and defends his own use of "needful periphrases," and says that "word for word" translation is to

"Make fish with fowl, camels with whales, engender."

"For even as different a production

Ask Greek and English : since, as they in sounds

And letters shun one form and unison,

So have their sense and elegancy bounds

In their distinguished natures, and require

Only a judgment to make both consent

In sense and elocution."

There are two theories of translation, - literal paraphrase and free reproduction. At bost, the translation of poetry is but an imitation of natural flowers in cambric or wax ; and howerer much of likeness there may be, the aroma, whose charm of indefinable suggestion in the association of ideas is so powerful, is precisely what is lost irretrierably. From where it lurked in the immortal verse, a presence divined rather than ascertained, 
baffling the ear which it enchanted, escaping the grasp which-yet it thrilled, airy, evanescent, imperishable, beckoning the imagination with promises better than any fulfilment,

"The parting genius is with sighing sent."

The paraphrase is a plaster-cast of the Grecian urn; the reproduction, if by a man of genius, is like Keats's ode, which makes the figures move and the leares tremble again, if not with the old life, with a sorcery which deceives the fancy. Of all English poets, Keats was the one to have translated Homer.

In any other than a mere prose version of a great poem, we have a right to demand that it give us at least an adequate impression of force and originality. We have a right to ask, If this poem were published now for the first time, as the work of a contemporary, should we read it, not with the same, but with anything like the same conviction of its freshness, vigor, and originality, its high level of style and its witchery of verse, that Homer, if now for the first time discovered, would infallibly beget in us? Perhaps this looks like asking for a new Homer to translate the old one; but if this be too much, it is certainly not unfair to insist that the feeling given us should be that of life, and not artifice.

The Homer of Chapman, whatever its defects, alone of all English versions has this crowning merit of being, where it is most successful, thoronghly alive. He has made for us the best poem that has yet been Englished out of Homer, and in so far gives us a truer idea of him. Of all translators he is farthest remored from the fiult with which he charges others, when he says that "our divine master's most ingenious imitating the life of things (which is the sonl of a poem) is nerer respected nor perceived by his interpreters only standing pedantically on 
the grammar and words, utterly ignorant of the sense and grace of him." His mastery of English is something wonderful even in an age of masters, when the language was still a mother-tongue, and not a contrivance of pedants and grammariaus. He hidd a reverential sense of "our divine Homer's depth and gravity, which will not open itself to the curious ansterity of belaboring art, but only to the natural and most ingenious soul of our thrice-sacred Poesy." His task was as holy to him as a version of Scripture; he justifies the tear's of Achilles by those of Jesus, and the eloquence of his horse by that of Balaam's less noble animal. He does not always keep close to his original, but he sins no more, even in this, than any of his rivals. He is especially great in the similes. Here he rouses himself always, and if his enthusiasm sometimes lead him to heighten a little, or even to add ontright, he gives nis a pieture full of life and action, or of the grandeur and beauty of nature, as stirring to the fincy as his original. Of all who have attempter Homer, he has the topping merit of being inspired by him.

In the recent discussions of Homeric translation in Englancl, it has always been taken for granted that we had or could hare some adequate conception of Homer's metre. Lord Derby, in his Preface, plainly assumes this. But there can be no greater fallacy. No human ears, much less Greek ones, could have endured what, with our mechanical knowledge of the rerse, ignorance of the accent, and English pronunciation, we blandly accept for such music as Homer chanted. We have utterly lost the tume and cannot reprodnce it. Mr. Newman conjectures it to have been something like Tankee Doodle; Mr. Arnold is sure it was the English hexameter; and they are both partly right so far as we may trust our reasonable impressions; for, after all, an impression 
is all that we have. Cowper attempts to give the ring of the ápyupéo ß

"Dread-sounding, bounding on the silver bow,"

which only too fatally recalls the old Scottish dancing. tune, -

\section{"Amaisit I gaisit}

To see, led at command, A strampant and rampant Ferss lyon in his hand."

The attempt was in the right direction, however, for Homer, like Dante and Shakespeare, like all who really command language, seems fond of playing with assonances. No doubt the Homeric rerse consented at will to an eager rapidity, and no doubt also its gencral character is that of prolonged but unmonotonous roll. Everybody says it is like the long ridges of the sea, some orertopping their neighbors a little, each with an independent undulation of its crest, yet all driven by a common impulse, and breaking, not with the sudden snap of an unyielding material, but one after the other, with a stately curve, to slide back and mingle with those that follow. Chapman's measure has the disadrantage of an association with Sternhold and Hopkins, but it has the merit of length, and, where he is in the right mood, is free, spirited, and sonorous. Alove all, there is ererywhere the morement of life and passion in it. Chapman was a master of verse, making it hurry, linger, or stop short, to suit the meaning. Like all great versifiers he must be read with study, for the slightest change of accent loses the expression of an entire passage. His great fault as a translator is that he takes fire too casily and rums beyond his anthor. Perhaps he intensifies too much, though this be a fault on the right side; he certainly sometimes weakens the force of passages by crowding in particulars which Homer had wisely omitted, for 
Homer's simplicity is by no means mere simplicity of thought, nor, as it is often foolishly called, of nature. It is the simplicity of consummate art, the last achievement of poets and the invariable characteristic of the greatest among them. To Chapman's mind once warmed to its work, the words are only a mist, suggesting; while it hides, the divine form of the original image or thought ; and his imagination strives to body forth that, as he conceives it, in all its celestial proportions. Let us compare with Lord Derby's version, as the latest, a passage where Chapman merely intensifies (Book XIII., beginning at the 86th verse in Lord Derby, the $73 \mathrm{~d}$ of Chapman, and the 76th of Homer) :-

"Whom answered thus the son of Telamon:

'My hands, too, grasp with firmer hold the spear,

My spirit, like thine, is stirred; I feel my feet

Instinct with fiery life; nor should I fear

With Hector, son of Priam, in his might

Alone to meet, and grapple to the death.'"

Thus Lord Derby. Chapman renders :-

"This Telamonius thus received: "So, to my thoughts, my hands Burn with desire to toss my lince; each foot beneath me stands Bure on bright fire to use his speed; my heart is raised so high, That to encounter Hector's self I long insatiately.'"

There is no question which rersion is the more energetic. Is Lord Derby's nearer the original in being tamer? He has taken the "instinct with fiery life" from Chapman's hint. The original has simply "restless," or more familiarly "in a fidget." There is nothing about "grappling to the death," and "nor should I fear" is feeble where Chapnuan with his "long insatiately" is literal. We will give an example where Chap. man has amplified his original (Book XVI. v. 426; Derby, 494 ; Chapman, 405):-

"Down jumped he from his chariot; down leapt his foe as light; And as, on some far-looking rcck, a cast of vultures fight, 


\section{LIBRARY OF OLD AUTHORS.}

Fly on each other, strike and truss, part, meet, and then stick by, Tug both with crooked beaks and seres, cry, fight, and fight and cry, So fiercely fought these angry kings." *

Lord Derby's version is nearer :-

"He said, and from his car, accoutred, sprang;

Patroclus saw and he too leaped to earth.

As on a lofty rock, with angry screams,

Hook-beaked, with talons curred, two vultures fight,

So with loud shouts these two to battle rushed."

Chapman has made his first line out of two in Homer, but, granting the license, how rapid and springy is the verse! Lord Derby's "withs" are not agreeable, his "shouts" is an ill-chosen word for a comparison with vultures, "talons curved" is feeble, and his verse is, as usual, mainly built up of little blocks of four syllables each. "To battle" also is vague. With whom? Homer says that they rushed each at other. We shall not discuss how much license is loyal in a translator, but, as we think his chief aim should be to give a feeling of that life and spirit which makes the immortality of his original, and is the very breath in the nostrils of all poetry, he has a right to adapt himself to the genius of his own langunge. If he would do justice to his author, he must make up in one passage for his unavoidable shortcoming in another. He may here and there take for granted certain exigencies of verse in his original which he feels in his own case. Even Dante, who boasted that no word had erer mado him say what he did not wish, should have made an exception of rhyming ones, for thes sometimes, even in so abumdant a language as the Italian, have driven the most straightforward of poets inta an awkward détour.

We give one more passage from Chapman :-

* Chapman himself was evidently pleased with this, for he cites it as a sample of his rersion. 


\section{"And all in golden weeds}

He clothed himself; the golden scourge most elegantly dowe He took and mounted to his seat; and then the god begun To drive his chariot through the waves. From whirl-pits every way The whales exulted under him, and knew their king; the sea For joy did open, and his horse so swift and lightly flew The under axle-tree of brass no drop of water drew."

Here the first half is sluggish and inadequate, but what surging vigor, what tumult of the sea, what swiftness, in the last! Here is Lord Derby's attempt:-

"All clad in gold, the golden lash he grasped

Of curious work, and, mounting on his car,

Skimmed o'er the waves; from all the depths below

Gambolled around the monsters of the deep,

Acknowledging their king; the joyous sea

Parted her waves; swift flew the bounding steeds,

Nor was the brazen axle wet with spray."

Chapman here is truer to his master, and the motion is in the verse itself. Lord Derby's is description, and not picture. "Monsters of the deep" is an example of the hackneyed periphrases in which he abounds, like all men to whom language is a literary tradition, and not a living gift of the Muses. "Lash" is precisely the wrong word. Chapman is always great at sea. Here is another exam. ple from the Fourteenth Book :-

"And as, when with unwieldy waves the great sea forefeels winds That both ways murmur, and no way her certain current finds. But pants and swells confusedly, here goes, and there will stay, Till on it air casts one firm wind, and then it rolls away."

Observe how the somewhat ponderous movement of the first verse assists the meaning of the words.

He is great, too, in single phrases and lines:-

"And as, from top of some steep hill, the Lightener strips a cloud And lets a great sky out of IIearen, in whose delightsome light All prominent foreheads, forests, towers, and temples cheer the sight.'

(Book XVI. v. 286.)

The lion "lets his rough brows down so low they hido his eyes"; the flames "wrastle" in the woods; "rudo 
feet dim the day with a fog of dust ; "and so in a hundred other instances.

For an example of his more restrained vigor, take the speech of Sarpedon in the Twelfth Book of the lliad, and for poetic beauty, the whole story of Ulysses and Nausikaa in the Odyssey. It was here that Keats made himself Grecian and learned to versify.

Mr. Hooper has done his work of editing well. But he has sometimes misapprehended his author, and dis. torted his meaning by faulty punctuation. In one of the passages already cited, Mr. Hooper's text stands thus: "Lest I be prejudiced with opinion, to dissent, of ignorance, or singularity." All the commas which darken the sense should be removed. Chapman meant to say, "Lest I be condemned beforehand by people thinking I dissent out of ignorance or singularity." (Iliad Vol. I. p. 23.) So on the next page the want of a hyphen makes nonsense: "And saw the round coming [roundcoming] of this silver bow of our Phoebus," that is, the crescent coming to the full circle. In the translations, too, the pointing needs reformation now and then, but shows, on the whole, a praiseworthy fidelity. We will give a few examples of what we believe to be errors on the part of Mr. Hooper, who, by the way, is weakest on points which concern the language of Chapman's day. We follow the order of the text as most convenient.

"Bid" (Il. i.) is explained to mean "threaten, challenge," where "offer" would be the right word.

"And cast

The offal of all to the deep." (II. i. 309.)

Surely a slip of Chapman's pen. He must have intended to write "Of all the offal," a transversion common with him and needed here to avoid a punning jingle.

"So much I must affirm our power exceeds th' inlabitant." (II. ii. 110.) 
Mr. Hooper's note is "inhabiters, viz. of Troy." "Inhabitant " is an adjective agrecing with "power." Our power without exceeds that within.

"Yet all this time to stay,

Out of our judgments, for our end, and now to take our way

Without it were absurd and vile." (Il. ii. 257.)

A note on this passage tells us that "out of judgments" means " against our inclinations." It means simply " in accordance with our good judgment," just as we still say "out of his wisdom." Compare II. iii. 63,

"Hector, because thy sharp reproof is oul of juslice given, I take it well."

"And as Jove, brandishing a star which men a comet call, Hurls ont his curled hair abroad, that from his brand exlials A thousand sparks." (Il. iv. S5.)

Mr. Hooper's note is " "Which men a comet call' - so both the folios. Dr. Taylor has printed 'which man a comet calls.' This certainly suits the rhyme, but I adhere to Chapman's text." Both editors have misunderstood the passage. The fault is not in "call" but in "exhals," a clear misprint for " exhall," the spelling, as was common, being conformed to the visible rhyme. "That" means "so that" (a frequent Elizabethan construction) and "cxhall" is governed by "sparks." The meaning is, "As when Jove, brandishing a comet, hurls out its curled hair so that a thousand sparks exhale from its burning."

"The evicke skipping from the rock."

Mr. Hooper tells us, "It is doubtful what this word really is. Dr. Taylor suggests that it may probably mean the evict, or doomed one-but? It is possible Chapman meant to Anglicize the Greek aı ; or should

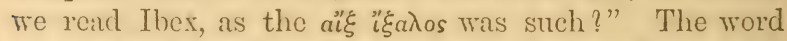
means the chemois, and is merely the English form of the French abiche. Dr. Taylor's reading would amaze us 
were we not familiar with the commentators on Shakespeare.

\section{"And now they out-ray to your fleet." (Il. v. 793.)}

"Out-ray-spread out in array; abbreviated from array. Dr. Taylor says 'rush out,' from the AngloSaxon 'rean,' to flow; but there seems no necessity for such an etymology." We should think not! Chapman, like Pope, made his first sketch from the French, and corrected it by the Greek. Those who would understand Chapman's English must allow for traces of his French guide here and there. This is one of them, perhaps. The word is etymologically unrelated to array. It is merely the old French oultreer, a derivative of ultra. It means "they pass beyond their gates even to your fleet." He had said just before that formerly "your foes durst not a foot address without their ports." The word occurs again Il. xxiii. 413.

" When none, though many kings put on, could make his vaunt, he led Tydides to renewed assault or issued first the dike." (II. viii. 217.)

"Tydides. - He led Tydides, i. e. Tydides he led. An unusual construction." Not in the least. The old printers or authors sometimes put a comma where some connecting particle was left out. We had just now an instance where one took the place of so. Here it supplies that. "None could make his vaunt that he led (that is, was before) Tydides." We still use the word in the same sense, as the "leading" horse in a race.

"And all did wilfully expect the silver-throned morn." (Il. viii. 497.) " Wilfully - willingly, anxiously." Wishfully, as elsewhere in Chapman.

"And as, upon a rich man's crop of barley or of wheat, Opposed for swiftness at their work, a sort of reapers sweat."

"Opposed - standing opposite to one another for expedition's sake." We hope MIr. Hooper understood his own 
note, for it baffles us utterly. The meaning is simply "pitted against each other to see which will reap most swiftly." In a note (Il. xi. 417) we are told that "the etymology [of lucern] seems uncertain." It is nothing more than a corruption of the old French lencerve (loupcervier).

"I would then make-in in deed and steep

My income in their bloods." (Il. xvii. 481.)

"Income - communication, or infusion, of courage from the Gods. The word in this sense Todd says was a favorite in Cromwell's time." A surprising note! Income here means nothing more than "onfall," as the context shows.

"To put the best in ure." (Il. xvii. 545.)

"Ure-use. Skimmer thinks it a contraction of usura. It is frequent in Chaucer. Todd gives examples from Hooker and L'Estrange." The word is common enough, but how Mr. Hooper could serionsly quote good old Skinner for such an etymology we cannot conceive. It does not mean "in use," but "to work," being merely the English form of en auvre, as "manure" is of manceurer.

"So troop-meal Troy pursued a while." (Il. xvii. 634.)

"Troop-meal - in troops, troop by troop. So piecemeal. To meal was to mingle, mix together; from the French mêler. . . . The reader would do well to consult Dr. Jamieson's excellent 'Dictionary of the Scottish Langruage' in roce 'mell.' " No doubt the reader might profit by consulting it under any other word beginning with M, and any of them would be as much to the purpose as mell. Troop-meal, like inch-meal, piece-meal, implies separation, not mingling, and is from a Teutonic root. Mrr. Hooper is always weak in his linguistic. In a note on Il. xviii. 144, he informs us that "To sterve is to die; and the sense of starve, with cold or hunger 
originated in the 17th century." We would it had! But we suspect that men had died of both these diseases earlier. What he should have said was that the restriction of meaning to dying with hunger was modern.

Il. xx. 239 we have "the God's" for " the Gods" " and a few lines below "Anchisiades" " for "Anchisiades's"; Il. xxi. 407 , "press'd " for " prest."

We had noted a considerable number of other slips, but we will mention only two more. "Treen broches" is explained to mean "branches of trees." (Hymn to Hermes, 227.) It means "wooden spits." In the Bacchus $(28,29) \mathrm{Mr}$. Hooper restores a corrupt reading which Mr. Singer (for a wonder) had set right. $\mathrm{He}$ prints, -

$$
\begin{aligned}
& \text { "Nay, which of all the Pow'r fully-divined } \\
& \text { Esteem ye him?" }
\end{aligned}
$$

Of course it should be powrerfully-divined, for otherwise we must read "Pow'rs." The five volumes need a very careful revision in their punctuation, and in another edition we should advise Mr. Hooper to strike out every note in which he has been tempted into etymology.

We come next to Mr. W. C. Hazlitt's edition of Lovelace. Three short pieces of Lovelace's have lived, and deserved to live: "To Lucasta from Prison," "To Lucasta on going to the Wars," and "The Grasshopper." They are graceful, airy, and nicely finished. The last especially is a charming poern, delicate in expression, and full of quaint fancy, which only in the latter half is strained to conceit. As the rerses of a gentleman they are among the best, though not of a very high order as poetry. He is to be classed with the lucky authors who, without great powers, have written one or two pieces so facile in thought and fortunate in phrase as to be carried lightly in the memory, poems in which analysis finds lit- 
tle, but which are charming in their frail completeness. This faculty of hitting on the precise lilt of thought and measure that shall catch the universal ear and sing themselves in everylody's memory, is a rare gift. We have heard many ingenious persons try to explain the cling of such a poem as "The Burial of Sir John Moore," and the result of all seemed to be, that there were certain verses that were good, not because of their goodness, but because one could not forget them. They have the great merit of being portable, and we have to carry so much luggage through life, that we should be thankful for what will pack easily and take up no room.

All that Lovelace wrote beside these three poems is utterly worthless, mere chaff from the threshing of his wits. Take out the four pages on which they are printed, and we have two hundred and eighty-nine left of the sorriest stuff that erer spoiled paper. The poems are obscure, without anything in them to reward perseverance, dull without being moral, and full of conceits so fir-fetched that we could wish the author no worse fate than to carry them back to where they came from. We are no enemies to what are commonly called conceits, but authors bear them, as heralds say, with a difference. And a terrible difference it is! With men like Earle, Dome, Fuller, Butler, Marvell, and even Quarles, conceit means wit; they would carve the merest cherrystone of thought in the quaintest and delicatest fashion. But with duller and more painful writers, such as Gascoyne, Marston, Felltham, and a score of others, even with cleverer ones like Waller, Crashawe, and Suckling, where they insisted on being fine, their wit is conceit. Difficulty without success is perhaps the least tolerable kind of writing. Mere stupidity is a natural failing; we skip and pardon. But the other is Dulness in a domino, that travesties its familiar figure, and lures us 
only to disappoint. These unhappy verses of Lovelace's had been dead and lapt in congenial lead these two hundred years; - what harm had they done Mr. Hazlitt that he should disinter them? There is no such disenchanter of peaceable reputations as one of these resurrectionmen of literature, who will not let mediocrities rest in the grave, where the kind sexton, Oblivion, had buried them, but dig them up to make a profit on their lead.

Of all Mr. Smith's editors, Mr. W. Carew Hazlitt is the worst. He is at times positively incredible, worse even than Mrr. Halliwell, and that is saying a good deal. Worthless as Lovelace's poems were, they should have been edited correctly, if edited at all. Even dulness and dirtiness have a right to fair play, and to be dull and dirty in their own way. Mr. Hazlitt has allowed all the misprints of the original (or by far the greater part of them) to stand, but he has ventured on many emendations of the text, and in every important instance has blundered, and that, too, even where the habitual practice of his author in the use of words might have led him right. The misapprehension shown in some of his notes is beyond the belief of any not familiar with the way in which old books are edited in England by the job. We have brought a heavy indictment, and we proceed to our proof, choosing only cases where there can be no dispute. We should premise that Mr. Hazlitt professes to have corrected the punetuation.

"And though he sees it full of wounds,

Cruel one, still he wounds it. (p. 34.)

Here the original reads, "Cruel still on," and the only correction needed was a comma after "crucl."

"And by the glorious light

Of both those stars, which of their spheres bereft,

Only the jelly "s left." (p. 41.)

The original has "of which," and rightly, for "their 
spheres bereft" is parenthetic, and the sense is "of which only the jelly 's left." Lovelace is speaking of the eyes of a mistress who has grown old, and his image, confused as it is, is based on the belief that stars shooting from their spheres fell to the earth as jellies, - a belief, by the way, still to be met with in New England.

Lovelace, describing a cow (and it is one of the few pretty passages in the volume), says, -

"She was the largest, goodliest beast

That ever mead or altar blest,

Round as her udder, and more white

Than is the Milky-Way in night." (p. 64.)

Mr. Hazlitt changes to "Round was her udder," thus making that white instead of the cow, as Lovelace intended. On the next page we read, -

" She takes her leave o' th' mournful neat, Who, by her toucht, now prizeth her life, Worthy alone the hollowed knife."

Compare Chapman (Iliads, xviii. 480) :-

"Slew all their white fleec'd sheep and neat."

The original was "prize their life," and the use of "neat" as a singular in this way is so uncommon, if not umprecedented, and the verse as corrected so halting, that we have no doubt Lovelace so wrote it. Of course "hollowed" should be "hallowed," though the broader pronunciation still lingers in our country pulpits.

"What need she other bait or charm

But look? or angle but her arm?" (p. 65.)

So the original, which Mrr. Hazlitt, missing the sense, has changed to "what hook or angle."

"Fly Joy on wings of Popinjays

To courts of fools where as your plays

Die laught at and forgot." (p.67.)

The original has "there." Read, - 
"Fly, Joy, on wings of popinjays

To courts of fools; there, as your plays,

Die," \&c.

"Where as," as then used, would make it the "plays" that were to die.

"As he Lucasta nam'd, a groan

Strangles the fainting passing tone;

But as she heard, Lucasta smiles,

Posses her round; she's slipt meanwhiles

Behind the blind of a thick bush." (p. 68.)

Mr. Hazlitt's note on "posses" could hardly be matched by any member of the posse comitatus taken at random :

"This word does not appear to have any rery exact meaning. See Halliwell's Dictionary of Archaic Words, art. Posse, and Worcester's Dict., ibid., \&c. The context here requires to turn sharply or quickly."

The "ibicl., \&c." is delightful; in other words, "find out the meaning of posse for yourself." Though dark to Mr. Hazlitt, the word has not the least obscurity in it. It is only another form of push, nearer the French pousser, from Latin pulsare, and "the context here requires" nothing more than that an editor should read a poem if he wish to understand it. The plain meaning is, -

"But, as she heard Lucasta, smiles

Possess her round."

That is, when she heard the name Lucasta, - for thus far in the poem she has passed under the psendonyme of Amarantha. "Possess her round" is awkward, but mildly so for Lovelace, who also spells " commandress" in the same way with a single $s$. Process is spelt prosses in the report of those who absented themselves from Church in Stratford.

"O thou, that swing'st upon the waving eare, Of some well-filled oaten beard." (p. 94.) 
Mr. Hazlitt, for some inscrutable reason, has changed "haire" to "eare" in the first line, preferring the car of a beard to its hair!

Mr. Hazlitt prints, -

"Poor verdant foole! and now green ice, thy joys

Large and as lasting as thy peirch of grass,.

Bid us lay in 'gainst winter raine and poize

Their flouds with an o'erflowing glasse." (p. 95.)

Surely we should read :-

"Poor verdant foole and now green ice, thy joys,

Large and as lasting as thy perch of grass, Bid," \&c.

i. e. "Poor fool now frozen, the shortness of thy joys, who mad'st no provision against winter, warns us to do otherwise."

"The radiant gemme was brightly set

In as divine a carkanet;

Of which the clearer was not knowne

Her minde or her complexion." (p. 101.)

The original reads rightly "for which," dc., and, the passage being rightly pointed, we have, -

"For which the clearer was not known,

Her mind or her complexion."

Of course "complexion" had not its present limited meaning.

\section{Shall bow itself." (p. 107.)}

". . . my future daring bayes

"We should read themselves," says Mr. Hazlitt's note authoritatively. Of course a noun ending in $s$ is plural! Not so fast. In spite of the dictionaries, bays was often used in the singular.

"Do plant a sprig of eypress, not of bays,"

says Robert Randolph in verses prefixed to his brother's poems ; and Felltham in "Jonsonus Virbius,"

"A greener bays shall crown Ben Jonson's name."

But we will cite Mr. Bayes himself :- 
"And, where he took it up, resigns the bays."

"But we (defend us!) are divine,

[Not] fermale, but madam born, and come

From a right-honorable wombe." (p. 115.)

Here Mr. Hazlitt has ruined both sense and metre by his unhappy " not." We should read "Female, but madam-born," meaning clearly enough "we are women, it is true, but of another race."

"In every hand [let] a cup be found

That from all hearts a health may sound." (p. 121.)

Vrong again, and the inserted "let" ruinous to the meas. ure. Is it possible that $\mathrm{Mr}$. Hazlitt does not understand so common an English construction as this?

"First told thee into th' ayre, then to the ground." (p. 141.)

Mr. Hazlitt inserts the "to," which is not in the original, from another version. Lovelace wrote "ayër." We have noted two other cases (pp. 203 and 248) where he makes the word a dissyllable. On the same page we have "shewe's" changed to "shew" because Mr. Hazlitt did not know it meant "show us" and not "shows." On page 170, "their" is substituted for "her," which refers to Lucasta, and could refer to nothing else.

Mr. Hazlitt changes "quarrels the student Mercury" to "quarrels with," not knowing that quarrels was once used as a transitive verb. (p. 189.)

Wherever he chances to notice it, Mr. Hazlitt changes the verb following two or more nouns connected by an "and" from singular to plural. For instance:-

"You, sir, alone, fame, and all conquering rhyme

File the set teeth," \&c. (p. 224.)

for "files." Lovelace commonly writes so ; - on p. 181, where it escaped Mr. Hazlitt's grammatical eye, we find, -

"But broken faith, and th' cause of it,

All damning gold, was damned to the pit." 
Indeed, it was usual with writers of that day. Milton in one of his sonnets has, -

"Thy worth and skill exempts thee from the throng," and Leigh Hunt, for the sake of the archaism, in one of his, "Patience and Gentleness is power."

Weariness, and not want of matter, compels us to desist from further examples of Mr. Hazlitt's emendations. But we must also give a few specimens of his notes, and of the care with which he has corrected the punctuation.

In a note on "flutes of canary" (p. 76) too long to quote, Mr. Hazlitt, after citing the glossary of Nares (edition of 1859 , by Wright and Halliwell, a very careless book, to speak mildly), in which flute is conjectured to mean cask, says that he is not satisfied, but adds, "I suspect that a flute of canary was so called from the cask haring several vent-holes." But flute means simply a tall gliass. Lassel, describing the glass-making at Murano, says, "For the IIigh Dutch they have high gliasses called Flutes, a full yard long." So in Dryden's Sir Martin Mfar-all, "bring two flute-glasses and some stools, ho! We 'll have the ladies' health." The origin of the word, though doubtful, is probably nearer to flood than flute. But conceive of two gentlemen, members of one knows not how many learned societies, like Messrs. Wright and Halliwell, pretending to edit Nares, when they query a word which they could have found in any French or German dictionary!

On page 93 we have, -

"Hayle, holy cold! chaste temper, hayle! the fire Raved o'er my purer thoughts I feel t' expire."

Mr. Hazlitt ammotates thus: "licuv'd secms here to be equivalent to reav'd or bereav'd. Perhaps the correct reading may be 'reav'd.' See Worcester's Dictionary, art. $R A$ ra, where Menage's supposition of affinity be- 
tween rave and bereave is perhaps a little too slightingly treated."

The meaning of Lovelace was, "the fire that raved." But what Mr. Hazlitt would make with "reaved o'er my purer thoughts," we camnot conceive. On the whole, we think he must have written the note merely to make his surprising glossological suggestion. All that IVorcester does for the etymology, by the way, is to cite Richardson, no safe guide.

"Where now one so so spatters, t'other: no!" (p. 112.)

The comma in this verse has, of course, no right there, but Mr. Hazlitt leaves the whole passage so corrupt that we cannot spend time in disinfecting it. We quote it only for the sake of his note on "so so." It is marvellous.

"An exclamation of approval when an actor made a hit. The corruption seems to be somewhat akin to the Italian, 'si, si,' a corruption of 'sia, sia.'"

That the editor of an English poet need not understand Italian we may grant, but that he should not know the meaning of a phrase so common in his own langmage as so-so is intolerable. Lovelace has been saying that a certain play might have gained applause under certain circumstances, but that ererybody calls it so-so, - something very different from "an exclamation of approval," one should say. The phrase answers exactly to the Italian cosi cosi, while sì (not si) is derived from sic, and is analogous with the affirmative use of the German so and the Yankee jes' so.

"Oh, how he hast'ned death, burnt to be fryed!" (p. 141.)

The note on fryed is, -

"I. e. freed. Free and freed were sometimes pronounced like firy and fryed; for Lord North, in his Forest of Varieties, 1645, has these lines:- 
- Birds that long have iived free,

Caught and cag'd, but pine and die.'

Here evidently free is intencled to rhyme with die."

"Evidently!" An instance of the unsafeness of rhyme as a guide to pronunciation. It was die that had the sound of dee, as everybody (but Mr. Hazlitt) knows. Lorelace himself rhymes die and she on p. 269. But what shall we say to our editor's not knowing that fry was used formerly where we should say burn? Lovers used to fry with love, whereas now they have got out of the frying-pan into the fire. In this case a martyr is represented as burning (i. e. longing) to be fried (i. e. burned).

"Her beams ne'er shed or change like th' hair of day." (p. 224.)

\section{Mr. Hazlitt's note is, -}

"ITair is here user in what has become quite an obsolete sense. The meaning is outwarl form, nature, or character. The word used to be by no means umcommon; but it is now, as was before remarked, out of fashion; and indeed I do not think that it is found even in any old writer used exactly in the way in which Lovelace has employed it."

Te should think not, as Mr. Hazlitt understands it ! Did he nerer hear of the golden hair of Apollo, - of the intonsum Cynthium? Don Quixote was a better scholar where he speaks of las doradas hebras de sus hermosos cabellos. But hair never meant what Mr. Hazlitt says it does, even when used as he supposes it to be here. It had nothing to do with "ontward form, nature, or character," but had a meaning much nearer what we express by temperament, which its color was and is thought to indicate.

On p. 232 "wilel ink" is explained to mean "unvefined." It is a mere misprint for "vild."

Page 2:37, Mr. Hazlitt, explaining an illusion of Lovelace to the "east and rest" in speaking of George 
Sandys, mentions Sandys's Oriental travels, but seems not to know that he translated Ovid in Virginia.

Pages 251, 252:-

"And as that soldier" conquest doubted not,

Who but one splinter had of Castriot,

But would assault ev'n death, so strongly charmed,

And naked oppose rocks, with this bone armed."

Mr. Hazlitt reads his for this in the last verse, and his note on "bone" is :-

"And he found a new jawbone of an ass, and put forth his hand and took it, and slew a thousand men therewith. (Judges xv. 15.) "

Could the furce of "editing" go further? To make a "splinter of Castriot" an ass's jawbone is a little too bad. We refer Mr. Hazlitt to "The Life of George Castriot, King of Epirus and Albania," \&ce., drc., (Edinburgh, 1753$,$) p. 32, for an explanation of this profound diffi-$ culty. He will there find that the Turkish soldiers wore relics of Scanderbeg as charms.

Perhaps Mr. Hazlitt's most astounding note is on the word pickear. (p. 203.)

"So within shot she doth pickear,

Now gall's [galls] the flank and now the rear."

"In the sense in which it is here used this word seems to be peculiar to Lovelace. To pickear, or pickeer, means to skirmish." And, pray, what other possible meaning can it have here?

Of his corrections of the press we will correct a few samples.

Page 34, for "Love nee're his standard," read " neere." Page 82, for "fall too," read "fall to" (or, as we ought to print such words, "fall-to"). Page 83, for "star-made firmament," read "star, made firmament." Page 161, for "To look their enemies in their hearse," read, both for sense and metre, into. Page 176, for "the gods have 
kneeled," read had. Page 182, for "In beds they tumbled off their own," read of. Page 18t, for " in mine one monument I lie," read owne. Page 212, for "Deucalion's bluckflung stone," read "backflung." Of the punctuation we shall give but one specimen, and that a fair average one :-

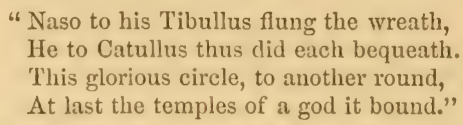

Our readers over ten years of age will easily correct this for themselves.

Time brings to obscure authors* an odd kind of reparation, an immortality, not of love and interest and admiration, but of curiosity merely. In proportion as their language was uncouth, provincial, or even barbarous, their value becomes the greater. $\Lambda$ book of which only a single copy escaped its natural enemies, the pastry-cook and trunk-maker, may contain one word that makes daylight in some dark passage of a great author, and its name shall accordingly live forever in a note. Is not, then, a scholiastic athanasy better than none? And if literary vanity survive death, or even worse, as Brunetto Latini's made him insensible for a moment to the rain of fire and the burning sand, the authors of such books as are not properly literature may still comfort themselves with a non omnis moriar, laying a mournful emphasis on the adjective, and feeling that they have not lived wholly in vain while they share with the dodo a fragmentary continuance on earth. To be sure, the immortality, such as it is, belongs less to themselves than to the famous mon they help to illustrate. If they escape oblivion, it is by a back door, as it were, and they

* Early Popular Poetry. Edited by W. Çarew Hazlitt. 
survive only in fine print at the page's foot. At the banquet of fame they sit below the salt. After all, perhaps, the next best thing to being famous or infamous is to be utterly forgotten, for this also is to achieve a kind of definite result by living. To hang on the perilous edge of immortality by the nails, liable at any moment to drop into the fathomless ooze of oblivion, is at best a questionable beatitude. And yet sometimes the merest barnacles that have attached themselves to the stately keels of Dante or Shakespeare or Milton have an interest of their own by letting us know in what remote waters those hardy navigators went a pearl-fishing. Has not Mr. Dyce traced Shakespeare's "dusty death" to Anthony Copley, and Milton's "back resounded Death!" to Abraham Fraunce? Nay, is it not Bernard de Ventadour's lark that sings forever in the diviner air of Dante's Paradise?
"Quan vey laudeta mover
De joi sas alas contra'l rai, Que s'oblida e s laissa cazer
Per la doussor qu 'al cor li 'n vai."
"Qual lodoletta che in aere si spazia, Prima cantando, e poi tace contenta Dell' ultima dolcezza che la sazia."

We are not sure that Bernard's "Que s'oblida e s laissa cazer" is not sweeter than Dante's "tace contenta," but it was plainly the doussor that gave its cue to the greater poet's memory, and he has improved on it with that exquisite ultima, as his master Virgil sometimes did on Homer.

But authors whose interest for us is mainly bibliographic belong rather in such collections as Mr. Allibone's. As literature they are oppressive; as items of literary history they find their place in that rast list which records not only those named for promotion, but also the killed, wounded, and missing in the Battle of 
the Books. There our hearts are touched with something of the same rague pathos that dims the eye in some deserted graveyard. The brief span of our earthly immortalities is brought home to us as nowhere else. What a necrology of notability! How many a controversialist, terrible in his day, how many a rising genius that somehow stuck on the horizon, how many a withering satirist, lies here shrunk all away to the tombstone brevity of a name and date! Think of the aspirations, the dreams, the hopes, the toil, the confidence (of himself and wife) in an impartial and generous posterity, and then read "Smith J. [ohn?] 1713-1784 (?). The Vision of Immortality, an Epique Poem in twelve books, 1740 , 4to. See Lownules." The time of his own death less certain than that of his poem, (which we may fix pretty safely in 1740, and the only posterity that took any interest in him the indefatigable compiler to whom a name was valual,le in proportion as it was obscure. Well, to have even ss much as your title-page read after it has rumded the corner of its first century, and to cnjoy a posthumous pullic of one is better than nothing. This is the true Valhallia of Mediocrity, the Libro dione of the onymi-anonymi, of the never-named authors who exist only in name. Parson Adams would be here had he found a printer for his sermons, and Mr. Primrose, if a copy existed of his tracts on monogamy. Papyrorcetes junior will turn here with justifiable pride to the name of his respectable progenitor. Here we are secure of perpetuity at least, if of nothing better, and are sons though we may not be heirs, of fame. Here is a handy and inexpensive substitute for the waxen imagines of the Roman patriciate, for those must have been inconvenient to pack on a change of lodgings, liable to melt in warm wenther (even the elder Brutus himself might soften in the dog-days) and not readily salable 
unless to some novus homo willing to buy a set of ancestors ready-made, as some of our own enthusiasts in genealogy are said to order a family-tree from the heraldic nurseryman, skilled to imp a slip of Scroggins on a stock of De Vere or Montmorenci. Fame, it should seem, like electricity, is both positive and negative, and if a writer must be Somebody to make himself of permanent interest to the world at large, he must not less be Nobody to have his namelessness embalmed by M. Gnérard. The benignity of Providence is nowhere more clearly to be seen than in its compensations. As there is a large class of men madly desirous to decipher cuneiform and other inscriptions, simply because of their illegibility, so there is another class driven by a like irresistible instinct to the reprinting of unreadable books. Whether these have even a philologic value for us depends on the accuracy and learning bestowed upon them by the editor.

For there is scarcely any rubbish-heap of literature out of which something precious may not be raked by the diligent explorer, and the late Mr. Dyce (since Gifford, the best editor of our literature of the Tudor and Jacobean periods) might well be called the Golden Dustman, so many were the precious trifles sifted out by his intelligent industry. It would not be easy to name any work more thoroughly done than his edition of Skelton. He was not a philologist in the stricter sense, but no man had such a commonplace-book as he, or knew so exactly the meaning with which words were used during the period he did so much to illustrate. Elegant scholar ship is not often, as in him, patient of drudgery and conseientious in painstaking. Between such a man and Mr. Carew Hazlitt the contrast is by no means agreealle. The one was not more distinguished by modest accuracy than the other is by the rash conceit of that half-knowl- 
edge which is more mischievous in an editor than downright ignorance. This language is strong because it is true, though we should not have felt called upon to use it but for the vulgar flippancy with which Mr. Hazlitt alludes depreciatingly to the labors of his predecessors, - to such men as Ritson, Utterson, Wright, and Sir Frederick Madden, his superiors in everything that goes to the making of a good editur. Niost of them are now dead and nailed in their chests, and it is not for us to forget the great debt we owe to them, and others like them, who first opened paths for us through the tangled wilderness of our early literature. A modern editor, with his ready-made helps of glossary, annotation, and comment, should think rather of the difficulties than the defects of these pioneers.

How different is Mrr. Hazlitt's spirit from that of the thorough and therefore modest scholar! In the Preface to his Altenglische Sprathroben, Miitzner says of an editor, das Beste was er ist verdanlit er Andern, an accidental pentameter that might seem to have dropped out of Nathan der Wreise. Mr. Hazlitt would profit much by getting some friend to translate for him the whole paragraph in which it occurs.

We see it amounced that Mr. Hazlitt is to superintend a new edition of Warton's History of English Poetry, and are pained to think of the treatment that robust scholar and genial poet is likcly to receive at the hands of an editor without taste, discrimination, or learning. Of his taste a single specimen may suffice. He tells us that "in an artistic and constructive point of view, the Mrylner of Alington is superior to its predecessor," that predecessor being Chaucer's Reve's Tale, which, with his usual inaccuracy, he assigns to the Miller! Of his discrimination we have a sufficient test in the verses he has fathered upon Herrick in a late 
edition of the most graceful of our lyric poets. Perhaps discrimination is not, after all, the right word, for we have sometimes seen cause to doubt whether Mr. Hazlitt ever reads carefully the very documents he prints. For example, in the Biographical Notice prefixed to the Herrick he says (p. xvii) : "Mr. W. Perry Herrick has plausibly suggested that the payments made by Sir William to his nephew were simply on account of the fortune which belonged to Robert in right of his father, and which his uncle held in trust ; this was about $£ 400$; and I think from allusions in the letters printed elsewhere that this view may be the correct one." May be ! The poet says expressly, "I entreat you out of my little possession to deliver to this bearer the customarye $£ 10$, without which I cannot meate [?] my ioyrney." The words we have italicized are conclusive. By the way, Mr. Hazlitt's wise-looking query after "meate" is conclusive also as to his fitness for editorship. Did he never hear of the familiar phrase "to meet the expense"? If so trifling a misspelling can mystify him, what must be the condition of his mind in face of the more than Protean travesties which words underwent before they were uniformed by Johnson and Walker? Mr. Hazlitt's mind, to be sure, like the wind Cecias, always finds its own fog. In another of Herrick's letters we find, "For what her monie can be effected $(s i c)$ when there is diuision 'twixt the hart and hand?" "Her monie" of course means harmonie, and effected is therefore right. What Mr. Hazlitt may have meant by his " (sic)" it were idle to inquire.

We have already had occasion to examine some of Mr. Hazlitt's work, and we are sorry to say that in the four volumes before us we find no reason for changing our opinion of his utter disqualification for the duties of editorship. He seldom clears up a real difficulty (never, 
we might say, with lights of his own), he frequently creates a darkness where none was before, and the pecu. liar bumptiousness of his incapacity makes it particularly offensive. We shall bring a few instances in proof of what we assert, our only cmbarrassment being in the superabundance of our material. In the Introduction to the second volume of his collection, Mr. Hazlitt speaks of "the utter want of common care on the part of previous editors of our old poetry." Such orersights as he has remarked upon in his notes are commonly errors of the press, a point on which Mr. Hazlitt, of all men, should have been charitable, for his own volumes are full of them. We call his attention to one such which is rather amusing. In his "additional notes" we find "line 77 , wylle. Strike out the note upon this word; but the explanation is correct. Be wroght was a misprint, however, for lee wroghte" The crror occurs in a citation of three lines in which lother is still left for tother. The original note affords us so good an example of Mr. Hazlitt's style of editing as to be worth preserving. In the "Kyng and the Hermit" we read, -

"He ne wyst w[h]ere that he was Ne out of the forest for to passe, And thus he rode all wylle."

And here is Mr. Hazlitt's amnotation on the word wylle:-

" $i$. e. evil. In a MIS. of the Tale of the Basyn, supposed by Mr. Wright, who edited it in 1836, to be written in the Salopian dialect, are the following lines:-

'The lother hade litull thoght,

Off husbandry cowth he noght,

But alle his wyves will be wroght.'" (Vol. I. p. 16.)

It is plain that he supposed will, in this very simple passage, to mean evil! This he would seem to rectify, but at the same time takes care to tell us that "the expla. 
nation [of wylle] is correct." He is willing to give up one blunder, if only he may have one left to comfort himself withal! Wylle is simply a rhyming fetch for wild, and the passage means that the king rode at random. The use of vilul with this meaning is still common in such phrases as "he struck wild." In "Havelok" we find it in the nearly related sense of being at a loss, knowing not what to do:-

"To lincolne barfot he yede

Hwan he kam ther he was ful wil,

Ne hauede he no frend to gangen til."

All voylle, in short, means the kind of editing that is likely to be done by a gentleman who picks up his misinformation as he goes along. We would hint that a person must know something before he can use even a glossary with safety.

In the "King and the Barker," when the tanner finds out that it is the king whom he has been treating so familiarly, and falls upon his knces, Mr. Hazlitt prints,

"He had no meynde of hes hode, nor cape, ne radell,"

and subjoins the following note: "Radell, or raddle, signifies a side of a cart; but here, apparently, stands for the cart itself. Ritson printed ner adell." Mr. Hazlitt's explanation of raddle, which he got from Halliwell, is incorrect. The word, as its derivation (from 0 . F. rastel) implies, means the side or end of a hay-cart, in which the uprights are set like the teeth of a rake. But what has a cart to do here? There is perhaps a touch of what an editor of old doggerel would benignantly call humor, in the tanner's forgetfulness of his raiment, but the cart is as little to the purpose as one of $\mathrm{Mr}$. Hazlitt's own notes. The tammer was on horseback, as the roads of the period required that he should be, and good old Ritson was plainly on the right track in his reading, though his text was muddled by a misprint. 
As it was, he got one word right, and so far has the advantage of Mrr. Hazlitt. The true reading is, of course, ner a dell, never a deal, not a whit. The very phrase occurs in another poem which Mr. Hazlitt has reprinted in his collection, -

"For never a dell

He wyll me love agayne." (Vol. III. p. 2.)

That adell was a misprint in Ritson is proved by the fact that the word does not appear in his glossary. If we were to bring Mr. Hazlitt to book for his misprints! In the poem we have just quoted he gravely prints, -

\section{"Matter in dede,}

My sides did blede,"

for "mother, indede," "through ryght wysenes" for "though ryghtwisencs," "with man vnkynde" for "sith man vnkynde," "ye knowe a parte" for "ye knowe aperte," "here in " for "herein," all of which make nonsense, and all come within the first one hundred and fifty lines, and those of the shortest, mostly of four syllables each. Perhaps they rather prove ignorance than want of eare. One blunder falling within the same limits we have reserved for special comment, because it affords a good example of Mr. Hazlitt's style of editing :-

"Your herte souerayne

Clouen in twayne

By longes the blynde." (Vol. III. p. 7.)

Here the uninstructed reader would be as completely in the dark as to what longes meant as the editor plainly was himself. The old rhymer no doubt wrote Longis, meaning thereby Longinus, a personage familiar enough, one should think, to any reader of medieval poetry. Arr. Hazlitt absolves himself for not haring supplied a glossary by the plea that none is needed by the class of readers for whom his volumes are intended. But this will hardly seem a valid excuse for a gentleman who 
often goes out of his way to explain in his notes such simple matters as that "shape " means "form," and that "Johan of the golden mouthe" means "St. Chrysostom," which, indeed, it does not, any more than Johamnes Baptista means St. Baptist. We will supply Mrr. Hazlitt with an illustration of the passage from Bekker's Fercbras, the more willingly as it may direct his attention to a shining example of how an old poem should be edited :-

\footnotetext{
" en la crotz vos pendero li fals Iuzieu truan, can Longis vos ferie de sa lansa trencan: el non avia vist en trastot son vivan;

lo sanc li venc per l'asta entro al punh colan;

e [el] toquet ne sos huelhs si vic el mantenan."
}

Mr. Inazlitt, to be sure (who prints sang parlez for sanz parler) (Vol. I. p. 265), will not be able to form any notion of what these verses mean, but perhaps he will be able to draw an inference from the capital $L$ that longes is a proper name. The word truan at the end of the first verse of our citation may also suggest to him that truant is not quite so satisfactory an explanation of the word tren'ät as he seems to think. (Vol. IV. p. 24, note.) In deference to Mr. Hazlitt's presumed familiarity with an author sometimes quoted by him in his notes, we will point him to another illustration :-

"Ac ther cam forth a knyght,

With a kene spere $y$-grounde

Highte Longeus, as the lettre telleth,

And longe hadde lore his sighte."

Piers Ploughman, Wright, p. 374.

Mr. Hazlitt shows to peculiar advantage where old French is in question. Upon the word Osyll he favors us with the following note: "The blackloird. In East Cornwall ozell is used to signify the windpipe, and thence the bird may have had its name, as Mr. Couch has suggested to me." (Vol. II. p. 25.) Of course the black- 
bird, alone among fowls, is distinguished by a windpipe! The name is merely another form of 0 . F. oisil, and was usurped naturally enough by one of the commonest birds, just as pajaro (L. passer) in Spanish, by a similar process in the opposite direction, came to mean bird in general. On the very next page he speaks of "the Romance which is vulgarly entitled Lybeaus Disconus, i. e. Le Bean Disconnu." If he had corrected Disconus to Desconus, all had been well; but Disconnu neither is nor ever was French at all. Where there is blundering to be done, one stone often serves Mr. Hazlitt for tro birds. Ly beaus Disconus is perfectly correct old French, and another form of the adjective (lius) perhaps explains the sound we give to the first syllable of beauty and Beanfort. A barrister at law, as Mr. Hazlitt is, may not be called on to know anything about old English or modern French, but we might fairiy expect him to have at least a smattering of Law French! In rolume fourth, page 129, a goodman trying his wife,

"Bad her take the pot that sod ouer the fire And set it abooue vpon the astire."

Mr. Hazlitt's note upon astire is "hearth, i. q. astre." Knowing that the modern French was âtre, he too rashly inferred a form which never existed except in Italian. The old French word is aistre or estre, but Mr. Hazlitt, as usual, prefers something that is neither old French nor new. Wo do not pretend to know what astire means, but a hearth that should be abooue the pot seething over the fire would be unusual, to say the least, in our semi-civilized country.

In the "Lyfe of Roberte the Deuill" (Vol. I. p. 232), Mr. Hazlitt twice makes a knight sentre his lance, and tells us in a note that the "Et. 1798 has fentered," a very easy misprint for the right word feutered. What Mr. Hazlitt supposed to be the meaning of sentre he has 
not vouchsafed to tell us. Fautre (sometimes faltre or feutre) means in old French the rest of a lance. Thus in the Roman du Renart (26517),

"Et mist sa lance sor le fautre."

But it also meant a peculiar lind of rest. In Sir F. Madden's edition of Gawayne (to which Mr. Hazlitt refers occasionally) we read,

"They feutred their lances, these knyghtes good";

and in the same editor's "William and the Werwolf,"

"With sper festened in feuter, him for to spille."

In a note on the latter passage Sir F. Madden says, "There seems no reason, however, why it [feuter] should not mean the rest attached to the armour." But Roquefort was certainly right in calling it a "garniture d'une selle pour tenir la lance." A spear fastened to the saddle gave more deadly weight to the blow. The "him for to spille" implies this. So in "Morlin" (E. E. Text Soc., p. 488): "Than thei toke speres grete and rude, and putte hom in fewtre, and that is the grettest crewelte that oon may do, ffor turnement oweth to be with-oute felonye, and they mered to smyte hem as in mortall werre." The context shows that the fewtre turned sport into earnest. A citation in Raynouard's Lexique Roman (though wrongly explained by him) directed us to a passage which proves that this particular kind of rest for the lance was attached to the saddle, in order to render the blow heavier :-

"Lances à [lege as] arçons afeutrées Pour plus de dures colces rendre."

Branche des Royaux Lignages, 4514, 4515.

Mr. Hazlitt, as we have said, lets no occasion slip to insinuate the inaccuracy and carelessness of his predecessors. The long and useful career of Mr. Wright, 
who, if he had given us nothing more than his excel. lent edition of "Piers Ploughman" and the volume of "Ancient Vocabularies," would have deserved the gratitude of all lovers of our literature or students of our language, does not save him from the severe justice of Mr. Hazlitt, nor is the name of Wirton too venerable to be coupled with a derogatory imuendo. Mr. Wright needs no plea in abatement from us, and a mischance of Mr. Hazlitt's own has comically avenged Warton. The word prayer, it seems, had somehow substituted itself for prayse in a citation by Warton of the title of the "Schole-House of Women." Mr. Hazlitt thereupon takes occasion to charge him with often "speaking at random," and after suggesting that it might have been the blunder of a copyist, adds, "or it is by no means impossible that Warton himself, having been allowed to inspect the production, was guilty of this oversight." (Vol. IV. p. 98.) Now, on the three hundred and eighteenth page of the same volume, Mr. Hazlitt has allowed the following couplet to escape his conseientious attention :-

"Next, that no gallant should not ought suppose That prayers and glory doth consist in cloathes."

Lege, nostro periculo, prarse! Were dear old Tom still on earth, he might light his pipe checrfully with any one of A.r. Hazlitt's pryes, secure that in so doing he was consuming a brace of blunders at the least. The worl prom is an mlucky one for Mr. Hazlitt. In the "Knigght and his Wyfe" (Vol. II. p. 18) he prints:-

"And sayd, Syre, I rede we make In this chapel oure prayers, That God us kepe both in ferrus.'

Why did not Mr. Hazlitt, who explains so many things that everybody knows, give us a note upon in ferrus? It would have matched his almirable elucidation of 
waygose, which we shall notice presently. Is it not barcly possible that the MS. may have read prayere and in fere? Prayere occurs two verses further on, and not as a rhyme.

Mr. Hazlitt even sets Sir Frederick Madden right on a question of Old English grammar, telling him superciliously that can, with an infinitive, in such phrases as he can go, is used not "to denote a past tense, but an imperfect tense." By past we suppose him to mean perfect. But even if an imperfect tense were not a past one, we can show by a passage in one of the poems in this very collection that $c a n$, in the phrases referred to, sometimes not only denotes a past but a perfect tense :-

"And thorow that worde y felle in pryde;

As the aungelle can of hevyn glyde, And with the tywnkling $*$ of an eye God for-dud alle that maystrye And so hath he done for my gylte."

Now the angel here is Lucifer, and can of hevyn glyde means simply fell from heruen, not was falling. It is in the same tense as for-dud in the next line. The fall of the angels is surely a fait accompli. In the last line, by the way, Mr. Hazlitt changes "my for" to "for my," and wrongly, the my agreeing with maystrye understood. In modern English we should use mine in the same way. But Sir Frederick Madden can take care of himself.

We have less patience with Mr. Hazlitt's impertinence to Ritson, a man of ample reading and excellent taste in selection, and who, real scholar as he was, always drew from original sources. The have a foilte for Ritson with his oddities of spelling, his acerb humor, his unconsciously depreciatory mister Tyrwhitts and mister Bryants, and his obstinate disbelief in Doctor Percy's

* The careless Ritson would have printed this trcynkling. 
folio manuscript. Above all, he was a most conscientious editor, and an accurate one so far as was possilile with the lights of that day. Mr. Hazlitt has reprinted two poems, "The Squyr of Low Degre" and "The Knight of Curtesy," which had already been edited by Ritson. The former of these has passiges that are unsurpassed in simple beauty by anything in our earlier poetry. The author of it was a good versifier, and Ritson, though he corrected sume glaring errors, did not deal so trenchantly with verses manifestly lamed by the copyist as perhaps an editor should.* Mr. Hazlitt says of Ritson's text, that "it offers more than an hundred departures from the original," and of the "Knight of Courtesy," that "Ritson's text is by no means accurate." Now Mr. Hazlitt has adopted nearly all of Ritson's emendations, without giving the least hint of it. On the contrary, in sume five or six instances, he gives the original reading in a foot-note with an "old ed. has " so and so, thus leaving the reader to infer that the corrections were his own. Where he has not followed Ritson, he has almost uniformly blundered, and that through sheer ignorance. For example, he prints,

\section{"Alas! it tourned to wroth her heyle,"}

where Ritson had sulnstituted wrotherhey'e. The measure shows that Ritson was right. Wroth her heyle, moreover, is nonsense. It should have been wrother her heyle at any rate, but the text is far too modern to admit of that archaic form. In the "Delnate of the Body and the Soul " (Mätzner's A. E. Sprachproben, 103) we have,

* For example: -

"And in the arber was a tre

A fairer in the world might none be,"

should certainly read,

"None fairer in the world might be." 
"Why schope thou me to wrother-hele," and in "Dame Siris" (Ibid., 110),

"To goder hele ever came thou hider."

Mr. Hazlitt prints,

"For yf it may be found in thee

- That thou them [de] fame for enuyte."

The emendation [de] is Ritson's, and is probably right, though it would require, for the metre's sake, the elision of that at the beginning of the verse. But what is cnuyte? Ritson reads enmyte, which is, of course, the true reading. Mr. Hazlitt prints (as usual either without apprehending or withont regarding the sense),

"With browes bent and eyes full mery,"

where Ritson has brent, and gives parallel passages in his note on the word. Mr. Hazlitt gives us

"To here the bugles there yblow, With their bugles in that place,"

though Ritson had made the proper correction to begles. Mr. Hazlitt, with ludicrous nonchalance, allows the Squire to press into the throng

"With a bastard large and longe,"

and that with the right word (baslarde) staring him in the face from Ritson's text. We wonder he did not give us an illustrative quotation from Falconbridge! Both editors have allowed some gross errors to escape, such as "come not" for "come" (v. 425) ; "so leue he be" for "ye be" (v. 593) ; "vnto her chambre" for "vnto your" (v. 993); but in general Ritson's is the better and more intelligent text of the two. In the "Knight of Curtesy," Mr. Hazlitt has followed Ritson's text almost literatim. Indeed, it is demonstrable that he gave it to his printers as copy to set up from. The proof is this: Ritson has accented a few words ending in tè. 
Generally he uses the grave accent, but now and then the acute. Mr. Hazlitt's text follows all these variations exactly. The main difference between the two is that Ritson prints the first personal pronoun $i$, and Mr. Hazlitt, I. Ritson is probably right; for in the "Scholehouse of Women" (vv. 537, 538) where the text no doubt was

" $\mathrm{i}$ [i. e. one] deuil a woman to speak may constrain, But all that in hel be cannot let it again,"

Mr. Hazlitt changes " $\mathrm{i}$ " to " $\mathrm{A}$," and says in a note, "Old ed. has I." That by his correction he should miss the point was only natural ; for he evidently conceives that the sense of a passage does not in the least concern an editor. An instance or two will suffice. In the "Knyght and his Wyfe" (Vol. II. p. 17) we read,

"The fynd tyl hure hade myche tene As hit was a sterfull we seme!"

Mr. Hazlitt in a note explains tene to mean "trouble or sorrow"; but if that were its meaning here, we should read made, and not hade, which would give to the word its other sense of altention. The last verse of the couplet Mr. Hazlitt seems to think perfectly intelligible as it stands. We should not be surprised to learn that he looked upon it as the one gem that gave lustre to a poem otherwise of the dreariest. We fear we shall rob it of all its charm for him by putting it into modern English :-

"As it was after full well seen."

So in the "Smyth and his Dame" (Vol. III. p. 204) we read,

\section{"It were a lytele maystry \\ To make a blynde man to se,"}

instead of "as lytell." It might, incleed, be as easy to perform the miracle on a blind man as on Mr. Hazlitt. Again, in the same poem, a little further on, 
"For I tell the now trevely,

Is none so wyse ne to sle,

But ever ye may som what lere,"

which, of course, should be,

$$
\text { "ne so sle }
$$

But ever he may som what lere."

Worse than all, Mr. Hazlitt tells us (Vol. I. p. 158) that when they bury the great Khan, they lay his body in a tabernacle,

"With sheld and spere and other wede

With a whit mere to gyf him in ylke."

We will let Sir John Maundeville correct the last verse : "And they seyn that when he shale come into another World . . . the mare schalle gheven him myll:" Mr. Hazlitt gives us some wretched doggerel by "Piers of Fulham," and gives it swarming with blunders. We take at random a couple of specimens :-

"And loveship goith ay to warke

Where that presence is put a bake," (Vol. II. pp. 13, 14,)

where we should read "love's ship," "wrake," and "abake." Again, just below,

"Ffor men haue seyn here to foryn,

That love laughet when men be forsworn."

Love should be "Iove." Ovid is the obscure person alluded to in the "men here to foryn" :

"Jupiter e cœlo perjuria ridet amantum."

We dare say Mr. Hazlitt, if he ever read the passage, took it for granted that "to foryn" meant ton foreign, and gave it up in despair. But surely Shakespeare's

\section{They say, Jove laughs,"}

"At lovers" perjuries,

is not too foreign to have put him on the right scent.

Mr. Hazlitt is so particular in giving us $v$ for $u$ and vice versa, that such oversights are a little annoying. 
Every man his own editor scems to be his theory of the way in which old poetry should be reprinted. On this plan, the more riddles you leave (or make) for the reader to solve, the more pleasure you give him. To correct the blunders in any book edited by Mr. Hazlitt would give the young student a pretty thorough training in archaic English. In this sense the volumes before us might be safely recommended to colleges and schools. When Mr. Hazlitt undertakes to correct, he is pretty sure to go wrong. For cxample, in "Doctour Doubble Ale" (Vol. III. p. 309) he amends thus :-

"And sometyme mikle strife is Among the ale wyfes, [y-wis];

where the original is right as it stands. Just before, in the same poem, we have a parallel instance :-

"And doctours dulpatis

That falsely to them pratis, And bring them to the gates."

The original probably reads (or should read) wyfis and gatis. But it is too much to expect of Mr. Hazlitt that he should remember the very poems he is editing from one page to another, nay, as we shall presently show, that he should even read them. He will change be into ben where he should have let it alone (though his own volumes might have furnished him with such examples as "wore go," "have se," "is do," and fifty more), but he will sternly retain bene where the rhyme requires be, and Ritson had so printed. In "Adam Bel" the word pryme occurs (Vol. II. p. 140), and he rouchsafes us the following note: "i. e. noon. It is commonly used by early writers in this sense. Tn the Four P. P., by John Heywood, cirea 1540 , the apothecary says

'If he taste this boxe nye aboute the pryme By the masse, he is in heven or even songe tyme." 
Let our readers admire with us the easy "it is commonly used" of Mr. Hazlitt, as if he had store of other examples in his note-book. He could an if he would! But unhappily he borrowed this single quotation from Nares, and, as usual, it throws no scintilla of light upon the point in question, for his habit in annotation is to find by means of a glossary some passage (or passages if possible) in which the word to be explained occurs, and then - why, then to give the word as an explanation of itself. But in this instance, Mr. Hazlitt, by the time he had reached the middle of his next volume (Vol. III. p. 281) had wholly forgotten that pryme was "commonly used by early writers " for noon, and in a note on the following passage,

"I know not whates a clocke

But by the countre cocke,

The mone nor yet the pryme,

Vntyll the sonne do shyne,"

he informs us that it means "six o"clock in the morning" ! Here again this editor, who taxes Ritson with want of care, prints mone for none in the very verse he is annotating, and which we may therefore presume that he had read. A man who did not know the moon till the sun showed it him is a match even for Mr. Hazlitt himself. We wish it were as easy as he seems to think it to settle cxactly what pryme means when used by our "early writers," but it is at least absolutely certain that it did not mean noon.

But Mr. Hazlitt, if these volumes are competent witnesses, knows nothing whatever about English, old or new. In the "Nery Jest of Dane Hew" he finds the following verses,

"Dame he srid what shall we now doo

Sir she said so mote go

The munk in a corner ye shall lay" 
which we print purposely without punctuation. Mr. Hazlitt prints them thus,

"Dame, he said, what shall we now doo?

Sir, she said, so mote [it] go.

The munk," \&c.,

and gives us a note on the locution he has invented to this effect, "? so might it be managed." And the Chancellor said, I doubt! Mr. Hazlitt's query makes such a singular exception to his more natural mood of immediate inspiration that it is almost pathetic. The amended verse, as everybody (not confused by too great familiarity with our "carly writers") knows, should read,

\section{"Sir, she said, so might I go,"}

and should be followed only by a comma, to show its connection with the next. The phrase "so mote I go," is as common as a weed in the works of the elder pocts, both French and English; it occurs several times in Mr. Hazlitt's own collection, and its other form, "so mote I fire," which may also be found there, explains its meaning. On the phrase point-device (Vol. III. p. 117) Mr. Hizlitt has a positively incredible note, of which we copy only a part: "This torm, which is commonly used in early pocms" [mark once more his intimacy with our carlier literature] " to signify extreme exactitude, originated in the points which were marked on the astrolabe, as one of the means which the astrologers and dabblers in the black art adopted to enable them (as they pretended) to read the fortunes of those by whom they were consulted in the stars and planctary orbs. The excessive precision which was held to he requisite in the delineation of these points" [the delineation of a point is good!] "dre. on the astrolabe, led to point-device, or points-device (as it is sometimes found spelled), boing used as a proverbial expression for minute accuracy of 
any kind." Then follows a quotation from Gower, in which an astrolabe is spoken of "with points and cercles merveilous," and the note proceeds thus: "Shakespeare makes use of a similar figure of speech in the Tempest, I. 2, where the following dialogue takes place between Prospero and Ariel :-

'Prosp. Hast thou, spirit, Performed to point the tempest that I bade thee?

Ar. In every article.' "

Neither the proposed etymology nor the illustration requires any remark from us. We will only say that point-device is excellently explained and illustrated by Wedgrood.

We will give a few more examples out of many to show Mr. Hazlitt's utter unfitness for the task he has undertaken. In the "Kyng and the Hermyt" are the following verses,

"A wyld wey, I hold, it were

The wey to wend, I you swere,

Bot ye the dey may se,"

meaning simply, "I think it would be a wild thing (in you) to go on your way unless you wait for daylight." Mr. Hazlitt punctuates and amends thus :-

"A wyld wey I hold it were,

The wey to wend, I you swere,

Ye bot [by] the dey may se." (Vol. I. p. 19.)

The word bot seems a stumbling-block to Mr. Hazlitt. On page 54 of the same volume we have,

"Herd i neuere bi no leuedi

Hote hendinesse and curteysi."

The use of the word by as in this passage would seem familiar enough, and ret in the "Hye Way to the Spittel Hous" Mr. Hazlitt explains it as meaning be. Any boy knows that without sometimes means unless (Fielding uses it often in that sense), but Mr. Hazlitt 
seems unaware of the fact. In his first volume (p. 224) he gravely prints :-

"They trowed verelye that she shoulde dye; With that our ladye wold her helpe and spede."

The semicolon after dye shows that this is not a misprint, but that the editor saw no connection between the first verse and the second. In the same volume (p. 133) we have the verse,

"He was a grete tenement man, and ryche of londe and lede," and to lede Mr. Hazlitt appends this note: "Lede, in early English, is found in various significations, but here stands as the plural of lad, a servant." In what conceivable sense is it the plural of lad? And does lad necessarily mean a scrrant? The Promptorium has ladde glossed by garcio, but the meaning servant, as in the parallel cases of ras, puer, garçon, and boy, was a derivative one, and of later origin. The word means simply man (in the generic sense) and in the plural people. So in the "Squyr of Low Degre,"

"I will forsake both land and lede,"

and in the "Smyth and his Dame,"

"That hath both land and lyth."

The word was not "used in rarious significations." Even so lately as "Flodden Ffeild" we find,

"He was a noble leed of high degree."

Connected with land it was a commonplace in German as well as in English. So in the Tristan of Godfrey of Strasburg,

\section{"Er 2evald) fin livt bute fit lant "2u fines marfcalteg bant."}

Mr. Hazlitt is more nearly right than usual when he says that in the particular case cited above lece means servants. But were these of only one sex? Does he not know that even in the middle of the last century when 
an English nobleman spoke of "my people," he meant simply his domestics?

Encountering the familiar phrase No do! (Vol. IV. p. 64), Mr. Hazlitt changes it to Not do! He informs us that Goddes are (Vol. I. p. 197) means "God's heir"? He says (Vol II. p. 146): "To borrow, in the sense of to take, to guard, or to protect, is so common in early English that it is umnecessary to bring forward any illustration of its use in this way." But he relents, and presently gives us two from Ralph Roister Doister, each containing the phrase "Saint George to borrow!" That borrow means take no owner of books need be told, and Mr. Hazlitt has shown great skill in borrowing other people's illustrations for his notes, but the phrase he quotes has no such meaning as he gives it. Mr. Dyce in a note on Skelton explains it rightly, "St. George being my pledge or surety."

We gather a few more of these flowers of exposition and etymology :-

"The while thou sittest in chirche, thi bedys schalt thou bidde."

(Vol. I. p. 181.)

i. e. thou shalt offer thy prayers. Mr. Hazlitt's note on bidde is, "i. e. bead. So in The Kyng and the Hermit, line 111:

'That herd an hermyte there within

Unto the gate he gan to wyn

Bedying his prayer.'"

Precisely what Mr. Hazlitt understands by beading (or indeed by anything else) we shall not presume to divine, but we should like to hear him translate "if any man bidde the worshyp," which comes a few lines further on. Now let us turn to page 191 of the same volume. "Maydenys ben loneliche and no thing sekir." Mr. Hazlitt tells us in a note that "sekir or sicker" is a very common form of secure, and quotes in illustration 
from the prose Morte Artluce, "A ! said Sir Launcelut, comfort yourselfe, for it shall bee unto us as a great honour, and much more then if we died in any other places: for of death wee be sicker." Now in the text the word means safe, and in the note it means sure. Indeed sure, which is only a shorter form of secure, is its ordinary meaning. "I mak sicker," said Kirkpatrick, a not unfitting motto for certain editors, if they explained it in their usual phonetic way.

In the "Frere and the Boye," when the old man has given the boy a bow, he says :-

\section{"Shote therin, whan thou good thynke; \\ For $y f$ thou shote and wynke, The prycke thow shalte hytte."}

Mr. Hazlitt's explanation of wynke is "to close one eye in taking aim," and he quotes a passage from Gascoigne in support of it. Whatever Gascoigne meant by the word (which is very doubtful), it means nothing of the kind here, and is another proof that Mr. Hazlitt does not think it so important to understand what he reads as St. Philip did. What the old man said was, "even if you shut both your eyes, you can't help hitting the mark." So in "Piers Ploughman" (Whitaker's text),

"Wynkyng, as it were, wytterly ich saw hyt."

Again, for our editor's blunders are as endless as the heads of an old-fashioned sermon, in the "Schole-House of Women" (Vol. IV. p. 130), Mr. Hazlitt has a note on the phrase "make it nice,"

\section{("And yet alwaies they bible bable Of euery matter and make it nice,")}

which reads thus: "To make it pleasant or snug. I do not remember to have seen the word used in this senso very frequently. But Gascoigne has it in a precisely similar way :- 
'The glosse of gorgeous Courtes by thee did please mine eye,

A stately sight me thought it was to see the braue go by,

To see their feathers flatunte, to make [marke!] their straunge deuise,

To lie along in ladies lappes, to lispe, and make it nice.' "

To make it nice means nothing more nor less than to play the fool, or rather, to make a fool of yourself, faire le uicis. In old English the French niais and nice, from similarity of form and analogy of meaning, naturally fused together in the word nice, which, by an unusual luck, has been promoted from a derogatory to a respectful sense. Gascoigne's lispe might have put Mr. Hazlitt on his guard, if he ever considered the sense of what he quotes. But he never does, nor of what he edits either. For example, in the "Smyth and his Dame" we find the following note: "Prove, or proffe, is not at all uncommon as a form of profit. In the 'Seven Names of a Prison,' a poem printed in Reliquice Antiquae, we have, -

'Quintum nomen istius foveæ ita probatum,

A place of proff for man to know bothe frend and foo." "

Now proff and prov are radically different words. Proff here means proof, and if Mr. Hazlitt had read the stanza which he quotes, he would have found (as in all the others of the same poem) the meaning repeated in Latin in the last line, probacio amicorum.

But we wish to leave our readers (if not Mr. Hazlitt) in good humor, and accordingly we have reserved two of his notes as bonnes bouches. In "Adam Bel," when the outlaws ask pardon of the king,

"They kneled downe without lettyng

And each helde vp his hande."

To this passage (tolerably plain to those not too familiar with "our early literature") Mr. Hazlitt appends this solemn note: "To hold up the hand was formerly a sign of respect or concurrence, or a mode of taking an oath; 
and thirdly as a signal for mercy. In all these senses it has been employed from the most ancient times; nor is it yet out of practice, as many savage nations still testify their respect to a superior by holding their hand [either their hands or the hand, Mr. Hazlitt!] over their head. Touching the hat appears to be a vestige of the same custom. In the present passage the three outlaws may be understood to kneel on approaching the throne, and to hold up each a hand as a token that they desire to ask the royal clemency or fitrour. In the lines which are subjoined it [what?] implies a solemn assent to an oath :

'This, swore the duke and all his men, And all the lordes that with him lend, And tharto to * held they up thaire hand.' ",

Ninot's Poems, ed. 1825, p. 9.

The admirable Tupper could not have done better than this, even so far as the mere English of it is concerned. Where all is so fine, we hesitate to declare a preference, but, on the whole, must give in to the passage about touching the hat, which is as good as "mobbled queen." The Americans are still among the "savage nations" who "imply a solemn assent to an oath" by holding up the hand. Mr. Hazlitt does not seem to know that the question whether to kiss the book or hold up the hand was once a scrious one in English politics.

But Mr. Hazlitt can do better even than this! Our readers may be incredulous; but we shall proceed to show that he can. In the "Schole-House of Women," among much other equally delicate satire of the other sex (if we may venture still to call them so), the satirist undertakes to prove that woman was made, not of the rib of a man, but of a dog :-

* The to is, we need not say, an addition of Mr. Hazlitt's. What faith can we put in the text of a man who so often copies even his quotations inaccurately? 


\section{b. And yet the rib, as I suppose, That God did take out of the man A dog vp caught, and a way gose Eat it clene; so that as than The woork to finish that God began \\ Could not be, as we haue said, Because the dog the rib conuaid. \\ A remedy God found as yet; \\ Out of the dog lie took a rib."}

Mr. Hazlitt has a long note ou way gose, of which the first sentence shall suffice us: "The origin of the term way-goose is involved in some obscurity." We should think so, to be sure! Let us modernize the spelling and grammar, and correct the punctuation, and then see how it looks :-

\section{"A dog up caught and away goes, Eats it up."}

We will ask Mr. Hazlitt to compare the text, as he prints it, with

"Into the hall he gose." (Vol. III. p. 67.)

We should have expected a note here on the "hall hegoose." Not to speak of the point of the joke, such as it is, a goose that could eat up a man's rib could only be matched by one that could swallow such a note, - or write it!

We hare made but a small florilegium from Mr. Hazlitt's remarkable volumes. His editorial method seems to have been to print as the Lord would, till his eye was caught by some word he did not understand, and then to make the reader comfortable by a note showing that the editor is as much in the dark as he. We are profoundly thankful for the omission of a glossary. It would have been a nursery and seminary of blunder. To expose pretentious charlataury is sometimes the unpleasant duty of a reviewer. It is a duty we never seck, and should not have assumed in this case but for the impertinence with 
which Mr. Hazlitt has treated dead and living scholars, the latchets of whose shoes he is not worthy to unloose, and to express their gratitude to whom is, or ought to be, a pleasure to all honest lovers of their mother-tongue. If he who has most to learn be the happiest man, Mr. Hazlitt is indeed to be envied; but we hope he will learn a great deal before he lays his prentice hands on Warton's "History of English Poctry," a classic in its own way. If he does not learn before, he will be likely to learn after, and in no agreeable fashion. 


\section{EMERSON THE LECTURER.}

TT is a singular fact, that Mr. Emerson is the most 1 steadily attractive lecturer in America. Into that somewhat cold-waterish region adventurers of the sensational kind come down now and then with a splash, to become disregarded King Logs before the next season. But Mr. Emerson always draws. A lecturer now for something like a third of a century, one of the pioneers of the lecturing system, the charm of his voice, his manner, and his matter has never lost its power over his earlier hearers, and continually winds new ones in its enchanting meshes. What they do not fully understand they take on trust, and listen, saying to themselves, as the old poet of Sir Philip Sidney, -

"A sweet, attractive, kind of grace, A full assurance given by looks, Continual comfort in a face,

The lineaments of gospel books."

We call it a singular fact, because we Yankees are thought to be fond of the spread-eagle style, and nothing can be more remote from that than his. We are reckoned a practical folk, who would rather hear about a new air-tight stove than about Plato; yet our favorite teacher's practicality is not in the least of the Poor Richard variety. If he have any Buncombe constituency, it is that unrealized commonwealth of philosophers which Plotimus proposed to establish; and if he were to make an almanac, his directions to farmers would 
be something like this: "Oстовеn: Indian Summer; now is the time to get in your early Vedas." What, then, is his secret? Is it not that he out-Yankees us all? that his range includes us all? that he is equally at home with the potato-disease and original sin, with peg. ging shoes and the Over-soul? that, as we try all trades, so has he tried all cultures? and above all, that his mysticism gives us a counterpoise to our super-practicality?

There is no man living to whom, as a writer, so many of us feel and thankfully acknowledge so great an indebtedness for ennobling impulses, - none whom so many cammot abide. What does he mean? ask these last. Where is his system? What is the use of it all? What the deuse have we to do with Brahma? I do not propose to write an essay on Emerson at this time. I will only say that one may find grandeur and consolation in a starlit night without caring to ask what it means, save grandeur and consolation; one may like Montaigne, as some ten generations before us have done, without thinking him so systematic as some more eminently tedious (or shall we say tediously eminent?) authors; one may think roses as good in their way as cabbages, though the latter would make a better show in the witness-box, if cross-examined as to their usefulness; and as for Brahma, why, he can take care of himself, and won't bite us at any rate.

The boiher with Mr. Emerson is, that, though he writes in prose, he is essentially a poet. If you undertake to paraphrase what he says, and to reduce it to words of one syllable for infant minds, you will make as sad work of it as the good monk with his analysis of Homer in the "Epistolie Obscurorum Virorum." We look upon him as one of the few men of genius whom our age has prodiced, and there needs no better proof 
of it than his masculine faculty of fecundating other minds. Search for his eloquence in his books and you will perchance miss it, but meanwhile you will find that it has kindled all your thoughts. For choice and pith of language he belongs to a better age than ours, and might rub shoulders with Fuller and Browne, - though he does use that abominable word reliable. His eye for a fine, telling phrase that will carry true is like that of a backwoodsman for a rifle; and he will dredge you up a choice word from the mud of Cotton Mather himself. A diction at once so rich and so homely as his I know not where to mateh in these days of writing by the page; it is like homespun cloth-of-gold. The many cannot miss his meaning, and only the few can find it. It is the open secret of all true genius. It is wholesome to angle in those profound pools, though one be rewarded with nothing more than the leap of a fish that flashes his freckled side in the sun and as suddenly absconds in the dark and dreamy waters again. There is keen cxcitement, though there be no ponderable acquisition. If we carry nothing home in our baskets, there is ample gain in dilated lungs and stimulated blood. What does he mean, quotha? He means inspiring hints, a divining-rod to your deeper nature. No doubt, Emerson, like all original men, has his peculiar audience, and yet I know none that can hold a promiscuous crowd in pleased attention so long as he. As in all original men, there is something for every palate. "Would you know," says Goethe, "the ripest cherries? Ask the boys and the blackbirds."

The announcement that such a pleasure as a new course of lectures by him is coming, to people as old as I am, is something like those forebodings of spring that prepare us every year for a fimiliar novelty, none the less novel, when it arrives, becanse it is familiar. To 
know perfectly well what we are to expect from $\mathrm{Mr}$. Emerson, and yet what he says always penctrates and stirs us, as is apt to be the case with genius, in a very unlooked-for fashion. Perhaps genius is one of the few things which we gladly allow to repeat itself, - one of the few that multiply rather than weaken the force of their impression by iteration? Perhaps some of us hear more than the mere words, are moved by something deeper than the thoughts? If it be so, we are quite right, for it is thirty years and more of "plain living and high thinking" that speak to us in this altogether unique lay-preacher. We have shared in the beneficence of this varied culture, this fearless impartiality in criticism and speculation, this masculine sincerity, this sweetness of nature which rather stimulates than cloys, for a generation long. If ever there was a standing testimonial to the cumulative power and value of Character, (and we need it sadly in these days,) we have it in this gracious and dignified presence. What an antiseptic is a pure life! At sixty-five (or two years beyond his grand climacteric, as he would prefer to call it) he has that privilege of soul which abolishes the calcndar, and presents him to us always the unwasted contemporary of his own prime. I do not know if he seem old to his younger hearers, but we who have known him so long wonder at the tenacity with which he maintains himself even in the outposts of youth. I suppose it is not the Emerson of 1868 to whom we listen. For us the whole life of the man is distilled in the clear drop of every sentence, and behind each word we divine the force of a noble character, the weight of a large capital of thinking and being. We do not go to hear what Emerson says so much as to hear Emerson. Not that we perceive any falling-off in anything that ever was essential to the charm of Mr. Emerson's peculiar style of thonghlst 
or phrase. The first lecture, to be sure, was more disjointed even than common. It was as if, after vainly trying to get his paragraphs into sequence and order, he had at last tried the desperate expedient of shuffiling them. It was chaos come again, but it was a chaos full of shooting-stars, a jumble of creative forces. The second lecture, on "Criticism and Poetry," was quite up to the level of old times, full of that power of strangely. subtle association whose indirect approaches startle the mind into almost painful attention, of those flashes of mutual understanding between speaker and hearer that are gone ere one can say it lightens. The vice of $\mathrm{Em}$. erson's criticism seems to be, that while no man is so sensitive to what is poetical, few men are less sensible than he of what makes a poem. He values the solid meaning of thought above the subtler meaning of style. He would prefer Donne, I suspect, to Spenser, and sometimes mistakes the queer for the original.

To be young is surely the best, if the most precarious, gift of life; yet there are some of us who would hardly consent to be young again, if it were at the cost of our recollection of Mr. Emerson's first lectures during the consulate of Van Buren. We used to walk in from the country to the Masonic Temple (I think it was), through the crisp winter night, and listen to that thrilling voice of his, so charged with subtle meaning and subtle music, as shipwrecked men on a raft to the hail of a ship that came with unhoped-for food and rescue. Cynics might say what they liked. Did our own imaginations transfigure dry remainder-biscuit into ambrosia? At any rate, he brought us life, which, on the whole, is no bad thing. Was it all transcendentalism? magic-lantern pictures on mist? As you will. Those, then, were just what we wanted. But it was not so. The delight and the benefit were that he put us in communication with 
a larger style of thought, sharpened our wits with a more pumgent phrase, gave us ravishing glimpses of an ideal under the dry husk of our New England; made us conscious of the supreme and everlasting originality of whatever bit of soul might be in any of us; freed us, in short, from the stocks of prose in which we had sat so long that we had grown wellnigh contented in our cramps. And who that saw the audience will erer forget it, where every one still capable of fire, or longing to renew in them the half-forgotten sense of it, was githered? Those faces, young and old, agleam with pale intellectual light, eager with pleased attention, flash upon me once more from the decp recesses of the years with an exquisite pathos. Ah, beautiful young eyes, brimming with love and hope, wholly ranished now in that other world we call the Past, or peering doubtfully through the pensive gloaming of memory, your light impoverishes these cheaper days! I hear again that rustle of sensation, as they turned to exchange glances over some pithier thought, some keener flash of that humor which always played about the horizon of his mind like heat-lightning, and it seems now like the sad whisper of the autumn leares that are whirling around me. But would my picture be complete if I forgot that ample and regete countenance of $\mathrm{Mr} . \mathrm{R}-$ of $\mathrm{IV}-$, - how, from its regular post at the corner of the front bench, it turned in ruddy triumph to the profaner audience as if he were the inexplicably appointed fugleman of appreciation? I was reminded of him by those hearty cherulos in Titian's Assumption that look at you as who should say, "Did you ever see a Middomna like that? Dil you ever behold one hundred and fifty pounds of womanhood mount heavenward before like a rocket?"

To some of us that long-past experience remains as the most marvellous and fruitful we have ever had. Emerson 
nwakened us, saved us from the body of this death. It is the sound of the trumpet that the young soul longs for, careless what breath may fill it. Sidney heard it in the ballad of "Chevy Chase," and we in Emerson. Nor did it blow retreat, but called to us with assurance of victory. Did they say he was disconnected? So were the stars, that seemed larger to our eyes, still keen with that excitement, as we walked homeward with prouder stride over the creaking snow. And were they not knit together by a higher logic than our mere sense could master? Were we enthusiasts? I hope and believe we were, and am thankful to the man who made us worth something for once in our lives. If asked what was left? what we carried home? we should not have been careful for an answer. It would have been enough if we had said that something beautiful had passed that way. Or we might have asked in return what one brought away from a symphony of Beethoven? Enough that he had set that ferment of wholesome discontent at work in us. There is onc, at least, of those old hearers, so many of whom are now in the fruition of that intellectual beauty of which Emerson gave them both the desire and the foretaste, who will always love to repent :-

\section{"Che in la mente m'è fitta, ed or m'accuora}

La cara e buona immagine paterna

Di voi, quando nel mondo ad ora ad ora

I'insegnavaste come l'uom s'eterna."

I am unconscionsly thinking, as I write, of the third lecture of the present course, in which Mr. Emerson gave some delightful reminiscences of the intellectual influences in whose movement he had shared. It was like hearing Goethe read some passages of the "Wahrheit aus seinem Leben." Not that there was not a little Dichtung, too, here and there, as the lecturer built up so lofty a pedestal under certain figures as to lift them 
into a prominence of obscurity, and seem to masthead them there. Everybody was asking his neighbor who this or that recondite great man was, in the faint hope that somebody might once have heard of him. There are those who call Mr. Emerson cold. Let them revise their judgment in presence of this loyalty of his that can keep warm for half a century, that never forgets a friendship, or fails to pay eren a fancied obligation to the uttermost farthing. This substantiation of shadows was but incidental, and pleasantly characteristic of the man to those who know and love him. The greater part of the lecture was deroted to reminiscences of things sulstantial in themselves. He spoke of Everett, fresh from Greece and Germany ; of Chamning ; of the translations of Margaret Fuller, Ripley, and Dwight; of the Dial and Brook Farm. To what he said of the latter an undertone of good-humored irony gave special zest. But what every one of his hearers felt was that the protagonist in the drama was left out. The lecturer was no. Eneas to babble the quorum magna pars fui, and, as one of his listeners, I cannot help wishing to say how each of them was commenting the story as it went along, and filling up the necessary gaps in it from his orm private store of memories. His younger hearers could not know how much they owed to the benign impersonality, the quiet scorn of everything ignoble, the never-sated hunger of self-culture, that were personified in the man before them. But the older knew how much the country's intellectual emancipation was due to the stimulus of his teaching and example, how constantly he had kept burning the beacon of an ideal life alove our lower region of turmoil. To him more than to all other causes together did the young martyrs of our civil war owe the sustaining strength of thoughtful heroism that is so touching in every record of their lives. Those who are 
grateful to Mr. Emerson, as many of us are, for what they feel to be most valuable in their culture, or perhaps I should say their impulse, are grateful not so much for any direct teachings of his as for that inspiring lift which only genius can give, and without which all doctrine is chaff.

This was something like the caret which some of us older boys wished to fill up on the margin of the master's lecture. Few men have been so much to so many, and through so large a range of aptitudes and temperaments, and this simply because all of us value manhood beyond any or all other qualities of charncter. We may suspect in him, here and there, a certain thinness and vagueness of quality, but let the waters go over him as they list, this masculine fibre of his will keep its lively color and its toughness of texture. I have heard some great speakers and some accomplished orators, but never any that so moved and persuaded men as he. There is a kind of undertow in that rich baritone of his that sweeps our minds from their foothold into deeper waters with a drift we cannot and would not resist. And how artfully (for Emerson is a long-studied artist in these things) does the deliberate utterance, that seems waiting for the fit word, appear to admit us partners in the labor of thought and make us feel as if the glance of humor were a sudden suggestion, as if the perfect phrase lying written there on the desk were as unexpected to him as to us! In that closely-filed speech of his at the Burns centenary dinner every word seemed to have just dropped lown to him from the clouds. He looked far away over the heads of his hearers, with a vagne kind of expectation, as into some private heaven of invention, and the winged period came at last obedient to his spell. "My dainty Ariel!" he seemed murmuring to himself as he cast down his eyes as if in deprecation of the frenzy of 
approval and caught another sentence from the Sibylline leaves that lay before him ambushed bohind a dish of fruit and seen only by nearest neighbors. Every sentenco brought down the house, as I never saw one brought down before, - and it is not so easy to hit Scotsmen with a sentiment that has no hint of native brogue in it. I watched, for it was an interesting study, how the quick sympathy ran flashing from face to face down the long tables, like an electric spark thrilling as it went, and then exploded in a thunder of plaudits. I watched till tables and faces vanished, for I, too, found myself caught up in the common enthusiasm, and my excited fancy set me under the bema listening to him who fulmined over Greece. I can never help applying to him what Ben Jonson said of Bacon: "There happened in my time one noble speaker, who was full of gravity in his speaking. His language was nobly censorious. No man ever spake more neatly, more pressly, more weightily, or suffered less emptiness, less idleness, in what he uttered. No member of his speech but consisted of his own graces. His hearcrs could not cough, or look aside from him, without loss. He commanded where he spoke." Those who heard him while their natures were yet plastic, and their mental nerves trembled under the slightest breath of divine air, will nerer cease to feel and say :-

"Was never eye did see that face,

Was never ear did hear that tongue, Was never mind did mind his grace,

That ever thought the travail long; But eyes; and ears, and every thought, Were with his sweet perfections caught." 


\section{POPE.}

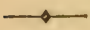

TN 1675 Edward Phillips, the elder of Milton's I nephews, published his Theatrum Poetarum. In his Preface and elsewhere there can be little doubt that he reflected the rsthetic principles and literary judgments of his now illustrious uncle, who had died in obscurity the year before.* The great poet who gare to English blank verse the grandeur and compass of organ-music, and who in his minor poems kept alive the traditions of Fletcher and Shakespeare, died with no foretaste, and yet we may believe as confident as ever, of that " immortality of fame" which he tells his friend Diodati he was "meditating with the help of Heaven" in his youth. He who may have scen Shakespeare, who doubtless had seen Fletcher, and who perhaps personally knew Jonson, $\uparrow$ lived to see that false school of writers whom he qualified as "good rhymists, but no poets," at once the idols and the victims of the taste they had corrupted. As he saw, not without scorn, how they found universal hearing, while he slowly won his audience fit though few, did he ever think of the hero of his own epic at the ear of Eve? It is not impossible; but however that may be, he sowed in his nephew's book the dragon's teeth of that long war which, after the lapse of a century and a

* This was Thomas Warton's opinion.

† Milton, a London boy, was in his eighth, serenteenth, and twentyninth years, respectively, when Shakespeare (1616), Fletcher (1625), and B. Jonson (1637) died. 
half, was to end in the expulsion of the usurping dynasty and the restoration of the ancient and legitimate race whose claim rested on the grace of God. In the following passage surely the voice is Milton's, though the hand be that of Phillips: "Wit, ingenuity, and learning in verse, cren elegancy itself, though that comes nearest, are one thing; true native poetry is another, in which there is a certain air and spirit, which, perhaps, the most learned and judicious in other arts do not perfectly apprehend; much less is it attainable by any art or study." The man who speaks of elegancy as coming nearest, certainly shared, if he was not repeating, the opinions of him who thirty years before had said that "decorum" (meaning a higher or organic unity) was "the grand masterpiece to observe" in poetry.*

It is upon this text of Phillips (as Chalmers has remarked) that Joseph Warton bases his classification of poets in the dedication to Young of the first rolume of his essay on the Genius and Writings of Pope, published in 1756 . That was the earliest public and official declaration of war against the reigning mode, though private hostilities and reprisals had been going on for some time. Addison's panegyric of Milton in the Spectator was a criticism, not the less damaging becanse indirect, of the superficial poetry then in roguc. His praise of the old ballads condemned by innuendo the artificial elaboration of the drawing-room pastoral by contrasting it with the simple sincerity of nature. Himself incapable of being natural except in prose, he had an instinct for the genuine virtues of poetry as sure as that of Gray. Thomson's "Winter" (1726) was a direct protest against the literature of Good Society, going as it did to prove that the noblest society was that of one's own mind heightened by the contemplation of outward

* In his Tractate on Education. 
nature. What Thomson's poetical creed was may be surely inferred from his having modelled his two principal poems on Milton and Spenser, imnoring rhyme altogether in the "Seasuns," and in the "Castle of Indolence" rejecting the stiff mould of the couplet. In $17+4$ came Akenside's "Pleasures of Imagination," whose very title, like a guide-post, points away from the level highway of commonplace to momntain-paths and less domestic prospects. The poem was stiff and unwilling, but in its loins lay the seed of nobler births, and without it the "Lines written at Tintern Abbey" might never have been. Three years later Collins printed his little volume of Odes, advocating in theory and exemplifying in practice the natural supremacy of the magination (though he called it by its older name of fancy) as a test to distinguish poetry from verse-making. The whole Romantic School, in its germ, no doubt, but yet unmistakably foreshadowed, lies already in the "Ode on the Superstitions of the Highlands." $\mathrm{He}$ was the first to bring back into poetry something of the antique ferror, and found again the long-lost secret of being classically elegant without being pedantically cold. A skilled lover of music,* he rose from the general sing-song of his generation to a harmony that had been silent since Milton, and in him, to use his own words,

"The force of energy is found,

And the sense rises on the wings of sound."

But beside his own direet services in the reformation of our poetry, we owe him a still greater delut as the inspirer of Gray, whose "Progress of Poesy," in reach, variety, and loftiness of poise, overflies all other English lyries like an eagle. In spite of the dulness of contemporary cars, preoccupied with the continuous hum

Milton, Collins, and Gray, our three great masters of harmony: were all musicians. 
of the popular hurdy-gurdy, it was the prevailing blast of Gray's trumpet that more than anything else called men back to the legitimate standard.* Another poet, Dyer, whose "Fleece" was published in 1753 , both in the choice of his subject and his treatment of it gives further proof of the tendency among the younger generation to revert to simpler and purer models. Plainly

* Wordsworth, who recognized forerumers in Thomson, Collins, Dyer, and Burns, and who chimes in with the popular superstition about Chatterton, is always somewhat niggardly in his appreciation of Gray. Yet he owed him not a little. Without Gray's tune in his ears, his own noblest Ode would have missed the varied modulation which is one of its main charms. Where he forgets Gray, his verse sinks to something like the measure of a jig. Perhaps the suggestion of one of his own finest lines,

\section{("The light that never was on land or sea,")}

was due to Gray's

\section{"Orient hues unborrowed of the sun."}

I believe it has not been noticed that among the verses in Gray's "Somnet on the Death of West," which Wordsworth condemns as of no value, the second -

\section{"And reddening Phœbus lifts his golden fires"-}

is one of Gray's liappy reminiscences from a poet in some respects greater than either of them:-

\section{Jamque rubrum tremulis jubar ignibus erigere alle Cum cœptat natura.}

\section{Lecret, iv. 404, 405.}

Gray's taste was a sensitive divining-rod of the sources whether of pleasing or profound emotion in poetry. Though he prized pomp, he did not unlervalue simplicity of subject or treatment, if only the witch Imagination had cast her spell there. Wordsworth loved solitude in his appreciations as well as in his daily life, and was the readier to find merit in obscurity, because it gave him the pleasure of being a first diseoverer all by himself. Thus he addresses a sonnet to John Dyer. But Gray was one of "the pure and powerful minds" who had discovered Iyer during his lifetime, when the discovery of poets is more difficult. In 1753 he writes to Walpole: "NIr. Dyer has more poetry in his imagination than almost any of our number, but rough and injudicions." Dyer has one fine verse, -

$$
\text { "On the dark level of adversity." }
$$


enough, Thomson had been his chief model, though there are also traces of a careful study of Milton.

Pope had died in 1744, at the height of his renown, the acknowledged monarch of letters, as supreme as Voltaire when the excitement and exposure of his coronation-ceremonies at Paris hastened his end a generation later. His fame, like Voltaire's, was European, and the style which he had carried to perfection was paramount throughout the cultivated world. The new edition of the "Dunciad," with the Fourth Book added, published the year before his death, though the substitution of Cibber for Theobald made the poem incoherent, had yet increased his reputation and confirmed the sway of the school whose recognized head he was, by the poignancy of its satire, the lucidity of its wit, and the resounding, if somewhat uniform march, of its numbers. He had been translated into other languages living and dead. Voltaire had long before pronounced him "the best poet of England, and at present of all the world." * It was the apotheosis of clearness, point, and technical skill, of the ease that comes of practice, not of the fulness of original power. And yet, as we have seen, while he was in the very plenitude of his power, there was already a widespread discontent, a feeling that what "comes nearest," as Phillips calls it, may yet be infinitely far from giving those profounder and incalculable satisfactions of which the soul is capable in poetry. A morement was gathering strength which prompted

"The age to quit their clogs

By the known rules of virtuous liberty."

Nor was it wholly confined to England. Symptoms of a similar reaction began to show themselves on the Conti-

* MS. letter of Voltaire, cited by Wirburton in his edition of Pope, Vol. IV. p. 5s, note. The date is 15 th October; 1726. I do not find it in Voltaire's Correspondence. 
nent, notably in the translation of Milton (1732) and the publication of the Nibelungen Lied (1757) by Bodmer, and the imitations of Thomson in France. Was it possible, then, that there was anything better than good sense, clegant diction, and the highest polish of style? Could there be an intellectual appetite which antithesis fitiled to satisfy? If the horse would only have faith enough in his green spectacles, surely the straw would acquire, not only the flaror, but the nutritious properties of fresh grass. The horse was foolish enough to starve, but the public is wiscr. It is surprising how patiently it will go on, for generation after generation, transmuting dry stubble into rerdure in this fashion.

The school which Boileau founded was critical and not creative. It was limited, not only in its essence, but by the capabilities of the French language and by the natural bent of the French mind, which finds a predominant aatisfaction in plurases if clegantly turned, and can make a clespotism, political or asthetic, palatable with the pepper of epigram. The style of Louis XIV. did what his armies failed to do. It orerran and subjugated Europe. It struck the literature of imagination with palsy, and it is droll enough to see Voltaire, after he had got some knowledge of Shakespeare, continually endeavoring to reassure himself about the poetry of the grand siècle, and all the time asking himself, "Why, in the name of all the gods at once, is this not the real thing?" He seems to have felt that there was a dreadful mistake somewhere, when poetry must be called upon to prove itself inspired, above all when it must demonstrate that it is interesting, all appearances to the contrary notwithstanding. Difficulty, according to Voltaire, is the tenth Muse; but how if there were difficulty in reading as well as writing? It was something, at any rate, which an increasing number of persons were perverse enough to feel in attempting 
the productions of a pseudo-classicism, the classicism of red heels and periwigs. Even poor old Dennis himself had arrived at a kind of muddled notion that artifice was not precisely art, that there were depths in human nature which the most perfectly manufuctured line of five feet could not sound, and passionate elations that could not be tuned to the lullaby seesaw of the couplet. The satisfactions of a conventional taste were very well in their own way, but werd they, after all, the highest of which men were capable who had obscurely divined the Greeks, and who had seen Hamlet, Lear, and Othello upon the stage? Was not poetry, then, something which delivered us from the dungeon of actual life, instead of basely reconciling us with it?

A century earlier the school of the cultists had established a dominion, ephemeral, as it soon appeared, but absolute while it lasted. Du Bartas, who may, perhaps, as fairly as any, lay claim to its paternity, had been called divine, and similar honors had been paid in turn to Gongora, Lilly, and Marini, who were in the strictest sense contemporaneous. The infection of mere fashion will hardly account satisfactorily for a vogue so sudden and so widely extended. It may well be suspected that there was some latent cause, something at work more potent than the fascinating mannerism of any single author in the rapid and almost simultaneous diffusion of this purely cutaneous eruption. It is not improbable that, in the revival of letters, men whose native tongues had not yet attained the precision and grace only to be acquired by long literary usage, should have learned from a study of the Latin poets to value the form above

* Its taste for verbal affectations is to be found in the Roman de la Rose, and (yet more absurdly foreed) in Gauthier de Coinsy; but in $\mathrm{Du}$ Bartas the research of effect not selilom subjugates the thought as well as the phrase. 
the substance, and to seek in mere words a conjuring property which belongs to them only when they catch life and meaning from profound thought or powerful emotion. Yet this very derotion to expression at the expense of everything else, though its excesses were fatal to the innovators who preached and practised it, may not have been without good results in refining language and fitting it for the higher uses to which it was destined. The cultists went down before the implacable good sense of French criticism, but the defect of this criticism was that it ignored imagination altogether, and scnt Nature albout her business as an impertinent baggage whose household loom competed unlawfully with the machine-made fabrics, so exquisitely uniform in pattern, of the royal manufactories. There is more than a fanciful analogy between the style which Pope brought into rogue and that which for a time beritched all ears in the latter half of the sixteenth century. As the master had nade it an axiom to avoid what was mean or low, so the disciples endeavored to escape from what was common. This they contrived by the ready expedient of the periphrasis. They called everything something else. A boot with them was

"The shining leather that encased the limb";

coffee became

"The fingrant juice of Mocha's berry brown";

and they were as liberal of epithets as a royal christening of proper names. Two in every verse, one to balance the other, was the smallest allowance. Here are four successive rerses from "The Vanity of Human Wishes" :

" The encumbered oar scarce leaves the dreaded coast

Through purple billows and a flonting hòst.

The bold Bavarian in a luckless hour

Tries the dread summits of Cesarian power." 
This fashion perished also by its own excess, but the criticism which laid at the door of the master all the fauits of his pupils was unjust. It was defective, moreover, in overlooking how much of what we call natural is an artificial product, above all in forgetting that Pope had one of the prime qualities of a great poet in exactly answering the intellectual needs of the age in which he lived, and in reflecting its lineaments. He did in some not inadequate sense hold the mirror up to nature. His poetry is not a mountain-tarn, like that of Worcisworth; it is not in sympathy with the higher moods of the mind; yet it continues entertaining, in spite of all changes of mode. It was a mirror in a drawing-room, hut it gave back a faithful image of society, powdered and rouged, to be sure, and intent on trifles, yet still as human in its own way as the heroes of Homer in theirs.

For the popularity of Pope, as for that of Marini and his sect, circumstances had prepared the way. English litcrature for half a century after the Restoration showed the marks both of a moral reaction and of an artistic vassalage to France. From the compulsory saintship and cropped hair of the Puritans men rushed or sneaked, as their temperaments dictated, to the opposite cant ${ }^{*}$ of sensuality and a wilderness of periwig. Charles II. had brought back with him from exile French manners, French morals, and above all French taste. Misfortune makes a shallow mind sceptical. It had made the king so; and this, at a time when court patronage was the main sinew of authorship, was fatal to the higher qualities of literature. That Charles should have preferred the stately decorums of the French school, and should have mistaken its polished mannerism for style, was natural enough. But there was something also in the texture of the average British mind which prepared it for this subjugation from the other side of the Channel. 
No observer of men can have failed to notice the clunisy respect which the understanding pays to elegance of manner aud savoir-faire, nor what an awkward sense of inferiority it feels in the presence of an accomplished worldliness. The code of society is stronger with most persons than that of Sinai, and many a man who would not scruple to thrust his fingers in his neighbor's pocket would forego green peas rather than use his knife as a shovel. The submission with which the greater number surrender their natural likings for the acquired taste of what for the moment is called the World is a highly curious phenomenon, and, however destructive of originality, is the main safeguard of society and nurse of civility. Any one who has witnessed the torments of an honest citizen in a foreign gallery before some hideous martyrdom which he feels it his duty to admire, though it be hateful to him as nightmare, may well doubt whether the gridiron of the saint were hotter than that of the sinner. It is only a great mind or a strong character that knows how to respect its own provincialism and can dare to be in fashion with itself. The bewildered clown with his "Am I Giles? or am I not?" was but a type of the average man who finds himself uniformed, drilled, and keeping step, whether he will or no, with the company into which destiny or chance has drafted him, and which is marching him inexorably away from everything that made him comfortable.

The insularity of England, while it fostered pride and reserve, entailed also that sensitiveness to ridicule which haunts pride like an evil genius. "The English," says Barclay, writing half a century before the Restoration, "have for the most part grave minds and withdrawn, as it were, into themselves for counsel; they wonderfully admire themselves and the manners, genius, and spirit of their own nation. In salutation or in 
writing they endure not (unless haply imbued with forcign mamners) to descend to those words of imaginary servitude which the refinement (blandities) of ages hath invented." * Yet their fondness of foreign fashions had long been the butt of native satirists. Every one remembers Portia's merry picture of the English lord: "How oddly he is suited! I think he bought his doublet in Italy, his round hose in France, his bounet in Germany, and his behavior everywhere." But while she laughs at his bungling efforts to make himself a cosmopolite in externals, she hints at the persistency of his inward Anglicism : "He hath neither Latin, French, nor Italian." In matters of taste the Anglo-Saxon mind seems always to have felt a painful distrust of itself, which it betrays either in an affectation of burly contempt or in a pretence of admiration equally insincere. The young lords who were to make the future court of Charles JI. no doubt found in Paris an elegance beside which the homely bluntness of native manners seemed rustic and underbred. They frequented a theatre where propriety was absolute upon the stage, though license had its full swing behind the scenes. They brought home with them to England debauched morals and that urbane discipline of manners which is so agreeable a substitute for discipline of mind. The word "genteel" came back with them, an outward symptom of the inward change. In the last generation, the men whose great aim was success in the Other World had wrought a political revolution; now, those whose ideal was prosperity in This World were to have their turn and to accomplish with their lighter wenpons as great a change. Before the end of the seventeenth century John Bull was pretty well persuaded, in a bewildered kind of way, that he had been vulgar, and especially

* Barclaii Satyricon, p. 382. Barclay had lired in France. 
that his efforts in literature showed marks of native vig. or, indeed, but of a vigor clownish and uncouth. He began to be ashamed of the provincialism which had given strength, if also something of limitation, to his character.

Waller, who spent a whole summer in polishing the life out of ten lines to be written in the Tasso of the Duchess of York, expresses the prevailing belief as regarded poetry in the prologue to his "improvement" of the "Maid's Tragedy" of Beaumont and Fletcher. He made the play reasonable, as it was called, and there is a pleasant satire in the fact that it was refused a license because there was an immoral king in it. On the throne, to be sure, - but on the stage! Forbid it, decency!

"Above our neighbors" our conceptions are, But fitultess writing is the effect of care;

Our lines reformed, and not composed in haste, Polished like marble, would like marble last.

Were we but less indulgent to our fuu'ts, And patience had to cultivate our thoughts, Our Muse would flomish, and a nobler rage Would honor this than did the Grecian stage."

It is a curious comment on these rerses in fivor of careful writing, that Waller should have failed even to express his own meaning either clearly or with propriety. He talks of "cultivating our thoughts," when he means "pruning our style"; he confounds the Muse with the laurel, or at any rate makes her a plant, and then goes on with perfect equanimity to tell us that a nobler "rage" (that is, madness) than that of Greece would follow the horticultural devices he recommends. It never seems to have occurred to Waller that it is the substance of what you polish, and not the polish itself, that insures duration. Dryden, in his rough-and-ready way, has hinted at this in his verses to Congreve on the 
"Double Dealer." He begins by stating the received theory about the improvement of English literature under the new regime, but the thin ice of sophistry over which Waller had glided smoothly gives way under his greater weight, and he finds himself in deep water ere he is aware.

"Well, then, the promised hour has come at last,

The present age in wit obscures the past:

Strong were our sires, and as they fought they writ, Conquering with force of arm * and dint of wit.

Theirs was the giant race before the Flood;

And thus when Charles returned our Empire stood;

Like Janus he the stubborn soil manured,

With rules of husbandry the rankness cured,

Tamed us to manners when the stage was rude,

And boisterous English wit with art endued;

Our age was cultivated thus at length,

But what we gained in skill we lost in strength;

Our builders were with want of genius curst,

The second temple was not like the first."

There would seem to be a manifest reminiscence of Waller's verse in the half-scornful emphasis which Dryden lays on "cultivated." Perhaps he was at first led to give greater weight to correctness and to the restraint of arbitrary rules from a consciousness that he had a tendency to hyperbole and extravagance. But he afterwards became convinced that the heightening of discourse by passion was a very different thing from the exaggeration which heaps phrase on phrase, and that genius, like beauty, can always plead its privilege. Dryden, by his powerful example, by the charm of his verse which combines rigor and fluency in a measure perhaps never reached by any other of our poets, and above all because it is never long before the sunshine of his cheerful good sense breaks through the clouds of rhetoric,

* Usually printerl arms, but Drrden certainly wrote arm, to correspond with dint, which he used in its old meaning of a downright blow. 
and gilds the clipped hedges over which his thought clambers like an unpruned vine, - Dryden, one of the most truly English of English authors, did more than all others combined to bring about the triumphs of French standards in taste and French principles in criticism. But he was always like a deserter who cannot feel happy in the victories of the alien arms, and who would go back if he could to the camp where he naturally belonged. Between 1660 and 1700 more French words, I believe, were directly transplanted into our language than in the century and a half since. What was of more consequence, French ideas came with them, shaping the form, and through that modifying the spirit, of our literature.

Voltaire, though he came later, was steeped in the theories of art which had been inherited as traditions of classicism from the preceding generation. He had lived in England, and, I have no doubt, gives us a very good notion of the tone which was prevalent there in his time, an English version of the eriticism imported from France. He tells us that Mr. Addison was the first Englishman who had written a reasonable tragedy. And in spite of the growling of poor old Dennis, whose sandy pedantry was not without an oasis of refreshing sound judgment here and there, this was the opinion of most persons at that day, except, it may be suspected, the judicions and modest Mr. Addison himself. Voltaire says of the English tragedians, - and it will be noticed that he is only putting, in another way, the opinion of Dryden, - " Their productions, almost all barbarous, without polish, order, or probability, have astonishing gleams in the midst of their night; . . . . it seems sometimes that nature is not made in England as it is elsewhere." $E$ h bien, the inference is that we must try and make it so! The world must be uniform 
in order to be comfortable, and what fashion so becoming as the one we have invented in Paris? It is not a little amusing that when Voltaire played master of ceremonies to introduce the bizarre Shakespeare among his countrymen, that other kind of nature made a profounder impression on them than quite pleased him. So he turned about presently and called his whilome protége a buffoon.

The condition of the English mind at the close of the seventeenth century was such as to make it particularly sensitive to the magnetism which streamed to it from Paris. The loyalty of everybody both in politics and religion had been put out of joint. A generation of materialists, by the natural rebound which inevitably follows over-tension, was to balance the ultra-spiritualism of the Puritans. As always when a political revolution has been wrought by moral agencies, the plunder had fallen mainly to the share of the greedy, selfish, and unscrupulous, whose disgusting cant had given a taint of hypocrisy to piety itself. Religion, from a burning conviction of the soul, had grown to be with both parties a political badge, as little typical of the inward man as the scallop of a pilgrim. Sincerity is impossible, unless it pervade the whole being, and the pretence of it saps the very foundation of character. There seems to have been an universal scepticism, and in its worst form, that is, with an outward conformity in the interest of decorum and order. There was an unbelief that did not, believe even in itself.

The difference between the leading minds of the former age and that which was supplanting it went to the very roots of the soul. Milton was willing to peril the success of his crowning work by making the poetry of it a stalking-horse for his theological convictions. What was that Fame 
"Which the clear spirit doth raise To scorn delights and live laborious days,"

to the crown of a good preacher who sets

"The hearts of men on fire

To scorn the sordid world and unto heaven aspire"?

Dean Swift, who aspired to the mitre, could write a book whose moral, if it had any, was that one religion was as good as another, since all were political devices, and accepted a cure of souls when it was more than doubtful whether he believed that his fellow-creatures had any souls to be saved, or, if they had, whether they were worth saving. The answer which Pulci's Margutte makes to Morgante, when asked if he believed in Christ or Mahomet, would have expressed well enough the creed of the majority of that generation :-

"To tell thee truly,

My faith in black's no greater than in azure, But I believe in capons, roast-ment, bouilli, And in good wine my ftith 's beyond all measure." *

It was a carnival of intellect withont firith, when men could be Protestint or Catholic, both at once, or by turns, or neither, as suited their interest, when they could swear one allegiance and licep on safe terms with the other, when prime minister's and commanders-inchief conld be intelligencers of the Pretender, nay, when even Algernon Sidncy himself could be a pensioner of France. What morality there was, was the morality of apperrances, of the side that is turned toward men and not toward God. The rery shamelessness of Congreve is refreshing in that age of sham.

It was impossible that anything truly great, that is, great on the moral and emotional as well as the intellectual side, should be produced by such a generation. But something intellectually great could be and was.

* Morgante, xviii. 115. 
The French mind, always stronger in perceptive and analytic than in imaginative qualities, loving precision, grace, and finesse, prone to attribute an almost magical power to the scientific regulation whether of politics or religion, had brought wit and fincy and the elegant arts of society to as great perfection as was possible by the a priori method. Its ideal in literature was to conjure passion within the magic circle of courtliness, or to combine the appearance of careless ease and gayety of thought with intellectual exactness of statement. The eternal watchfulness of a wit that never slept had made it distrustful of the natural emotions and the unconventional expression of them, and its first question ahout a sentiment was, Will it be safe? about a phrase, Will it pass with the Academy? The effect of its example on English literature would appear chiefly in neatness and facility of turn, in point and epigrammatic compactness of phrase, and these in conveying conventional sentiments and emotions, in appealing to good society rather than to human nature. Its influence would be greatest where its success had been most marked, in what was called moral poetry, whose chosen province was manners, and in which satire, with its arenging scourge, took the place of that profounder art whose office it was to purify, not the manners, but the source of them in the soul, by pity and terror. The mistake of the whole school of French criticism, it seems to me, lay in its tendency to confound what was common with what was vulgar, in a too exclusive deference to authority at the expense of all free movement of the mind.

There are certain defects of taste which correct themselves by their orm extravagance. Langruage, I suspect, is more apt to be reformed by the charm of some master of it, like Milton, than by any amount of precept. The influence of second-rate writers for evil is at best ephem- 
eral, for true style, the joint result of culture and natural aptitude, is always in fashion, as fine manners always are, in whatever clothes. Perhaps some reform was needed when Quarles, who had no mean gift of poesy, could write,

"My passion has no April in her eyes:

I cannot spend in mists; I cannot mizzle;

$\mathrm{My}$ fluent brains are too severe to drizzle

Slight drops." *

Good taste is an excellent thing when it confines itself to its own rightful province of the proprieties, but when it attempts to correct those profound instincts out of whose judgments the higher principles of æesthetics have been formulated, its snccess is a disaster. During the era when the French theory of poetry was supreme, we notice a decline from imagination to fancy, from passion to wit, from metaphor, which fuses image and thought in one, to simile, which sets one beside the other, from the supreme code of the natural sympathies to the parochial by-laws of etiquette. The imagination instinctively Platonizes, and it is the essence of poetry that it should be unconventional, that the soul of it should subordinate the outward parts; while the artificial method proceeds from a principle the reverse of this, making the spirit lackey the form.

Waller preaches up this new doctrine in the epilogue to the "Maid's Tragedy"

"Nor is ' $t$ less strange such mighty wits as those Shouid use a style in tragedy like prose;

Well-sounding verse, where princes tread the stage, Should speak therr virtue and describe their rage."

* Elegic on Doctor Wilson. But if Quarles had been led astray by the vices of Iomne's mamer, he had good company in Herbert and Vaighan. In common with them, too, he liad that Juck of simpleness which is even more delightful than wit. In the same poem he says, -

"Go, glorious soul, and lay thy temples down

In Abram's bosom, in the sacred donon

Of soft eternity." 
That it should be beneath the dignity of princes to speak in anything but rhyme can only be paralleled by Mr. Puff's law that a heroine can go decorously mad only in white satin. Waller, I suppose, though with so loose a thinker one cannot be positive, uses "describe" in its Latin sense of limitation. Fancy Othello or Lear confined to this go-cart! Phillips touches the true point when he says, "And the truth is, the use of measure alone, without any rime at all, would give more scope and liberty both to style and fancy than can possibly be observed in rime." * But let us test Waller's method by an example or two. His monarch made reasonable, thus discourses:-

"Courage our greatest failings does supply, And makes all good, or handsomely we die. Life is a thing of common use; by heaven As well to insects as to monarchs given; But for the crown, ' $t$ is a more sacred thing; I 'll dying lose it, or I 'll live a king.

Come, Diphilus, we must together walk And of a matter of importance talk."

[Exeunt.

Blank verse, where the sentiment is trivial as here, merely removes prose to a proper ideal distance, where it is in keeping with more impassioned parts, but commonplace set to this rocking-horse jog irritates the nerves. There is nothing here to remind us of the older tragic style but the exeunt at the close. Its pithy conciseness and the relief which it brings us from his majesty's prosing give it an almost poetical savor. Aspatia's reflections upon suicide (or "suppressing our breath," as she calls it), in the same play, will make few readers regret that Shakespeare was left to his orn unassisted barbarism when he wrote Hamlet's soliloquy on the same topic :-

"T 'T was in compassion of our woe

That nature first made poisons grow,

* Preface to the Theatrum. 


\section{Tor hopeless wretches such as I \\ Kindly providing means to die: \\ As mothers do their children keep, \\ So Nature feeds and makes us sleep. \\ The indisposed she does invite \\ To go to bed before 't is night."}

Correctness in this case is but a synonyme of monotony, and words are chosen for the number of their syllables, for their rubbishy value to fill-in, instead of being forced upon the poet by the meaning which occupies the mind. Language becomes useful for its diluting properties, rather than as the medium by means of which the thought or fancy precipitate themselves in crystals upon a comnecting thread of purpose. Let us read a few verses from Beaumont and Fletcher, that we may feel fully the differeace between the rude and the reformed styles. This also shall be a speech of Aspatia's. Antiphila, one of her maidens, is working the story of Thesens and Ariatne in tapestry, for the older masters loved a picturesque background and knew the value of fanciful accessaries. Aspatia thinks the face of Ariadne not sad enough :- -

\section{"Do it by me,}

Do it again by me, the lost Aspatia, And you shall find all true but the wild island.

Suppose I stand upon the seabeach now,

Mine arms thus, and my hair blown with the wind,

Wild as that desert; and let all about me

Be teachers of my story. Do my face

(If ever thou hadst feeling of a sorrow)

Thus, thus, Antiphila; strive to make me look

Like sorrow's monument; and the trees about me

Let them be dry and lenfless; let the rocks

Groan with continual surges; and behind me Make all a desolation."

What instinctive felicity of versification! what sobbing breaks and passionate repetitions are here!

We see what the direction of the new tendency was, but it would be an inadequate or a dishonest criticism 
that shuld hold Pope responsible for the narrow compass of the instrument which was his legacy from his immediate predecessors, any more than for the wearisome thrumming-over of his tune by those who came after him and who had caught his technical skill without his genius. The question properly stated is, How much was it possible to make of the material supplied by the age in which he lived? and how much did he make of it? Thus far, among the great English poets who preceded him, we have seen actual life represented by Chaucer, imaginative life by Spenser, ideal life by Shakespeare, the interior life by Milton. But as everything aspires to a rhythmical utterance of itself, so conventional life, itself a new phenomenon, was waiting for its poet. It found or made a most fitting one in Pope. He stands for exactness of intellectual expression, for perfect propriety of phrase (I speak of him at his best), and is a striking instance how much success and permanence of reputation depend on conscientious finish as well as on native endowment. Butler asks, -

\footnotetext{
"Then why should those who pick and choose

The best of all the best compose, And join it by Mosaic art, In graceful order, part to part, To make the whole in beauty suit, Not merit as complete repute As those who, with less art and pain, Can do it with their native brain?"
}

Butler knew very well that precisely what stamps a man as an artist is this power of finding out what is "the best of all the best."

I confess that I come to the treatment of Pope with diffidence. I was brought up in the old superstition that he was the greatest poet that ever lived; and when I came to find that I had instincts of my own, and my mind was brought in contact with the apostles of a more 
esoteric doctrine of peetry, I felt that ardent desire for smashing the idols I had been brought up to worship, without any regard to their artistic beauty, which characterizes youthful zeal. What was it to me that Pope was called a master of style? I felt, as Addison says in his Freeholder when answering an argument in favor of the Pretender because he could speak English and George I. could not, "that I did not wish to be tyrannized over in the best English that ever was spoken." The young demand thoughts that find an echo in their real and not their acquired nature, and care very little about the dress they are put in. It is later that we learn to like the conventional, as we do olives. There was a time when I could not read Pope, but disliked him on principle as old loger Ascham seems to have felt about Italy when he says, "I was once in Italy myself, but I thank (xod my abode there was only nine days."

But Pope fills a very important place in the history of English poetry, and must be studied by every one who would come to a clear knowledge of it. I have since read over every line that Pope ever wrote, and every letter written by or to him, and that more than once. If I have not come to the conclusion that he is the greatest of poets, I believe that I am at least in a condition to allow him every merit that is fairly his. I have said that Pope as a literary man represents precision and grace of expression; but as a poet he represents something more, - nothing less, namely, than one of those eternal controversies of taste which will last as long as the imagination and understanding divide men between them. It is not a matter to be settled by any amount of argument or demonstration. There are born Popists or Wordsworthians, Lockists or Kantists, and there is nothing more to be said of the matter. Wordsworth was not in a condition to do Pope justice. 
A man brought tup in sublime mountain solitudes, and whose nature was a solitude more vast than they, walking an earth which quivered with the throe of the French Revolution, the child of an era of profomnd mental and moral morement, it could not be expected that he should be in sympathy with the poet of artificial life. Noreover, he was the apostle of imagination, and came at a time when the school which Pope founded had degrenerated into a mob of mannerists who wrote with ease, and who with their congenial critics united at once to decry poetry which brought in the dangerous innovation of having a soul in it.

But howerer it may be with poets, it is very certain that a reader is happiest whose mind is broad enough to enjoy the natural school for its nature, and the artificial for its artificiality, provided they be only good of their kind. At any rate, we must allow that the man who can produce one perfect work is cither a great genius or a very lucky one; and so far as we who read are concerned, it is of secondary importance which. And Pope has done this in the "Rape of the Lock." For wit, finey, invention, and keeping, it has never been surpassed. I do not say there is in it poetry of the highest order, or that Pope is a poet whom any one would choose as the companion of his best hours. There is no inspiration in it, no trumpet-call, but for pure entertainment it is ummatched. There are two kinds of genius. The first and highest may be said to speak out of the eternal to the present, and must compel its age to understand $i t$; the second understands its age, and tells it what it wishes to be told. Let us find strength and inspiration in the one, amusement and instruction in the other, and be honestly thankful for both.

The very earliest of Pope's productions give indications of that sense and discretion, as well as wit, which after- 
ward so eminently distinguished him. The facility of expression is remarkable, and we find also that perfect balance of metre, which he afterward carried so far as to be wearisome. His pastorals were written in his sixteenth year, and their publication immediately brought him into notice. The following four verses from his first pastoral are quite characteristic in their antithetic balance :-

"You that, too wise for pride, too good for power, Enjoy the glory to be great no more:

And carrying with you all the world can boast, To all the world illustriously are lost!"

The sentiment is aflected, and reminds one of that future period of Pope's Correspondence with his Friends, when Swift, his heart corroding with disappointed ambition at Dublin, Bolingbroke raising delusive turnips at his farm, and Pope pretending not to feel the lampoons which imbittered his life, played together the solemn farce of affecting indifference to the world by which it would have agonized them to be forgotten, and wrote letters addressed to each other, but really intended for that posterity whose opinion they assumed to despise.

In these pastorals there is an entire want of nature. For example in that on the death of Mrs. Tempest:-

"Her fate is whispered by the gentle breeze

And told in sighs to all the trembling trees;

The trembling trees, in every plain and wood,

Her fate remurmur to the silver flood:

The silver flood, so lately calm, appears

Swelled with new passion, and o'erflows with tears;

The winds and trees and floods her death deplore

Daphne, our grief! our glory now no more!"

All this is as perfectly professional as the mourning of an undertaker. Still worse, Pope materializes and makes too palpably objective that sympathy which our grief forces upon outward nature. Milton, before making the echoes mourn for Lycidas, puts our feelings in 
tune, as it were, and hints at his own imagination as the source of this emotion in inanimate things, -

"But, O the heavy change now thou art gone!"

In "Windsor Forest" we find the same thing again :-

"Here his first lays majestic Denham sung,

There the last numbers flowed from Cowley's tongue;

0 early lost, what tears the river shed

When the sad pomp along his banks was led!

His drooping swans on every note expire,

And on his willows hung each muse's 'yre!"

In the same poem he indulges the absurd conceit that,

"Beasts urged by us, their fellow-beasts pursue,

And learn of man each other to undo";

and in the succeeding verses gives some striking instances of that artificial diction, so inappropriate to poems descriptive of natural objects and ordinary life, which brought verse-making to such a depth of absurdity in the course of the century.

"With slaughtering guns, the unwearied fowler roves

Where frosts have whitened all the naked groves;

Where doves in flocks the leafless trees o'ershade,

And lonely wookcocks haunt the watery glade;

He lifts the tube and levels with his eye,

Straight a short thunder breaks the frozen sky:

Oft as in airy rings they skim the heath,

The clamorous lapwings feel the leaden death;

Oft as the mounting larks their notes prepare,

They fall and leave their little lives in air."

Now one would imagine that the tube of the fowler was a telescope instead of a gun. And think of the larks preparing their notes like a country choir! Yet even here there are admirable lines, -

"Oft as in airy rings they skim the heath,"

"They fall and leave their little lives in air,"

for example.

In Pope's next poem, the "Essay on Criticism," the 
wit and poct become apparent. It is full of clear thoughts, compactly expressed. In this poem, written when Pope was only twenty-one, occur some of those lines which have become proverbial ; such as

"A little learning is a dangerous thing";

"For fools rush in where angels fear to tread";

"True wit is Nature to advantage dressed, What oft was thought, but ne'er so well expressed."

"For each ill author is as bad a friend."

In all of these we notice that terseness in which (regard being had to his especial range of thought) Pope has never been equalled. One camnot help being struck also with the singular discretion which the poem gives evidence of. I do not know where to look for another author in whom it appeared so carly, and, considering the vivacity of his mind and the constantly besetting temptation of his wit, it is still more wonderful. In his boyish correspondence with poor old Wycherley, one would suppose him to be the man and Wycherley the youth. Pope's understanding was no less vigorous (when not the dupe of his nerres) than his fancy was lightsome and sprightly.

I eome now to what in itself would be enough to have immortalized him as a poet, the "Rape of the Lock," in which, indeed, he appears more purely as poet than in any other of his productions. Elsewhere he has shown more force, more wit, more reach of thought, but nowhere such a truly artistic combination of elegance and fancy. His genius has here found its true direction, and the very same artificiality, which in his pastorals was umpleasing, heightens the effect, and adds to the general keeping. As truly as Shakespeare is the poet of man, as God made him, dealing with great passions and innate motives, so truly is Pope the poet of society, 
the delineator of manners, the exposer of those motives which may be called acquired, whose spring is in institutions and habits of purely worldly origin.

The "Rape of the Lock" was written in Pope's twentyfourth year, and the machinery of the Sylphs was added at the suggestion of Dr. Garth, - a circumstance for which we can feel a more unmixed gratitude to him than for writing the "Dispensary." The idea was taken from that entertaining book "The Count de Gabalis," in which Fouquè afterward found the hint for his "Undine"; but the little sprites as they appear in the poem are purely the creation of Pope's fancy.

The theory of the poem is excellent. The heroic is out of the question in fine society. It is perfectly true that almost every door we pass in the street closes upon its private tragedy, but the moment a great passion enters a man he passes at once out of the artificial into the human. So long as he continues artificial, the sublime is a conscious absurdity to him. The mock-heroic then is the only way in which the petty actions and sufferings of the fine world can be epically treated, and the contrast continually suggested with subjects of larger scope and more dignified treatment, makes no small part of the pleasure and sharpens the point of the wit. The invocation is admirable:-

"Say, what strange motive, Goddess, could compel,

A well-bred lord to assault a gentle belle?

$\mathrm{O}$ say what stranger cause, yet unexplored,

Could make a gentle belle reject a lord?"

The keynote of the poem is here struck, and we are able to put ourselves in tune with it. It is not a parody of the heroic style, but only a setting it in satirical juxtaposition with cares and events and modes of thought with which it is in comical antipathy, and while it is not degraded, they are shown in their triviality. The 
"clouded cane," as compared with the Homeric spear, indicates the difference of scale, the lower plane of emotions and passions. The opening of the action, too, is equally good :-

"Sol through white curtains shot a timorous ray, And oped those eyes that must eclipse the day, Now lapdogs give themselves the rousing shake, And sleepless lovers just at twelve awake; Thrice rung the bell, the slipper knocked the ground, And the pressed watch returned a silver sound."

The mythology of the Sylphs is full of the most fanciful wit; indeed, wit infused with fancy is Pope's peculiar merit. The Sylph is addressing Belinda :-

"Know, then, unnumbered spirits round thee fly, The light militia of the lower sky;

These, though unseen, are ever on the wing, Hang o'er the box and hover round the ring. As now your own our beings were of old, And once enclosed in woman's beauteous mould; Think not, when woman's transient breath is fled, That all her vanities at once are dead; Succeeding vanities she still regards, And, though she plays no more, o'erlooks the cards. For when the fair in all their pride expire, To their first elements their souls retire; The sprites of fiery termagants in flame Mount up and take a salamander's name; Soft yielding nymphs to water glide away And sip, with nymphs, their elemental tea; The graver prude sinks downward to a gnome, In search of mischief still on earth to roam; The light coquettes in sylphs aloft repair And sport and flutter in the fields of air."

And the contrivance by which Belinda is awakened is also perfectly in keeping with all the rest of the machin. ery:-

"He said: when Shock, who thought she slept too long, Leaped up and waked his mistress with his tongue; 'T was then, Belinda, if report say true, Thy eyes first opened on a billet-doux." 
Throughout this poem the satiric wit of Pope peeps out in the pleasantest little smiling ways, as where, in describing the toilet-table, he says :-

"Here files of pins extend their shining rows, Puffs, powders, patches, Bibles, billet-doux."

Or when, after the fatal lock has been severed,

"Then flashed the living lightning from her eyes, And screams of horror rend the affirighted skies, Not louder shrieks to pitying Heaven are cast When husbands or when lapdogs breathe their last ;

Or when rich china-vessels, fallen from high, In glittering dust and painted fragments lie!"

And so, when the conflict begins :-

"Now Jove suspends his golden scales in air;

Weighs the men's wits against the ladies' hair;

The doubtful beam long nods from side to side;

At length the wits mount up, the hairs subside."

But more than the wit and fancy, I think, the perfect keeping of the poem deserves admiration. Except a touch of grossness, here and there, there is the most pleasing harmony in all the conceptions and images. The punishments which he assigns to the sylphs who neglect their duty are charmingly appropriate and ingenious :-

" Whatever spirit, careless of his charge,

His post neglects, or leaves the fair at large,

Shall feel sharp vengeance soon o'ertake his sins;

Be stopped in vials or transfixed with pins,

Or plunged in lakes of bitter washes lie,

Or wedged whole ages in a bodkin's eye;

Gums and pomatums shall his flight restrain,

While clogged he beats his silver wings in vain;

Or alum styptics with contracting power,

Shrink his thin essence like a rivelled flower;

Or as Ixion fixed the wretch shall feel

The giddy motion of the whirling wheel,

In fumes of burning chocolate shall glow,

And tremble at the sea that froths below!" 
The speech of Thalestris, too, with its droll climax, is equally good:-

"Methinks already I your tears survey,

Already hear the horrid things they say,

Already see you a degraded toast,

And all your honor in a whisper lost!

How shall I then your helpless fame defend?

'T' will then be infamy to seem your friend!

And shall this prize, the inestimable prize,

Exposed through crystal to the gazing eyes,

And heightened by the diamond's circling rays,

On that rapacious hand forever blaze?

Sooner shall grass in Hydepark Circus grow,

And wits take lodging in the sound of Bow,

Sooner let earth, air, sea, in chaos fall,

Men, monkeys, lapdogs, parrots, perish all!"

So also Belinda's account of the morning omens :-

"'T was this the morning omens seemed to tell;

Thrice from my trembling hand the patch-box fell;

The tottering china shook without a wind;

Nay, Poll sat mute, and Shock was most unkind."

The idea of the goddess of Spleen, and of her palace, where

"The dreaded East is all the wind that blows,"

was a very happy one. In short, the whole poem more truly deserves the name of a creation than anything Pope ever wrote. The action is confined to a world of his own, the supernatural agency is wholly of his own contrivance, and nothing is allowed to overstep the limitations of the subject. It ranks by itself as one of the purest works of human fancy; whether that fancy be strictly poctical or not is another matter. If we compare it with the "Midsummer-night's Dream," an uncomfortable doubt is suggested. The perfection of form in the "Rape of the Lock" is to me conclusive evidence that in it the natural genius of Pope found fuller and freer expression than in any other of his poems. The others are aggregates of brilliant passages rather than harmonious wholes. 
It is a droll illustration of the inconsistencies of human nature, a more profound satire than Pope himself ever wrote, that his fume should chrefly rest upon the "Essay on Man." It has been praised and admired by men of the most opposite beliefs, and men of no belıef at all. Bishops and free-thinkers have met here on a common ground of sympathetic approval. And, indeed, there is no particular farth in it. It is a droll medley of inconsistent opinions. It proves only two things beyond a question, - that Pope was not a great thinker; and that wherever he found a thought, no matter what, he could express it so tersely, so clearly, and with such smoothness of versification as to give it an everlasting currency. Hobbes's unwieldy Leviathan, left stranded there on the shore of the last age, and nauseous with the stench of its selfishness, - from this Pope distilled a fragrant oil with which to fill the brilliant lamps of his philosophy, - lamps like those in the tombs of alchemists, that go out the moment the healthy air is let in upon them. The only positive doctrines in the poem are the selfishness of Hobbes set to music, and the Pantheism of Spinoza brought down from mysticism to commonplace. Nothing can be more absurd than many of the dogmas taught in this "Essay on Man." For example, Pope affirms explicitly that instinct is something better than reason :-

"See him from Nature rising slow to art,

To copy instinct then was reason's part;

Thus, then, to man the voice of nature spake; -

Go, from the creatures thy instructions take;

Learn from the beasts what food the thickets yield;

Learn from the birds the physic of the field;

The arts of building from the bee receive;

Learn of the mole to plough, the worm to weare;

Learn of the little nautilus to sail,

Spread the thin oar, or catch the driving gale."

I say nothing of the quiet way in which the general 
term "nature" is substituted for God, but how unutterably void of reasonableness is the theory that Nature would have left her highest product, man, destitute of that instinct with which she had endowed her other creatures! As if reason were not the most sublimated form of instinct. The accuracy on which Pope prided himself, and for which he is commended, was not accuracy of thought so much as of expression. And he cannot always even claim this merit, but only that of correct rhyme, as in one of the passiges I have already quoted from the "Rape of the Lock" he talks of casting shrieks to heaven, - a performance of some difficulty, except when cast is needed to rhyme with last.

But the supposition is that in the "Essay on Man" Pope did not himself know what he was writing. He was only the condenser and epigrammatizer of Bolingbroke, - a very fitting St. John for such a gospel. Or, if he did know, we can account for the contradictions by supposing that he threw in some of the commonplace moralities to conceal his real drift. Johmson asserts that Bolinghroke in private laughed at Pope's having been made the monthpiece of opinions which he did not hold. But this is hardly probable when we consider the relations between them. It is giving Pope altogether too little credit for intelligence to suppose that he did not understand the principles of his intimate friend. The caution with which he at first concealed the authorship would argue that he had doubts as to the reception of the poem. When it was attacked on the score of infidelity, he gladly accepted Warburton's championship, and assumed whatever pious interpretation he contrived to thrust upon it. The beginning of the poem is familiar to everybody :-

"Awake, my St. John, leave all meaner things To low ambition and the pride of kings; 
Let us (since life can little more supply Than just to look about us and to die) Expatiate free $o^{\prime} e r$ all this scene of man, A mighty maze, - but not without a plan ";

To expatiate o'er a mighty maze is rather loose writing; but the last verse, as it stood in the original editions, was,

"A mighty maze of walks without a plan";

and perhaps this came nearer Pope's real opinion than the rerse he substituted for it. Warburton is careful not to mention this variation in his notes. The poem is everywhere as remarkable for its confusion of logic as it often is for ease of verse and grace of expression. An instance of both occurs in a passage frequently quoted : -

"Heaven from all creatures hides the book of fate;

All but the page prescribed, their present state;

From brutes what men, from men what spirits know,

Or who would suffer being here below?

The lamb thy riot dooms to bleed to-day,

Had he thy reason, would he skip and play?

Pleased to the last, he crops the flowery food,

And licks the hand just raised to shed his blood.

0 , blindness to the future kindly given

That each may fill the circle meant by heaven!

Who sees with equal eye, as God of all,

A hero perish or a sparrow fall,

Atoms or systems into ruin hurled,

And now a bubble burst, and now a world!"

Now, if "heaven from all creatures hides the book of fate," why should not the lamb "skip and play," if he had the reason of man? Why, because he would then be able to read the book of fate. But if man himself cannot, why, then, could the lamb with the reason of man? For, if the lamb had the reason of man, the book of fate would still be hidden, so far as himself was concerned. If the inferences we can draw from appearances are equivalent to a knowledge of destiny, the knowing enough to take an umbrella in cloudy weather 
might be called so. There is a manifest confusion between what we know about ourselves and about other people; the whole point of the passage being that we are always mercifully blinded to our own future, however much reason we may possess. There is also inaccuracy as well as inelegance in saying,

\section{"Heaven,}

Who sees with equal eye, as God of all, A hero perish or a sparrow fall."

To the last verse Warburton, desirous of reconciling his author with Scripture, appends a note referring to Matthew x. 29 : "Are not two sparrows sold for one farthing? and one of them shall not fall to the ground without your Father." It would not have been safe to have referred to the thirty-first verse: "Fear ye not, therefore, ye are of more value than many sparrows."

To my feeling, one of the most beautiful passages in the whole poem is that fimiliar one :-

"Lo, the poor Indian whose untutored mind Sees God in clouds, or hears him in the wind, His soul proud science never taught to stray Far as the solar walk or milky way:

Yet simple Nature to his hope has given Behind the cloud-topt hill a humbler heaven; Some safer world in depth of woods embraced, Some happier island in the watery waste, Where slaves once more their native land behold, No fiends torment, no Christians thirst for gold. To be contents his natural desire, He asks no angel's wing, no seraph's fire, But thinks, admitted to that equal sky, His faithful dog shall bear him company."

But this comes in as a corollary to what went just before :-

"Hope springs eternal in the human breast, Man never is but always to be blest; The soul, uneasy, and confined from home, Rests and expatiates in a life to come." 
Then follows immediately the passage about the poor Indian, who, after all, it seems, is contented with merely being, and whose soul, therefore, is an exception to the general rule. And what have the "solar walk" (as he calls it) and "milky way" to do with the affair? Does our hope of hearen depend on our knowledge of astronomy? Or does he mean that science and faith are necessarily hostile? And, after being told that it is the "untutored mind" of the savage which "sees God in clouds and hears him in the wind," we are rather surprised to find that the lesson the poet intends to teach is that
"All are but parts of one stupendous whole, Whose body Nature is, and God the soul.
That, changed through all, and yet in all the same, Great in the earth, as in the ethereal frame, Warms in the sun, refreshes in the breeze, Glows in the stars, and blossoms in the trees."

So that we are no better off than the untutored Indian, after the poet has tutored us. Dr. Warburton makes a rather lame attempt to ward off the charge of Spinozism from this last passage. He would have found it harder to show that the acknowledgment of any divine revelation would not overturn the greater part of its teachings. If Pope intended by his poem all that the bishop takes for granted in his commentary, we must deny him what is usually claimed as his first merit,-clearness. If he did not, we grant him clearness as a writer at the expense of sincerity as a man. Perhaps a more charitable solution of the difficulty would be, that Pope's precision of thought was no match for the fluency of his verse.

Lord Byron goes so far as to say, in speaking of Pope, that he who executes the best, no matter what his department, will rank the highest. I think there are enough indications in these letters of Byron's, however, that they were written rather more ayainst Wordsworth 
than for Pope. The rule he lays down would make Voltaire a greater poet, in some respects, than Shakespeare. Byron cites Petrarch as an example; yet if Petrarch had put nothing more into his sonnets than execution, there are plenty of Italian someteers who would be his match. But, in point of fact, the department chooses the man and not the man the department, and it has a great deal to do with our estimate of him. Is the department of Milton no higher than that of Butler? Byron took especial care not to write in the style he commended. But I think Pope has received quite as much credit in respect even of exccution as he deserves. Surely execution is not confined to versification alone. What can be worse than this?

". At length Erasmus, that great, injured name, (The glory of the priesthood and the shame,) Stemmed the wild torrent of a barbarous age, And drove those holy vandals off the stage."

It would have been hard for Pope to have found a prettier piece of confusion in any of the small authors he laughed at than this image of a great, injured name stemming a torrent and driving vandals off the stage. And in the following verses the image is helplessly confused :-

"Kind self-conceit to some her glass applies, Which no one looks in with another's eyes, But, as the flatterer or dependant paint, Beholds himself a patriot, chief, or saint."

The use of the word "applies" is perfectly un-English; and it seems that people who look in this remarkable glass see their pictures and not their reflections. Often, also, when Pope attempts the sublime, his epithets become curiously unpoetical, as where he says, in the Dunciad,

"As, one by one, at dread Medea's strain,

The sickening stars fade off the ethereal plain." 
And not seldom he is satisfied with the music of the verse without much regard to fitness of imagery ; in the "Essay on Man," for example :-

"Passions, like elements, though born to fight,

Yet, mixed and softened, in his work unite;

These ' $t$ is enough to temper and employ;

But what composes man can man destroy?

Suffice that Reason keep to Nature's road,

Subject, compound them, follow her and God.

Love, Hope, and Joy, fair Pleasure's smiling train,

Hate, Fear, and Grief, the family of Pain,

These, mixed with Art, and to due bounds confined,

Make and maintain the balance of the mind."

Here reason is represented as an apothecary compuind: ing pills of "pleasure's smiling train" and the "family of pain." And in the Moral Essays,

"Know God and Nature only are the same;

In man the judgment shoots at flying game,

A bird of passage, gone as soon as found,

Now in the moon, perhaps, now under ground."

The "judgment shooting at flying game" is an odd image enough ; but I think a bird of passage, now in the moon and now under ground, could be found nowhere - out of Goldsmith's Natural History, perhaps. An epigrammatic expression will also tempt him into saying something without basis in truth, as where he ranks together "Macedonia's madman and the Swede," and says that neither of them "looked forward farther than his nose," a slang phrase which may apply well enough to Charles XII., but certainly not to the pupil of Aristotle, who showed himself capable of a large political forethought. So, too, the rhyme, if correct, is a sufficient apology for want of propriety in phrase, as where he makes "Socrates bleed."

But it is in his Moral Essays and parts of his Satires that Pope deserves the praise which he himself do sired : 


\begin{abstract}
"Happily to steer
From grave to gay, from lively to severe, Correct with spirit, eloquent with ease, Intent to reason, or polite to please."
\end{abstract}

Here Pope must be allowed to have established a style of his own, in which he is without a rival. One can open upon wit and epigram at any page.

"Behold, if Fortune or a mistress frowns, Some plunge in business, other shave their crowns; To ease the soul of one oppressive weight, This quits an empire, that embroils a state; The same adust complexion has impelled, Charles to the convent, Philip to the field."

Indeed, I think one gets a little tired of the invariable this set off by the inevitable that, and wishes antithesis would let him have a little quiet now and then. In the first couplet, too, the conditional "frown" would have been more elegant. But taken as detached passages, how admirably the different characters are drawn, so admirably that half the rerses have become proverbial. This of Addison will bear reading again :-

"Peace to all such: but were there one whose fires

True genius kindles and fair fame inspires;

Blest with each talent and each art to please, And born to write, converse, and live with ease;

Should such a man, too fond to rulc alone, Bear like the Turk no brother near the throne, View him with scornful yet with jealous eyes, And hate for arts that caused himself to rise, Damn with faint praise, assent with civil leer, And, without sneering, teach the rest to sneer; Willing to wound and yet afraid to strike, Just hint a fault and hesitate dislike, Alike reserved to blame or to commend, A timorous foe and a suspicious friend; Dreading e'en fools, by flatterers besieged, And so obliging that he ne'er obliged; Like Cato give his little Senate laws, And sit attentive to his own applause, While wits and templars every sentence rasse, And wonder with a foolish face of praise; - 
Who but must laugh if such a man there be?

Who would not weep if Atticus were he?"

With the exception of the somewhat technical image in the second verse of Fame blowing the fire of genius, which too much puts us in mind of the frontispieces of the day, surely nothing better of its kind was ever written. How applicable it was to Addison I shall consider in another place. As an accurate intellectual observer and describer of personal weaknesses, Pope stands by himself in English verse.

In his epistle on the characters of women, no one who has ever known a noble woman, nay, I should almost say no one who ever had a mother or sister, will find much to please him. The climax of his praise rather degrades than elevates.
" $O$, blest in temper, whose unclouded ray
Can make to-morrow cheerful as to-day, She who can love a sister's charms, or hear Sighs for a daughter with unwounded ear, She who ne'er answers till a husband cools, Or, if she rules him, never shows she rules, Charms by accepting, by submitting sways, Yet has her humor most when she obeys;
Lets fops or fortune fly which way they will, Disdains all loss of tickets or codille, Spleen, vapors, or smallpox, above them all And mistress of herself, though china fall."

'The last line is very witty and pointed, - but consider what an ideal of womanly nobleness he must have had, who praises his heroine for not being jealous of her daughter. Addison, in commending Pope's "Essay on Criticism," says, speaking of us "who live in the latter ages of the world": "We have little else to do left us but to represent the common sense of mankind, in more strong, more beautiful, or more uncommon lights." I think he has here touched exactly the point of Pope's merit, and, in doing so, tacitly excludes him from the 
position of poet, in the highest sense. Take two of Jeremy 'Taylor's prose sentences about the Countess of Carbery, the lady in Miiton's "Comus": "The religion of this excellent lady was of another constitution : it took root downward in humility, and brought forth fruit upward in the substantial graces of a Christian, in charity and justice, in chastity and modesty, in fair friendships and sweetness of society. . . . And though she had the greatest judgment, and the greatest experience of things and persons I ever yet knew in a person of her youth and sex and circumstances, yet, as if she knew nothing of it, she had the meanest opinion of herself, and like a fiir taper, when she shined to all the room, yet round about her station she had cast a shadow and a cloud, and she shined to everybody but herself." This is poetry, though not in rerse. The plays of the elder dramatists are not without examples of weak and vile women, but they are not without noble ones either. Take these verses of Chapman, for example :-

"Let no man value at a little price

A virtuous woman's counsel: her winged spirit

Is feathered oftentimes with noble words

And, like her beauty, ravishing and pure;

The weaker body, still the stronger soul.

0 , what a treasure is a virtuous wife,

Discreet and loving. Not one gift on earth

Makes a man's life so nighly bound to heaven.

She gives him double forces to endure

And to enjoy, being one with him,

Feeling his joys and griefs with equal sense:

If he fetch sighs, she draws her breath as short;

If he lament, she melts horself in tears;

If he be glad, she triumphs; if he stir,

She moves his way, in all things his sweet ape,

Himself divinely varied without change.

All store without her leaves a man but poor,

And with her poverty is exceeding store."

Pope in the character I have read was drawing his ideal woman, for he says at the end that she shall be his 
muse. The sentiments are those of a bourgeois and of the back parlor, more than of the poet and the muse's bower. A man's mind is known by the company it keeps.

Now it is very possible that the women of Pope's time were as bad as they could be; but if frod made poets for anything, it was to keep alive the traditions of the pure, the holy, and the beautiful. I grant the inquence of the age, but there is a sense in which the poet is of no age, and Beauty, driven from every other home, will never be an outcast and a wanderer, while there is a poet's nature left, will never fail of the tribute at least of a song. It seems to me that Pope had a sense of the neat rather than of the beautiful. His nature delighted more in detecting the blemish than in enjoying the charm.

However great his merit in expression, I think it impossible that a true poet could have written such a satire as the Dunciad, which is even nastier than it is witty. It is filthy eren in a filthy age, and Swift himself could not have gone beyond some parts of it. One's mind needs to be sprinkled with some disinfecting fluid after reading it. I do not remember that any other poet ever made porerty a crime. And it is wholly without discrimination. De Foe is set in the pillory forever; and George Wither, the author of that charming poem, "Fair Virtue," classed among the dunces. And was it not in this age that loose Dick Steele paid his wife the finest compliment ever paid to woman, when he said "that to love her was a liberal education"?

Even in the "Rape of the Lock," the fancy is that of a wit rather than of a poet. It might not be just to compare his Sylphs with the Fairies of Shakespeare; but contrast the kind of fancy shown in the poem with that of Drayton's Nymphidia, for example I will 
give one stanza of it, describing the palace of the Fairy:-

"The walls of spider's legs were made,

Well mortised, and finely laid;

(He was the master of his trade

It curiously that builded:)

The vindows of the eyes of cats,

And, for the roof, instead of slats

'T is covered with the skins of bats,

With moonshine that are gilded。"

In the last line the eye and fancy of a poet are recog. nized.

Personally we know more about Pope than about any of our poets. He kept no secrets about himself. If he did not let the cat out of the hag, he always contrived to give her tail a wrench so that we might know she was there. In spite of the savageness of his satires, his natural disposition seems to have been an amiable one, and his character as an author was as jurely factitious as his style. Dr. Johnson appears to have suspected his sincerity; but artifice more than insincerity lay at the basis of his eharacter. I think that there was very little real malice in him, and that his "evil was wronght from want of thought." When Dennis was old and poos, he wrote a prologue for a play to be acted for his benefit. Except Addison, he numbered among his friends the most illustrious men of his time.

The correspondence of Pope is, on the whole, less interesting than that of any other eminent English poet, except that of Southey, and their letters have the same fault of being labored compositions. Southey's are, on the whole, the more agreable of the two, for they inspire one (as Pope's certainly do not) with a sincere respect for the character of the writer. Pope's are altogether too full of the proclamation of his own virtues to be pleasant reading. It is plain that they 
were mostly addressed to the public, perhaps even to posterity. But letters, however carefully drilled to be circumspect, are sure to blab, and those of Pope leave in the reader's mind an unpleasant feeling of circumspection, - of an attempt to look as an eminent literary character should rather than as the man really was. They have the unnatural constraint of a man in full dress sitting for his portrait and endeavoring to look his best. We never catch him, if he can help it, at unawares. Among all Pope's correspondents, Swift shows in the most dignified and, one is tempted to say, the most amiable light. It is creditable to the Dean that the letters which Pope addressed to him are by far the most simple and straightforward of any that he wrote. No sham could encounter those terrible eyes in Dublin without wincing. I think, on the whole, that a revision of judgment would substitute "discomforting conscious. ness of the public " for "insincerity " in judging Pope's character by his letters. He could not shake off the habits of the author, and never, or almost never, in prose, acquired that knack of seeming carelessness that makes Walpole's elaborate compositions such agreeable reading. Pope would seem to have kept a commonplace-book of phrases proper to this or that occasion; and he transfers a compliment, a fine moral sentiment, nay, even sometimes a burst of passionate ardor, from one correspondent to another, with the most cold-blooded impartiality. Were it not for this curious economy of his, no one could read his letters to Lady Wortley Montague without a conviction that they were written by a lover. Indeed, I think nothing short of the spretoe injuria formae will account for (though it will not excuse) the savage vindictiveness he felt and showed towards her. It may be suspected also that the bitterness of caste added gall to his resentment. His enemy wore 
that impenetrable armor of superior rank which rendered her indifference to his shafts the more provoking that it was unaffected. Even for us his satire loses its sting when we reflect that it is not in human nature for a woman to have had two such utterly irreconcilable characters as those of Lady Mary before and after her quarrel with the poet. In any view of Pope's conduct in this affair, there is an ill savor in his attempting to degrado a woman whom he had once made sacred with his love. Spenser touches the right chord when he says of the Rosalind who had rejected him,

"Not, then, to her, that scornéd thing so base, But to myself the blame, that lookt so high; Yet so much grace let her vouchsafe to grant To simple swain, sith her I may not love, Yet that I may her honor paravant

And praise her worth, though far my wit above; Such grace shall be some guerdon of the grief And long affliction which I have endured."

In his correspondence with Aaron Hill, Pope, pushed to the wall, appears positively mean. He vainly endeavors to show that his personalities had all been written in the interests of literature and morality, and from no selfish motive. But it is hard to believe that Theobald would have been deemed worthy of his disgustful pre-eminence but for the manifest superiority of his edition of Shakespeare, or that Addison would have been so adroitly disfigured unless through wounded selflove. It is easy to conceive the resentful shame which Pope must have felt when Addison so almost contemptuously disavowed all complicity in his volunteer defence of Cato in a brutal assault on Dennis. Pope had done a mean thing to propitiate a man whose critical judgment he dreaded; and the great man, instead of thanking him, had resented his interference as impertinent. In the whole portrait of Atticus one cannot help feeling 
that Pope's satire is not founded on knowledge, but rather on what his own sensitive suspicion divined of the opinions of one whose expressed preferences in poetry implied a condemnation of the very grounds of the satirist's own popularity. We shall not so easily give up the purest and most dignified figure of that somewhat vulgar generation, who ranks with Sidney and Spenser, as one of the few perfect gentlemen in our literary annals. A man who could command the unswerving loyalty of honest and impulsive Dick Steele could not have been a coward or a backbiter. The only justification alleged by Pope was of the flimsiest kind, namely, that Addison regretted the introduction of the sylphs in the second edition of the "Rape of the Lock," saying that the poem was merum sal before. Let any one ask himself how he likes an author's emendations of any poem to which his ear had adapted itself in its former shape, and he will hardly think it needful to charge Addison with any mean motive for his conservatism in this matter. One or two of Pope's letters are so good as to make us regret that he did not oftener don the dressinggown and slippers in his correspondence. One in particular, to Lord Burlington, describing a journey on horseback to Oxford with Lintot the bookseller, is full of a lightsome humor worthy of Cowper, almost worthy of Gray.

Joseph Warton, in summing up at the end of his essay on the genius and writings of Pope, says that the largest part of his works "is of the didactic, moral, and satiric ; and, consequently, not of the most poetic species of poetry; whence it is manifest that good sense and judgment were his characteristical excellences rather than fancy and invention." It is plain that in any strict definition there can be only one kind of poetry, and that what Warton really meant to say was that Pope 
was not a poet at all. This, I think, is shown by what Johnson says in his "Life of Pope," though he does not name Warton. The dispute on this point went on with occasional lulls for more than a half-century after Warton's death. It was renewed with peculiar acrimony when the Rer. W. L. Bowles diffused and confused Warton's critical opinions in his own peculiarly helpless way in editing a new edition of Pope in 1806. Bowles entirely mistook the functions of an editor, and maladroitly entangled his judgment of the poetry with his estimate of the author's character.* Thirteen years later, Campbell, in his "Specimens," controverted Mr. Bowles's estimate of Pope's character and position, both as man and poet. Mr. Bowles replied in a letter to Campbell on what he called "the invariable principles of poetry." This letter was in turn somewhat sharply criticised by Gilchrist in the Quarterly Reriew. Mr. Bowles made an angry and unmannerly retort, among other things charging Gilchrist with the crime of being a tradesman's son, whereupon the affair became what they call on the frontier a free fight, in which Gilchrist, Roscoe, the elder Disraeli, and Byron took part with equal relish, though with various fortune. The last shot, in what had grown into a thirty years' war, between the partisans of what was called the Old School of poetry and those of the New, was fired by Bowles in 1826. Bowles, in losing his temper, lost also what little logic he had, and though, in a vague way, asthetically right, contrived always to be argumentatively wrong. Anger made worse confusion in a brain never very clear, and he had neither the

* Bowles's Sonnets, welluigh forgotten now, did more than his controversial writings for the cause he adrocated. Their influence upon the coming generation was great (greater than we can well account for) and beneficial. Coleridge tells us that he made forty copies of them while at Christ's Hospital. Wordsworth's prefaces first made imagination the true test of poetry, in its more modern sense. But thoy drew little notice till later. 
scholarship nor the critical facuity for a vigorous exposition of his own thesis. Never was wilder hitting than his, and he laid himself open to dreadful punishment, especially from Byron, whose two letters are masterpieces of polemic prose. Bowles most happily exemplified in his own pamphlets what was really the turning-point of the whole controversy (though all the combatants more or less lost sight of it or never saw it), namely, that without clearness and terseness there could be no good writing, whether in prose or verse; in other words that, while precision of phrase presupposes lucidity of thought, yet good writing is an art as well as a gift. Byron alone saw clearly that here was the true knot of the question, though, as his object was mainly mischief, he was not careful to loosen it. The sincerity of Byron's admira tion of Pope has been, it seems to me, too hastily doubted. What he admired in him was that patience in careful finish which he felt to be wanting in himself and in most of his contemporaries. Pope's assailants went so far as to make a defect of what, rightly considered, was a distinguished merit, though the amount of it was exaggerated. The weak point in the case was that his nicety concerned itself wholly about the phrase, leaving the thought to be as faulty as it would, and that it seldom extended beyond the couplet, often not beyond a single verse. His serious poetry, therefore, at its best, is a succession of loosely strung epigrams, and no poet more often than he makes the second line of the couplet a mere trainbearer to the first. His more ambitious works may be defined as careless thinking carefully versified. Lessing was one of the first to see this, and accordingly he tells us that " his great, I will not say greatest, merit lay in what we call the mechanic of poetry." * Lessing,

* Briefe die neneste Litteratur betreffend, 1759, II. Brief. See also his more elaborate criticism of the "Essay on Man" (Pope ein Metaphysiker), 1755. 
with his usual insight, parenthetically qualifies his statement ; for where Pope, as in the "Rape of the Lock," found a subject exactly level with his genius, he was able to make what, taken for all in all, is the most perfect poem in the language.

It will hardly be questioned that the man who writes what is still piquant and rememberable, a century and a quarter after his death, was a man of genius. But there are two modes of uttering such things as cleave to the memory of mankind. They may be said or sung. I do not think that Pope's verse anywhere sings, but it should seem that the abiding presence of fancy in his best work forbids his exclusion from the rank of poet. The atmosphere in which he habitually dwelt was an essentially prosaic one, the language habitual to him was that of conversation and society, so that he lacked the help of that fresher dialect which seems like inspiration in the elder poets. His range of associations was of that narrow kind which is always vulgar, whether it be found in the village or the court. Certainly he has not the force and majesty of Dryden in his better moods, but he has a grace, a finesse, an art of being pungent, a sensitiveness to impressions, that would incline us to rank him with Voltaire (whom in many ways he so much resembles), as an author with whom the gift of writing was primary, and that of verse secondary. No other poet that I remember ever wrote prose which is so purely prose as his ; and yet, in any impartial criticism, the "Rape of the Lock" sets him even as a poet far above many men more largely endowed with poetic feeling and insight than he.

A great deal must be allowed to Pope for the age in which he lived, and not a little, I think, for the influence of Swift. In his own province he still stands unapproachably alone. If to be the greatest satirist of individual 
men, rather than of human nature, if to be the highest expression which the life of the court and the ball-room has ever found in verse, if to have added more phrases to our language than any other but Shakespeare, if to have charmed four generations make a man a great poet, - then he is one. He was the chief founder of an artificial style of writing, which in his hands was living and powerful, because he used it to express artificial modes of thinking and an artificial state of society. Measured by any high standard of imagination, he will be found wanting; tried by any test of wit, he is unrivalled. 
$3477-2 x$ 



LIBRARY OF CONGRESS 